\title{
Pilot domeincompetenties HBO-monitor 2007
}

Citation for published version (APA):

Allen, J. P., \& Ramaekers, G. W. M. (2008). Pilot domeincompetenties HBO-monitor 2007. ROA. ROA

Technical Reports No. 004 https://doi.org/10.26481/umarot.2008004

Document status and date:

Published: 01/01/2008

DOI:

10.26481/umarot.2008004

Document Version:

Publisher's PDF, also known as Version of record

\section{Please check the document version of this publication:}

- A submitted manuscript is the version of the article upon submission and before peer-review. There can be important differences between the submitted version and the official published version of record.

People interested in the research are advised to contact the author for the final version of the publication, or visit the DOI to the publisher's website.

- The final author version and the galley proof are versions of the publication after peer review.

- The final published version features the final layout of the paper including the volume, issue and page numbers.

Link to publication

\footnotetext{
General rights rights.

- You may freely distribute the URL identifying the publication in the public portal. please follow below link for the End User Agreement:

www.umlib.nl/taverne-license

Take down policy

If you believe that this document breaches copyright please contact us at:

repository@maastrichtuniversity.nl

providing details and we will investigate your claim.
}

Copyright and moral rights for the publications made accessible in the public portal are retained by the authors and/or other copyright owners and it is a condition of accessing publications that users recognise and abide by the legal requirements associated with these

- Users may download and print one copy of any publication from the public portal for the purpose of private study or research.

- You may not further distribute the material or use it for any profit-making activity or commercial gain

If the publication is distributed under the terms of Article $25 \mathrm{fa}$ of the Dutch Copyright Act, indicated by the "Taverne" license above, 


\title{
Pilot domeincompetenties HBO-Monitor 2007
}

\author{
Jim Allen
}

Ger Ramaekers

ROA-TR-2008/4

december 2008

Researchcentrum voor

Onderwijs en Arbeidsmarkt

Postbus 616

6200 MD Maastricht

E-mail: secretary@roa.unimaas.nl

Internet: http://www.roa.unimaas.nl

Universiteit Maastricht

Faculteit der Economische Wetenschappen en Bedrijfskunde 
ISBN 978-90-5321-468-8

Sec08.139 


\section{Inhoud}

Bladzijde

$1 \quad$ Inleiding

2 Analyse van domeincompetenties

2.1 Gemiddelde scores en spreiding

2.2 Algemene versus domeinspecifieke formulering van vakkennis

2.3 Voorspellende validiteit 12

2.4 Item non-respons

4 Appendix 1: Steekproeflijst domeincompetenties HBO-Monitor 2007

5 Appendix 2: Standaard competentie-instrument HBO-Monitor 2007

6 Appendix 3: Beschrijvende tabellen van algemene competenties in de pilot 30

6.1 Vereist niveau in huidige functie van algemene competenties

7 Appendix 4: Beschrijvende tabellen van domeincompetenties in de pilot

7.1 Economics

7.2 Commerce

7.3 Business Administration

7.4 Communications

7.5 Law

7.6 Information and Communication Technology 



\section{Inleiding}

In 2006 is op verzoek van de HBO-raad aan een steekproef van afgestudeerden van de sector economie en het domein ICT een lijst met domeinspecifieke competenties voorgelegd. Dit ter vervanging van de lijst generieke competenties die sinds een aantal jaren voor de HBO-Monitor wordt gebruikt (zie: Appendix 2). De omvang van de steekproef in 2006 bedroeg 10\%. Over de resultaten van de 2006 steekproef is aan de HBO-raad gerapporteerd in een notitie, getiteld Resultaten 10\% steekproef domeincompetenties HBO-Monitor 2006.

Op verzoek van de HBO-raad is in meting 2007 de steekproef dusdanig uitgebreid om niet alleen verschillen tussen domeinen, maar ook verschillen tussen opleidingen zichtbaar te kunnen maken. Daarom is in de HBO-Monitor 2007 aan een 1/3 steekproef van afgestudeerden van de sector economie en het domein ICT opnieuw een lijst met (vereenvoudigd geformuleerde) domeinspecifieke competenties voorgelegd (zie: Appendix 1).

\subsubsection{Bepaling steekproefomvang}

Meting 2007 bevatte aanmeldingen voor 40 opleidingen in de sector heo en het domein ICT. Bij een aselecte steekproefomvang van $1 / 3$ zouden van deze 40 opleidingen (uitgaande van een respons van $40 \%$, een aandeel van betaald werkenden $\operatorname{van} 70 \%$ van de respondenten en rekening houdend met item-nonrespons):

- 16 opleidingen te klein zijn, ook als de domeinsteekproef $100 \%$ zou zijn;

- 15 opleidingen voldoende van omvang zijn (ten minste 20 respondenten);

- 9 opleidingen een probleem zijn. Bij een verhoging van de steekproefgrootte zou zich hier het probleem voordoen dat de itemrespons bij de reguliere competenties te klein zou worden om voor een opleiding landelijke cijfers te kunnen presenteren. Dit is een probleem bij de rapportage aan de scholen.

Kortom, een naar opleidingsgrootte gestratificeerde steekproef zou het probleem van de kleine aantallen niet oplossen. Daarom is gekozen voor een overall aselecte 
steekproef van 1/3 om in ieder geval voor zoveel mogelijk grotere opleidingen voldoende aantallen te hebben (soms zelfs wellicht om verschillen tussen scholen binnen een opleiding zichtbaar te maken), en over hele profielen toch iets over domeincompetenties te kunnen zeggen (op basis van een naar opleiding representatieve steekproef). Daarbij komt het volgende. Indien de steekproef wat betreft de domeincompetenties niet aselect getrokken was (maar de kleine opleidingen integraal meegenomen waren), zou dit hebben betekend dat de kleine opleidingen niet in de reguliere competentielijst zouden zijn vertegenwoordigd. Dit zou als gevolg hebben dat voor het heo en het domein ICT de resultaten m.b.t. de reguliere competentielijst niet representatief zouden zijn geweest.

Tabel 1.1 bevat een overzicht van de aantallen afgestudeerden per domein.

Tabel 1.1

Omvang van de steekproef

\begin{tabular}{|c|c|c|c|c|c|c|}
\hline & \multicolumn{2}{|c|}{ Niet in steekproef } & \multicolumn{2}{|c|}{ In steekproef } & \multicolumn{2}{|c|}{ Totaal } \\
\hline & $\mathrm{N}$ & $\%$ & $\mathrm{~N}$ & $\%$ & $\mathrm{~N}$ & $\%$ \\
\hline HEO Economics & 619 & 13 & 262 & 15 & 881 & 14 \\
\hline HEO Commerce & 803 & 17 & 379 & 22 & 1182 & 19 \\
\hline HEO Business Administration & 1601 & 35 & 741 & 42 & 2342 & 37 \\
\hline HEO Communications & 619 & 13 & 283 & 16 & 902 & 14 \\
\hline HEO Law & 187 & 4 & 10 & 1 & 197 & 3 \\
\hline HEO Information and Communication Technology & 799 & 17 & 69 & 4 & 868 & 14 \\
\hline Totaal & 4628 & 100.0 & 1744 & 100.0 & 6372 & 100.0 \\
\hline
\end{tabular}

\section{Onderzoeksinstrument}

Het domeinspecifieke instrument (zie: Appendix 1) bestaat uit een algemeen deel (gebaseerd op de Dublin-descriptoren) en een domeinspecifiek deel (overgenomen van de Informatiebank Domeincompetenties van de HBO-raad). Het domeinspecifieke deel kent 6 varianten voor achtereenvolgens de domeinen Economics, Commerce, Business Administration, Communications, Law en Information and Communication Technology.

Voor iedere competentie (zowel algemeen als domeinspecifiek) is aan de afgestudeerden gevraagd om aan te geven: 
- (indien zij werken) het niveau dat vereist is in de huidige functie (op een 5puntschaal van $1=$ matig $\mathrm{t} / \mathrm{m} 5=$ uitmuntend)

- hoe goed de hbo-opleiding hen heeft voorbereid (op een 5-puntschaal met als antwoordmogelijkheden: volstrekt onvoldoende, onvoldoende, voldoende, goed, zeer goed)

De resultaten m.b.t. de kwaliteit van de voorbereiding door het hbo hebben betrekking op alle afgestudeerden in de steekproef, dus ook op degenen zonder betaald werk. De resultaten m.b.t. het vereiste niveau van de algemene competenties in Appendix 3 hebben betrekking op afgestudeerden die werkzaam zijn in functies op hbo-niveau, en de resultaten m.b.t. het vereiste niveau van de domeinspecifieke competenties in Appendix 4 hebben betrekking op afgestudeerden die in hun kerndomein werken, d.w.z. in een functie die qua vereist opleidingsniveau én vereiste opleidingsrichting aansluit bij de gevolgde hbo-opleiding. Opgemerkt zij dat het aantal afgestudeerden die de vragen m.b.t. het vereiste niveau hebben ingevuld duidelijk lager ligt dan bij de vragen m.b.t. de voorbereiding door het hbo. Dit komt omdat:

- sommige afgestudeerden geen betaald werk verrichten, bijvoorbeeld omdat zij verder onderwijs volgen (85\% van de respondenten in de steekproef verricht betaald werk);

- of omdat zij onder hun opleidingsniveau en/of buiten hun opleidingsrichting werken (de volgende tabel geeft hiervan een beeld).

Tabel $\mathbf{1 . 2}$

Aansluiting opleiding-werk

\begin{tabular}{lcc}
\hline Werk sluit aan op: & N & $\%$ \\
\hline - opleidingsniveau + opleidingsrichting & 805 & 57 \\
- alleen opleidingsniveau & 330 & 23 \\
- alleen opleidingsrichting & 117 & 8 \\
- noch opleidingsniveau, noch opleidingsrichting & 163 & 12 \\
& & 100,0 \\
Totaal & 1415 & \\
\hline
\end{tabular}


Het bovenstaande laat onverlet dat er ook een aantal afgestudeerden is dat de vragen m.b.t. de voorbereiding door het hbo ten onrechte niet heeft ingevuld (voor een analyse van de item non-respons wordt verwezen naar hoofdstuk 2).

\section{Analyse van domeincompetenties}

Dit hoofdstuk bevat een verslag van de analyse van het domeinspecifieke instrument in de 2007 steekproef. Om het verslag overzichtelijk te houden, wordt niet gerapporteerd op het niveau van de afzonderlijke items (dat zijn bij elkaar zo'n 40 tot 50 items), maar worden gemiddelden per domein (of zelfs alle domeinen samen) gepresenteerd. Bovendien zullen de domeingemiddelden over alle items naar verwachting minder grillig zijn dan de uitkomsten per item. Waar mogelijk en relevant worden de uitkomsten van de steekproef vergeleken met de uitkomsten volgens de reguliere hbo-vragenlijst. Voor de beschrijvende resultaten op het niveau van de afzonderlijke items wordt verwezen naar Appendix 3 (algemene competentie-items) en Appendix 4 (domeinspecifieke competentie-items).

\subsection{Gemiddelde scores en spreiding}

\subsubsection{Gemiddelde scores}

Gemiddelde scores vereist niveau van competenties

Om te beginnen worden de gemiddelde scores op het vereiste competentieniveau berekend. Figuur 2.1 bevat de gemiddelde score van werkende afgestudeerden op het vereiste niveau van algemene- en domeincompetenties over alle 6 domeinen samen $^{1}$, afgezet tegen de gemiddelde score van afgestudeerden in dezelfde domeinen die niet in de steekproef zaten (en die dus de reguliere hbo-vragenlijst hebben ingevuld).

1. Bij de domeincompetenties is dit dus voor ieder domein het gemiddelde niveau over alle items en over alle respondenten berekend. 
Figuur 2.1

Gemiddelde score op vereist competentieniveau

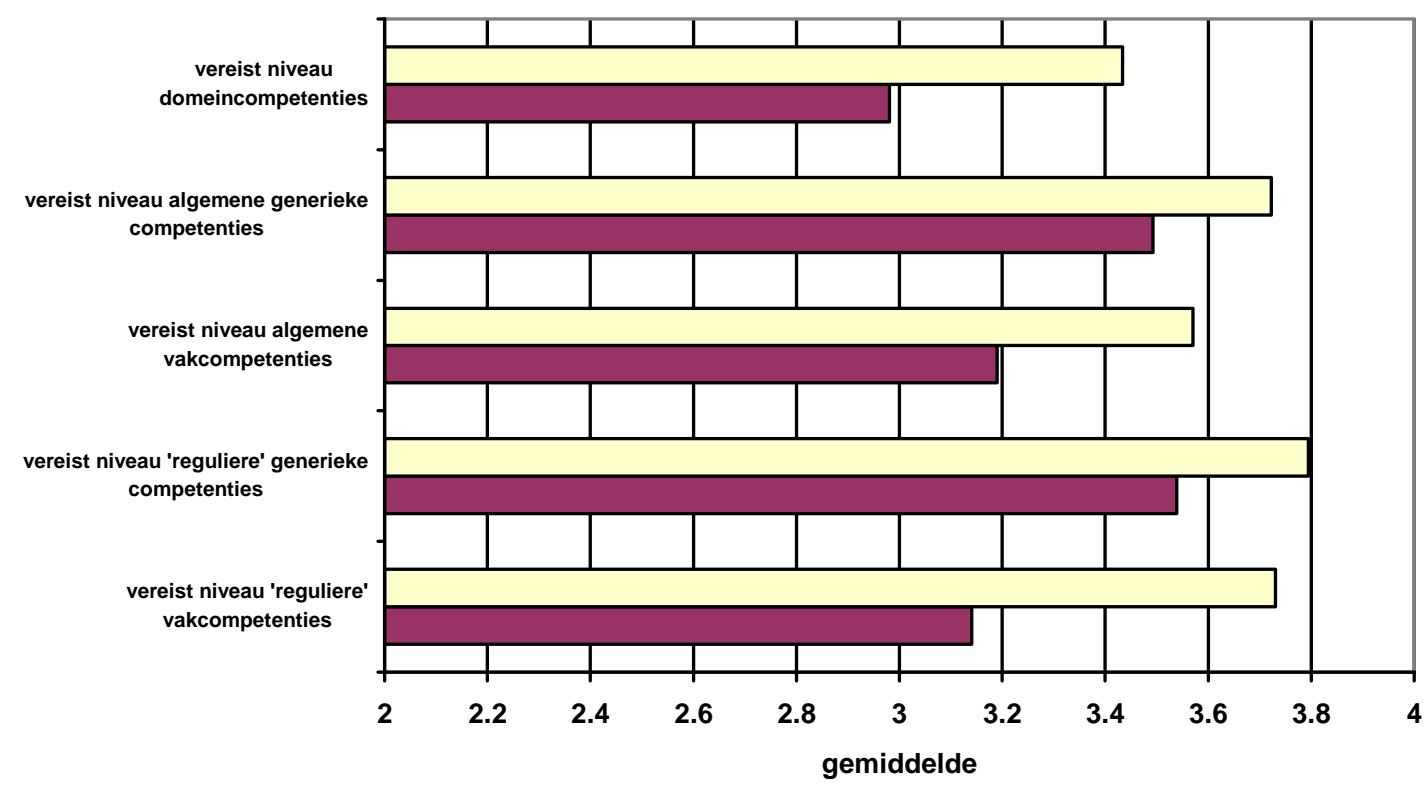

$\square$ werk buiten kerndomein $\square$ werk binnen kerndomein

Bij zowel de algemene competenties in de steekproeflijst als de items in de reguliere hbo-vragenlijst kan een onderscheid worden gemaakt tussen generieke items en items die toch vakspecifiek zijn (bijvoorbeeld omdat ze de formulering "in uw vakgebied" bevatten).

- Bij de algemene competenties in de nieuwe lijst (zie Appendix 1) zijn de eerste vier items vakspecifiek (algemene vakcompetenties), en de overige 5 items generiek (algemene generieke competenties).

- Bij de reguliere hbo-vragenlijst (zie Appendix 2) zijn alleen items a en c vakspecifiek ('reguliere' vakcompetenties), terwijl de rest generiek is ('reguliere' generieke competenties). 


\section{Indeling van competenties}

\section{Steekproeflijst (zie Appendix 1)}

1 Domeincompetenties (opleidingsspecifieke competenties)

2 Algemene generieke competenties:

- Vermogen om relevante informatie te verzamelen en te interpreteren

- Vermogen om argumenten aan te voeren en te verdiepen

- Vermogen om een afgewogen oordeel te vormen

- Vermogen om aan anderen duidelijk te maken wat u bedoelt

- Vermogen om uw kennis op een substantieel hoger niveau te brengen

3 Algemene vakcompetenties:

- Kennis en inzicht van uw eigen vakgebied

- Vermogen om de laatste ontwikkelingen in uw vakgebied eigen te maken

- Vermogen om uw vakkennis en -inzicht op professionele wijze toe te passen

- Vermogen om problemen op uw vakgebied op te lossen

\section{Reguliere lijst (zie Appendix 2)}

1 'Reguliere vakcompetenties'

- Kennis van uw eigen vakgebied

- Vermogen om uw vakkennis in de praktijk toe te passen

2 'Reguliere generieke competenties'

- Kennis van uw eigen vakgebied

Vermogen om:

- uw vakkennis in de praktijk toe te passen

- informatie- \& communicatietechnologie te gebruiken

- in buitenlandse talen te communiceren

- informatie te vergaren

- problemen en kansen te signaleren

- verbanden te leggen tussen verschillende zaken

- hoofd- van bijzaken te onderscheiden

- logisch te redeneren

- conform budget, planning of richtlijnen te werken 
- onder druk goed te functioneren

- knopen door te hakken

- nieuwe ideeën en oplossingen te bedenken

- nieuwe dingen te leren

- aan anderen duidelijk te maken wat $\mathrm{u}$ bedoelt

- productief met anderen samen te werken

- capaciteiten van anderen aan te spreken

- zelfstandig de werkzaamheden uit te voeren

Bereidheid om:

- uw nek uit te steken

- ideeën van uzelf en anderen ter discussie te stellen

- op te komen voor uw eigen standpunt

- begrip te tonen voor andere standpunten

Omdat het aannemelijk is dat domeincompetenties vooral nodig zullen zijn wanneer mensen binnen hun eigen kerndomein werkzaam zijn (d.w.z. in banen op minimaal hbo-niveau waarvoor hun eigen of een verwante opleidingsrichting werd vereist), zijn de scores apart gepresenteerd voor werkenden binnen en buiten hun eigen kerndomein.

Uit figuur 2.1 blijkt duidelijk dat vooral binnen het kerndomein een beroep wordt gedaan op een tamelijk hoog niveau aan competenties. Tegen de verwachting in blijkt dit het minst het geval bij de domeincompetenties. Er zijn verschillende verklaringen denkbaar voor deze uitkomst. Het feit dat een niet te verwaarlozen deel van de mensen die binnen hun kerndomein werkzaam zijn aangeven dat een domeincompetentie niet relevant is, kan een teken zijn dat er wellicht met de items zelf iets aan de hand is. Wellicht sluit de lijst domeincompetenties niet goed aan met wat in de praktijk is vereist, of worden per individu sommige competenties wel en anderen niet vereist. Het is ook niet uit te sluiten dat de items zelf slecht worden begrepen (de toelichtende omschrijving bij sommige items is ook wel erg uitgebreid). 


\section{Gemiddelde scores voorbereiding door hbo-opleiding}

Figuur 2.2 toont de gemiddelde scores op het oordeel over de kwaliteit van de voorbereiding door de hbo-opleiding. Deze vraag wijkt af van de reguliere lijst, waarin het eigen competentieniveau werd gevraagd. Hoewel het om twee verschillende vragen gaat, is een vergelijking van de antwoorden interessant. In tegenstelling tot het vereiste niveau is de vraag over de voorbereiding door de opleiding c.q. het eigen competentieniveau van toepassing op alle afgestudeerden, dus niet alleen degenen met betaald werk. Hoewel een verband met het kerndomein minder vanzelfsprekend is dan bij het vereiste niveau, is een uitsplitsing interessant. Wellicht hebben afgestudeerden die door de opleiding beter zijn voorbereid, meer kansen om een baan te bemachtigen, vooral binnen het eigen kerndomein.

\section{Figuur 2.2}

Gemiddelde score op eigen competentieniveau c.q. voorbereiding door de opleiding

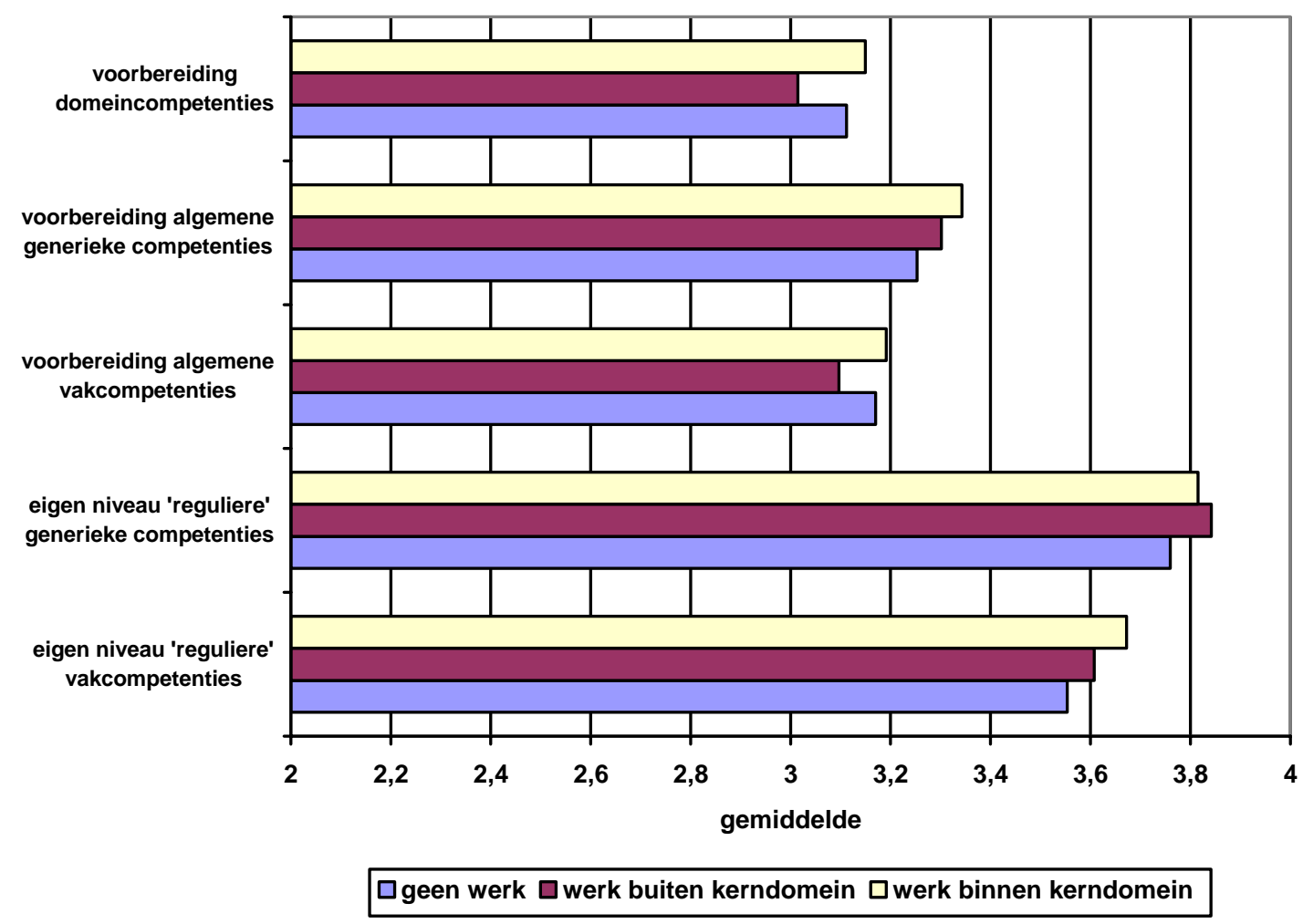

Het meest opvallend aan figuur 2.2 is het verschil tussen de antwoorden op de reguliere lijst en de steekproeflijst. Gezien het feit dat zowel de vragen als de antwoordschalen verschillend zijn, heeft dit echter niet veel te betekenen. Verder blijkt dat men iets positiever is over de generieke dan de vakspecifieke competenties, 
hoewel het verschil bij de steekproef items niet groot is. Er is weinig verschil tussen mensen zonder werk, werkenden binnen hun kerndomein en werkenden buiten hun kerndomein. Opvallend is dat het verschil zich in de verwachte richting manifesteert bij zowel de generieke als vakcompetenties uit de reguliere vragenlijst en bij de domein- en vakcompetenties uit de steekproeflijst, terwijl bij de algemene generieke competenties van de steekproeflijst het verschil in de omgekeerde richting wijst. Maar omdat de verschillen niet groot zijn, lijkt het niet verstandig om te veel gewicht hier aan te hechten.

Figuur 2.3 vergelijkt de gemiddelde scores tussen de domeinen. Bij het vereiste niveau is vooraf geselecteerd op werkenden binnen het eigen kerndomein. Figuur 2.3 laat zien dat er forse verschillen zijn tussen de domeinen wat de vereiste competenties betreft.

\section{Figuur 2.3}

Gemiddelde score op vereist competentieniveau en voorbereiding door de opleiding

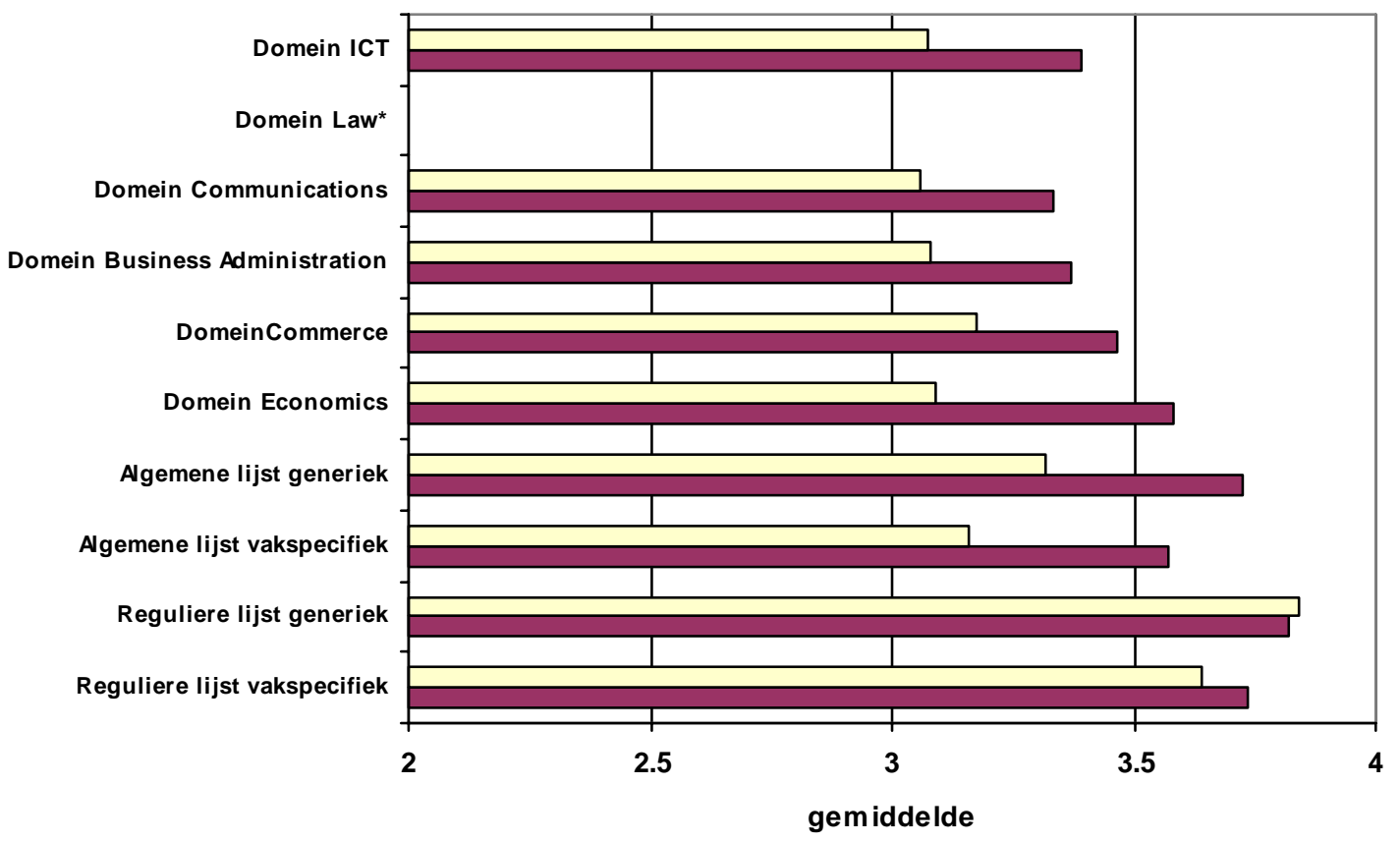

$\square$ vereist niveau (binnen kerndomein) $\square$ voorbereiding door opleiding

\footnotetext{
* Te weinig waarnemingen
} 


\subsubsection{Gemiddelde spreiding}

Als het gaat om de bruikbaarheid van het instrument is het van belang dat het instrument voldoende differentieert tussen afgestudeerden. Ideaal zouden we willen weten of de scores differentiëren tussen instellingen die dezelfde opleiding aanbieden. Daarvoor zijn de aantallen echter te klein. Een beperktere indicatie van de mate van differentiatie is de overal spreiding van de antwoorden. Figuur 2.4 geeft de gemiddelde spreiding (standaarddeviatie) weer per domein, en voor de algemene en reguliere competenties.

\section{Figuur 2.4}

Gemiddelde spreiding op vereist competentieniveau en voorbereiding door de opleiding

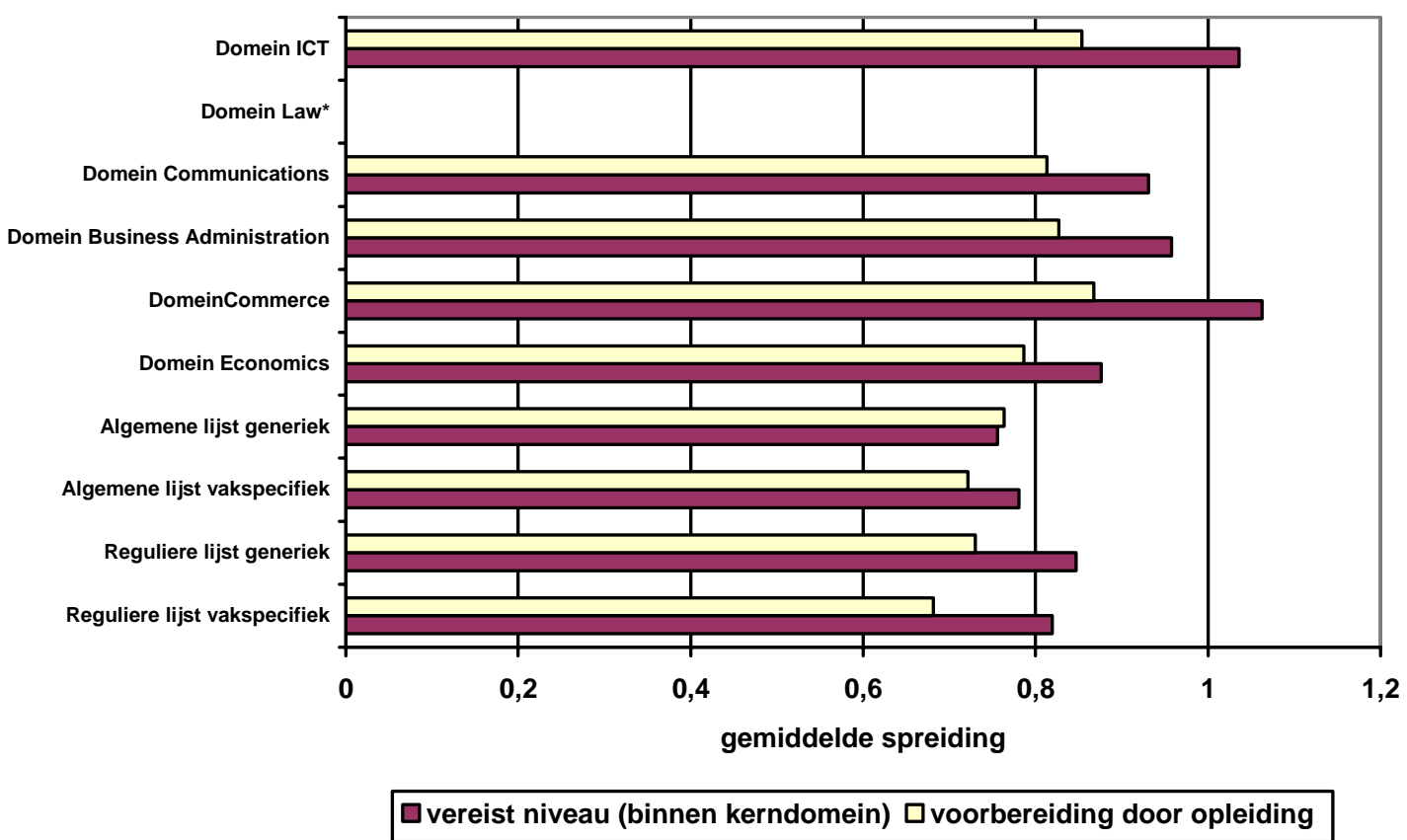

* Te weinig waarnemingen

Over de hele linie is de gemiddelde spreiding iets groter bij de domeincompetenties dan bij de algemene competenties in de steekproef en de competenties in de reguliere hbo-vragenlijst. Dit is enigszins verassend, omdat de spreiding van elk van de domeincompetenties per definitie beperkt is tot het eigen domein, terwijl bij de algemene en reguliere competenties dit over alle 6 domeinen is berekend. $\mathrm{Bij}$ de meeste items ligt de standaarddeviatie tussen de 0,7 en 1,0, wat redelijk hoog is bij een 5-puntsschaal. 


\subsection{Algemene versus domeinspecifieke formulering van vakkennis}

Een belangrijke vraag is de mate waarin het mogelijk is om vakspecifieke competenties door middel van algemeen geformuleerde items te meten. Hoewel deze vraag te complex is om hier in zijn volledigheid te beantwoorden, bieden de data de mogelijkheid om een beperktere versie van deze vraag te analyseren, namelijk de vraag of individuele variantie binnen een domein een vergelijkbare patroon vertoont wanneer we gebruik maken van een algemene formulering als wanneer we domeinspecifieke items hanteren. De eerste competentie in de nieuwe algemene lijst luidt "kennis en inzicht van uw eigen vakgebied". Dit item is min of meer te beschouwen als een samenvatting van de afzonderlijke domeincompetenties. Als het instrument werkt, zouden we een vrij sterke samenhang moeten verwachten. Figuur 2.5 geeft per domein de gemiddelde correlatie tussen het algemeen geformuleerde item en de domeincompetenties.

\section{Figuur 2.5}

Gemiddelde correlatie tussen domeinspecifieke items en het algemeen geformuleerde item

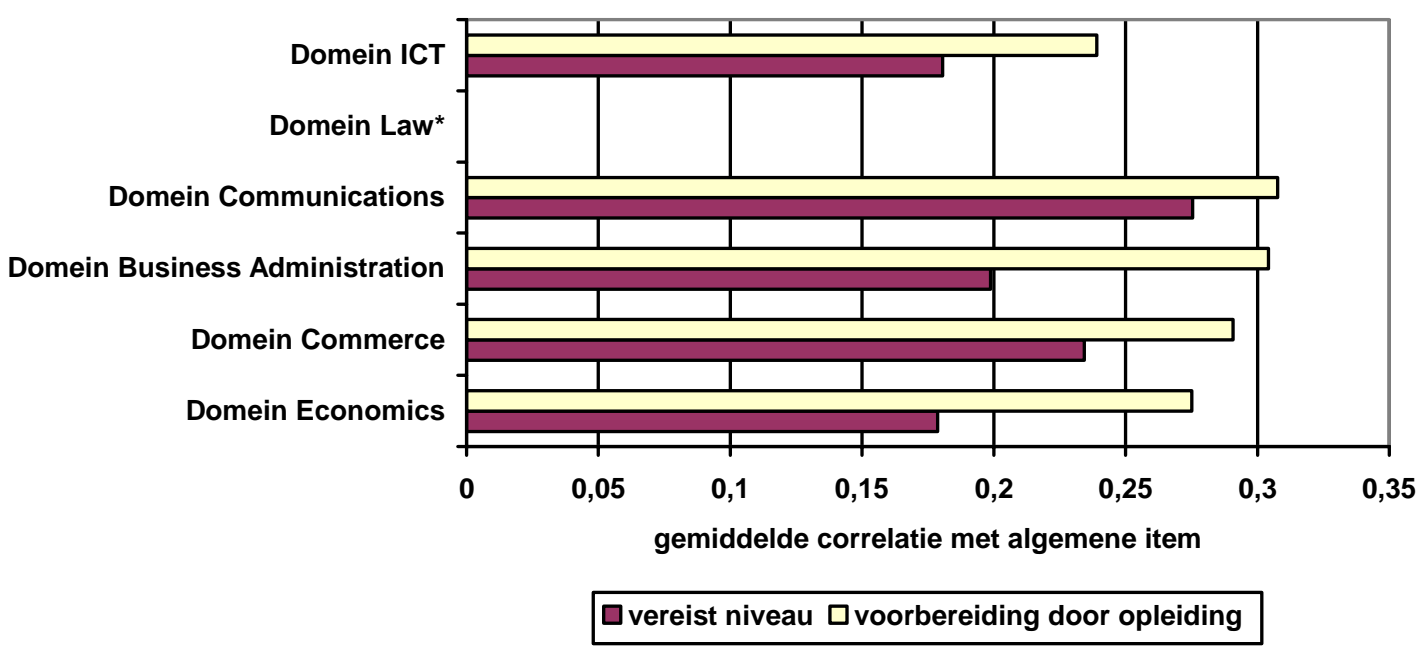

* Te weinig waarnemingen

Bij het vereiste niveau bestaat voor alle domeinen gemiddeld een relatie tussen de algemeen geformuleerde en domeinspecifiek geformuleerde meting van vakcompetenties. Echter, zelf de sterkste correlatie - voor het domein Communications - is 
niet echt sterk te noemen. Uit figuur 2.5 blijkt dat de correlaties iets sterker zijn voor de voorbereiding door de opleiding.

\subsection{Voorspellende validiteit}

\subsubsection{Gemiddelde correlaties}

Om de voorspellende validiteit van de items te toetsen, is eest nagegaan in hoeverre de scores covariëren met uitkomsten waarvan op theoretische gronden mag worden verwacht dat ze met de scores zouden moeten samenhangen. Voor de voorbereiding door de opleiding zijn de relevante indicatoren: de algemene oordelen van respondenten over de mate waarin de opleiding een goede basis vormde om op de arbeidsmarkt te starten en de mate waarin de opleiding een goede basis vormde voor het verder ontwikkelen van kennis en vaardigheden. De gemiddelde correlaties met deze indicatoren staan in figuren 2.6 en 2.7. Per domein worden de gemiddelde correlaties van zowel de algemene als de domeinspecifieke competenties met de twee genoemde indicatoren gepresenteerd. Hoewel het om een iets andere soort indicator gaat die minder direct verband heeft met de twee oordeelvragen, staat ter vergelijking de gemiddelde correlatie met de items in de reguliere vragenlijst voor die respondenten die niet in de steekproef zaten.

De nieuwe algemene competenties correleren het sterkst met de twee oordeelvragen. Ook de domeincompetenties vertonen redelijke correlaties, maar het feit dat deze bijna over de hele linie een stuk(je) lager zijn dan de algemene items is verassend. ${ }^{2}$ Wellicht verdienen de Dublin descriptoren meer krediet dan ze in sommige kringen ontvangen voor wat betreft de mate waarin ze een goed beeld geven van de mate waarin afgestudeerden goed voorbereid zijn op de werkpraktijk. De compe-

2. Er zijn overigens weinig verschillen hierbij tussen de vier (algemeen geformuleerde) vakcompetenties en de generieke competenties in de algemene lijst (steekproeflijst). 
tenties uit de reguliere lijst vertonen gemiddeld niet of nauwelijks een relatie met het oordeel over de opleiding.

\section{Figuur 2.6}

Voorbereiding door de opleiding: gemiddelde correlatie met oordeel over opleiding als basis om te starten

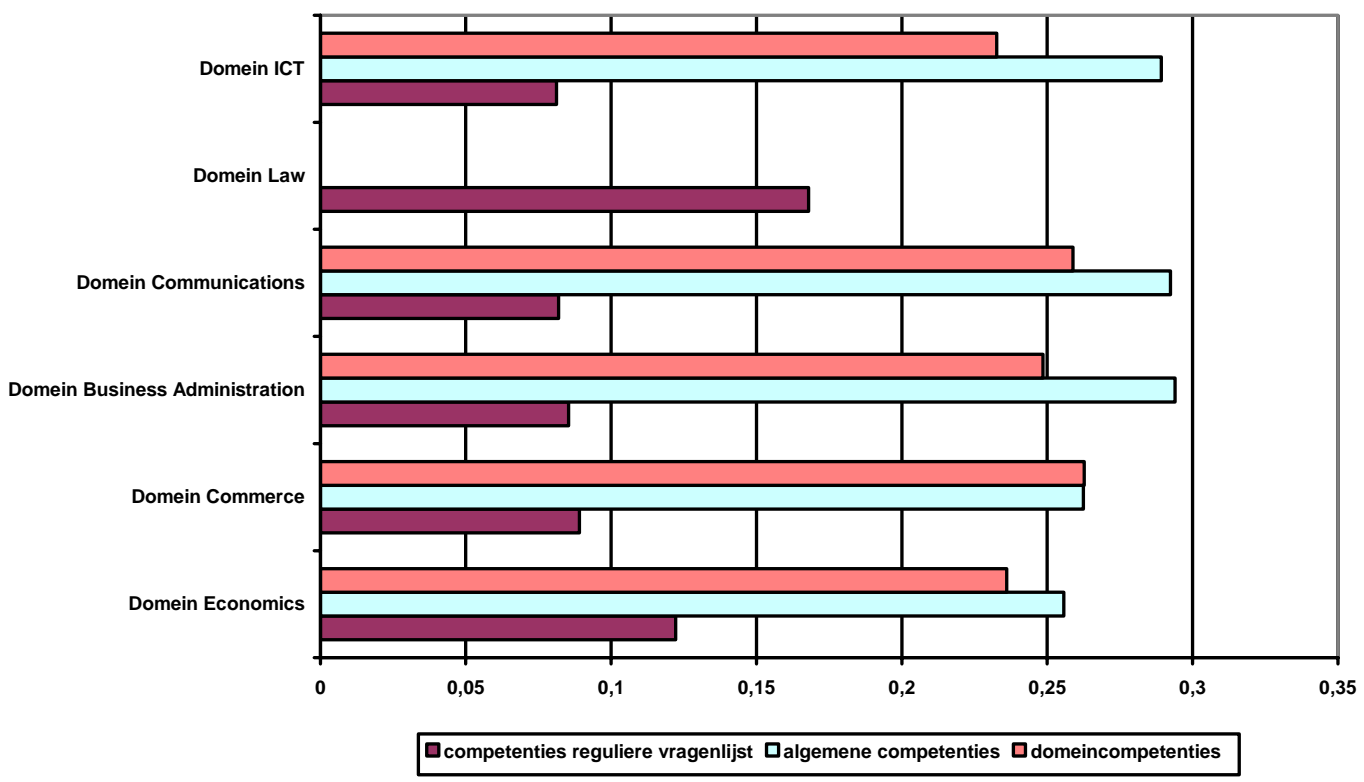

\section{Figuur 2.7}

Voorbereiding door de opleiding: gemiddelde correlatie met oordeel over opleiding als basis om verder te leren

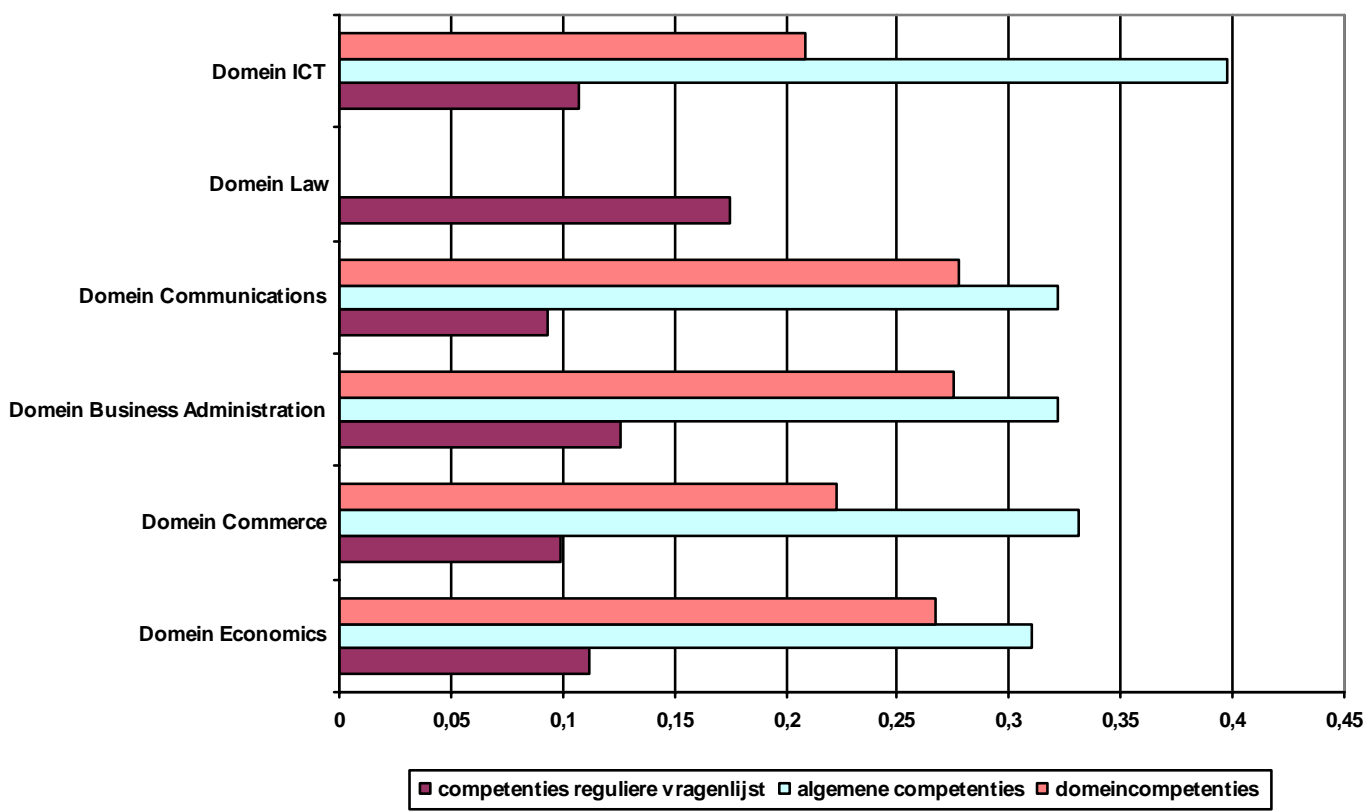

3. Zoals je zou verwachten bij zo'n lange en diverse lijst, zijn er aanzienlijke verschillen per item bij de reguliere vragenlijst. Echter, zelfs de sterkste correlaties van de items uit deze lijst met de oordeelvragen zijn beduidend lager dan die bij de nieuwe lijsten. 
De meest directe indicator van de mate waarin de meting van het vereiste niveau valide is, is de mate waarin afgestudeerden vinden dat hun kennis en vaardigheden worden benut. Immers: hoe hoger het niveau is dat wordt vereist, hoe meer de kennis en vaardigheden van de afgestudeerden benut zouden moeten worden. De gemiddelde correlaties met deze variabele staan in figuur 2.8 .

\section{Figuur 2.8}

Vereist competentieniveau: gemiddelde correlatie met benutting van kennis en vaardigheden

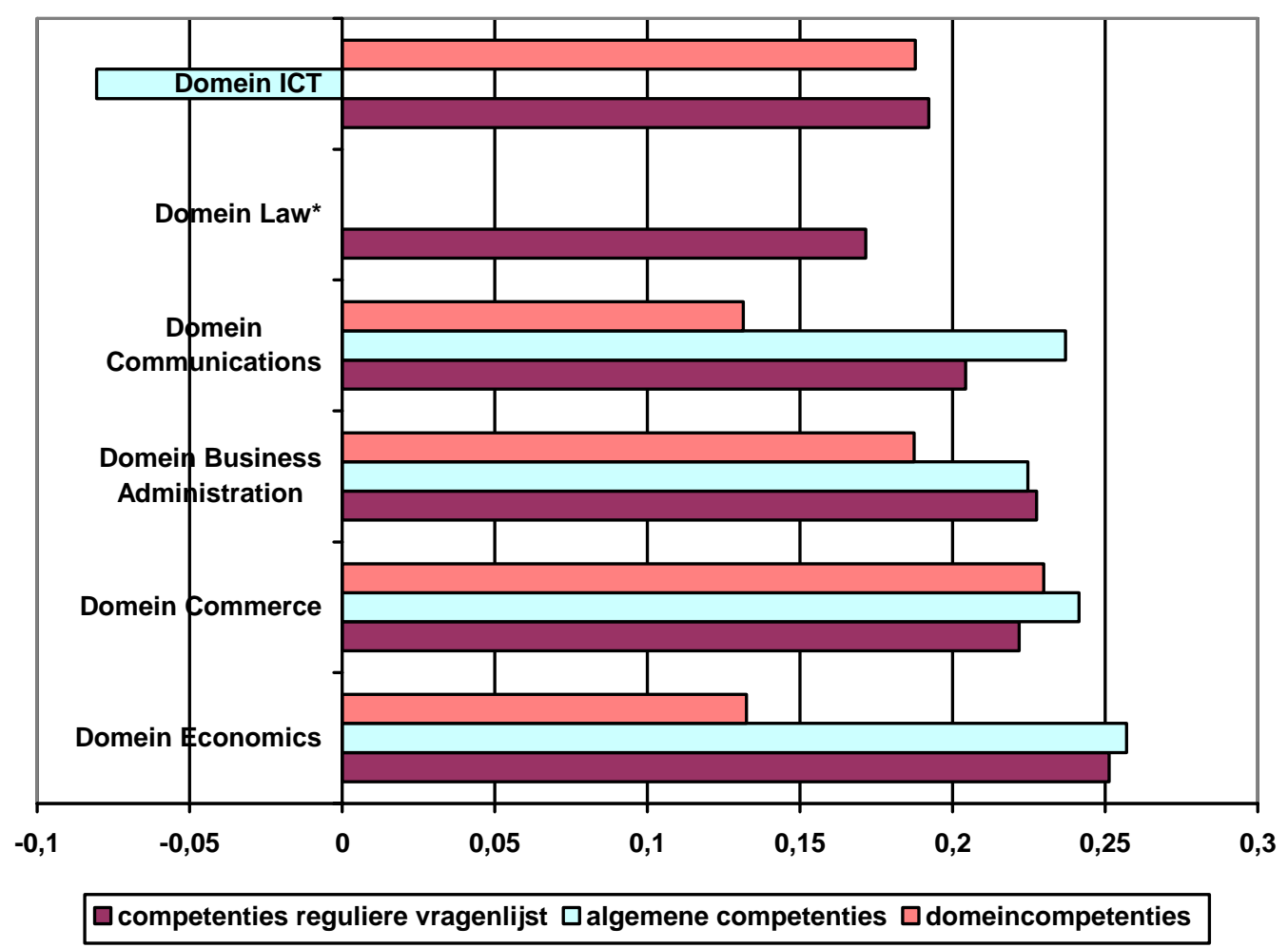

Anders dan bij de voorbereiding door de hbo-opleiding, zijn er niet veel verschillen tussen de drie groepen vereiste competenties in termen van gemiddelde correlaties met benutting. Bij een aantal domeinen zijn de gemiddelde correlaties met algemene competenties vrij laag, en bij het domein ICT is de gemiddelde correlatie met algemene competenties zelfs licht negatief.

\subsubsection{Regressieanalyses}

Om de voorspellende validiteit van de domeincompetenties meer uitgebreid te toetsen, zijn regressieanalyses gedraaid met achtereenvolgens drie afhankelijke vari- 
abelen, namelijk het oordeel over opleiding als basis om te starten op de arbeidsmarkt (tabel 2.1), het oordeel over de opleiding als basis voor het verder ontwikkelen van kennis en vaardigheden (tabel 2.2) en het bruto uurloon ${ }^{4}$ (tabel 2.3).

Bij de eerste twee analyses (opleiding als basis om te starten respectievelijk verder te leren) zijn als voorspellers de mate van voorbereiding op de competenties (voor de reguliere competenties het eigen niveau) gebruikt. Voor de analyses van uurloon zijn als voorspellers zowel de voorbereiding op de competenties (voor de reguliere lijst het eigen niveau) als het vereiste niveau (voor de reguliere competentielijst het evt. surplus) opgenomen. Om het simpel te houden en een vergelijking tussen de competentielijsten te vergemakkelijken, zijn de competenties geclusterd. Hierbij is een onderscheid gemaakt tussen generieke en specifieke competenties. In de kolommen van de volgende drie tabellen staan de drie competentielijsten:

- de domeinspecifieke competentielijsten die per domein verschillend zijn (aangeduid als 'domein');

- de gemeenschappelijke competentielijst die aan de hele steekproef voor de sector economie is voorgelegd (aangeduid als 'sector');

- de reguliere lijst die sinds 2003 aan alle afgestudeerden wordt voorgelegd (aangeduid als 'regulier').

Voor de sectorlijst zijn de eerste 4 competenties als 'specifiek' aangeduid, en de andere 5 als 'generiek'. Voor de reguliere lijst zijn de eerste en derde competentie uit de lijst 'specifiek', en de andere competenties 'generiek'. Omdat de domeinlijst alleen specifieke competenties omvat, is in de modellen 2 en 3 het generieke cluster uit de sectorlijst opnieuw gebruikt. Bij alle analyses zijn er 3 modellen geschat: alleen specifieke competenties (model 1), alleen generieke competenties (model 2), en specifieke + generieke competenties samen (model 3). Model 2 voor de domeinlijst is grijs gemaakt omdat het eigenlijk overbodig is. Het is namelijk in principe gelijk aan model 2 voor de sectorlijst (de uitkomsten verschillen licht vanwege verschillen in item missings). Om de analyses op de reguliere lijst zo goed mogelijk

4. Het bruto uurloon als indicator voor de productieve waarde die op de arbeidsmarkt aan afgestudeerden wordt toegekend. 
vergelijkbaar te maken met de andere twee lijsten, is een steekproef getrokken met ongeveer hetzelfde aantal cases (in de meeste gevallen pakken de aantallen iets kleiner uit, maar dit zal vrijwel niets uitmaken voor de significanties).

\section{Bevindingen uit de regressieanalyses}

Heel kort door de bocht kan worden gesteld dat de steekproeflijsten het beter doen als voorspeller van het oordeel over de opleiding, maar dat de reguliere lijst het beter doet als voorspeller van het uurloon. De eerste uitkomst ligt voor de hand gezien het feit dat het oordeel over de voorbereiding ook een oordeel is over de opleiding. Dat uurloon beter wordt voorspeld door de reguliere lijst is verrassend, en pleit niet voor de nieuwe lijsten.

Er lijken weinig systematische verschillen te zijn tussen de voorspellende kracht van de domein- en sectorlijst, en ook niet tussen de generieke en specifieke competenties. Over de hele linie lijkt het alsof de specifieke items in de sectorlijst het iets beter doen dan de specifieke- en generieke items in de domeinlijst. Er zijn veel uitzonderingen hierop, maar het suggereert dat men in ieder geval met algemeen geformuleerde items, zelfs als het om specifieke competenties gaat, niet slechter af is dan met specifieke items. 
Tabel 2.1

Resultaten OLS-regressieanalyses, afhankelijke variabele oordeel over de opleiding als basis om te starten op de arbeidsmarkt; gestandaardiseerde effecten en adjusted R2

\begin{tabular}{|c|c|c|c|c|}
\hline & & \multicolumn{2}{|c|}{ Competentielijst } & \multirow[b]{2}{*}{$\overline{\text { Regulier }}$} \\
\hline & & Domein & Sector & \\
\hline Model & Domein Economics & & & \\
\hline \multirow[t]{2}{*}{1} & Specifiek & 0,308 & 0,310 & 0,237 \\
\hline & Adj. R2 & 0,090 & 0,092 & 0,052 \\
\hline \multirow[t]{2}{*}{2} & Generiek & 0,326 & 0,321 & 0,191 \\
\hline & Adj. R2 & 0,102 & 0,099 & 0,032 \\
\hline \multirow[t]{5}{*}{3} & Specifiek & $\underline{0,182}$ & $\underline{0,181}$ & $\underline{0,189}$ \\
\hline & Generiek & 0,224 & 0,210 & 0,096 \\
\hline & Adj. R2 & 0,120 & 0,115 & 0,054 \\
\hline & $N=$ & 202 & 205 & 204 \\
\hline & Domein Commerce & & & \\
\hline \multirow[t]{2}{*}{1} & Specifiek & 0,378 & 0,349 & $\underline{0,159}$ \\
\hline & Adj. R2 & 0,140 & 0,119 & 0,021 \\
\hline \multirow[t]{2}{*}{2} & Generiek & 0,319 & 0,351 & 0,158 \\
\hline & Adj. R2 & 0,099 & 0,120 & 0,020 \\
\hline \multirow[t]{5}{*}{3} & Specifiek & 0,290 & 0,207 & 0,098 \\
\hline & Generiek & $\underline{0,156}$ & 0,212 & 0,095 \\
\hline & Adj. R2 & 0,153 & 0,141 & 0,021 \\
\hline & $N=$ & 285 & 291 & 215 \\
\hline & Domein Business Ad & & & \\
\hline \multirow[t]{2}{*}{1} & Specifiek & 0,335 & 0,399 & 0,191 \\
\hline & Adj. R2 & 0,111 & 0,158 & 0,035 \\
\hline \multirow[t]{2}{*}{2} & Generiek & 0,310 & 0,316 & 0,092 \\
\hline & Adj. R2 & 0,094 & 0,098 & 0,007 \\
\hline \multirow[t]{5}{*}{3} & Specifiek & 0,236 & 0,339 & 0,195 \\
\hline & Generiek & 0,180 & 0,090 & $-0,007$ \\
\hline & Adj. R2 & 0,132 & 0,161 & 0,033 \\
\hline & $N=$ & 582 & 595 & 509 \\
\hline & Domein Communica & & & \\
\hline \multirow[t]{2}{*}{1} & Specifiek & 0,345 & 0,467 & 0,226 \\
\hline & Adj. R2 & 0,115 & 0,214 & 0,046 \\
\hline \multirow[t]{2}{*}{2} & Generiek & 0,278 & 0,264 & 0,289 \\
\hline & Adj. R2 & 0,073 & 0,065 & 0,079 \\
\hline \multirow[t]{4}{*}{3} & Specifiek & 0,276 & 0,537 & 0,096 \\
\hline & Generiek & 0,122 & $-0,103$ & 0,236 \\
\hline & Adj. R2 & 0,121 & 0,216 & 0,081 \\
\hline & $\mathrm{N}=$ & 206 & 213 & 203 \\
\hline
\end{tabular}


Tabel 2.2

Resultaten OLS-regressieanalyses, afhankelijke variabele oordeel over de opleiding als basis om kennis en vaardigheden te ontwikkelen; gestandaardiseerde effecten en adjusted R2

\begin{tabular}{|c|c|c|c|c|}
\hline & & \multicolumn{2}{|c|}{ Competentielijst } & \multirow[b]{2}{*}{ Regulier } \\
\hline & & Domein & Sector & \\
\hline Model & Domein Economics & & & \\
\hline \multirow[t]{2}{*}{1} & Specifiek & 0,342 & 0,376 & $\underline{0,168}$ \\
\hline & Adj. R2 & 0,113 & 0,137 & 0,024 \\
\hline \multirow[t]{2}{*}{2} & Generiek & 0,396 & 0,394 & 0,135 \\
\hline & Adj. R2 & 0,152 & 0,151 & 0,013 \\
\hline \multirow[t]{5}{*}{3} & Specifiek & $\underline{0,175}$ & 0,215 & 0,135 \\
\hline & Generiek & 0,297 & 0,263 & 0,067 \\
\hline & Adj. R2 & 0,169 & 0,177 & 0,022 \\
\hline & $\mathrm{N}=$ & 202 & 205 & 204 \\
\hline & Domein Commerce & & & \\
\hline \multirow[t]{2}{*}{1} & Specifiek & 0,332 & 0,430 & 0,229 \\
\hline & Adj. R2 & 0,107 & 0,182 & 0,048 \\
\hline \multirow[t]{2}{*}{2} & Generiek & 0,386 & 0,409 & 0,259 \\
\hline & Adj. R2 & 0,146 & 0,164 & 0,063 \\
\hline \multirow[t]{5}{*}{3} & Specifiek & 0,168 & 0,283 & 0,106 \\
\hline & Generiek & 0,292 & 0,219 & $\underline{0,191}$ \\
\hline & Adj. R2 & 0,163 & 0,205 & 0,065 \\
\hline & $\mathrm{N}=$ & 285 & 292 & 215 \\
\hline & Domein Business Ad & & & \\
\hline \multirow[t]{2}{*}{1} & Specifiek & 0,364 & 0,437 & 0,201 \\
\hline & Adj. R2 & 0,131 & 0,190 & 0,039 \\
\hline \multirow[t]{2}{*}{2} & Generiek & 0,338 & 0,336 & 0,135 \\
\hline & Adj. R2 & 0,113 & 0,111 & 0,016 \\
\hline \multirow[t]{5}{*}{3} & Specifiek & 0,256 & 0,383 & 0,179 \\
\hline & Generiek & 0,197 & 0,082 & 0,043 \\
\hline & Adj. R2 & 0,157 & 0,192 & 0,038 \\
\hline & $\mathrm{N}=$ & 582 & 595 & 509 \\
\hline & Domein Communica & & & \\
\hline \multirow[t]{2}{*}{1} & Specifiek & 0,377 & 0,465 & 0,124 \\
\hline & Adj. R2 & 0,138 & 0,212 & 0,011 \\
\hline \multirow[t]{2}{*}{2} & Generiek & 0,361 & 0,345 & $\underline{0,174}$ \\
\hline & Adj. R2 & 0,126 & 0,115 & 0,026 \\
\hline \multirow[t]{4}{*}{3} & Specifiek & 0,255 & 0,429 & 0,040 \\
\hline & Generiek & 0,217 & 0,053 & 0,152 \\
\hline & Adj. R2 & 0,166 & 0,210 & 0,022 \\
\hline & $\mathrm{N}=$ & 206 & 213 & 203 \\
\hline
\end{tabular}


Tabel 2.3

Resultaten OLS-regressieanalyses, afhankelijke variabele uurloon uit hoofdfunctie; gestandaardiseerde effecten en adjusted $\mathrm{R} 2$

\begin{tabular}{|c|c|c|c|c|}
\hline & & \multicolumn{2}{|c|}{ Competentielijst } & \multirow[b]{2}{*}{ Regulier } \\
\hline & & Domein & Sector & \\
\hline \multirow{4}{*}{$\begin{array}{l}\text { Model } \\
1\end{array}$} & Domein Economics & & & \\
\hline & Specifiek voorbereiding/eigen & 0,084 & $-0,007$ & 0,235 \\
\hline & Specifiek vereist/surplus & 0,110 & 0,093 & $-0,179$ \\
\hline & Adj. R-2 & 0,010 & $-0,003$ & 0,071 \\
\hline \multirow[t]{3}{*}{2} & Generiek voorbereiding/eigen & 0,003 & 0,005 & 0,309 \\
\hline & Generiek vereist/surplus & 0,086 & 0,085 & $-0,164$ \\
\hline & Adj. R-2 & $-0,004$ & $-0,004$ & 0,087 \\
\hline \multirow[t]{7}{*}{3} & Specifiek voorbereiding/eigen & 0,107 & $-0,032$ & 0,115 \\
\hline & Specifiek vereist/surplus & 0,084 & 0,074 & $-0,155$ \\
\hline & Generiek voorbereiding/eigen & $-0,047$ & 0,036 & $\underline{0,239}$ \\
\hline & Generiek vereist/surplus & 0,068 & 0,031 & $-\overline{0,062}$ \\
\hline & Adj. R-2 & 0,001 & $-0,013$ & 0,099 \\
\hline & $\mathrm{N}=$ & 173 & 176 & 154 \\
\hline & Domein Commerce & & & \\
\hline \multirow[t]{3}{*}{1} & Specifiek voorbereiding/eigen & 0,035 & 0,020 & 0,057 \\
\hline & Specifiek vereist/surplus & 0,005 & 0,138 & $-0,242$ \\
\hline & Adj. R-2 & $-0,009$ & 0,012 & 0,045 \\
\hline \multirow[t]{3}{*}{2} & Generiek voorbereiding/eigen & $-0,010$ & $-0,020$ & 0,082 \\
\hline & Generiek vereist/surplus & 0,145 & 0,141 & $\underline{-0,174}$ \\
\hline & Adj. R-2 & 0,010 & 0,008 & $\overline{0,022}$ \\
\hline \multirow[t]{6}{*}{3} & Specifiek voorbereiding/eigen & 0,031 & 0,024 & 0,012 \\
\hline & Specifiek vereist/surplus & $-0,075$ & 0,093 & $-0,250$ \\
\hline & Generiek voorbereiding/eigen & $-0,025$ & $-0,018$ & 0,068 \\
\hline & Generiek vereist/surplus & $\underline{0,178}$ & 0,063 & 0,018 \\
\hline & Adj. R-2 & $\overline{0,004}$ & 0,003 & 0,034 \\
\hline & $N=$ & 202 & 205 & 149 \\
\hline & Domein Business Administration & & & \\
\hline \multirow[t]{3}{*}{1} & Specifiek voorbereiding/eigen & 0,025 & 0,031 & 0,082 \\
\hline & Specifiek vereist/surplus & 0,167 & 0,149 & $-0,112$ \\
\hline & Adj. R-2 & 0,026 & 0,021 & 0,011 \\
\hline \multirow[t]{3}{*}{2} & Generiek voorbereiding/eigen & 0,027 & 0,020 & 0,145 \\
\hline & Generiek vereist/surplus & $\underline{0,120}$ & $\underline{0,116}$ & $\underline{-0,116}$ \\
\hline & Adj. R-2 & $\overline{0,013}$ & $\overline{0,011}$ & 0,024 \\
\hline \multirow[t]{6}{*}{3} & Specifiek voorbereiding/eigen & $-0,005$ & 0,015 & 0,009 \\
\hline & Specifiek vereist/surplus & 0,145 & $\underline{0,133}$ & $-0,073$ \\
\hline & Generiek voorbereiding/eigen & 0,031 & $\overline{0,021}$ & $\underline{0,140}$ \\
\hline & Generiek vereist/surplus & 0,064 & 0,027 & $-\overline{0,087}$ \\
\hline & Adj. R-2 & 0,026 & 0,018 & 0,023 \\
\hline & $\mathrm{N}=$ & 439 & 453 & 383 \\
\hline & Domein Communications & & & \\
\hline \multirow[t]{3}{*}{1} & Specifiek voorbereiding/eigen & $-0,116$ & $-0,027$ & 0,085 \\
\hline & Specifiek vereist/surplus & 0,143 & 0,036 & $-0,104$ \\
\hline & Adj. R-2 & 0,012 & $-0,012$ & 0,002 \\
\hline \multirow[t]{3}{*}{2} & Generiek voorbereiding/eigen & $-0,126$ & $-0,161$ & 0,007 \\
\hline & Generiek vereist/surplus & 0,164 & $\underline{0,186}$ & $-0,073$ \\
\hline & Adj. R-2 & 0,017 & $\overline{0,030}$ & $-0,008$ \\
\hline \multirow[t]{6}{*}{3} & Specifiek voorbereiding/eigen & $-0,077$ & 0,110 & 0,116 \\
\hline & Specifiek vereist/surplus & 0,095 & $-0,146$ & $-0,100$ \\
\hline & Generiek voorbereiding/eigen & $-0,081$ & $-0,250$ & $-0,058$ \\
\hline & Generiek vereist/surplus & 0,127 & $\underline{0,270}$ & $-0,012$ \\
\hline & & 0,012 & 0,031 & $-0,009$ \\
\hline & $\mathrm{N}=$ & 145 & 152 & 155 \\
\hline
\end{tabular}

Vet: $\mathrm{P}<0,01 ;$ onderstreept: $\mathrm{P}<0,05$ 


\subsection{Item non-respons}

Bij de interpretatie van de resultaten dient rekening te worden gehouden met feit dat het nieuwe instrument slechts een van in principe oneindig veel mogelijke invullingen is van het begrip domeinspecifiek. Een potentieel probleem met de gebruikte lijst is dat de toelichtingen bij de items soms nogal lang en complex zijn (zie Appendix 1). Om na te gaan in hoeverre afgestudeerden zich hieraan hebben gestoord, is een analyse verricht van de item non-respons op deze vragen, afgezet tegen de items die in de vragenlijst direct aan het blok competentievragen voorafging en de vragen direct daarna. Figuur 2.9 geeft een samenvatting van deze analyse weer. Ter vergelijking is tevens de item non-respons op de reguliere vragenlijst, die identiek was behalve het competentieblok, weergegeven.

Het is duidelijk dat de competentievragen als belastend worden ervaren. De gemiddelde item non-respons neemt toe bij de competentievragen en zakt weer af direct daarna. Verder blijkt dat de item non-respons na het competentievragenblok bij zowel de reguliere- als de steekproefvragenlijst veel hoger blijft dan daarvoor. Met andere woorden: zowel bij de reguliere- als bij de steekproefvragenlijst stoppen veel mensen abrupt met invullen van de vragenlijst op dit punt.

\section{Figuur 2.9}

Gemiddeld percentage item missing per vragenblok, reguliere vragenlijst versus domein competentie lijst

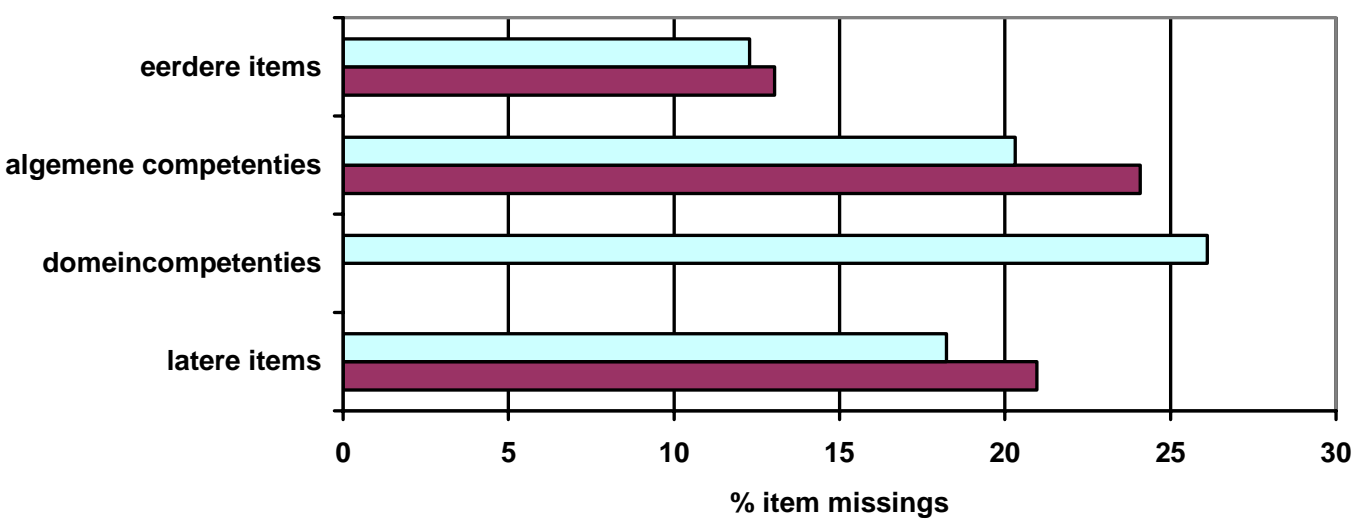

$\square$ reguliere vragenlijst $\square$ steekproef domeincompetenties 


\section{Samenvatting en conclusie}

In de uitgevoerde tests is gekeken naar achtereenvolgens:

1. gemiddelde scores en spreiding van antwoorden m.b.t. enerzijds vereist competentieniveau en anderzijds eigen competentieniveau c.q. voorbereiding door de opleiding;

2. algemene versus domeinspecifieke formulering van vakkennis;

3. voorspellende validiteit (1) gemiddelde correlaties met oordeel over startbekwaamheid, ontwikkelpotentieel en benutting van capaciteiten); (2) regressieanalyses van startbekwaamheid, ontwikkelpotentieel en uurloon;

4. item non-respons.

De belangrijkste bevindingen kunnen als volgt worden samengevat:

\section{1a Gemiddelde scores}

Vereist competentieniveau

Tegen de verwachting wordt binnen het kerndomein een relatief laag beroep gedaan op domeincompetenties. Blijkbaar 'werken' de huidige domeincompetenties niet goed. Er zijn forse verschillen tussen domeinen wat de vereiste competenties betreft.

\section{Eigen competentieniveau}

Men is iets positiever over de generieke dan over de vakspecifieke competenties. Er zijn geen grote verschillen tussen domeinen wat de voorbereiding door de opleiding betreft.

\section{1b Spreiding van antwoorden}

Vereist + eigen competentieniveau

Tegen de verwachting is de gemiddelde spreiding iets groter bij de domeincompetenties dan bij de algemene competenties in de pilot en de competenties in de reguliere vragenlijst.

\section{Algemene versus domeinspecifieke formulering van vakkennis}

Het is niet goed mogelijk om domeinspecifiek geformuleerde vakcompetenties door middel van algemeen geformuleerde items te meten. 


\section{3a Voorspellende validiteit: gemiddelde correlaties}

Eigen competentieniveau

De startbekwaamheid en het ontwikkelpotentieel correleren het sterkst met de algemene competenties in de pilot. Hier voldoet de pilot-lijst beter dan de reguliere lijst.

\section{Vereist competentieniveau}

De benutting van kennis en vaardigheden correleert even sterk met de competenties in de reguliere lijst als met de algemene- en domeincompetenties in de pilotlijst.

\section{3b Voorspellende validiteit: regressieanalyses}

Dat het uurloon beter wordt voorspeld door de reguliere lijst pleit niet voor de pilot-lijst. Overigens is men in de pilot-lijst met algemeen geformuleerde items niet slechter af dan met specifieke items.

\section{Item non-respons}

Bij zowel de reguliere lijst als de pilot-lijst worden de competentievragen als belastend ervaren.

In onderstaand schema staan de belangrijkste bevindingen samengevat.

\begin{tabular}{|c|c|c|c|}
\hline & $\begin{array}{l}\text { Reguliere compe- } \\
\text { tentielijst }\end{array}$ & \multicolumn{2}{|c|}{$\begin{array}{c}\text { Nieuwe } \\
\text { competentielijsten }\end{array}$} \\
\hline & & Algemeen & Domeinspecifiek \\
\hline Gem. scores op vereist niveau & hoog & hoog & matiga \\
\hline Verschil vereist niveau binnen vs buiten kerndomein & groot & groot & groota \\
\hline Gem. spreiding vereist niveau & groot & groot & grootb \\
\hline $\begin{array}{l}\text { Mogelijkheid om vakspecifieke competenties algemeen te } \\
\text { formuleren: correlatie met vereist niveau }\end{array}$ & n.v.t. & \multicolumn{2}{|c|}{ zwak } \\
\hline $\begin{array}{l}\text { Mogelijkheid om vakspecifieke competenties algemeen te } \\
\text { formuleren: correlatie met voorbereiding door opleiding }\end{array}$ & n.v.t. & \multicolumn{2}{|c|}{ zwak } \\
\hline $\begin{array}{l}\text { Voorspellende validiteit voor startbekwaamheid en ontwikkel- } \\
\text { potentieel }\end{array}$ & laag & redelijk-hoog & redelijk \\
\hline Voorspellende validiteit voor benutting van capaciteiten & redelijk & redelijk & laag-redelijk \\
\hline Voorspellende validiteit voor bruto uurloon & redelijk & laag-redelijk & laag-redelijk \\
\hline Item non-respons & hoog & minder hoog & hoog \\
\hline
\end{tabular}
Noten:

a. Zou te maken kunnen hebben met (1) selectie van de items en/of (2) formulering van de items.

b. Juist bij domeincompetenties zou minder spreiding zijn verwacht 


\section{Conclusie}

De tests laten zien dat generieke competenties voor accreditatiedoeleinden de voorkeur verdienen boven domeinspecifieke competenties. Op de meeste punten scoren generieke competenties minstens even goed als domeinspecifieke competenties en op sommige punten zelfs beter. Gelet op de grote investering om domeinspecifieke competenties jaarlijks in de meting op te nemen, verdienen generieke competenties - omdat zij op alle opleidingen toepasbaar zijn -de voorkeur. Dit laat onverlet dat opleidingen in het kader van kwaliteitszorg en curriculumevaluatie desgewenst additioneel domeinspecifieke competenties kunnen opnemen.

De tests laten verder zien dat de competentievragen in de reguliere hbo-lijst en de generieke competentievragen in de pilotlijst elkaar niet veel ontlopen wat de resultaten van de uitgevoerde tests betreft. Echter, vanwege hun duidelijk maatschappelijke draagvlak verdient het aanbeveling om de Dublin descriptoren als basis te gebruiken voor de formulering van de generieke competenties. Overigens staat de precieze formulering van de generieke competenties nog open. Of de huidige generieke items een optimale vertaling vormen van de Dublin descriptoren moet in goed overleg met stakeholders nog nader worden bekeken en vastgesteld. 


\section{Appendix 1: Steekproeflijst domeincompetenties HBO- Monitor 2007}

Binnen het $\mathrm{HBO}$ wordt steeds meer gedacht in termen van competenties. Daarom willen wij u vriendelijk verzoeken om tot slot van deze vragenlijst onderstaand vragenblok in te vullen. Bij voorbaat hartelijk dan hiervoor.

Hieronder staat een aantal competenties die in het werk van belang kunnen zijn. Geef voor iedere competentie aan: - (indien u werkt) het niveau dat vereist is in uw huidige functie

- hoe goed uw HBO-opleiidng u heeft voorbereid

Vereist niveau in huidige functie

matig <-> uitmuntend
Voorbereiding door HBOopleiding

volstrekt

onvol- vol- zeer doende doende goed

\section{Algemene competenties (opgesteld in Europees verband)}

- Kennis en inzicht van uw eigen vakgebied*

- Vermogen om de laatste ontwikkelingen in uw vakgebied eigen te maken*

- Vermogen om uw vakkennis en -inzicht op professionele wijze toe te passen*

- Vermogen om problemen op uw vakgebied op te lossen*

- Vermogen om relevante informatie te verzamelen en $\quad 1$ te interpreteren

- Vermogen om argumenten aan te voeren en te verdiepen

- Vermogen om een afgewogen oordeel te vormen

- Vermogen om aan anderen duidelijk te maken wat u bedoelt

- Vermogen om uw kennis op een substantieel hoger niveau te brengen

$\begin{array}{llllllll}1 & 3 & 5 & 1 & 2 & 3 & 4 & 5 \\ 1 & 3 & 5 & 1 & 2 & 3 & 4 & 5 \\ 1 & 3 & 5 & 1 & 2 & 3 & 4 & 5 \\ 1 & 3 & 5 & 1 & 2 & 3 & 4 & 5 \\ 1 & 3 & 5 & 1 & 2 & 3 & 4 & 5 \\ 1 & 3 & 5 & 1 & 2 & 3 & 4 & 5 \\ 1 & 3 & 5 & 1 & 2 & 3 & 4 & 5 \\ 1 & 3 & 5 & 1 & 2 & 3 & 4 & 5 \\ 1 & 3 & 5 & 1 & 2 & 3 & 4 & 5\end{array}$

Opleidingsspecifieke competenties (opgesteld door uw opleidingssector) Domein Bachelor of Economics

- Beheersing informatiesystemen.

Ontwerpen, inrichten en onderhouden van

(geautomatiseerde) informatiesystemen voor het besturen van organisaties.

- Beheersing administratieve organisatie

Vormgeven, inrichten en toetsen van de administratieve organisatie

- Beheersing financieel-economische en fiscale risico's Bepalen en beheersen van financieel-economische en fiscale risico's

- Verstrekken van financieel-economische en fiscale informatie

Bepalen en verstrekken van financieel-economische en fiscale informatie voor besluitvorming 
- Extern verstrekken van informatie

Verstrekken van informatie t.b.v. externe belang-

hebbenden

- Adviseren op financieel-economisch en fiscaal terrein

Geven van adviezen en verlenen van diensten op

financieel-economisch en fiscaal terrein aan belang-

hebben
Vereist niveau in hui-

\section{dige functie}

matig <-> uitmuntend
3

5

1
Voorbereiding door HBOopleiding

volstrekt

onvol- vol- zeer

doende doende goed

$\begin{array}{lllll}1 & 2 & 3 & 4 & 5\end{array}$

Opleidingsspecifieke competenties (opgesteld door uw opleidingssector) Domein Bachelor of Commerce

- Creëren producten en diensten

Initiëren en creëren van producten en diensten,

zelfstandig en ondernemend

- Beheersing marktonderzoek

Uitvoeren, interpreteren, toetsen en evalueren van marktonderzoek

- Analyse interne en externe omgeving

Vaststellen voor een onderneming van enerzijds de sterktes en zwaktes op basis van een analyse van de interne bedrijfsprocessen en -cultuur, als onderdeel van de waardeketen, en anderzijds van de kansen en bedreigingen op de lokale, nationale en/of internationale markt op basis van relevante nationale en internationale trends

- Ontwikkelen marketingbeleid

Ontwikkelen van marketingbeleid

(ondernemingsbeleid) voor een nationaal of internationaal opererende onderneming en het kunnen onderbouwen en beargumenteren van gemaakte keuzes

- Implementatie marketingbeleid

Opstellen, uitvoeren en bijstellen van plannen vanuit het marketingbeleid (ondernemingsbeleid)

- Zakelijke relaties onderhouden

Ontwikkelen en onderhouden van zakelijke relaties ten behoeve van inkoop, verkoop en dienstverlening

- $\quad$ Communiceren in interculturele context

Communiceren in meer talen en rekening houdend met culturele verschillen, intern en extern, nationaal en internationaal

- Leiding geven

Leiding geven aan een bedrijf, een bedrijfsonder-

deel, bedrijfsprocessen of een project

\begin{tabular}{|c|c|c|c|c|c|c|}
\hline 1 & 3 & 5 & 1 & 2 & 3 & 4 \\
\hline 1 & 3 & 5 & 1 & 2 & 3 & 4 \\
\hline 1 & 3 & 5 & 1 & 2 & 3 & 4 \\
\hline 1 & 3 & 5 & 1 & 2 & 3 & 4 \\
\hline 1 & 3 & 5 & 1 & 2 & 3 & 4 \\
\hline 1 & 3 & 5 & 1 & 2 & 3 & 4 \\
\hline 1 & 3 & 5 & 1 & 2 & 3 & 4 \\
\hline 1 & 3 & 5 & 1 & 2 & 3 & 4 \\
\hline
\end{tabular}

Opleidingsspecifieke competenties (opgesteld door uw opleidingssector) Domein Bachelor of Business Administration

Analyse externe omgeving

1

Ontwikkelen van een visie op veranderingen en

135

1

23 
trends in de externe omgeving en ontwikkelen van

Vereist niveau in hui-

\section{dige functie}

matig <-> uitmuntend
Voorbereiding door HBOopleiding

volstrekt

onvol- vol- zeer

doende doende goed

relaties, netwerken en ketens

- Beleidsontwikkeling

Analyseren van beleidsvraagstukken, vertalen in

beleidsdoelstellingen en -alternatieven en voorbereiden van besluitvorming

- Human resource management

Toepassen van human resource management in het licht van de strategie van de organisatie

- Procesmanagement

Inrichten, beheersen en verbeteren van bedrijfs- of organisatieprocessen

- $\quad$ Analyseren financiële en juridische aspecten en interne omgeving

Analyseren van de financiële en juridische aspecten, interne processen en de bedrijfs- of organisatieomgeving om samenhang en wisselwerking te versterken

- Verandermanagement

Ontwikkelen, implementeren en evalueren van een veranderingsproces

Opleidingsspecifieke competenties (opgesteld door uw opleidingssector) Domein Bachelor of Communications

- Onderzoeken communicatieprocessen

Doen van onderzoek naar onderwerpen en/of communicatieprocessen [Onderzoeken]

- Analyseren communicatieprocessen

Analyseren van informatiebehoeften en communicatieprocessen in hun onderlinge samenhang en in de context van de (internationale) omgeving [Analyseren]

- Formuleren en geven van advies

Formuleren van of adviseren over de vorm en functies van een product, rekening houdend met (internationale) regels en conventies; doen hiervan in het Nederlands en/of in een of meer vreemde talen [Formuleren en Adviseren]

- Ontwikkelen van producten en processen Ontwikkelen van een doelgroepgericht communicatie- en informatieproces of -product op basis van een strategisch beleidskader en/of andere gestelde kaders voor kwaliteit, doorlooptijd en budget, alsmede rekening houden met van toepassing zijnde (internationale regels en conventies. [Ontwikkelen]

- Realiseren van producten en processen

Presenteren of op andere wijze onderwerpen aan een kritische toets door anderen van een communi- 
catie/informatie product en/of communica-

Vereist niveau in hui-

\section{dige functie}

matig <-> uitmuntend
Voorbereiding door HBOopleiding

volstrekt

onvol- vol- zeer

doende doende goed

tie/informatie processen [Realiseren]

- Evalueren van producten/processen

Evalueren van communicatie/informatie producten en/of communicatie/informatie processen en voorstellen doen voor verbetering (Evalueren]

- $\quad$ Communiceren in interculturele context

Communiceren in het Nederlands en/of in een of meer vreemde talen en toepassen van deze talen in een interculturele context in het kader van de andere domeincompetenties

Opleidingsspecifieke competenties (opgesteld door uw opleidingssector) Domein Bachelor of Law

- Adviseren bij juridische vraagstukken

Adviseren van klanten en opdrachtgevers bij juridische vragen en problemen

- Behartigen van de juridische belangen

Behartigen van de juridische belangen van klanten en opdrachtgevers, en verleent rechtsbijstand

- Onderhandelen en bemiddelen

Onderhandelen en bemiddelen in een geschil of conflict om tot een oplossing te komen

Coördineren van werkprocessen binnen de organisatie en bewaken daarbij van juridische en bestuurlijke procedures en termijnen

- $\quad$ Analyseren en selecteren van informatie Selecteren en analyseren van externe informatie op juridische en maatschappelijke relevantie

- Juridische effecten signaleren en verwerken in beleidsvoorstellen

Signaleren van effecten van (nieuwe) wet- en regelgeving voor klanten en voor de eigen organisatie, en voorstellen van verbeteringen in de werkprocessen of het beleid van de organisatie
- Coördineren van werkprocessen

\begin{tabular}{|c|c|c|c|c|c|c|}
\hline 1 & 3 & 5 & 1 & 2 & 3 & 4 \\
\hline 1 & 3 & 5 & 1 & 2 & 3 & 4 \\
\hline 1 & 3 & 5 & 1 & 2 & 3 & 4 \\
\hline 1 & 3 & 5 & 1 & 2 & 3 & 4 \\
\hline 1 & 3 & 5 & 1 & 2 & 3 & 4 \\
\hline 1 & 3 & 5 & 1 & 2 & 3 & 4 \\
\hline
\end{tabular}

\section{Opleidingsspecifieke competenties (opgesteld door uw opleidingssector)} Domein Bachelor of ICT stromen

Voert een analyse uit van processen, producten en informatiestromen in hun onderlinge samenhang en de context van de omgeving. Stelt functionele specificaties op

- $\quad$ Adviseren m.b.t. processen, informatiestromen of ict-systemen

Formuleert op basis van een analyse en in overleg 
Vereist niveau in hui-

\section{dige functie}

matig <-> uitmuntend
Voorbereiding door HBOopleiding

volstrekt

onvol- vol- zeer

doende doende goed

met stakeholders een onderbouwd advies voor de herinrichting van processen en/of informatiestromen en voor een nieuw te ontwikkelen of aan te schaffen ict-systeem. Betrekt hierin financiële aspecten, tijdaspecten, de organisatie(verandering), haalbaarheid en risico's en mogelijkheden voor outsourcing

- Ontwerpen van ict-systemen

Ontwerpt een ict-systeem op basis van een architectuurbeschrijving en specificaties, in samenhang met een analyse en binnen de gestelde kaders voor kwaliteit, testen, beveiliging, doorlooptijd, budget en exploitatie en beheer

- Realiseren van ict-systemen

Bouwt en implementeert een ict-systeem op basis van een functioneel en technisch ontwerp en binnen de gestelde kaders voor kwaliteit, testen, beveiliging, doorlooptijd, budget en exploitatie en beheer

- Beheren van ict-systemen

Geeft vorm aan de exploitatie en het beheer van ictsystemen. Zorgt voor invoeren, testen, integreren en inbedrijfstelling van een nieuw(e release van een) ict-systeem. Verleent diensten die zijn overeengekomen (in een Service Level Agreement) binnen de gestelde kaders voor kwaliteit en financiën. Zorgt in samenhang met ontwerp en bouw voor het onderhoud van ict-systemen

* Onder vakgebied wordt verstaan: het vakgebied waarin u bent opgeleid. 


\title{
5 Appendix 2: Standaard competentie-instrument HBO- Monitor 2007
}

Hieronder staat een aantal aspecten die in werk van belang kunnen zijn. Geef voor ieder aspect een inschatting van:

- (indien u werkt) het niveau dat vereist is in uw huidige functie - uw eigen niveau;

Kennis van:

a. uw eigen vakgebied

b. andere vakgebieden Vermogen om:

c. uw vakkennis in de praktijk toe te passen

d. informatie- \& communicatietechnologie te gebruiken

e. in buitenlandse talen te communiceren

f. informatie te vergaren

g. problemen en kansen te signaleren

h. verbanden te leggen tussen verschillende zaken

i. hoofd- van bijzaken te onderscheiden

j. logisch te redeneren

k. conform budget, planning of richtlijnen te werken

I. onder druk goed te functioneren

m. knopen door te hakken

n. nieuwe ideeën en oplossingen te bedenken

o. nieuwe dingen te leren

p. aan anderen duidelijk te maken wat u bedoelt

q. productief met anderen samen te werken

r. capaciteiten van anderen aan te spreken

s. zelfstandig de werkzaamheden uit te voeren Bereidheid om:

t. uw nek uit te steken

u. ideeën van uzelf en anderen ter discussie te stellen

v. op te komen voor uw eigen standpunt

w. begrip te tonen voor andere standpunten

\author{
Het vereist niveau in uw Uw eigen niveau \\ huidige functie \\ matig <-> uitmuntend matig <-> uitmuntend
}

$\begin{array}{llllllllll}1 & 2 & 3 & 4 & 5 & 1 & 2 & 3 & 4 & 5\end{array}$

$\begin{array}{llllllllll}1 & 2 & 3 & 4 & 5 & 1 & 2 & 3 & 4 & 5\end{array}$

$\begin{array}{llllllllll}1 & 2 & 3 & 4 & 5 & 1 & 2 & 3 & 4 & 5\end{array}$

$\begin{array}{llllllllll}1 & 2 & 3 & 4 & 5 & 1 & 2 & 3 & 4 & 5\end{array}$

$\begin{array}{llllllllll}1 & 2 & 3 & 4 & 5 & 1 & 2 & 3 & 4 & 5\end{array}$

$\begin{array}{llllllllll}1 & 2 & 3 & 4 & 5 & 1 & 2 & 3 & 4 & 5\end{array}$

$\begin{array}{llllllllll}1 & 2 & 3 & 4 & 5 & 1 & 2 & 3 & 4 & 5\end{array}$

$\begin{array}{llllllllll}1 & 2 & 3 & 4 & 5 & 1 & 2 & 3 & 4 & 5\end{array}$

$\begin{array}{llllllllll}1 & 2 & 3 & 4 & 5 & 1 & 2 & 3 & 4 & 5\end{array}$

$\begin{array}{llllllllll}1 & 2 & 3 & 4 & 5 & 1 & 2 & 3 & 4 & 5\end{array}$

$\begin{array}{llllllllll}1 & 2 & 3 & 4 & 5 & 1 & 2 & 3 & 4 & 5\end{array}$

$\begin{array}{llllllllll}1 & 2 & 3 & 4 & 5 & 1 & 2 & 3 & 4 & 5\end{array}$

$\begin{array}{llllllllll}1 & 2 & 3 & 4 & 5 & 1 & 2 & 3 & 4 & 5\end{array}$

$\begin{array}{llllllllll}1 & 2 & 3 & 4 & 5 & 1 & 2 & 3 & 4 & 5\end{array}$

$\begin{array}{llllllllll}1 & 2 & 3 & 4 & 5 & 1 & 2 & 3 & 4 & 5\end{array}$

$\begin{array}{llllllllll}1 & 2 & 3 & 4 & 5 & 1 & 2 & 3 & 4 & 5\end{array}$

$\begin{array}{llllllllll}1 & 2 & 3 & 4 & 5 & 1 & 2 & 3 & 4 & 5\end{array}$

$\begin{array}{llllllllll}1 & 2 & 3 & 4 & 5 & 1 & 2 & 3 & 4 & 5\end{array}$

$\begin{array}{llllllllll}1 & 2 & 3 & 4 & 5 & 1 & 2 & 3 & 4 & 5\end{array}$

$\begin{array}{llllllllll}1 & 2 & 3 & 4 & 5 & 1 & 2 & 3 & 4 & 5\end{array}$

$\begin{array}{llllllllll}1 & 2 & 3 & 4 & 5 & 1 & 2 & 3 & 4 & 5\end{array}$

$\begin{array}{llllllllll}1 & 2 & 3 & 4 & 5 & 1 & 2 & 3 & 4 & 5\end{array}$

$\begin{array}{llllllllll}1 & 2 & 3 & 4 & 5 & 1 & 2 & 3 & 4 & 5\end{array}$ 


\section{Appendix 3: Beschrijvende tabellen van algemene compe- tenties in de pilot}

\subsection{Vereist niveau in huidige functie van algemene competenties}

Het vereiste niveau in de huidige functie heeft in deze appendix betrekking op afgestudeerden die werkzaam zijn in functies op hbo-niveau. Het vereiste niveau is gemeten op een 5-puntschaal (1 'matig' <-> 5 'uitmuntend'). De tabellen vermelden het \% laag (antwoordcategorie 1, 2 en 3) en het \% hoog (antwoordcategorie 4 en 5). De cijfers in grijs in deze appendix hebben betrekking op minder dan 20 respondenten.

Vereist niveau: Kennis en inzicht van uw eigen vakgebied

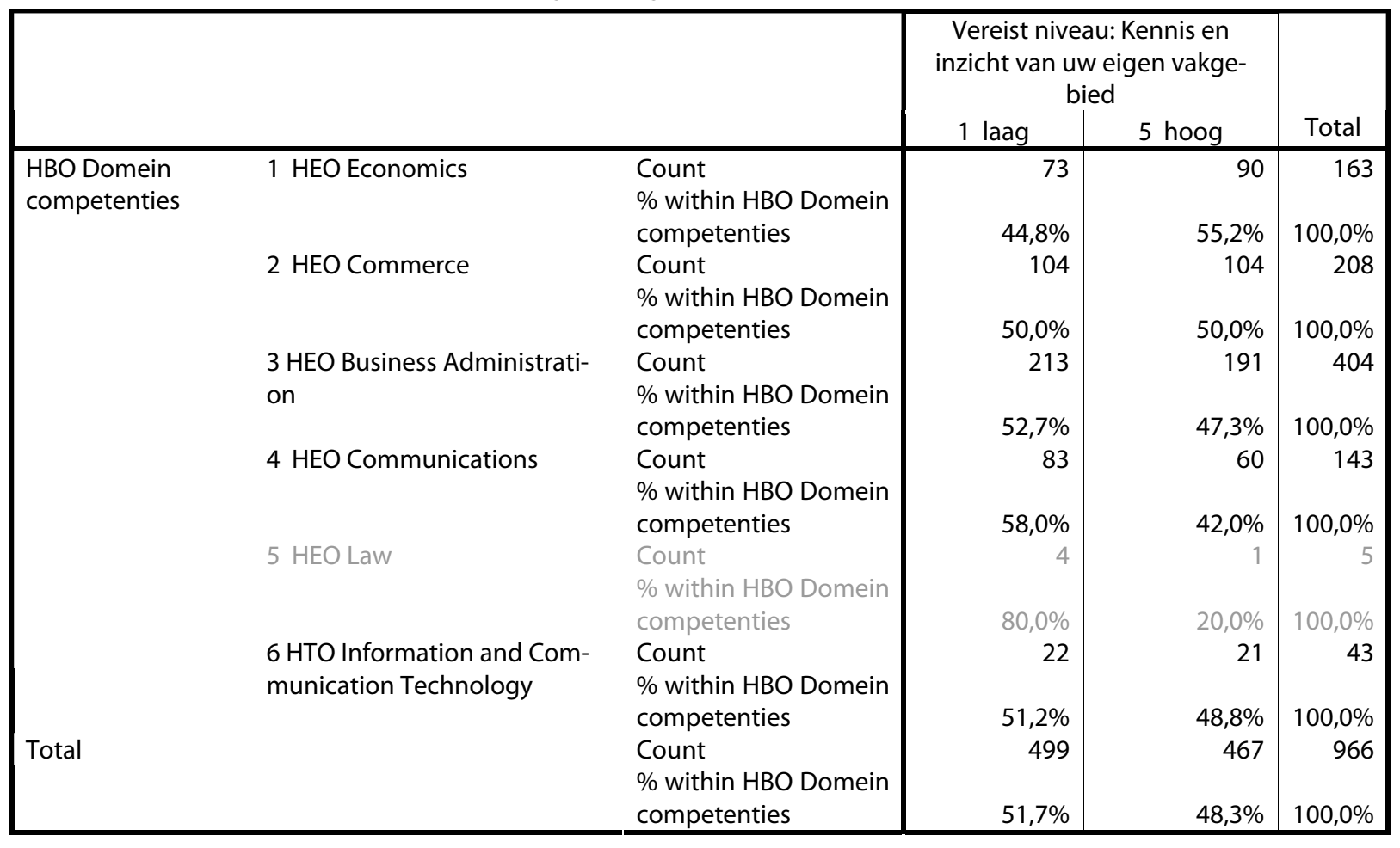


Vereist niveau: Vermogen om de laatste ontwikkelingen in uw vakgebied eigen te maken

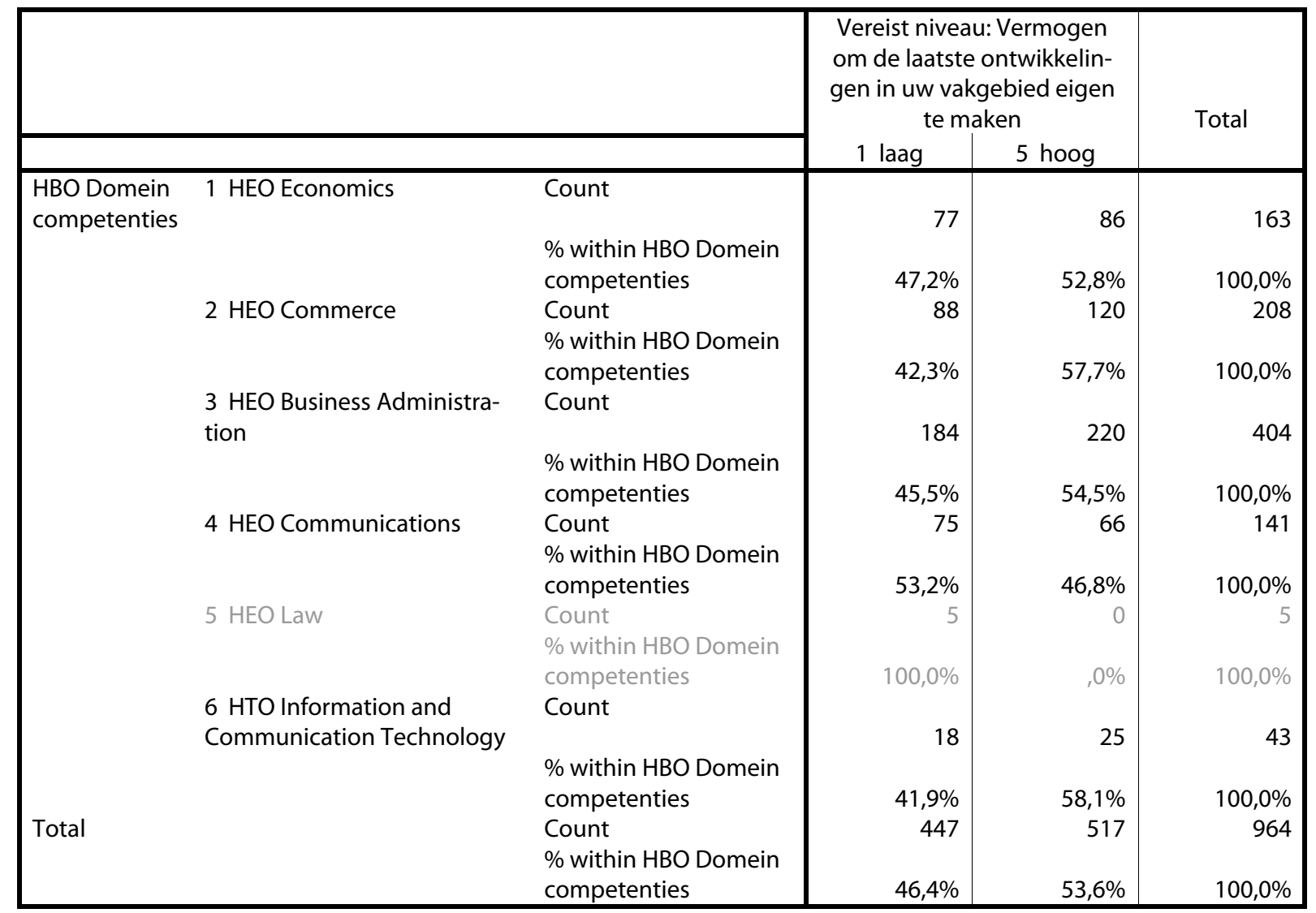

Vereist niveau: Vermogen om uw vakkennis en -inzicht op professionele wijze toe te passen

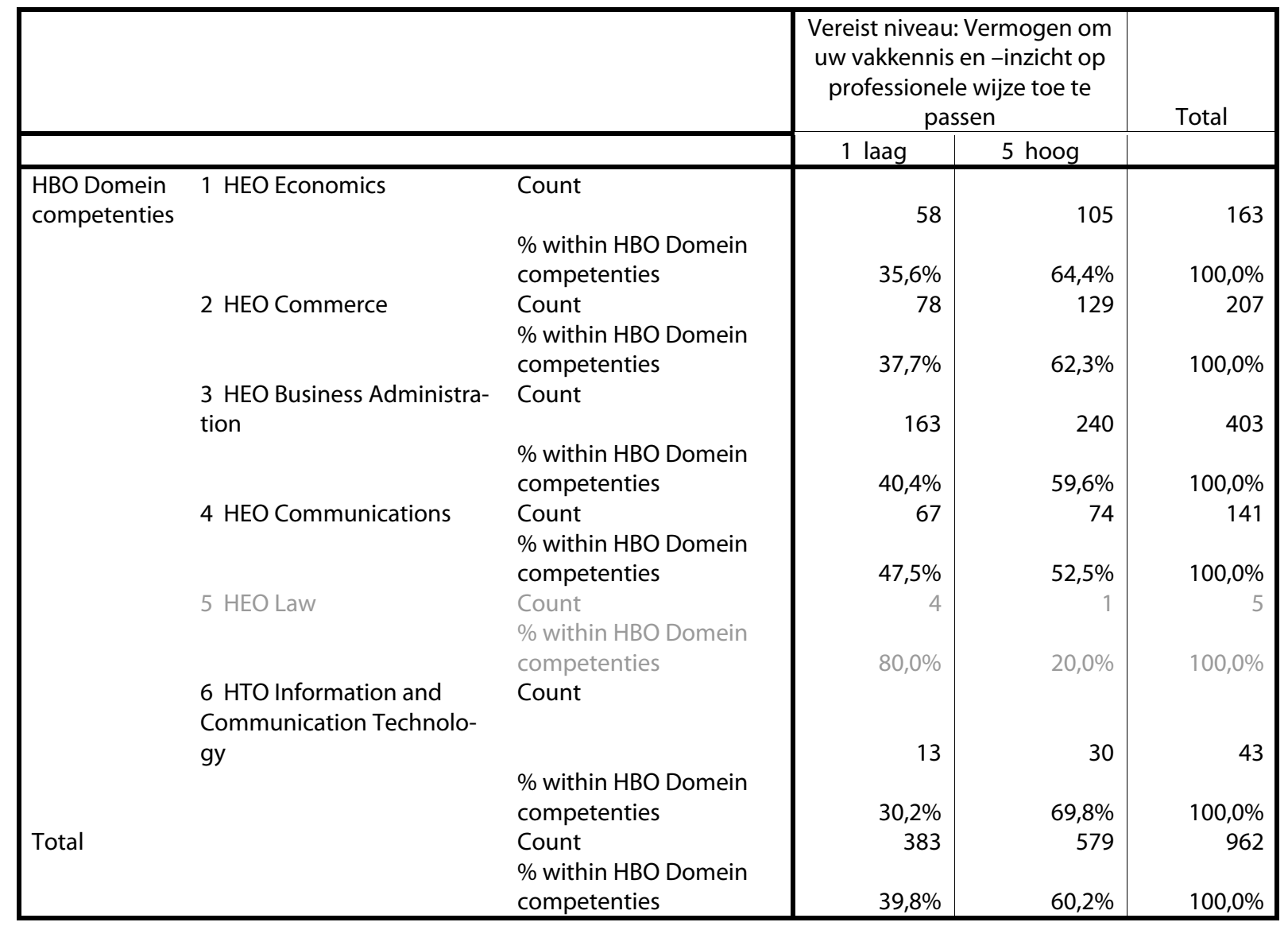


Vereist niveau: Vermogen om problemen op uw vakgebied op te lossen

\begin{tabular}{|c|c|c|c|c|c|}
\hline & & & \multicolumn{2}{|c|}{$\begin{array}{l}\text { Vereist niveau: Vermogen } \\
\text { om problemen op uw vak- } \\
\text { gebied op te lossen }\end{array}$} & \multirow[t]{2}{*}{ Total } \\
\hline & & & 1 laag & 5 hoog & \\
\hline $\begin{array}{l}\text { HBO Domein } \\
\text { competenties }\end{array}$ & $\begin{array}{l}1 \text { HEO Economics } \\
2 \text { HEO Commerce } \\
3 \text { HEO Business Admini- } \\
\text { stration } \\
4 \text { HEO Communications } \\
5 \text { HEO Law } \\
6 \text { HTO Information and } \\
\text { Communication Techno- } \\
\text { logy }\end{array}$ & $\begin{array}{l}\text { Count } \\
\text { \% within HBO Domein } \\
\text { competenties } \\
\text { Count } \\
\% \text { within HBO Domein } \\
\text { competenties } \\
\text { Count } \\
\text { \% within HBO Domein } \\
\text { competenties } \\
\text { Count } \\
\text { \% within HBO Domein } \\
\text { competenties } \\
\text { Count } \\
\text { \% within HBO Domein } \\
\text { competenties } \\
\text { Count } \\
\text { \% within HBO Domein } \\
\text { competenties } \\
\text { Count } \\
\text { \% within HBO Domein } \\
\text { competenties }\end{array}$ & $\begin{array}{r}64 \\
39,3 \% \\
77 \\
37,2 \% \\
156 \\
38,8 \% \\
67 \\
47,5 \% \\
2 \\
40,0 \% \\
\\
17 \\
40,5 \% \\
383 \\
39,9 \% \\
\end{array}$ & $\begin{array}{r}99 \\
60,7 \% \\
130 \\
62,8 \% \\
246 \\
\\
61,2 \% \\
74 \\
52,5 \% \\
3 \\
\\
60,0 \% \\
\\
25 \\
59,5 \% \\
577 \\
60,1 \% \\
\end{array}$ & $\begin{array}{r}163 \\
100,0 \% \\
207 \\
100,0 \% \\
402 \\
100,0 \% \\
141 \\
100,0 \% \\
5 \\
100,0 \% \\
\\
42 \\
100,0 \% \\
960 \\
100,0 \% \\
\end{array}$ \\
\hline
\end{tabular}

Vereist niveau: Vermogen om relevante informatie te verzamelen en te interpreteren

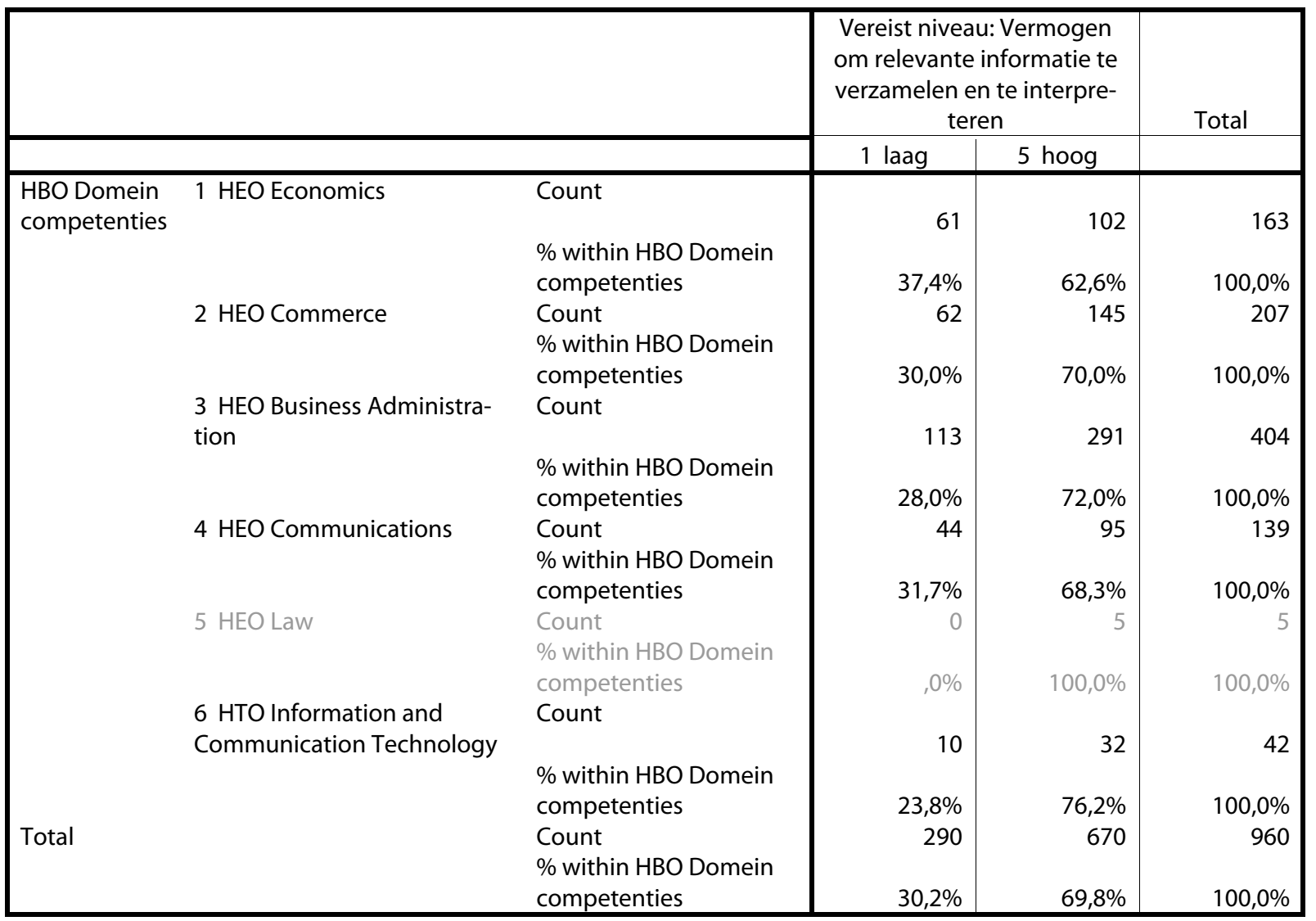


Vereist niveau: Vermogen om argumenten aan te voeren en te verdiepen

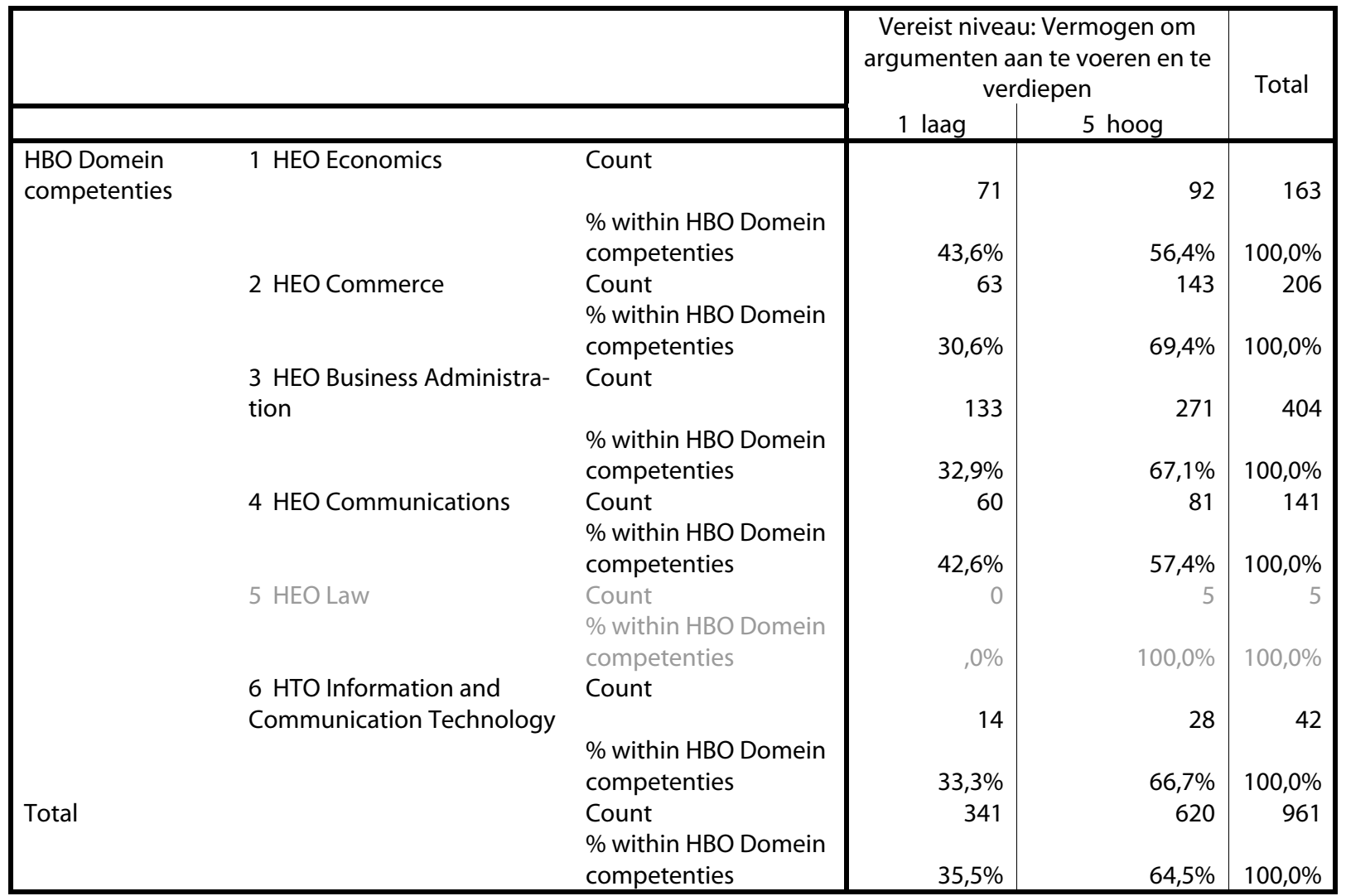

* Verschillen tussen domeinen significant op 5\%-niveau.

Vereist niveau: Vermogen om een afgewogen oordeel te vormen

\begin{tabular}{|c|c|c|c|c|c|}
\hline & & & \multicolumn{2}{|c|}{$\begin{array}{l}\text { Vereist niveau: Vermogen om } \\
\text { een afgewogen oordeel te } \\
\text { vormen }\end{array}$} & \multirow[t]{2}{*}{ Total } \\
\hline & & & 1 laag & 5 hoog & \\
\hline $\begin{array}{l}\text { HBO Domein } \\
\text { competenties }\end{array}$ & $\begin{array}{l}1 \text { HEO Economics } \\
2 \text { HEO Commerce } \\
3 \text { HEO Business Administra- } \\
\text { tion } \\
4 \text { HEO Communications } \\
5 \text { HEO Law }\end{array}$ & $\begin{array}{l}\text { Count } \\
\text { \% within HBO Domein } \\
\text { competenties } \\
\text { Count } \\
\% \text { within HBO Domein } \\
\text { competenties } \\
\text { Count } \\
\% \text { within HBO Domein } \\
\text { competenties } \\
\text { Count } \\
\% \text { within HBO Domein } \\
\text { competenties } \\
\text { Count } \\
\text { \% within HBO Domein } \\
\text { competenties } \\
\text { Count } \\
\text { \% within HBO Domein } \\
\text { competenties } \\
\text { Count } \\
\% \text { within HBO Domein } \\
\text { competenties }\end{array}$ & $\begin{array}{r}72 \\
44,2 \% \\
72 \\
35,0 \% \\
134 \\
\\
33,3 \% \\
67 \\
47,5 \% \\
1 \\
20,0 \% \\
16 \\
\\
38,1 \% \\
362 \\
37,7 \%\end{array}$ & $\begin{array}{r}91 \\
55,8 \% \\
134 \\
65,0 \% \\
269 \\
\\
66,7 \% \\
74 \\
52,5 \% \\
4 \\
\\
80,0 \% \\
\\
26 \\
61,9 \% \\
598 \\
62,3 \%\end{array}$ & $\begin{array}{r}163 \\
100,0 \% \\
206 \\
100,0 \% \\
403 \\
100,0 \% \\
141 \\
100,0 \% \\
5 \\
100,0 \% \\
42\end{array}$ \\
\hline
\end{tabular}

\footnotetext{
* Verschillen tussen domeinen significant op 5\%-niveau.
} 
Vereist niveau: Vermogen om aan anderen duidelijk te maken wat u bedoelt

\begin{tabular}{|c|c|c|c|c|c|}
\hline & & & $\begin{array}{c}\text { Vereist niveau } \\
\text { aan anderen o } \\
\text { ken wat }\end{array}$ & $\begin{array}{l}\text { mogen om } \\
\text { elijk te ma- } \\
\text { doelt }\end{array}$ & Total \\
\hline & & & 1 laag & 5 hoog & \\
\hline $\begin{array}{l}\text { HBO Domein } \\
\text { competenties }\end{array}$ & $\begin{array}{l}1 \text { HEO Economics } \\
2 \text { HEO Commerce } \\
3 \text { HEO Business Administra- } \\
\text { tion } \\
4 \text { HEO Communications } \\
5 \text { HEO Law } \\
6 \text { HTO Information and } \\
\text { Communication Technology }\end{array}$ & $\begin{array}{l}\text { Count } \\
\text { \% within HBO Domein } \\
\text { competenties } \\
\text { Count } \\
\% \text { within HBO Domein } \\
\text { competenties } \\
\text { Count } \\
\% \text { within HBO Domein } \\
\text { competenties } \\
\text { Count } \\
\% \text { within HBO Domein } \\
\text { competenties } \\
\text { Count } \\
\text { \% within HBO Domein } \\
\text { competenties } \\
\text { Count } \\
\text { \% within HBO Domein } \\
\text { competenties } \\
\text { Count } \\
\% \text { within HBO Domein } \\
\text { competenties }\end{array}$ & $\begin{array}{r}61 \\
37,7 \% \\
51 \\
24,6 \% \\
116 \\
\\
28,9 \% \\
43 \\
30,5 \% \\
2 \\
40,0 \% \\
10 \\
23,8 \% \\
283 \\
29,5 \%\end{array}$ & $\begin{array}{r}101 \\
62,3 \% \\
156 \\
75,4 \% \\
285 \\
\\
71,1 \% \\
98 \\
69,5 \% \\
3 \\
\\
60,0 \% \\
\\
32 \\
76,2 \% \\
675 \\
70,5 \%\end{array}$ & $\begin{array}{r}162 \\
100,0 \% \\
207 \\
100,0 \% \\
401 \\
100,0 \% \\
141 \\
100,0 \% \\
5 \\
100,0 \% \\
42 \\
100,0 \% \\
958 \\
100,0 \%\end{array}$ \\
\hline
\end{tabular}

Vereist niveau: Vermogen om uw kennis op een substantieel hoger niveau te brengen

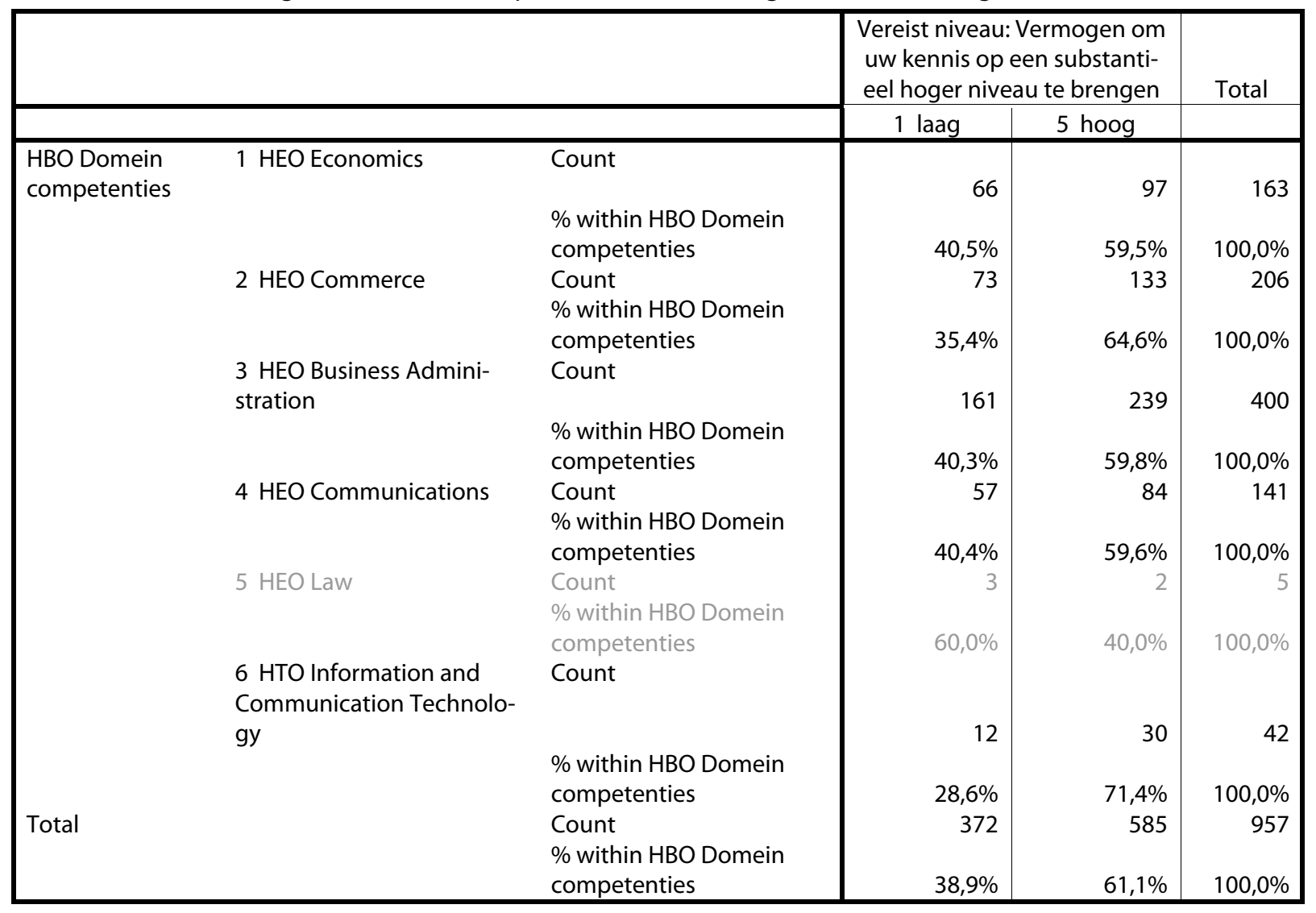




\subsection{Voorbereiding door hbo van algemene competenties}

De kwaliteit van de voorbereiding door het HBO heeft betrekking op alle afgestudeerden in de steekproef. De kwaliteit van de voorbereiding is gemeten op een 5puntschaal (1 'volstrekt onvoldoende'; 2 'onvoldoende'; 3 'voldoende' 4 'goed'; 5 'zeer goed'). De tabellen vermelden het \% (volstrekt) onvoldoende (antwoordcategorie 1 en 2), het \% voldoende (antwoordcategorie 3) en het \% (zeer) goed (antwoordcategorie 4 en 5 ).

Voorbereiding door HBO: Kennis en inzicht van uw eigen vakgebied

\begin{tabular}{|c|c|c|c|c|c|c|}
\hline & & & \multicolumn{3}{|c|}{$\begin{array}{l}\text { Voorbereiding door HBO: Kennis en inzicht } \\
\text { van uw eigen vakgebied }\end{array}$} & \multirow[t]{2}{*}{ Total } \\
\hline & & & $\begin{array}{l}1 \text { (volstrekt) } \\
\text { onvoldoende }\end{array}$ & $\begin{array}{c}3 \\
\text { voldoende }\end{array}$ & $\begin{array}{c}5 \\
\text { (zeer)goed }\end{array}$ & \\
\hline $\begin{array}{l}\text { HBO Domein } \\
\text { competenties }\end{array}$ & $\begin{array}{l}1 \text { HEO Economics } \\
2 \text { HEO Commerce } \\
3 \text { HEO Business } \\
\text { Administration } \\
4 \text { HEO Communi- } \\
\text { cations } \\
5 \text { HEO Law } \\
6 \text { HTO Informa- } \\
\text { tion and Commu- } \\
\text { nication Technol- } \\
\text { ogy }\end{array}$ & $\begin{array}{l}\text { Count } \\
\text { \% within HBO Domein } \\
\text { competenties } \\
\text { Count } \\
\text { \% within HBO Domein } \\
\text { competenties } \\
\text { Count } \\
\text { \% within HBO Domein } \\
\text { competenties } \\
\text { Count } \\
\text { \% within HBO Domein } \\
\text { competenties } \\
\text { Count } \\
\text { \% within HBO Domein } \\
\text { competenties } \\
\text { Count }\end{array}$ & $\begin{array}{r}22 \\
10,3 \% \\
39 \\
12,5 \% \\
85 \\
13,9 \% \\
40 \\
18,1 \% \\
0 \\
\\
40 \% \\
\\
7 \\
13,2 \% \\
193 \\
13,6 \%\end{array}$ & $\begin{array}{r}66,8 \% \\
192 \\
61,5 \% \\
381 \\
62,3 \% \\
135 \\
61,1 \% \\
6 \\
75,0 \% \\
\end{array}$ & $\begin{array}{r}22,9 \% \\
81 \\
26,0 \% \\
146 \\
\\
23,9 \% \\
46 \\
20,8 \% \\
2 \\
25,0 \%\end{array}$ & $\begin{array}{r}214 \\
100,0 \% \\
312 \\
100,0 \% \\
612 \\
100,0 \% \\
221 \\
100,0 \% \\
8 \\
100,0 \%\end{array}$ \\
\hline
\end{tabular}


Voorbereiding door HBO: Vermogen om de laatste ontwikkelingen in uw vakgebied eigen te maken

\begin{tabular}{|c|c|c|c|c|c|c|}
\hline & & & $\begin{array}{l}\text { Voorbereidin } \\
\text { de laatste ont }\end{array}$ & $\begin{array}{l}\text { door HBO: Ve } \\
\text { ikkelingen in } \\
\text { gen te maken }\end{array}$ & $\begin{array}{l}\text { rmogen om } \\
\text { w vakgebied }\end{array}$ & Total \\
\hline & & & $\begin{array}{c}1 \text { (volstrekt) } \\
\text { onvoldoende }\end{array}$ & $\begin{array}{c}3 \text { voldoen- } \\
\text { de }\end{array}$ & $\begin{array}{c}5 \\
\text { (zeer)goed }\end{array}$ & \\
\hline $\begin{array}{l}\text { HBO Domein } \\
\text { competenties }\end{array}$ & $\begin{array}{l}4 \text { HEO Communi- } \\
\text { cations } \\
5 \text { HEO Law } \\
6 \text { HTO Information } \\
\text { and Communica- } \\
\text { tion Technology }\end{array}$ & $\begin{array}{l}\text { Count } \\
\text { \% within HBO Domein } \\
\text { competenties } \\
\text { Count } \\
\% \text { within HBO Domein } \\
\text { competenties } \\
\text { Count } \\
\text { \% within HBO Domein } \\
\text { competenties } \\
\text { Count } \\
\text { \% within HBO Domein } \\
\text { competenties } \\
\text { Count } \\
\text { \% within HBO Domein } \\
\text { competenties } \\
\text { Count } \\
\text { \% within HBO Domein } \\
\text { competenties } \\
\text { Count } \\
\text { \% within HBO Domein } \\
\text { competenties }\end{array}$ & $\begin{array}{r}15,6 \% \\
54 \\
24,5 \% \\
0 \\
, 0 \% \\
\\
10 \\
\\
18,9 \% \\
235 \\
16,6 \%\end{array}$ & $\begin{array}{r}126 \\
58,9 \% \\
171 \\
55,3 \% \\
318 \\
52,2 \% \\
113 \\
51,4 \% \\
6 \\
75,0 \% \\
\\
\\
\\
\\
\\
\\
\\
45,3 \% \\
758 \\
53,6 \%\end{array}$ & $\begin{array}{r}53 \\
24,8 \% \\
97 \\
31,4 \% \\
196 \\
32,2 \% \\
53 \\
24,1 \% \\
2 \\
25,0 \% \\
\end{array}$ & $\begin{array}{r}214 \\
100,0 \% \\
309 \\
100,0 \% \\
609 \\
100,0 \% \\
220 \\
100,0 \% \\
8 \\
100,0 \% \\
\\
53 \\
\end{array}$ \\
\hline
\end{tabular}

* Verschillen tussen domeinen significant op 5\%-niveau. 
Voorbereiding door HBO: Vermogen om uw vakkennis en -inzicht op professionele wijze toe te passen

\begin{tabular}{|c|c|c|c|c|c|c|}
\hline & & & $\begin{array}{r}\text { Voorbereidin } \\
\text { uw vakkennis } \\
\text { wi }\end{array}$ & $\begin{array}{l}\text { door HBO: Ve } \\
\text { n -inzicht op } \\
\text { ze toe te passe }\end{array}$ & $\begin{array}{l}\text { mogen om } \\
\text { rofessionele }\end{array}$ & Total \\
\hline & & & $\begin{array}{l}1 \text { (volstrekt) } \\
\text { onvoldoende }\end{array}$ & $\begin{array}{l}3 \text { voldoen- } \\
\text { de }\end{array}$ & $\begin{array}{c}5 \\
\text { (zeer)goed }\end{array}$ & \\
\hline HBO Domein & 1 HEO Econo- & Count & 32 & 114 & 65 & 211 \\
\hline & & $\%$ within HBO Domein & $15,2 \%$ & $54,0 \%$ & $30,8 \%$ & $100,0 \%$ \\
\hline & 2 HEO Commer- & Count & 38 & 156 & 115 & 309 \\
\hline & & $\begin{array}{l}\% \text { within HBO Domein } \\
\text { competenties }\end{array}$ & $12,3 \%$ & $50,5 \%$ & $37,2 \%$ & $100,0 \%$ \\
\hline & $\begin{array}{l}3 \text { HEO Business } \\
\text { Administration }\end{array}$ & Count & 91 & 315 & 204 & 610 \\
\hline & & $\begin{array}{l}\% \text { within HBO Domein } \\
\text { competenties }\end{array}$ & $14,9 \%$ & $51,6 \%$ & $33,4 \%$ & $100,0 \%$ \\
\hline & $\begin{array}{l}4 \text { HEO Commu- } \\
\text { nications }\end{array}$ & Count & 38 & 122 & 61 & 221 \\
\hline & & $\begin{array}{l}\% \text { within HBO Domein } \\
\text { competenties }\end{array}$ & $17,2 \%$ & $55,2 \%$ & $27,6 \%$ & $100,0 \%$ \\
\hline & 5 HEO Law & Count & 0 & 3 & 5 & 8 \\
\hline & & $\begin{array}{l}\% \text { within HBO Domein } \\
\text { competenties }\end{array}$ &, $0 \%$ & $37,5 \%$ & $62,5 \%$ & $100,0 \%$ \\
\hline & 6 HTO Informa- & Count & & & & \\
\hline & $\begin{array}{l}\text { tion and Com- } \\
\text { munication }\end{array}$ & & 7 & 25 & 21 & 53 \\
\hline & & $\begin{array}{l}\% \text { within HBO Domein } \\
\text { competenties }\end{array}$ & $13,2 \%$ & $47,2 \%$ & $39,6 \%$ & $100,0 \%$ \\
\hline Total & & Count & 206 & 735 & 471 & 1412 \\
\hline & & $\begin{array}{l}\% \text { within HBO Domein } \\
\text { competenties }\end{array}$ & $14,6 \%$ & $52,1 \%$ & $33,4 \%$ & $100,0 \%$ \\
\hline
\end{tabular}


Voorbereiding door HBO: Vermogen om problemen op uw vakgebied op te lossen

\begin{tabular}{|c|c|c|c|c|c|c|}
\hline & & & \multicolumn{3}{|c|}{$\begin{array}{l}\text { Voorbereiding door HBO: Vermogen om } \\
\text { problemen op uw vakgebied op te lossen }\end{array}$} & \multirow[t]{2}{*}{ Total } \\
\hline & & & $\begin{array}{l}1 \text { (volstrekt) } \\
\text { onvoldoende }\end{array}$ & $\begin{array}{l}3 \text { voldoen- } \\
\text { de }\end{array}$ & $\begin{array}{c}5 \\
\text { (zeer)goed }\end{array}$ & \\
\hline $\begin{array}{l}\text { HBO Domein } \\
\text { competenties }\end{array}$ & $\begin{array}{l}1 \text { HEO Econo- } \\
\text { mics } \\
2 \text { HEO Commer- } \\
\text { ce } \\
3 \text { HEO Business } \\
\text { Administration } \\
4 \text { HEO Commu- } \\
\text { nications } \\
5 \text { HEO Law } \\
6 \text { HTO Informa- } \\
\text { tion and Com- } \\
\text { munication } \\
\text { Technology }\end{array}$ & $\begin{array}{l}\text { Count } \\
\text { \% within HBO Domein } \\
\text { competenties } \\
\text { Count } \\
\text { \% within HBO Domein } \\
\text { competenties } \\
\text { Count } \\
\text { \% within HBO Domein } \\
\text { competenties } \\
\text { Count } \\
\text { \% within HBO Domein } \\
\text { competenties } \\
\text { Count } \\
\% \text { within HBO Domein } \\
\text { competenties } \\
\text { Count } \\
\text { \% within HBO Domein } \\
\text { competenties } \\
\text { Count } \\
\text { \% within HBO Domein } \\
\text { competenties }\end{array}$ & 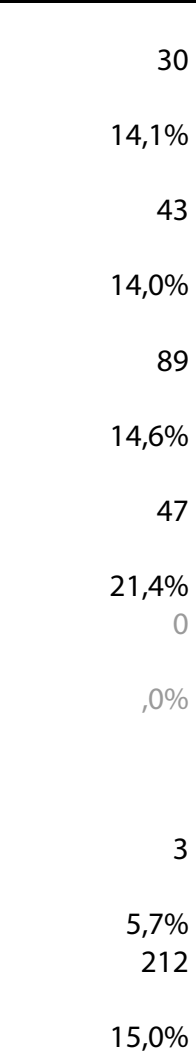 & $\begin{array}{r}119 \\
55,9 \% \\
156 \\
50,6 \% \\
301 \\
49,3 \% \\
115 \\
52,3 \% \\
3 \\
37,5 \% \\
\end{array}$ & $\begin{array}{r}64 \\
30,0 \% \\
109 \\
35,4 \% \\
220 \\
36,1 \% \\
58 \\
26,4 \% \\
5 \\
52,5 \% \\
\\
\\
\\
\\
\\
20 \\
37,7 \% \\
476 \\
33,7 \%\end{array}$ & $\begin{array}{r}213 \\
100,0 \% \\
308 \\
100,0 \% \\
610 \\
100,0 \% \\
220 \\
100,0 \% \\
8 \\
100,0 \%\end{array}$ \\
\hline
\end{tabular}

Verschillen tussen domeinen significant op 5\%-niveau. 
Voorbereiding door HBO: Vermogen om relevante informatie te verzamelen en te interpreteren

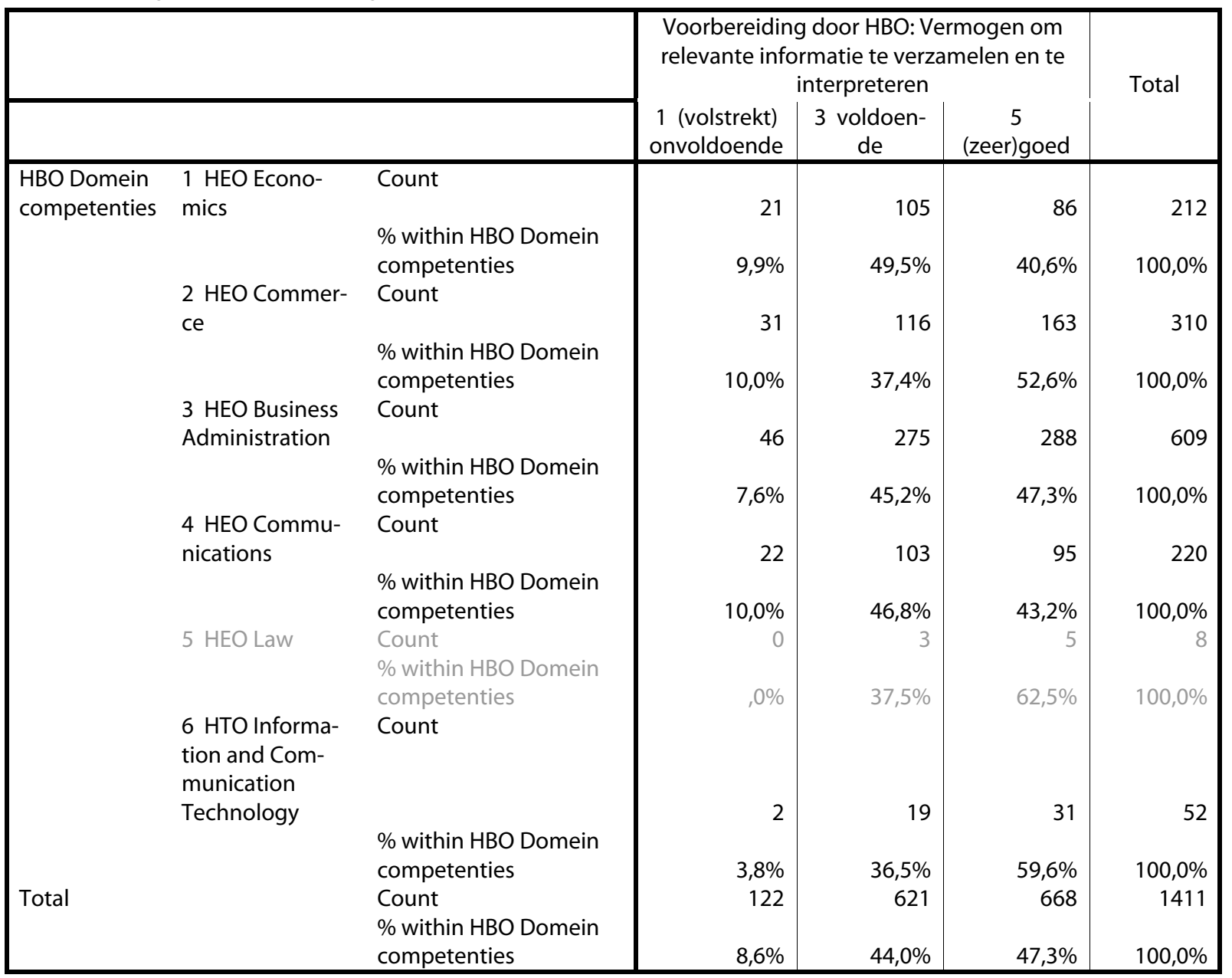


Voorbereiding door HBO: Vermogen om argumenten aan te voeren en te verdiepen

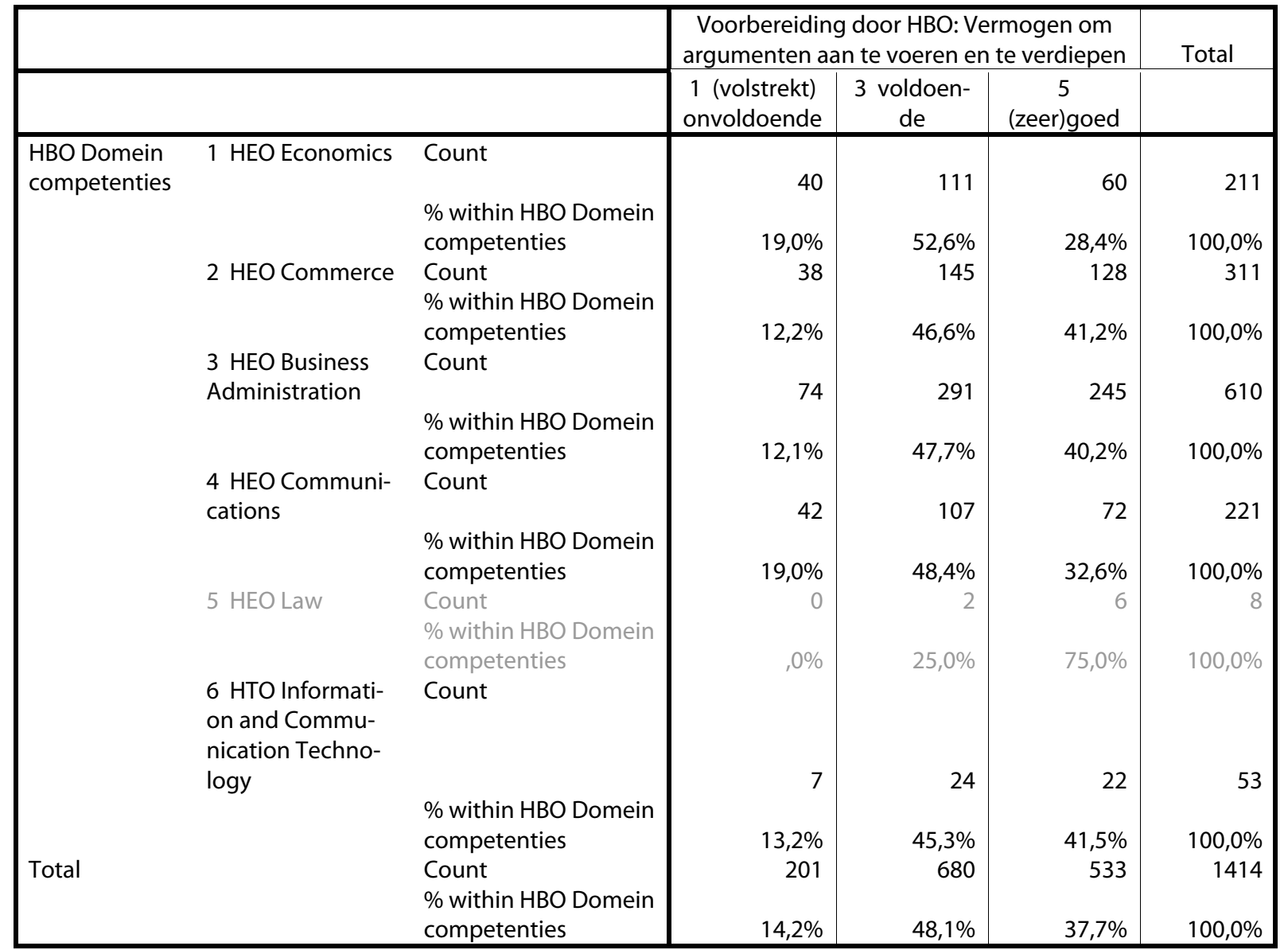

Verschillen tussen domeinen significant op 1\%-niveau. 
Voorbereiding door HBO: Vermogen om een afgewogen oordeel te vormen

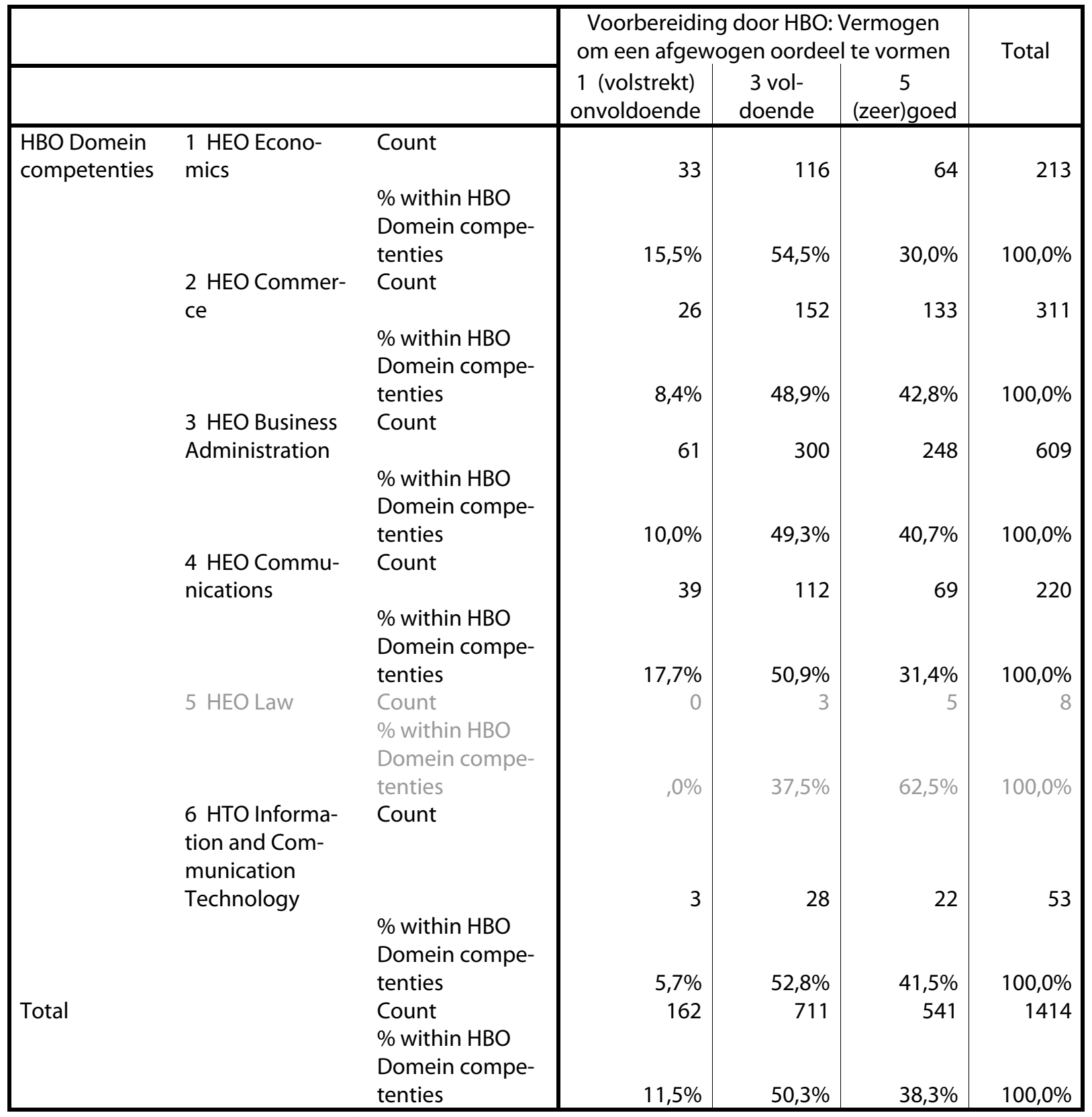

Verschillen tussen domeinen significant op 1\%-niveau. 
Voorbereiding door HBO: Vermogen om aan anderen duidelijk te maken wat $\mathrm{u}$ bedoelt

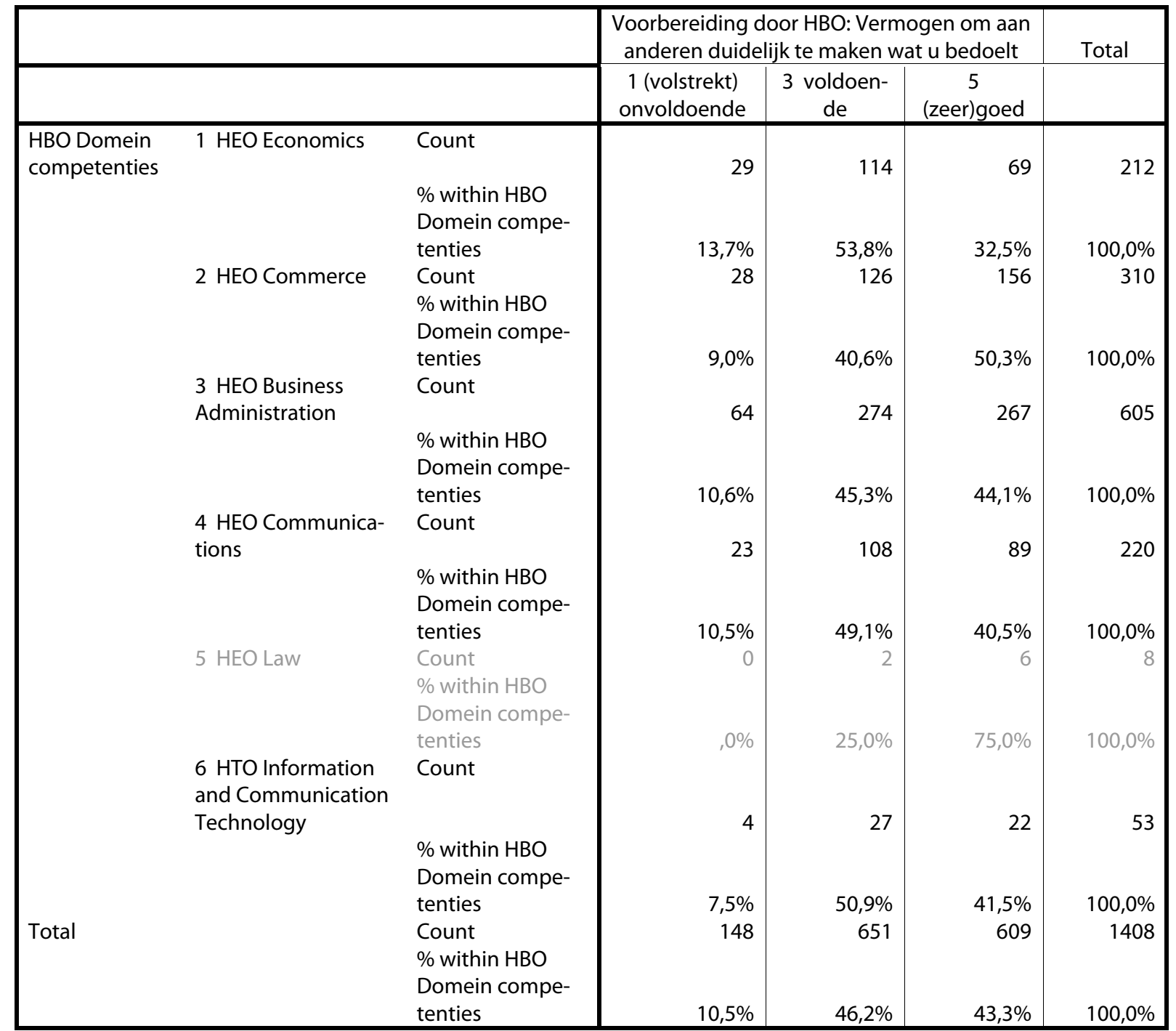

Verschillen tussen domeinen significant op 5\%-niveau. 
Voorbereiding door HBO: Vermogen om uw kennis op een substantieel hoger niveau te brengen

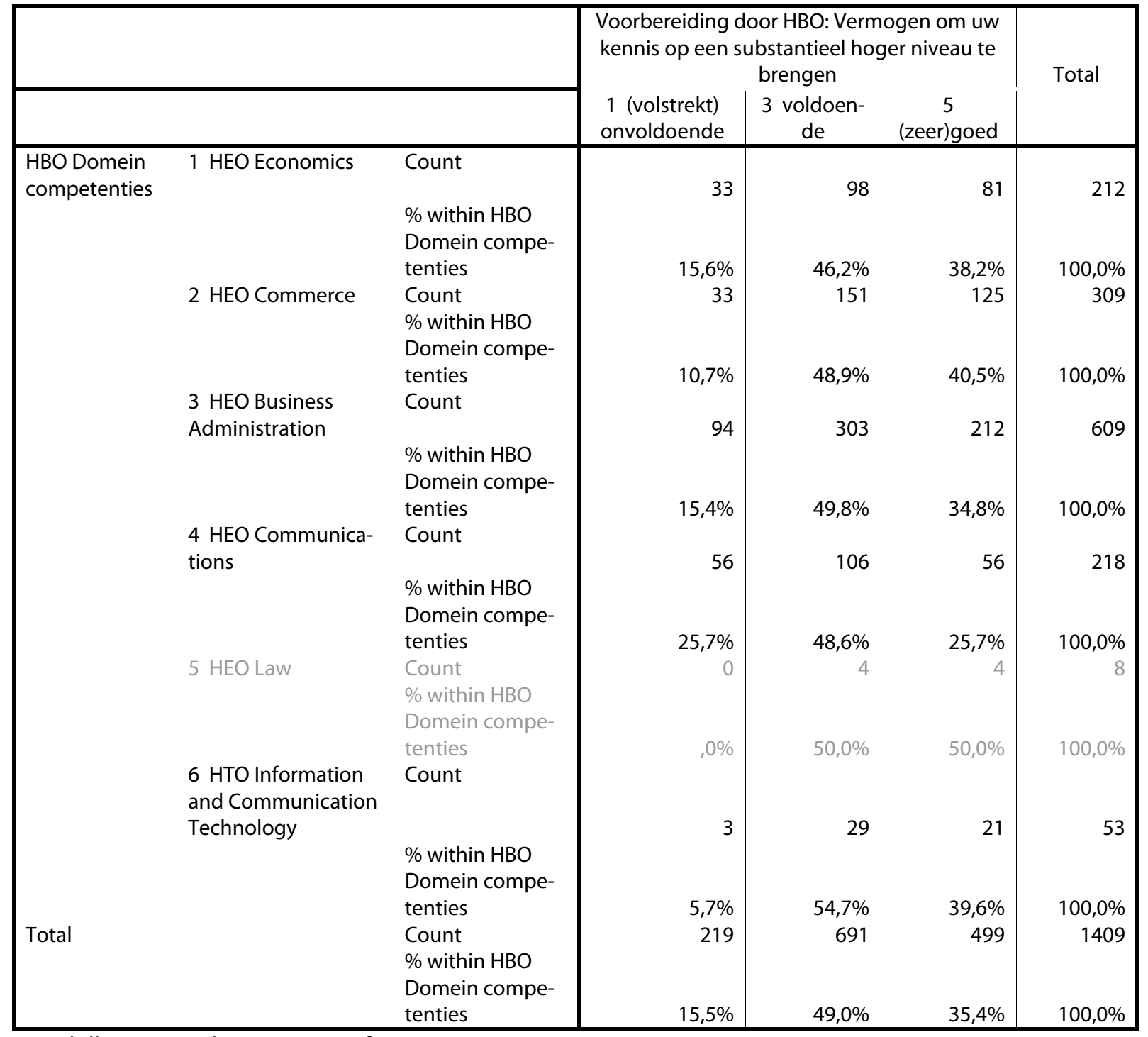

Verschillen tussen domeinen significant op 1\%-niveau. 


\section{Appendix 4: Beschrijvende tabellen van domeincompeten- ties in de pilot}

Het vereiste niveau heeft in deze appendix betrekking op afgestudeerden die in hun kerndomein werken, d.w.z. in een functie die qua vereist opleidingsniveau én vereiste opleidingsrichting aansluit bij de gevolgde $\mathrm{HBO}$-opleiding. Het vereiste niveau is gemeten op een 5-puntschaal ( 1 'matig' <-> 5 'uitmuntend'). De tabellen in deze appendix vermelden het \% laag (antwoordcategorie 1, 2 en 3) en het \% hoog (antwoordcategorie 4 en 5).

De kwaliteit van de voorbereiding door het $\mathrm{HBO}$ heeft betrekking op alle afgestudeerden in de steekproef. De kwaliteit van de voorbereiding is gemeten op een 5puntschaal (1 'volstrekt onvoldoende'; 2 'onvoldoende'; 3 'voldoende' 4 'goed'; 5 'zeer goed'). De tabellen in deze appendix vermelden het \% (volstrekt) onvoldoende (antwoordcategorie 1 en 2), het \% voldoende (antwoordcategorie 3) en het \% (zeer) goed (antwoordcategorie 4 en 5).

De cijfers in grijs in dit hoofdstuk hebben betrekking op minder dan 20 respondenten.

\subsection{Economics}

Opleidingen in de steekproef

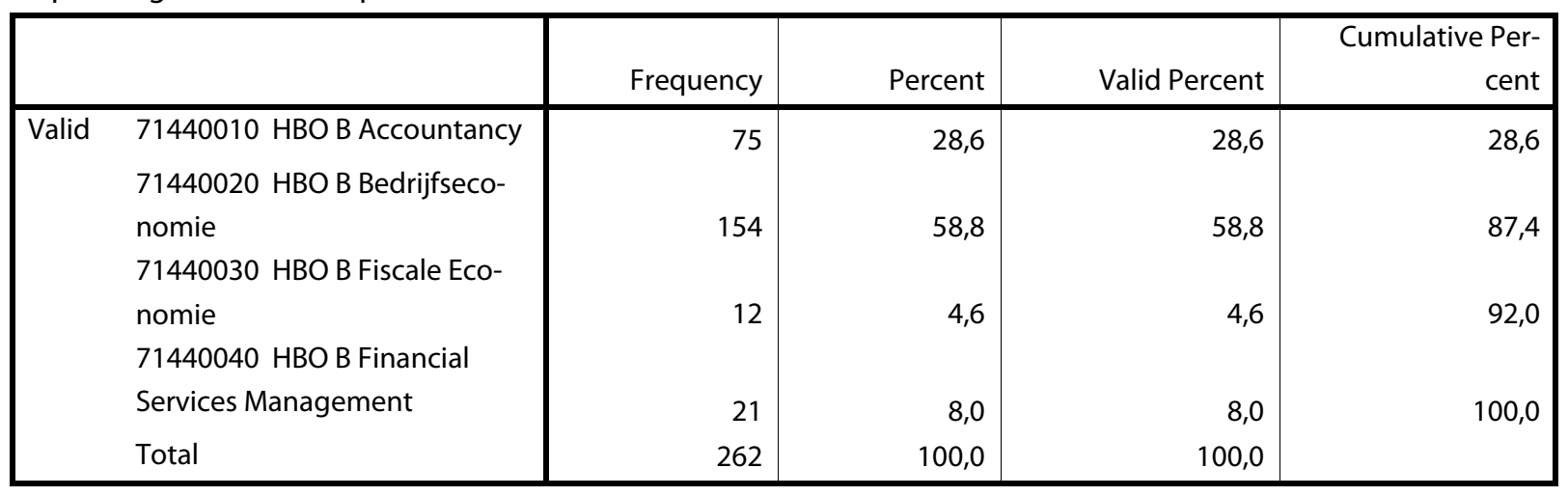




\subsubsection{Vereist niveau (Economics)}

\section{Beheersing informatiesystemen}

Ontwerpen, inrichten en onderhouden van (geautomatiseerde) informatiesystemen voor het besturen van organisaties

\begin{tabular}{|c|c|c|c|c|c|}
\hline & & & \multicolumn{2}{|c|}{$\begin{array}{l}\text { Comp. VN: ontwerpen, inrich- } \\
\text { ten, onderhouden in- } \\
\text { fo.systeem }\end{array}$} & \multirow[b]{2}{*}{ Total } \\
\hline & & & 1 laag & 5 hoog & \\
\hline \multirow{12}{*}{$\begin{array}{l}\text { Adm. codenr.: } \\
\text { opleidingsrichting }\end{array}$} & 71440010 HBO B Ac- & Count & 21 & 37 & 58 \\
\hline & countancy & $\%$ within Adm. codenr.: & & & \\
\hline & & opleidingsrichting & $36,2 \%$ & $63,8 \%$ & $100,0 \%$ \\
\hline & 71440020 HBO B Be- & Count & 32 & 44 & 76 \\
\hline & drijfseconomie & \% within Adm. codenr.: & & & \\
\hline & & opleidingsrichting & $42,1 \%$ & $57,9 \%$ & $100,0 \%$ \\
\hline & 71440030 HBO B Fiscale & Count & 2 & 1 & 3 \\
\hline & Economie & $\%$ within Adm. codenr.: & & & \\
\hline & & opleidingsrichting & $66,7 \%$ & $33,3 \%$ & $100,0 \%$ \\
\hline & 71440040 HBO B Financi- & Count & 3 & 3 & 6 \\
\hline & al Services Management & $\%$ within Adm. codenr.: & & & \\
\hline & & opleidingsrichting & $50,0 \%$ & $50,0 \%$ & $100,0 \%$ \\
\hline \multirow[t]{3}{*}{ Total } & & Count & 58 & 85 & 143 \\
\hline & & \% within Adm. codenr.: & & & \\
\hline & & opleidingsrichting & $40,6 \%$ & $59,4 \%$ & $100,0 \%$ \\
\hline
\end{tabular}

\section{Beheersing administratieve organisatie}

Vormgeven, inrichten en toetsen van de administratieve organisatie

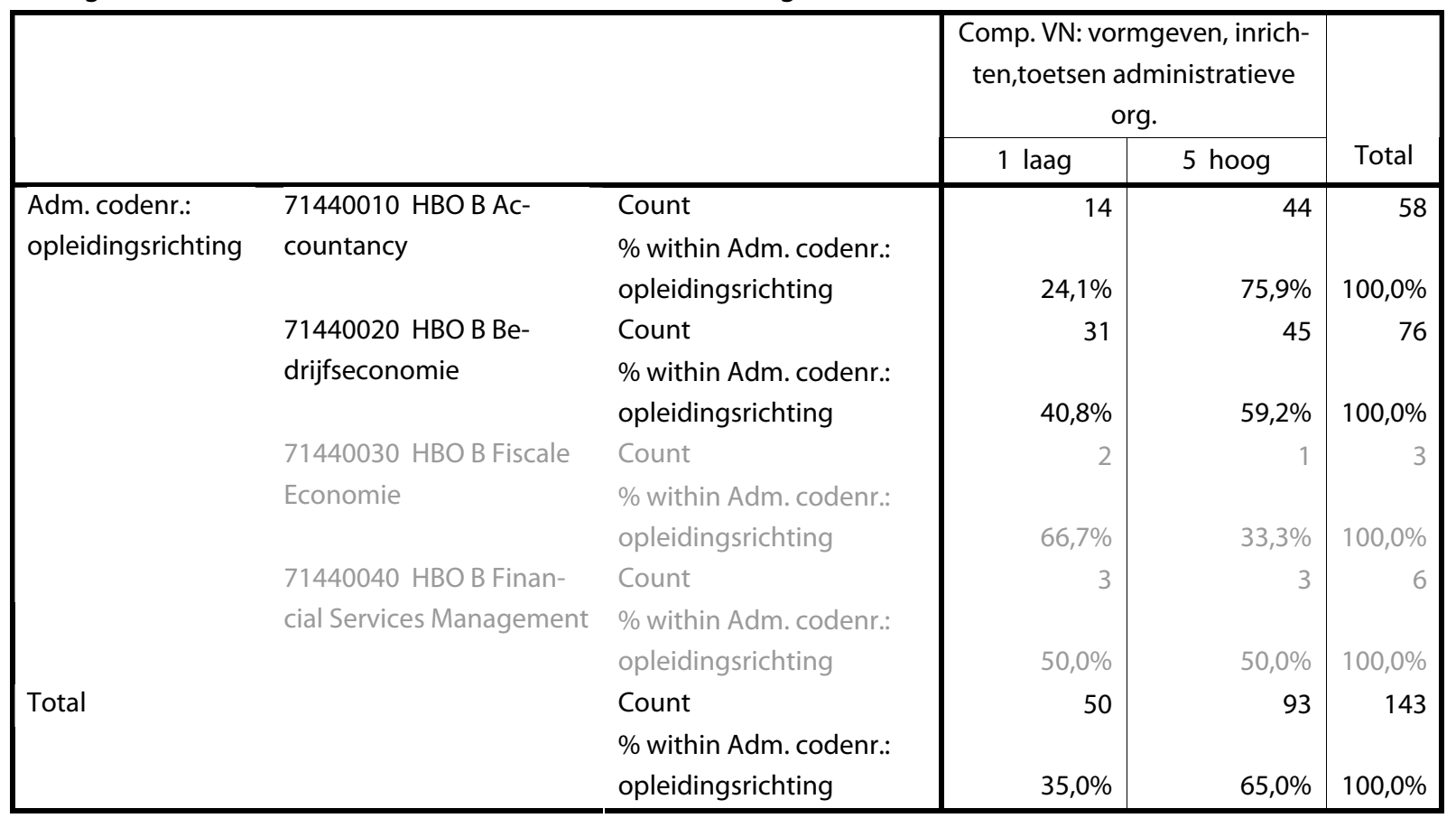




\section{Beheersing financieel-economische en fiscale risico's}

Bepalen en beheersen van financieel-economische en fiscale risico's

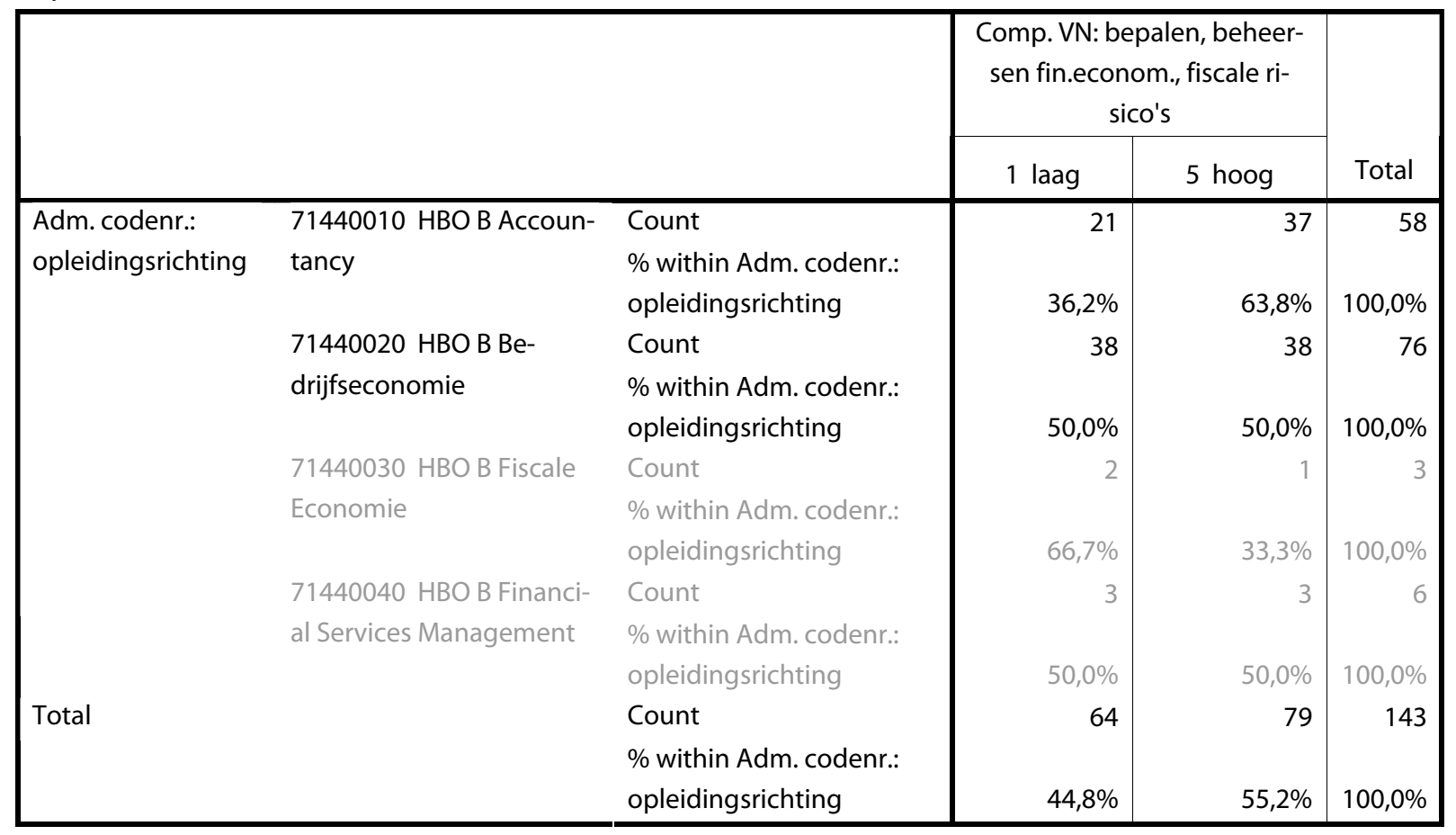

\section{Verstrekken van financieel-economische en fiscale informatie}

Bepalen en verstrekken van financieel-economische en fiscale informatie voor besluitvorming

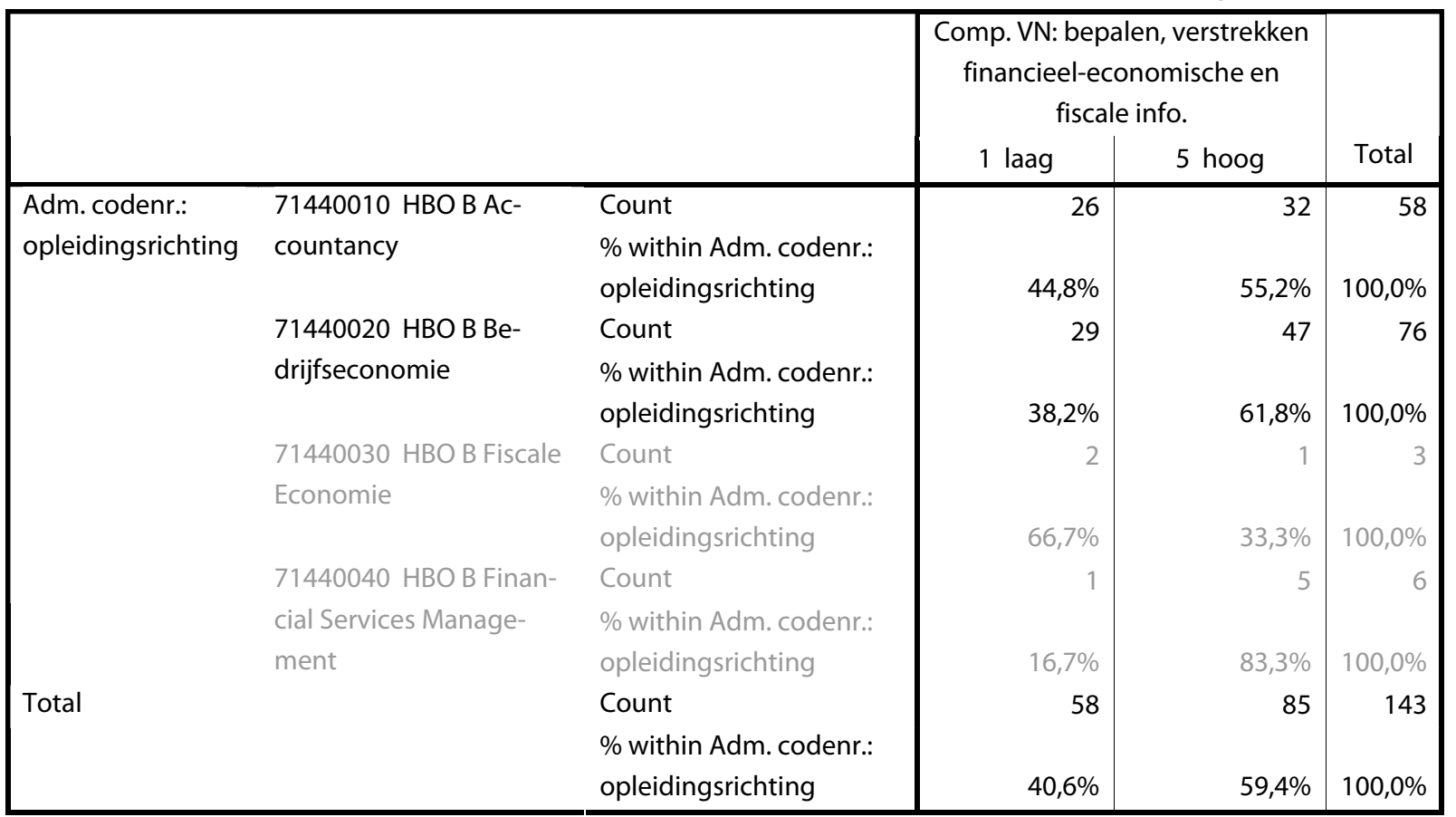




\section{Extern verstrekken van informatie}

Verstrekken van informatie ten behoeve van externe belanghebbenden

\begin{tabular}{|c|c|c|c|c|c|}
\hline & & & $\begin{array}{l}\text { Comp. VN:ve } \\
\text { Externe bela }\end{array}$ & $\begin{array}{l}\text { ekken info. } \\
\text { ebbenden }\end{array}$ & \\
\hline & & & 1 laag & 5 hoog & Total \\
\hline Adm. codenr.: & 71440010 HBO B AC- & Count & 20 & 38 & 58 \\
\hline opleidingsrichting & countancy & \% within Adm. codenr.: & & & \\
\hline & & opleidingsrichting & $34,5 \%$ & $65,5 \%$ & $100,0 \%$ \\
\hline & 71440020 HBO B Be- & Count & 29 & 46 & 75 \\
\hline & drijfseconomie & \% within Adm. codenr.: & & & \\
\hline & & opleidingsrichting & $38,7 \%$ & $61,3 \%$ & $100,0 \%$ \\
\hline & 71440030 HBO B Fiscale & Count & 2 & 1 & 3 \\
\hline & Economie & $\%$ within Adm. codenr.: & & & \\
\hline & & opleidingsrichting & $66,7 \%$ & $33,3 \%$ & $100,0 \%$ \\
\hline & 71440040 HBO B Finan- & Count & 3 & 3 & 6 \\
\hline & cial Services Manage- & $\%$ within Adm. codenr.: & & & \\
\hline & ment & opleidingsrichting & $50,0 \%$ & $50,0 \%$ & $100,0 \%$ \\
\hline Total & & Count & 54 & 88 & 142 \\
\hline & & \% within Adm. codenr.: & & & \\
\hline & & opleidingsrichting & $38,0 \%$ & $62,0 \%$ & $100,0 \%$ \\
\hline
\end{tabular}

\section{Adviseren op financieel-economisch en fiscaal terrein}

Geven van adviezen en verlenen van diensten op financieel-economisch en fiscaal terrein aan belanghebbenden

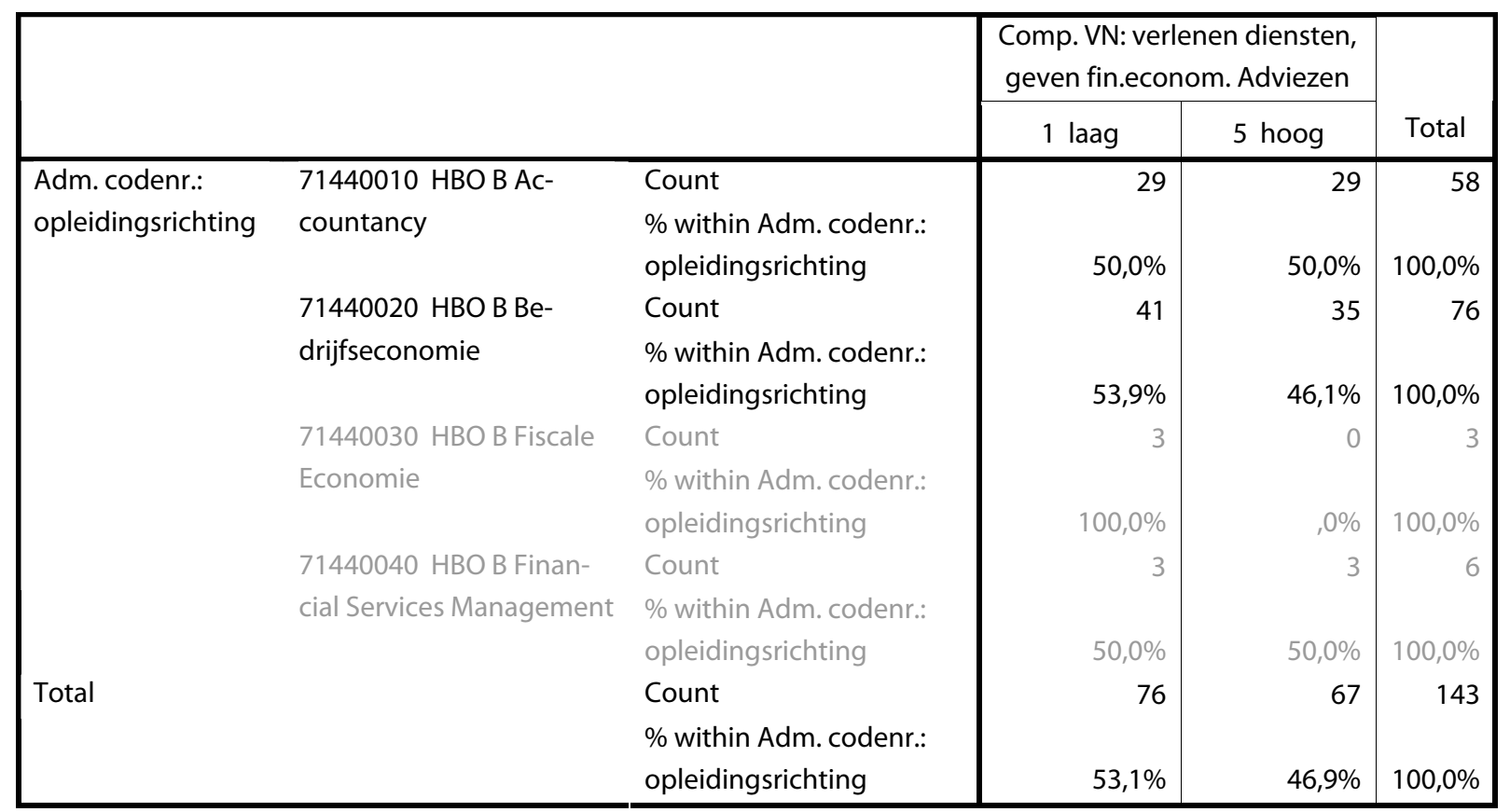




\subsubsection{Voorbereiding door hbo (Economics)}

\section{Beheersing informatiesystemen}

Ontwerpen, inrichten en onderhouden van (geautomatiseerde) informatiesystemen voor het besturen van organisaties

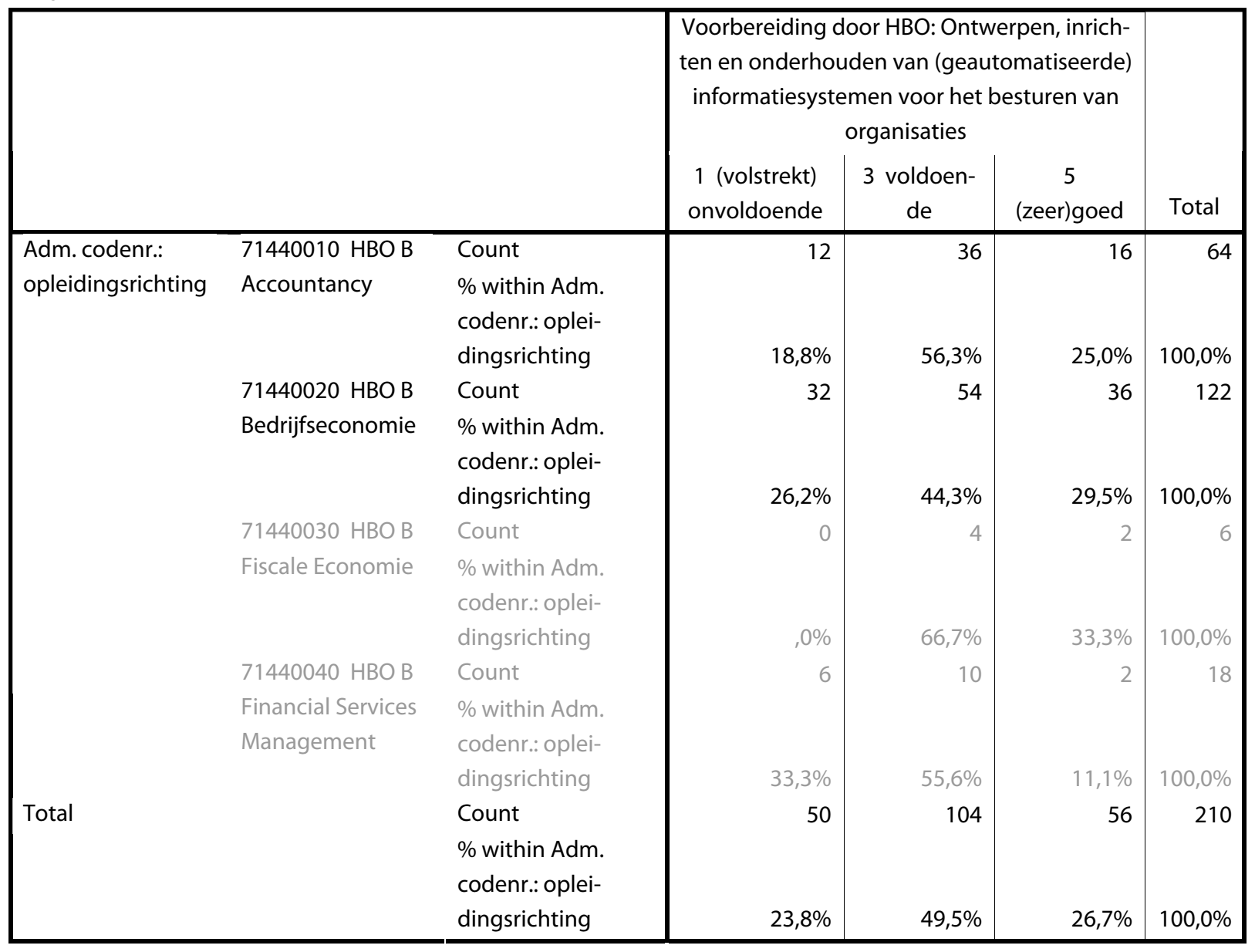




\section{Beheersing administratieve organisatie}

Vormgeven, inrichten en toetsen van de administratieve organisatie

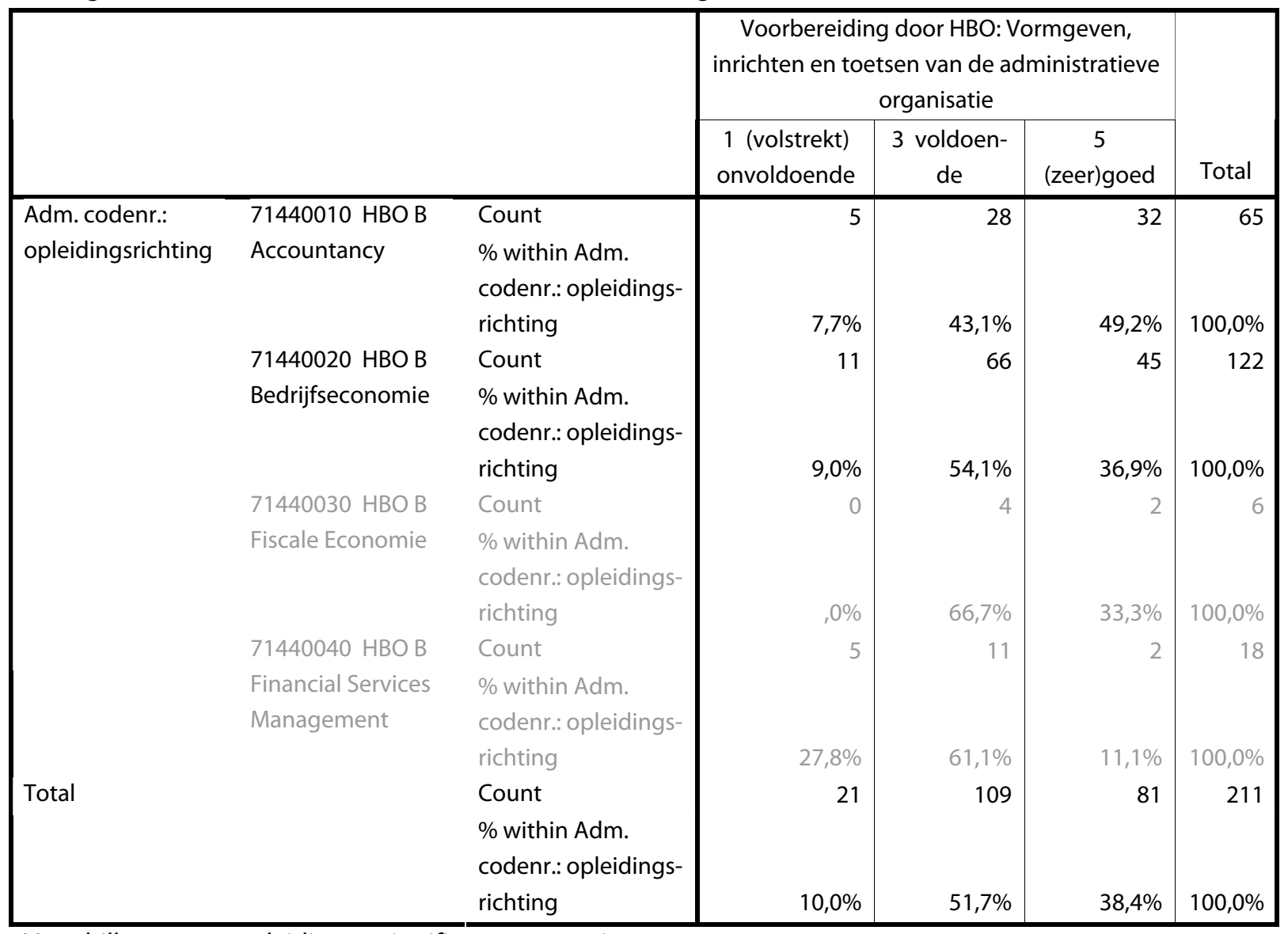

Verschillen tussen opleidingen significant op 5\%-niveau. 


\section{Beheersing financieel-economische en fiscale risico's}

Bepalen en beheersen van financieel-economische en fiscale risico's

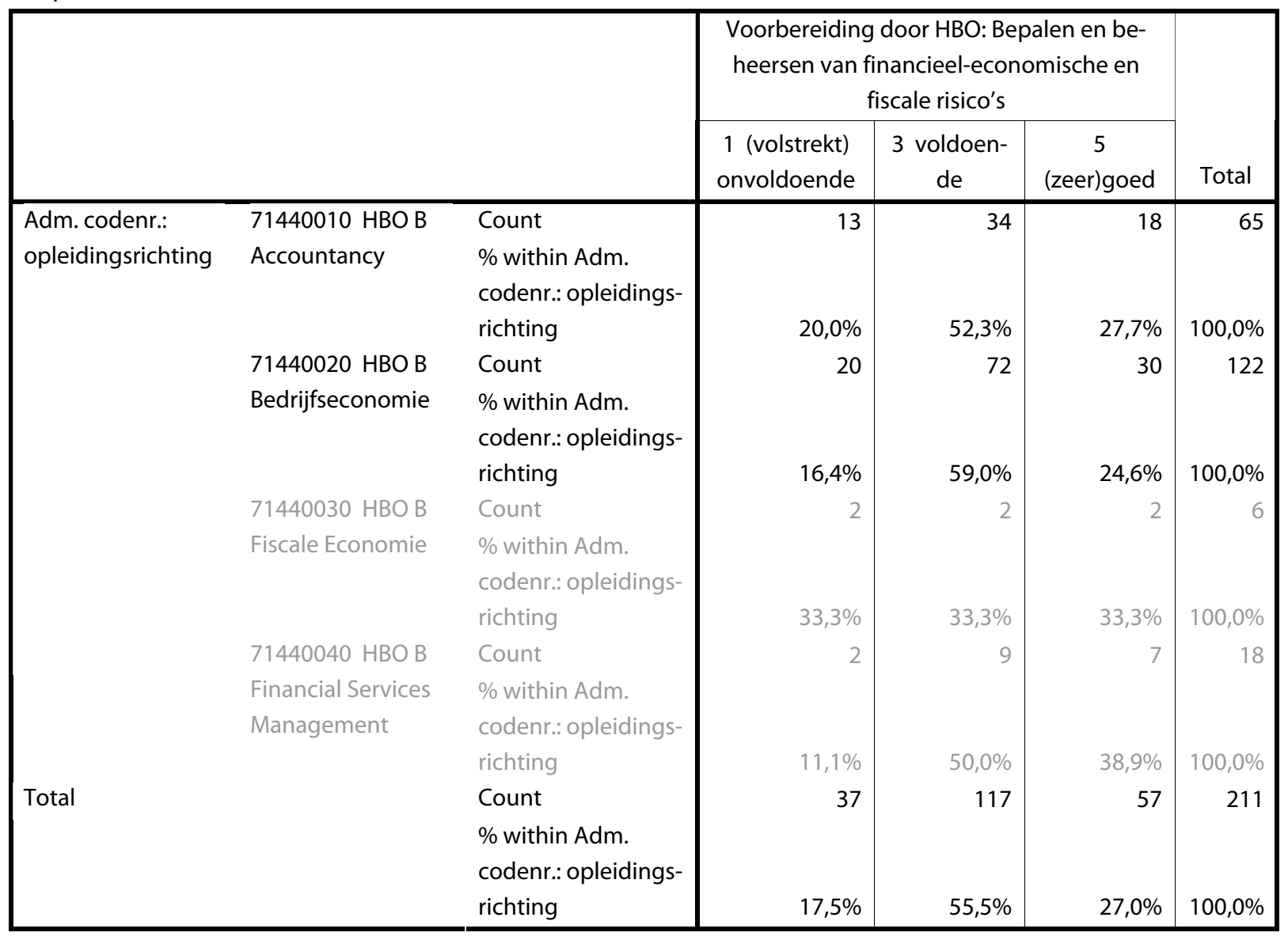


Verstrekken van financieel-economische en fiscale informatie

Bepalen en verstrekken van financieel-economische en fiscale informatie voor besluitvorming

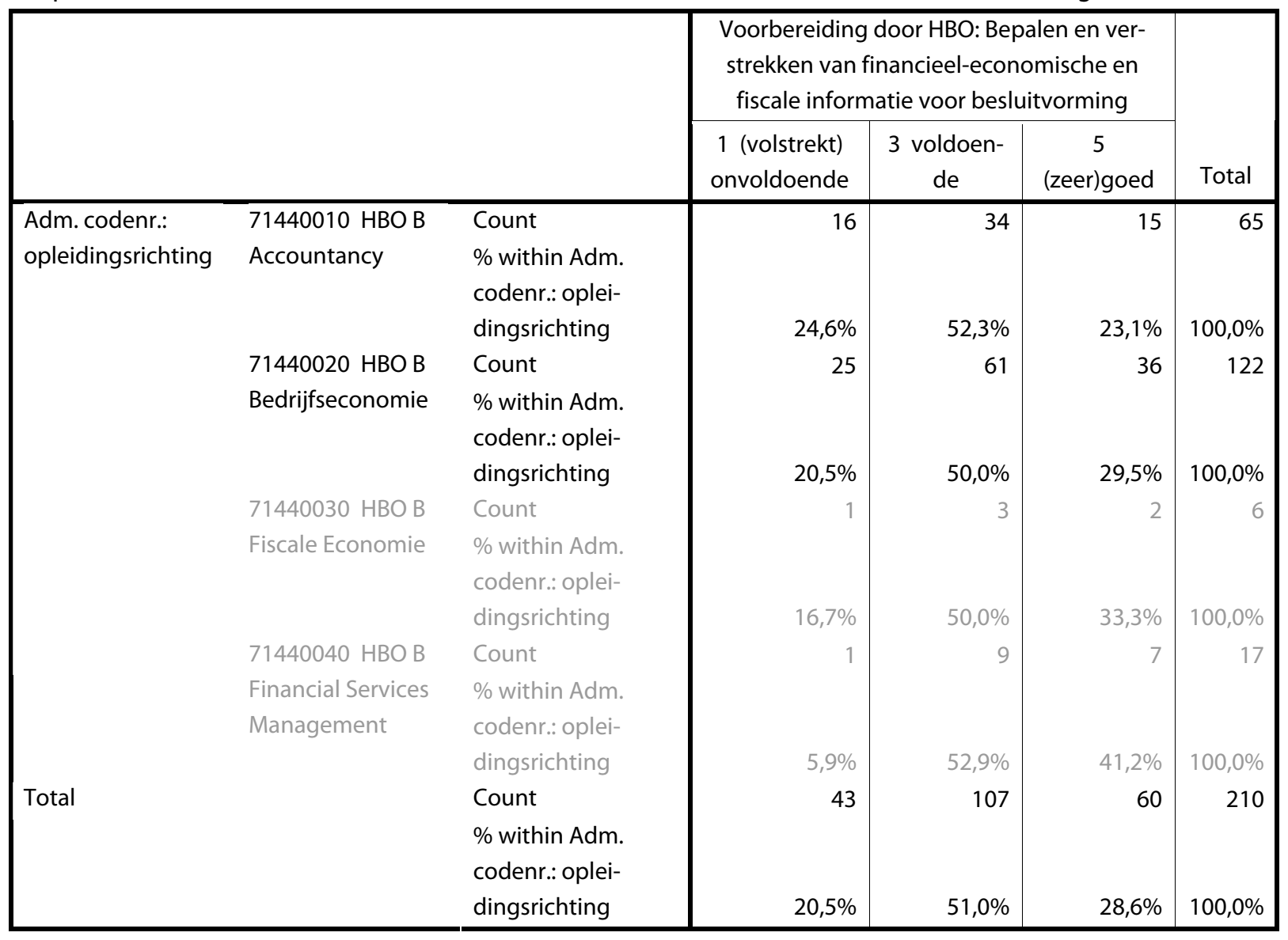




\section{Extern verstrekken van informatie}

Verstrekken van informatie ten behoeve van externe belanghebbenden

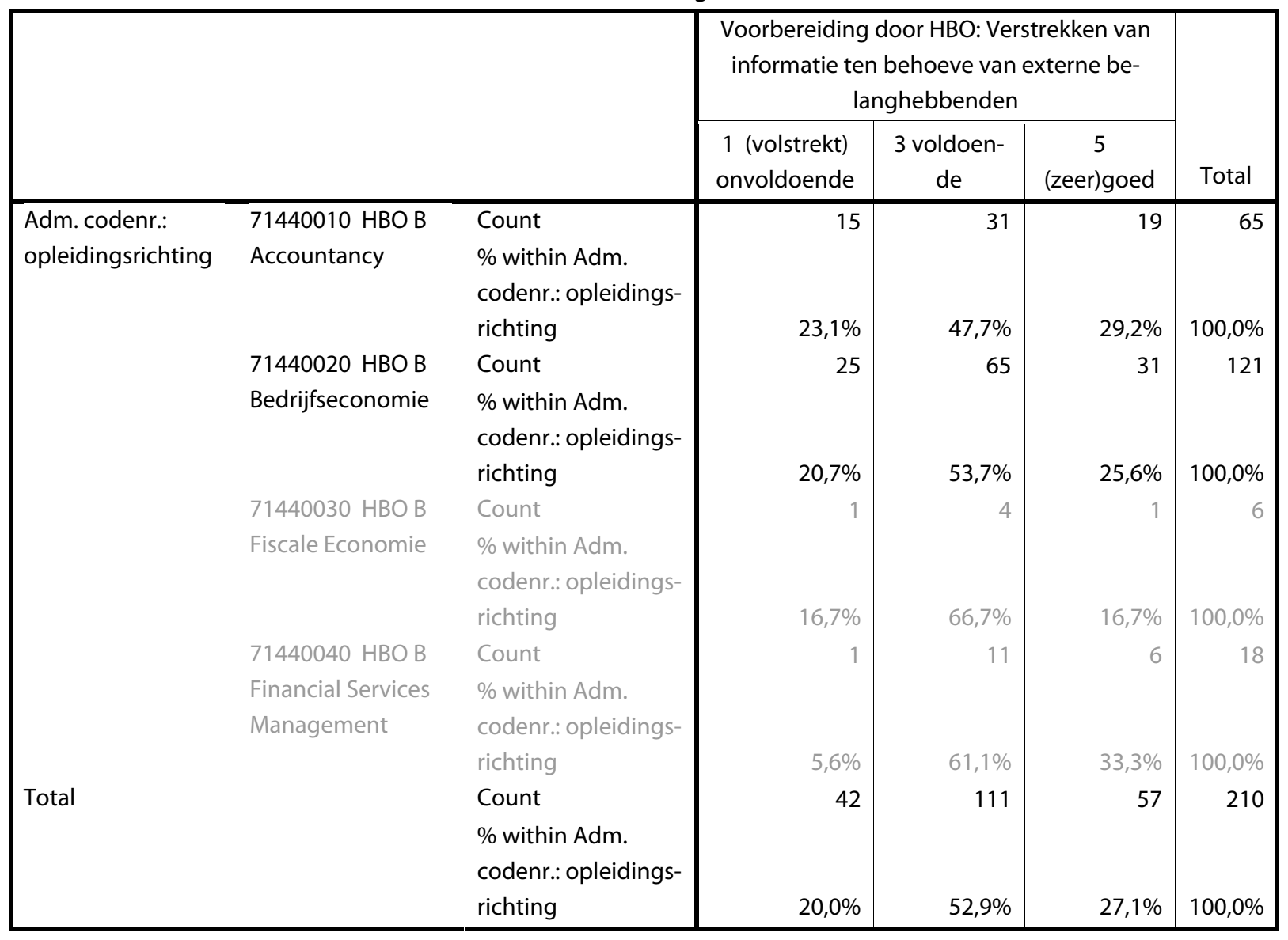




\section{Adviseren op financieel-economisch en fiscaal terrein}

Geven van adviezen en verlenen van diensten op financieel-economisch en fiscaal terrein aan belanghebbenden

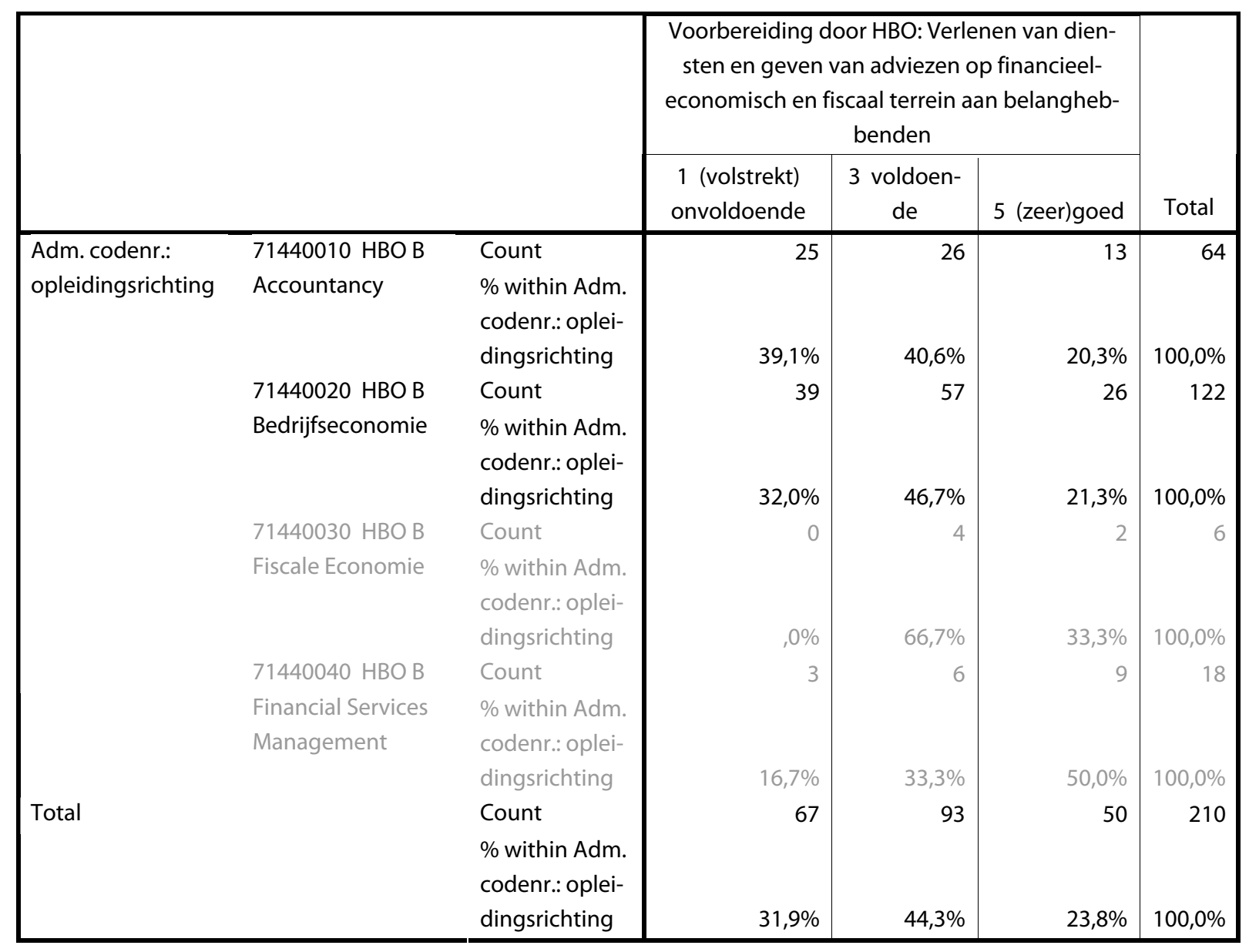

\subsection{Commerce}

Opleidingen in de steekproef

\begin{tabular}{|c|c|c|c|c|c|}
\hline & & Frequency & Percent & Valid Percent & $\begin{array}{r}\text { Cumulative Per- } \\
\text { cent }\end{array}$ \\
\hline Valid & $\begin{array}{l}71440180 \text { HBO B Commerciële } \\
\text { Economie } \\
71440190 \text { HBO B Trade Manage- } \\
\text { ment gericht op Azië } \\
71440220 \text { HBO B International } \\
\text { Business and Languages } \\
71440230 \text { HBO B Small Business } \\
\text { en Retail Management } \\
71440240 \text { HBO B Food \& Business } \\
\text { Total }\end{array}$ & $\begin{array}{r}6 \\
28 \\
50 \\
10 \\
379\end{array}$ & $\begin{array}{r}1,6 \\
7,4\end{array}$ & $\begin{array}{r}13,2 \\
2,6 \\
100,0\end{array}$ & $\begin{array}{l}75,2 \\
76,8 \\
84,2 \\
97,4 \\
100,0\end{array}$ \\
\hline
\end{tabular}




\subsubsection{Vereist niveau (Commerce)}

\section{Creëren producten en diensten}

Initiëren en creëren van producten en diensten, zelfstandig en ondernemend

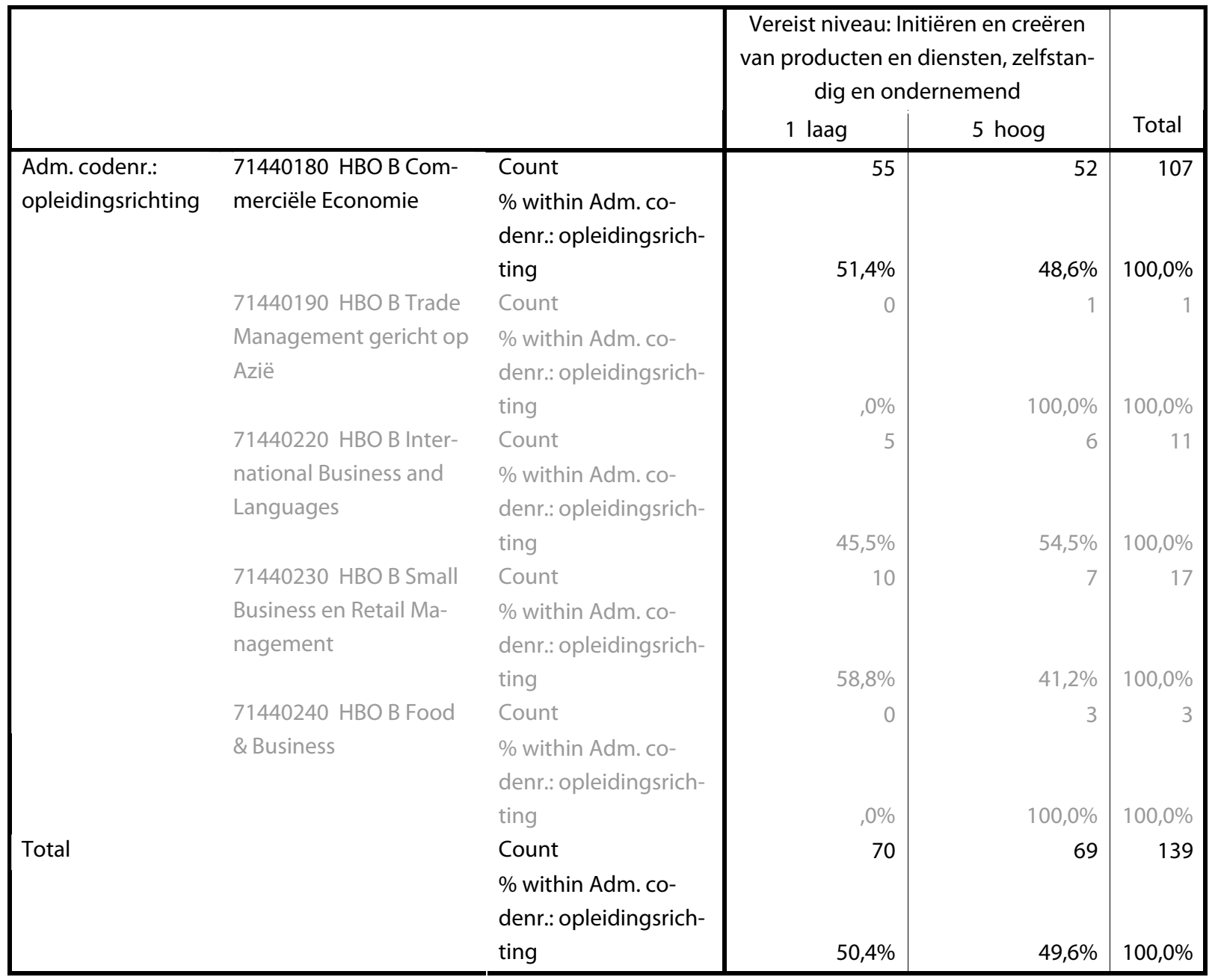




\section{Beheersing marktonderzoek}

Uitvoeren, interpreteren, toetsen en evalueren van marktonderzoek

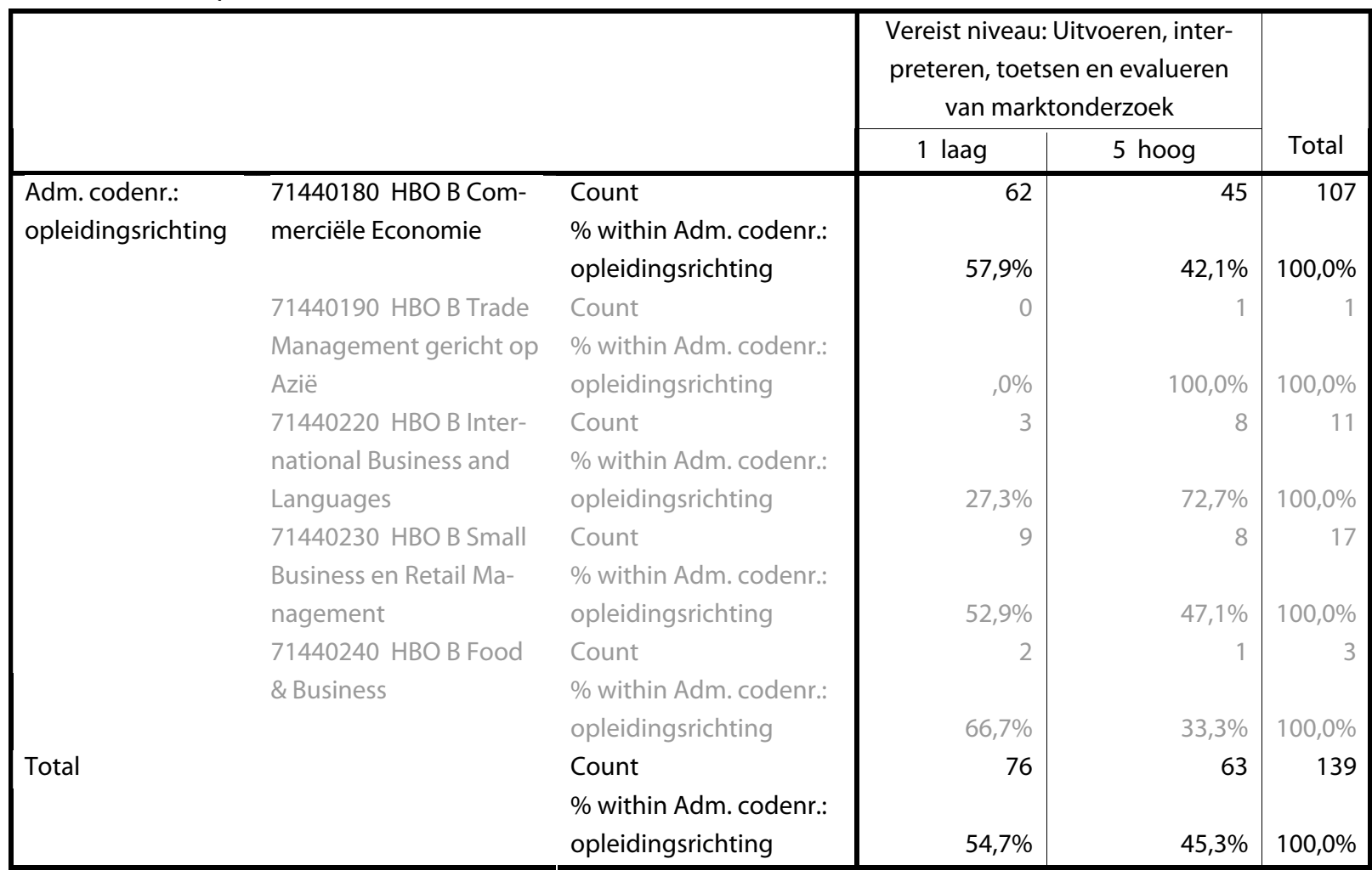




\section{Analyse interne en externe omgeving}

Vaststellen voor een onderneming van enerzijds de sterktes en zwaktes op basis van een analyse van de interne bedrijfsprocessen en -cultuur, als onderdeel van de waardeketen, en anderzijds van de kansen en bedreigingen op de lokale, nationale en/of internationale markt op basis van relevante nationale en internationale trends

\begin{tabular}{|c|c|c|c|c|c|}
\hline & & & $\begin{array}{l}\text { Vereist niveau: Vast } \\
\text { neming van enerzijd } \\
\text { op basis van een an } \\
\text { drijfsprocessen en -c } \\
1 \text { laag }\end{array}$ & $\begin{array}{l}\text { oor een onder- } \\
\text { ktes en zwaktes } \\
\text { n de interne be- } \\
5 \text { hoog }\end{array}$ & Total \\
\hline \multirow[t]{11}{*}{$\begin{array}{l}\text { Adm. codenr.: } \\
\text { opleidingsrichting }\end{array}$} & $\begin{array}{l}71440180 \text { HBO B } \\
\text { Commerciële Econo- } \\
\text { mie }\end{array}$ & $\begin{array}{l}\text { Count } \\
\text { \% within Adm. } \\
\text { codenr.: oplei- } \\
\text { dingsrichting }\end{array}$ & $402 \%$ & 64 & $1000 \%$ \\
\hline & $\begin{array}{l}71440190 \text { HBO B } \\
\text { Trade Management } \\
\text { gericht op Azië }\end{array}$ & $\begin{array}{l}\text { Count } \\
\text { \% within Adm. } \\
\text { codenr.: oplei- }\end{array}$ & 0 & 1 & 1 \\
\hline & & dingsrichting & ,0\% & $100,0 \%$ & $100,0 \%$ \\
\hline & $\begin{array}{l}71440220 \mathrm{HBO} \text { B } \\
\text { International Business } \\
\text { and Languages }\end{array}$ & $\begin{array}{l}\text { Count } \\
\% \text { within Adm. } \\
\text { codenr.: oplei- }\end{array}$ & 1 & 10 & 11 \\
\hline & & dingsrichting & $9,1 \%$ & $90,9 \%$ & $100,0 \%$ \\
\hline & 71440230 HBO В & Count & 7 & 10 & 17 \\
\hline & $\begin{array}{l}\text { Small Business en } \\
\text { Retail Management }\end{array}$ & $\begin{array}{l}\% \text { within Adm. } \\
\text { codenr.: oplei- }\end{array}$ & & & \\
\hline & & dingsrichting & $41,2 \%$ & $58,8 \%$ & $100,0 \%$ \\
\hline & 71440240 HВO В & Count & 0 & 3 & 3 \\
\hline & Food \& Business & $\begin{array}{l}\% \text { within Adm. } \\
\text { codenr.: oplei- }\end{array}$ & & & \\
\hline & & dingsrichting &, $0 \%$ & $100,0 \%$ & $100,0 \%$ \\
\hline \multirow[t]{3}{*}{ Total } & & Count & 51 & 88 & 139 \\
\hline & & $\%$ within Adm. & & & \\
\hline & & dingsrichting & $36,7 \%$ & $63,3 \%$ & $100,0 \%$ \\
\hline
\end{tabular}




\section{Ontwikkelen marketingbeleid}

Ontwikkelen van marketingbeleid (ondernemingsbeleid) voor een nationaal of internationaal opererende onderneming en het kunnen onderbouwen en beargumenteren van gemaakte keuzes

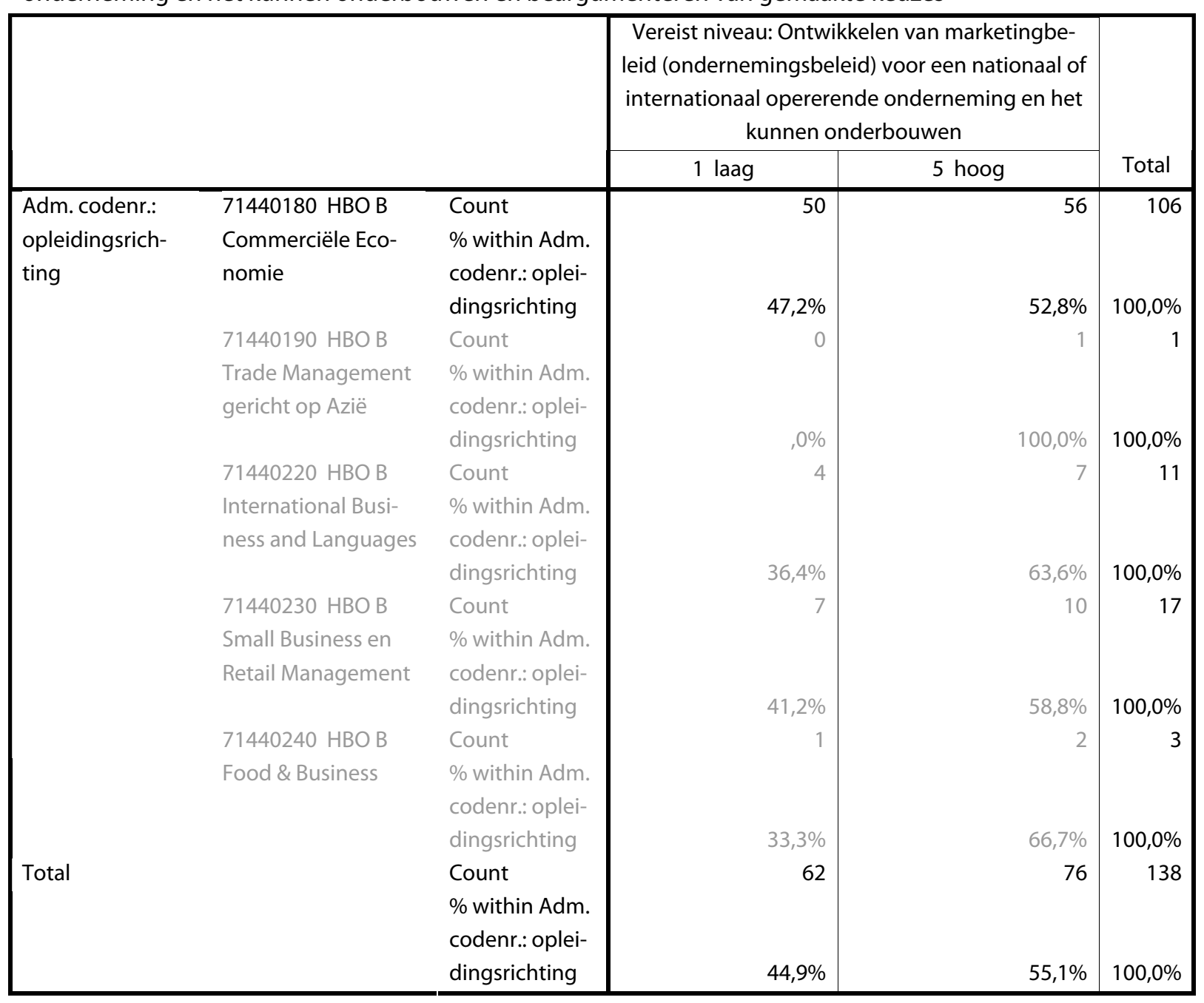




\section{Implementatie marketingbeleid}

Opstellen, uitvoeren en bijstellen van plannen vanuit het marketingbeleid (ondernemingsbeleid)

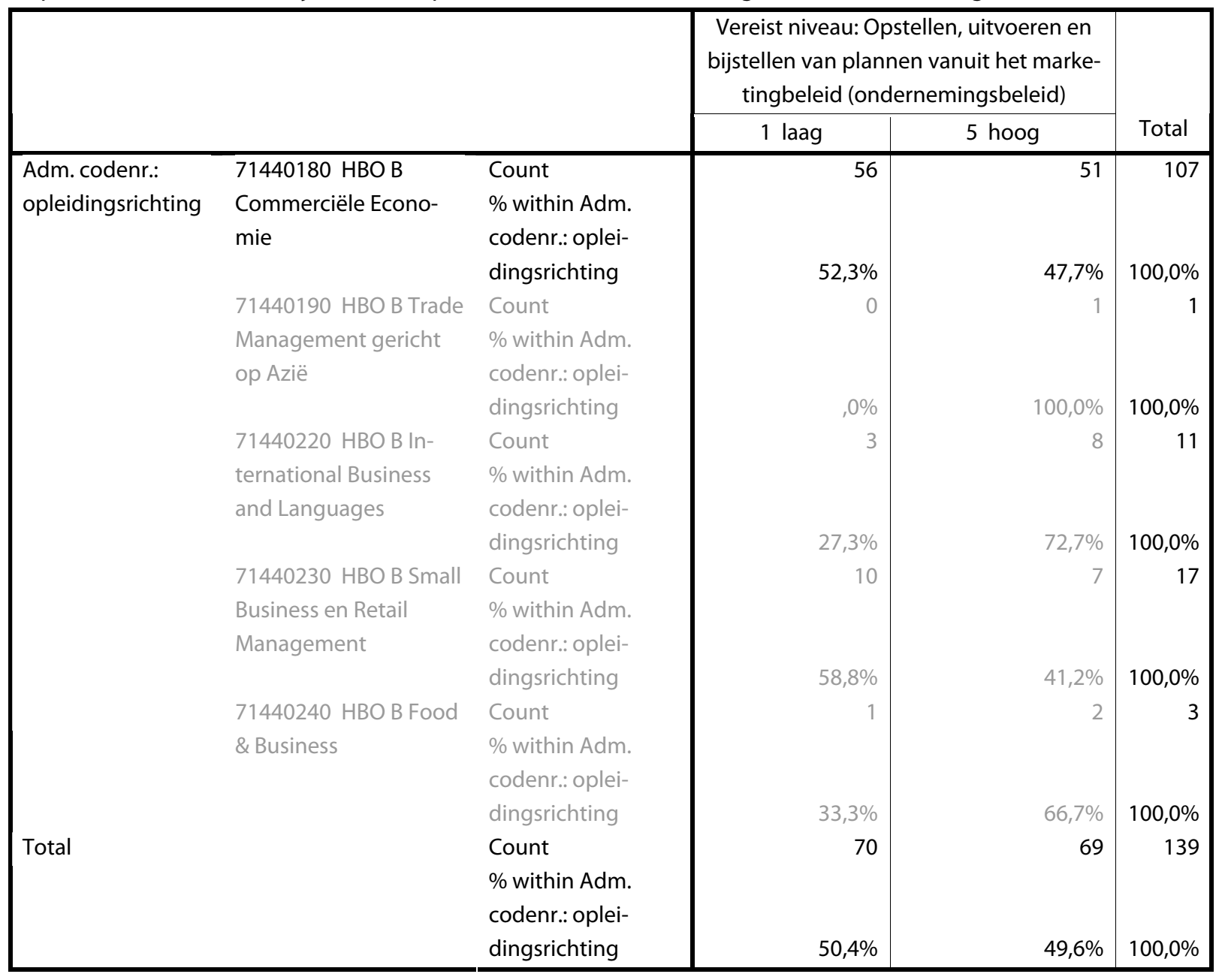




\section{Zakelijke relaties onderhouden}

Ontwikkelen en onderhouden van zakelijke relaties ten behoeve van inkoop, verkoop en dienstverlening

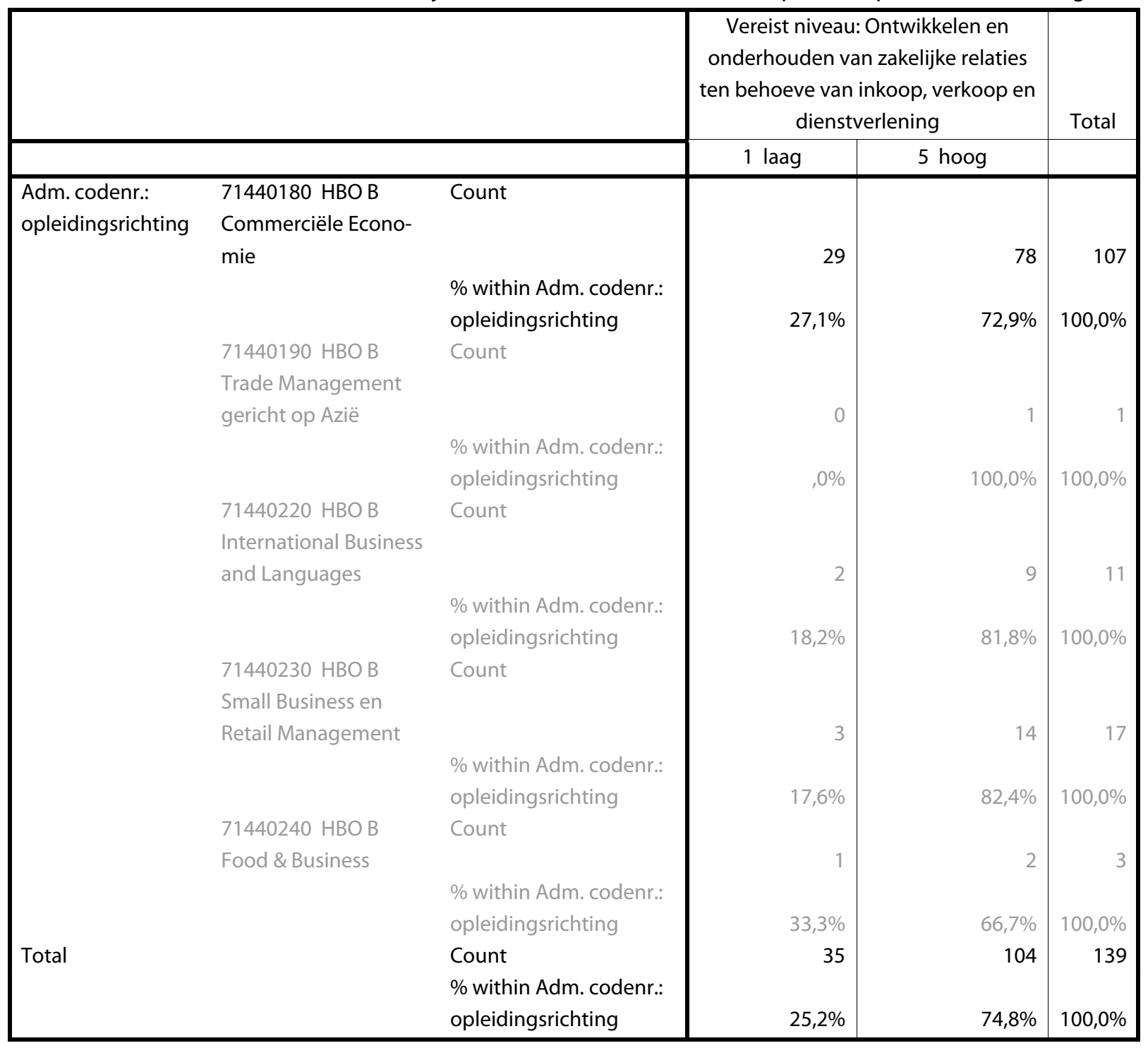




\section{Communiceren in interculturele context}

Communiceren in meer talen en rekening houdend met culturele verschillen, intern en extern, nationaal en internationaal

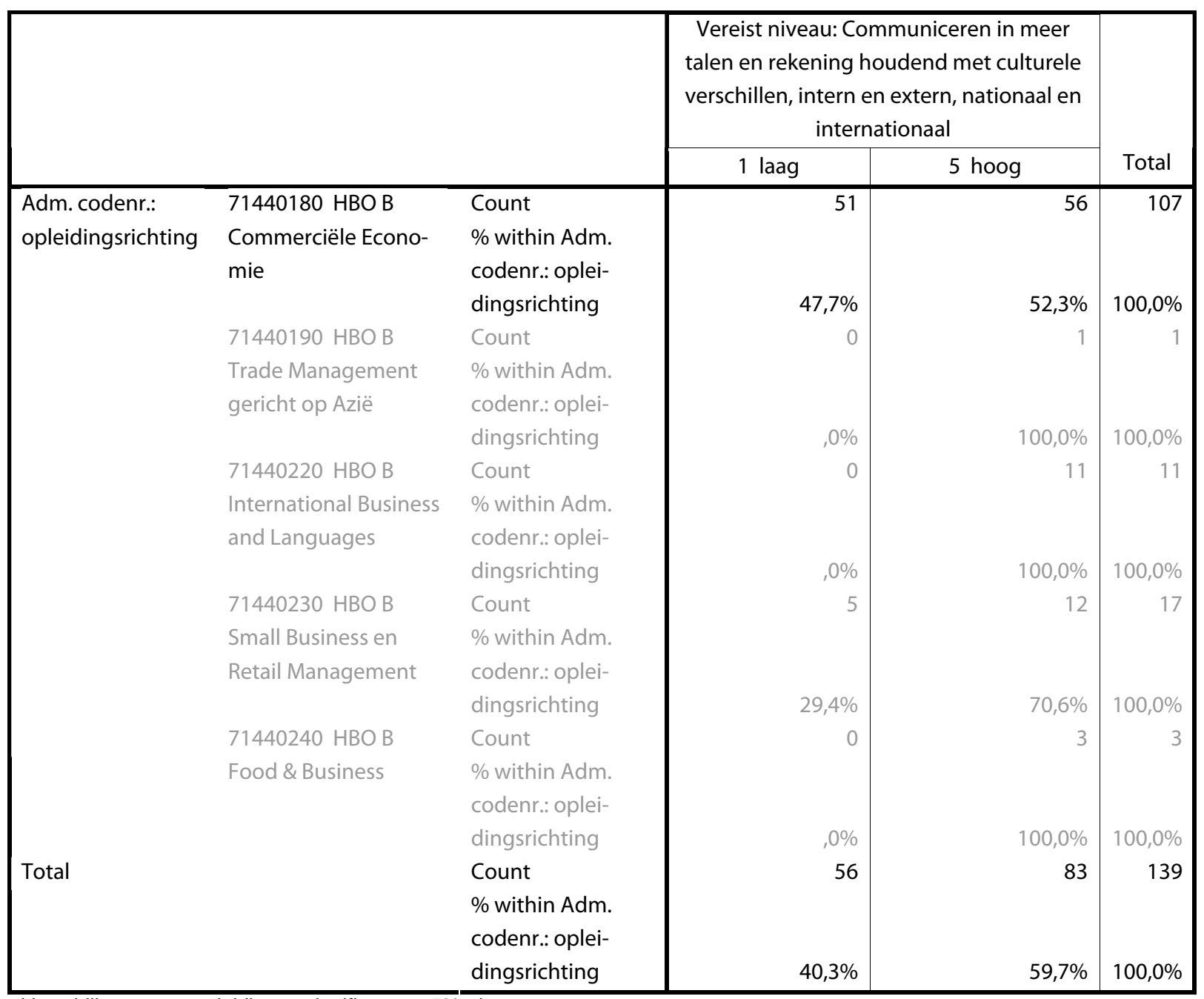

Verschillen tussen opleidingen significant op 5\%-niveau. 


\section{Leiding geven}

Leiding geven aan een bedrijf, een bedrijfsonderdeel, bedrijfsprocessen of een project

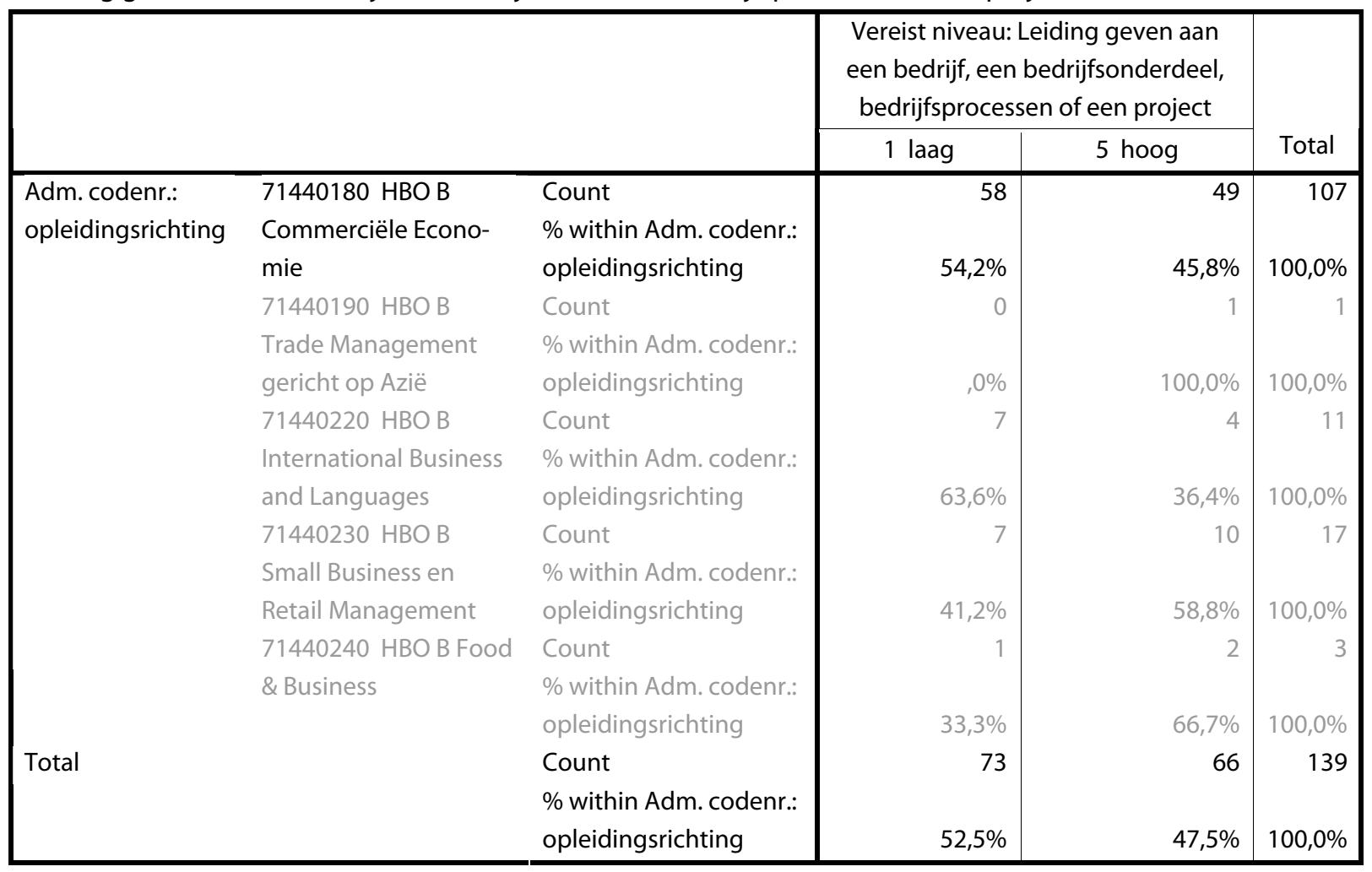




\subsubsection{Voorbereiding door hbo (Commerce)}

\section{Creëren producten en diensten}

Initiëren en creëren van producten en diensten, zelfstandig en ondernemend

\begin{tabular}{|c|c|c|c|c|c|c|}
\hline \multirow{2}{*}{$\begin{array}{l} \\
\\
\text { Adm. codenr.: } \\
\text { opleidingsrich- } \\
\text { ting }\end{array}$} & \multirow[b]{2}{*}{$\begin{array}{l}71440180 \mathrm{HBO} \mathrm{B} \\
\text { Commerciële Eco- } \\
\text { nomie }\end{array}$} & \multirow[b]{2}{*}{$\begin{array}{l}\text { Count } \\
\text { \% within Adm. } \\
\text { codenr.: oplei- } \\
\text { dingsrichting }\end{array}$} & \multicolumn{3}{|c|}{$\begin{array}{l}\text { Voorbereiding door HBO: Initiëren en creëren } \\
\text { van producten en diensten, zelfstandig en on- } \\
\text { dernemend }\end{array}$} & Total \\
\hline & & & 39 & 127 & 58 & 224 \\
\hline & $\begin{array}{l}71440190 \text { HBO B } \\
\text { Trade Management } \\
\text { gericht op Azië }\end{array}$ & $\begin{array}{l}\text { Count } \\
\% \text { within Adm. } \\
\text { codenr.: oplei- } \\
\text { dingsrichting }\end{array}$ & $\begin{array}{r}2 \\
40,0 \%\end{array}$ & $60,0 \%$ &, $0 \%$ & $100,0 \%$ \\
\hline & $\begin{array}{l}71440220 \text { HBO B } \\
\text { International Busi- } \\
\text { ness and Langua- } \\
\text { ges }\end{array}$ & $\begin{array}{l}\text { Count } \\
\text { \% within Adm. } \\
\text { codenr.: oplei- } \\
\text { dingsrichting }\end{array}$ & $25,0 \%$ & $50,0 \%$ & $25,0 \%$ & $100,0 \%$ \\
\hline & $\begin{array}{l}71440230 \mathrm{HBO} \text { B } \\
\text { Small Business en } \\
\text { Retail Management }\end{array}$ & $\begin{array}{l}\text { Count } \\
\% \text { within Adm. } \\
\text { codenr.: oplei- } \\
\text { dingsrichting }\end{array}$ & $26,2 \%$ & $47,6 \%$ & $26,2 \%$ & $100,0 \%$ \\
\hline & $\begin{array}{l}71440240 \text { HBO B } \\
\text { Food \& Business }\end{array}$ & $\begin{array}{l}\text { Count } \\
\% \text { within Adm. } \\
\text { codenr.: oplei- } \\
\text { dingsrichting }\end{array}$ & $12,5 \%$ & $37,5 \%$ & $50,0 \%$ & 8 \\
\hline Total & & $\begin{array}{l}\text { Count } \\
\% \text { within Adm. } \\
\text { codenr.: oplei- } \\
\text { dingsrichting }\end{array}$ & 59 & 165 & 79 & 303 \\
\hline
\end{tabular}




\section{Beheersing marktonderzoek}

Uitvoeren, interpreteren, toetsen en evalueren van marktonderzoek

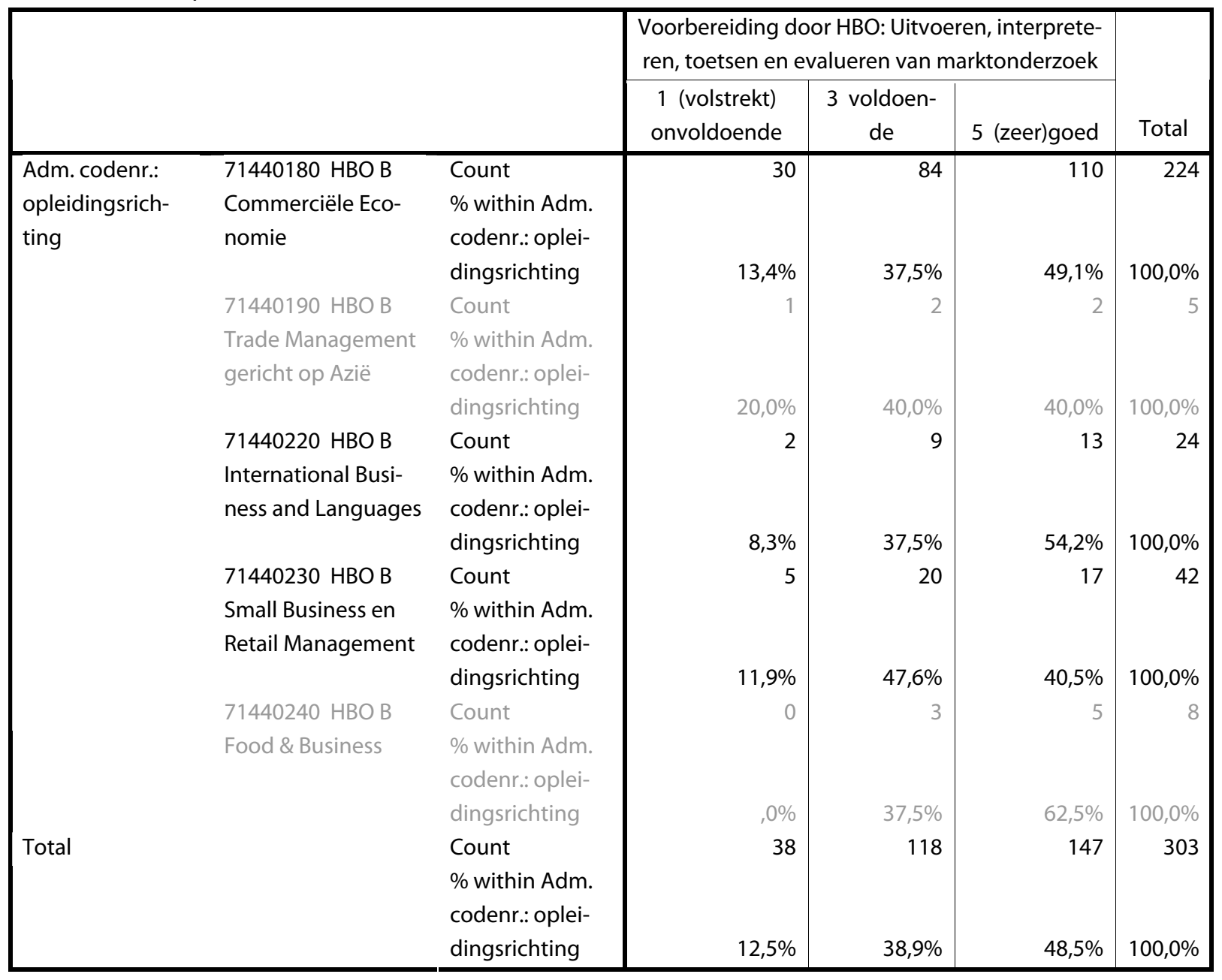




\section{Analyse interne en externe omgeving}

Vaststellen voor een onderneming van enerzijds de sterktes en zwaktes op basis van een analyse van de interne bedrijfsprocessen en -cultuur, als onderdeel van de waardeketen, en anderzijds van de kansen en bedreigingen op de lokale, nationale en/of internationale markt op basis van relevante nationale en internationale trends

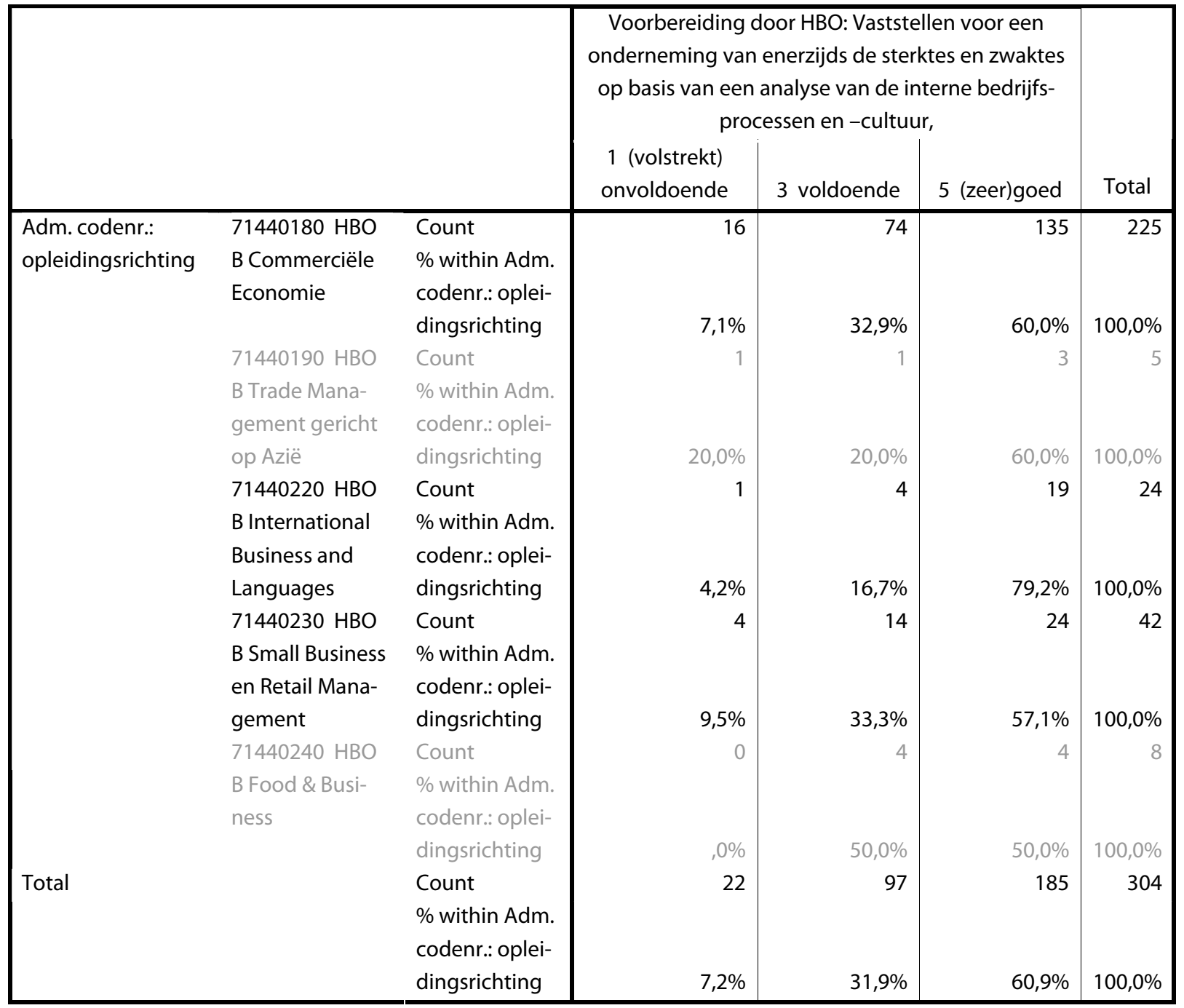




\section{Ontwikkelen marketingbeleid}

Ontwikkelen van marketingbeleid (ondernemingsbeleid) voor een nationaal of internationaal opererende onderneming en het kunnen onderbouwen en beargumenteren van gemaakte keuzes

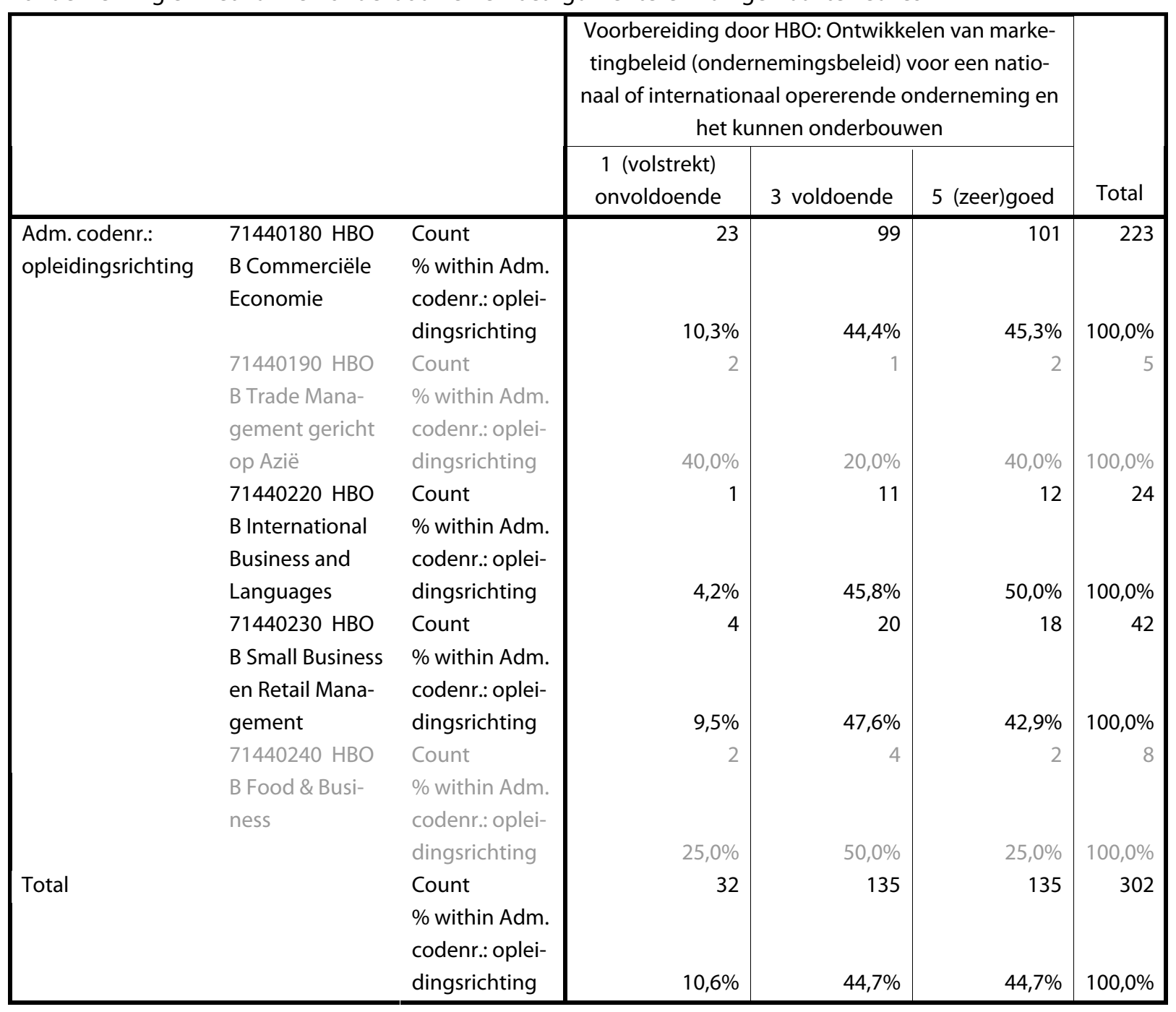




\section{Implementatie marketingbeleid}

Opstellen, uitvoeren en bijstellen van plannen vanuit het marketingbeleid (ondernemingsbeleid)

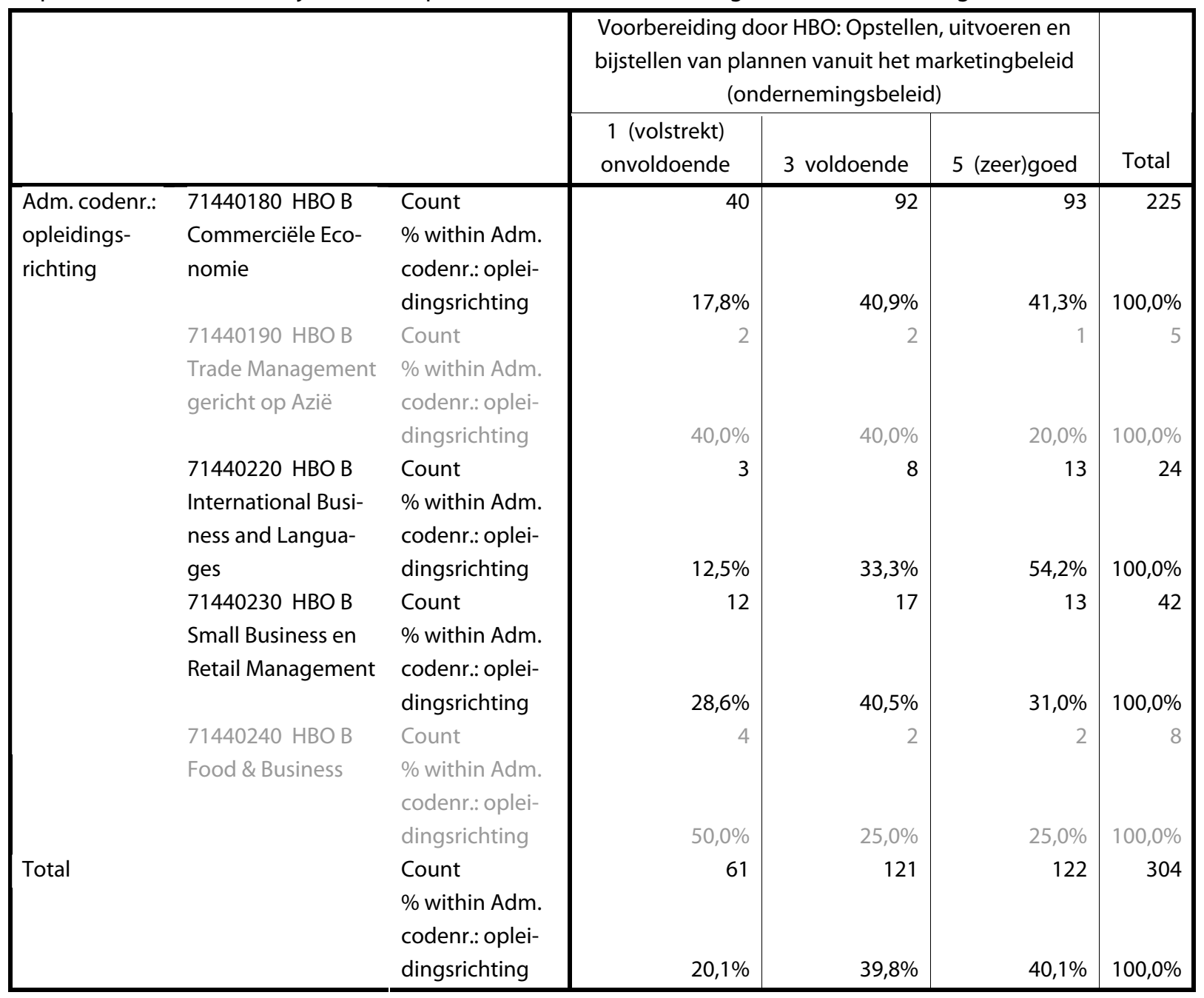




\section{Zakelijke relaties onderhouden}

Ontwikkelen en onderhouden van zakelijke relaties ten behoeve van inkoop, verkoop en dienstverlening

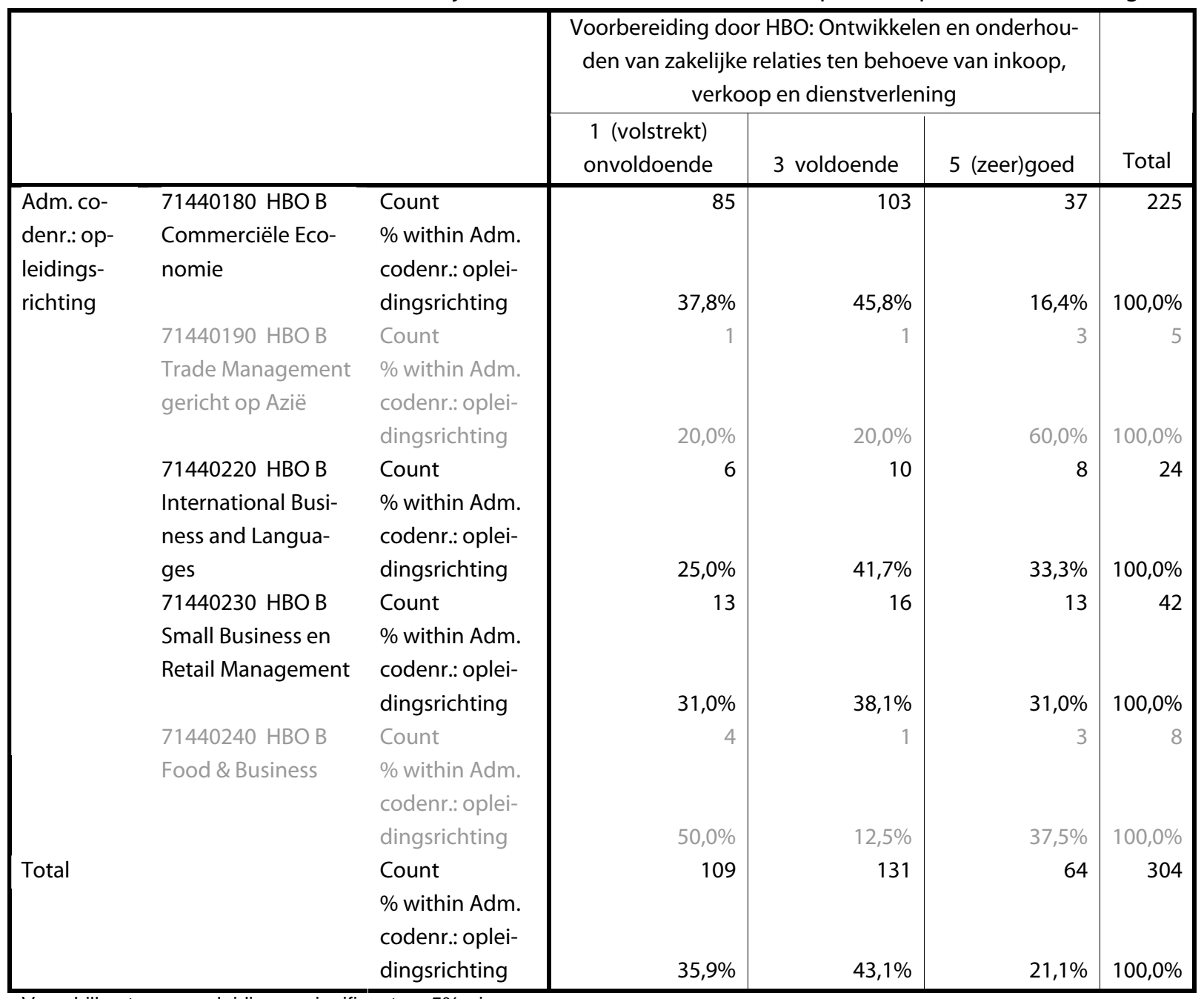

Verschillen tussen opleidingen significant op 5\%-niveau. 


\section{Communiceren in interculturele context}

Communiceren in meer talen en rekening houdend met culturele verschillen, intern en extern, nationaal en internationaal

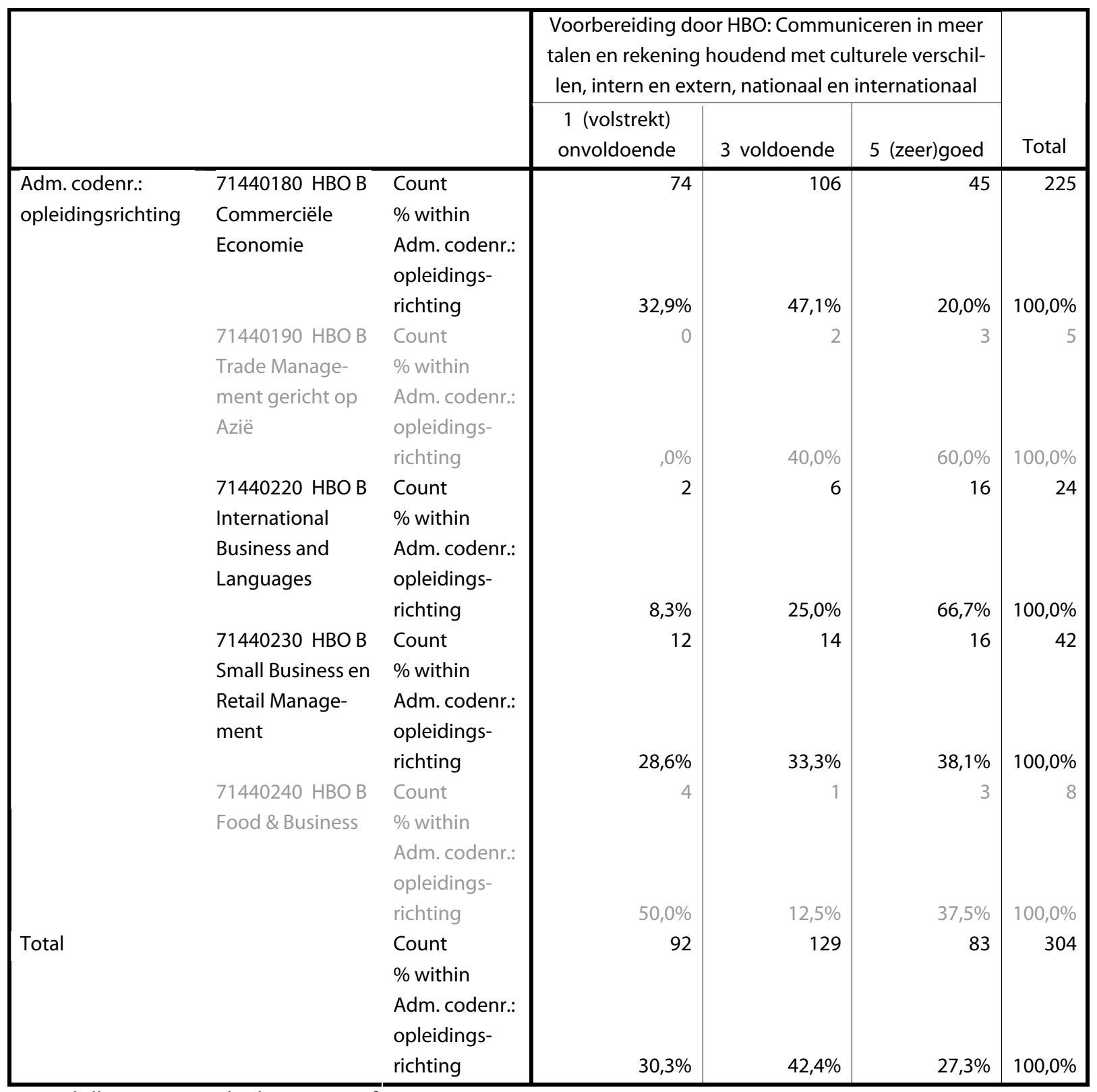

Verschillen tussen opleidingen significant op 1\%-niveau. 


\section{Leiding geven}

Leiding geven aan een bedrijf, een bedrijfsonderdeel, bedrijfsprocessen of een project

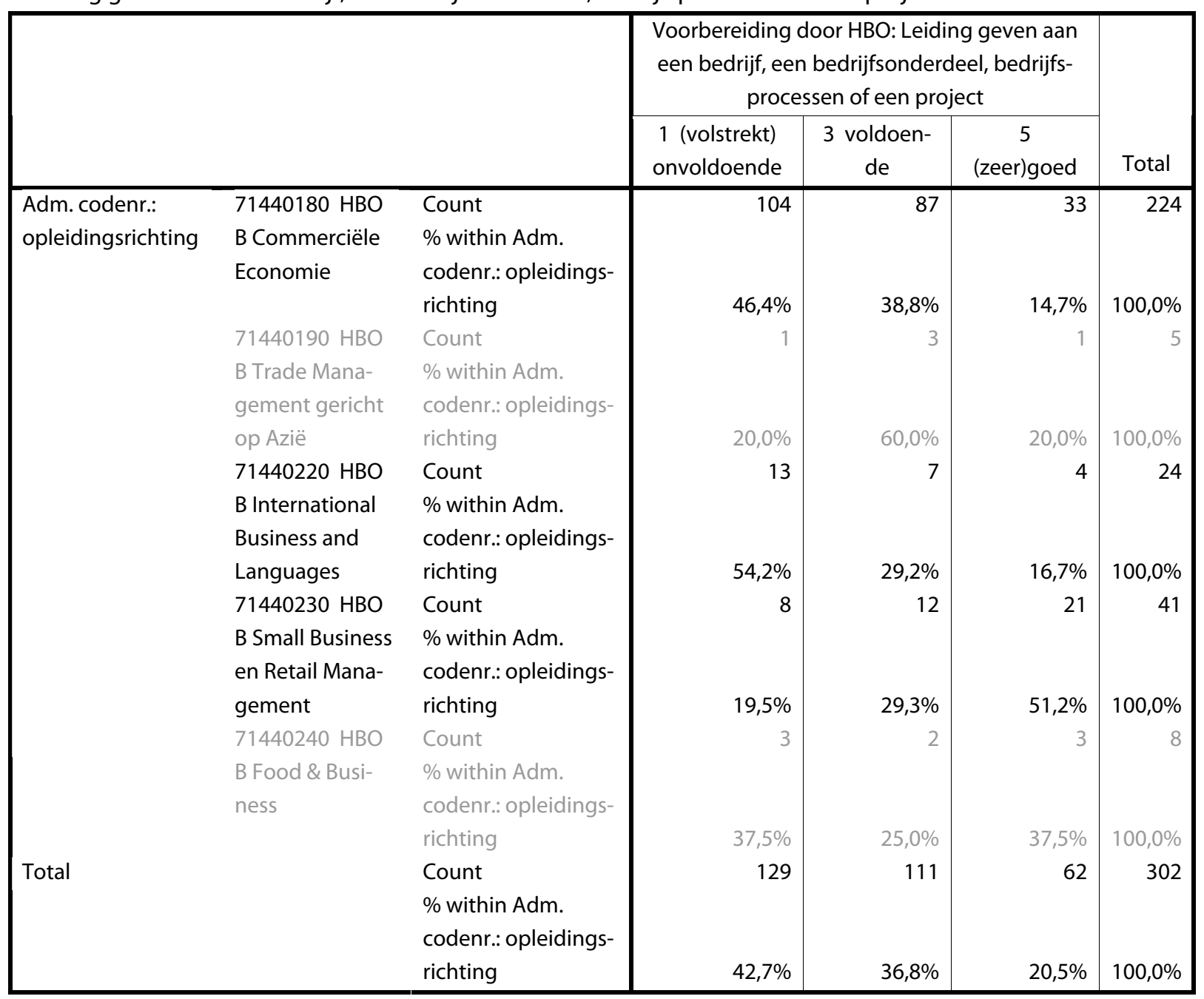

Verschillen tussen opleidingen significant op 1\%-niveau. 


\subsection{Business Administration}

Opleidingen in de steekproef

\begin{tabular}{|c|c|c|c|c|c|}
\hline & & Frequency & Percent & Valid Percent & $\begin{array}{l}\text { Cumulative } \\
\text { Percent }\end{array}$ \\
\hline Valid & $\begin{array}{l}71241000 \text { HBO Ad Functiegerichte BA in } \\
\text { toerisme en recreatie } \\
71440150 \text { HBO B Bestuurskun- } \\
\text { de/Overheidsmanagement } \\
71440160 \text { HBO B Management, Economie } \\
\text { en Recht } \\
71440200 \text { HBO B Logistiek en Economie } \\
71440350 \text { HBO B Facility Management } \\
71440360 \text { HBO B Hoger Hotelonderwijs } \\
71440370 \text { HBO B Hoger Toeristisch en Re- } \\
\text { creatief Onderwijs } \\
71440380 \text { HBO B Vrijetijdsmanagement } \\
71440510 \text { HBO B Hoger Toeristisch Mana- } \\
\text { gement } \\
71440560 \text { HBO B Office management } \\
71441090 \text { HBO B International Business and } \\
\text { Management Studies } \\
71441110 \text { HBO B Media en Entertainment } \\
\text { Management } \\
71441140 \text { HBO B Integrale Veiligheid } \\
71441150 \text { HBO B Vastgoed en Makelaardij } \\
71441250 \text { HBO B Bouwmanagement en } \\
\text { Vastgoed } \\
71441310 \text { HBO B Integrale Veiligheidskun- } \\
\text { de } \\
71540100 \text { HBO M International Hospitality } \\
\text { Management } \\
\text { Total }\end{array}$ & $\begin{array}{r}19 \\
246 \\
41 \\
75 \\
89 \\
\\
68 \\
99 \\
7 \\
1\end{array}$ & $\begin{array}{r}2,6 \\
33,2 \\
5,5 \\
10,1 \\
12,0 \\
9,2 \\
13,4 \\
\\
, 9 \\
, 1\end{array}$ & $\begin{array}{r}3,5 \\
3,8 \\
, 8 \\
3,6 \\
, 3 \\
, 5 \\
, 1 \\
100,0\end{array}$ & $\begin{array}{l}90,8 \\
94,6 \\
95,4 \\
99,1 \\
99,3 \\
99,9\end{array}$ \\
\hline
\end{tabular}




\subsubsection{Vereist niveau (Business Administration)}

\section{Analyse externe omgeving}

Ontwikkelen van een visie op veranderingen en trends in de externe omgeving en ontwikkelen van relaties, netwerken en ketens

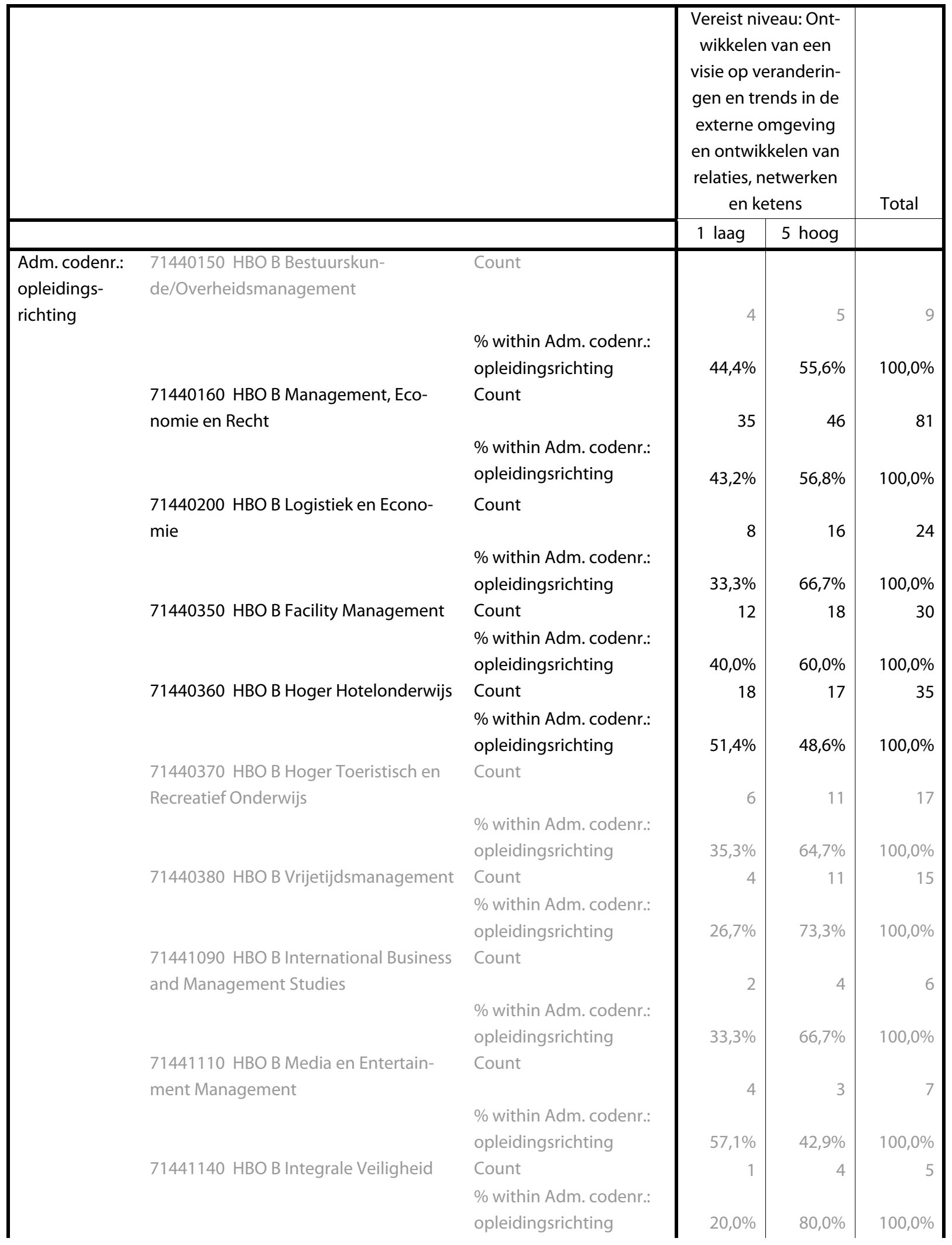




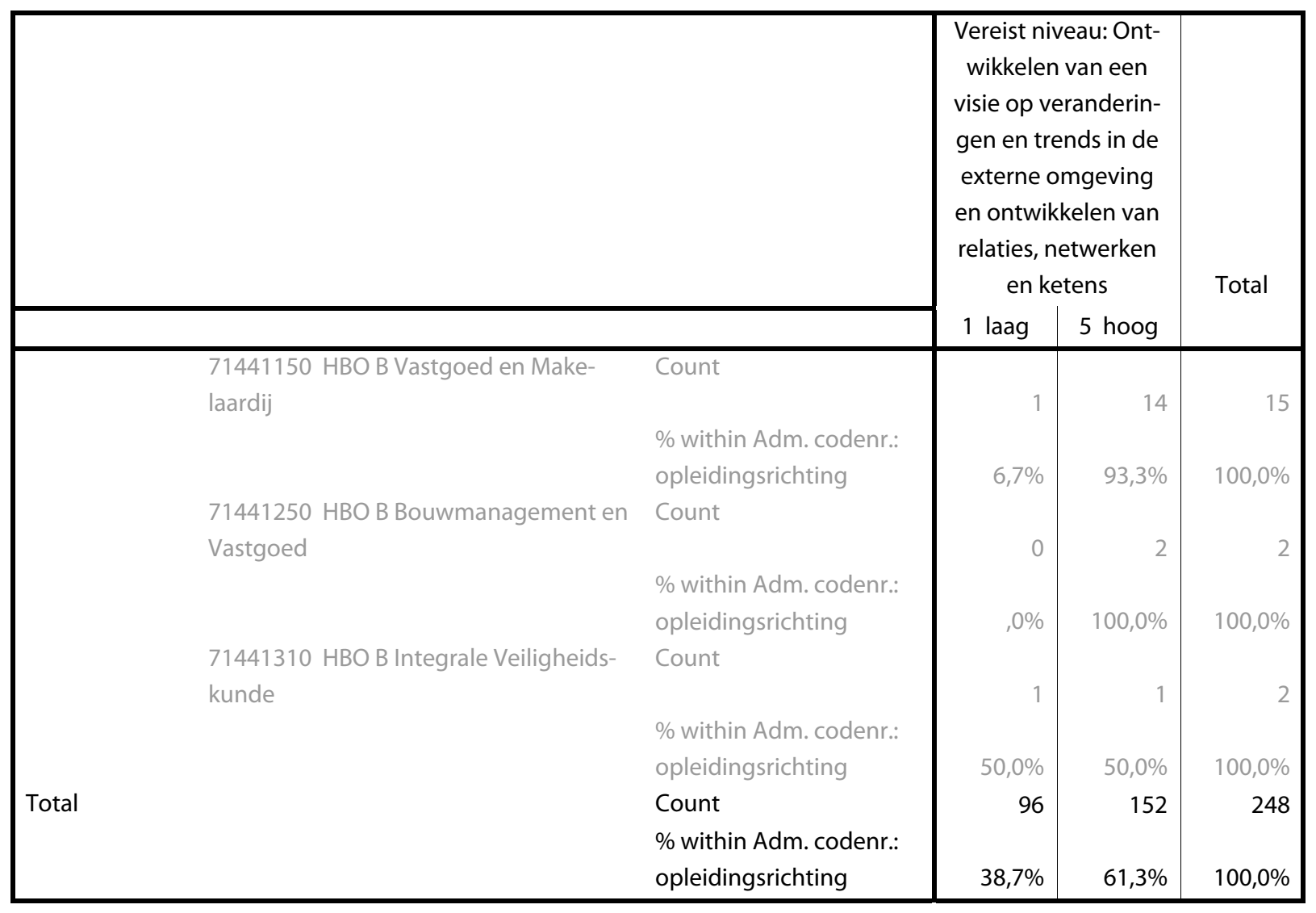




\section{Beleidsontwikkeling}

Analyseren van beleidsvraagstukken, vertalen in beleidsdoelstellingen en -alternatieven en voorbereiden van besluitvorming

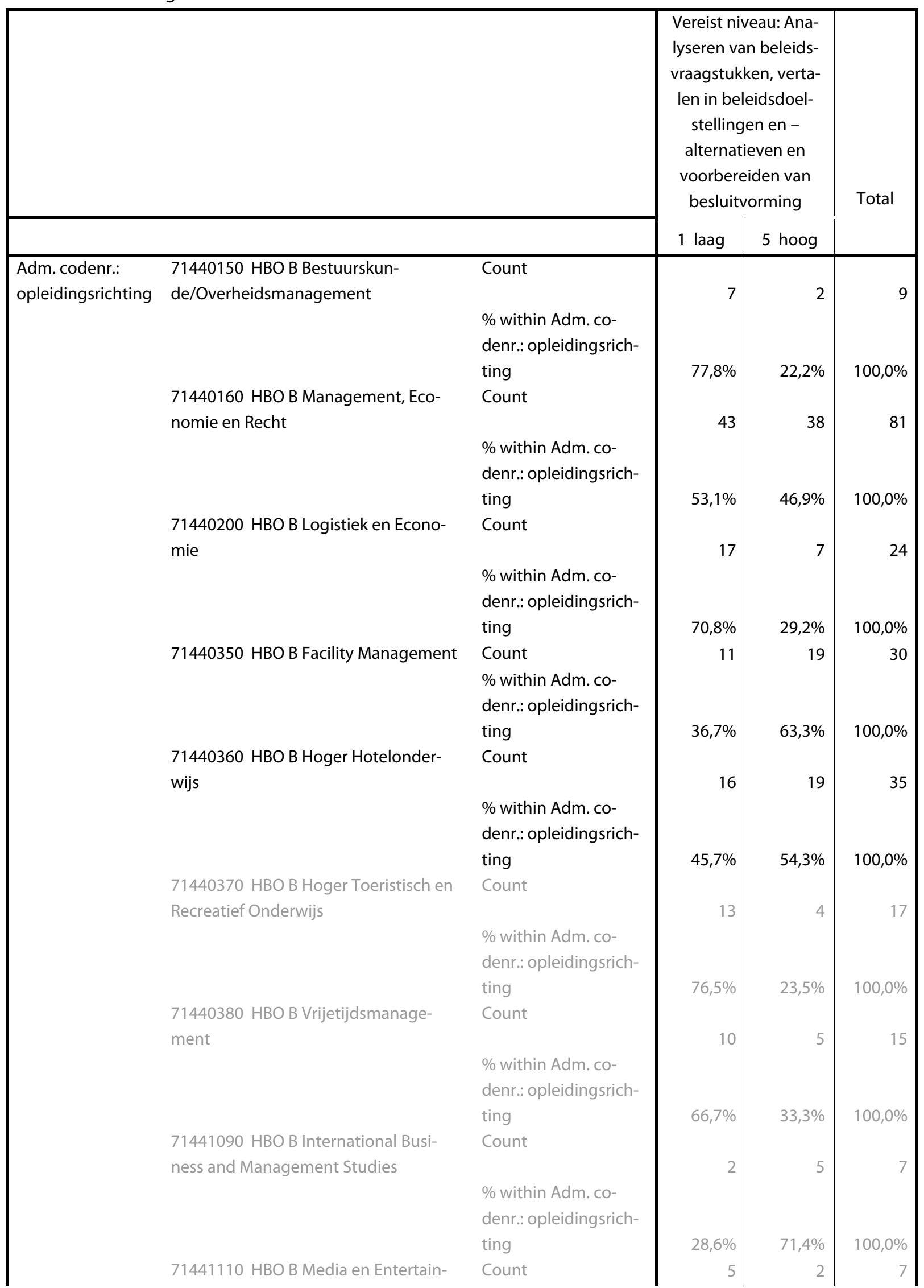




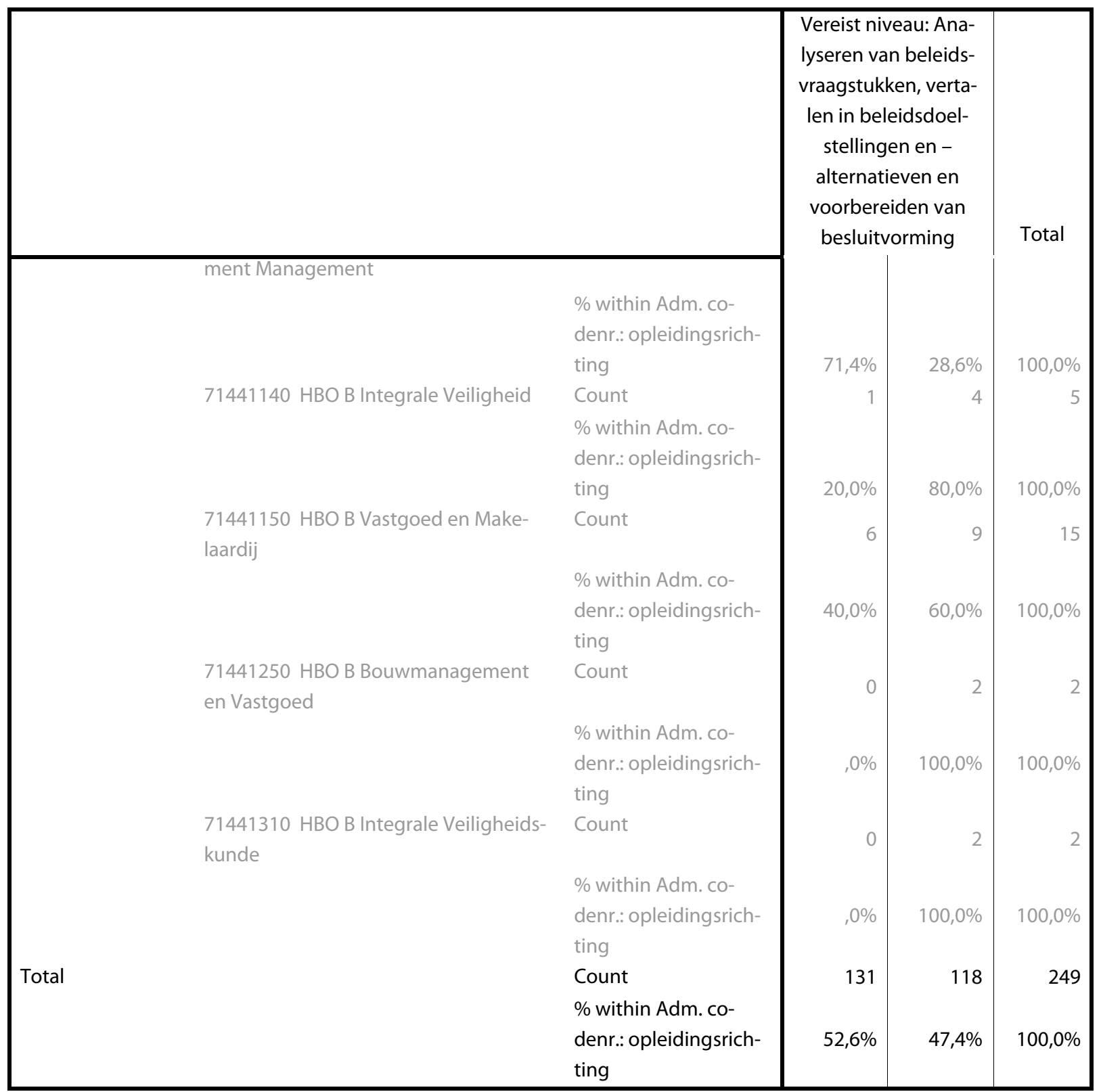

Verschillen tussen opleidingen significant op 5\%-niveau. 
Toepassen van human resource management in het licht van de strategie van de organisatie

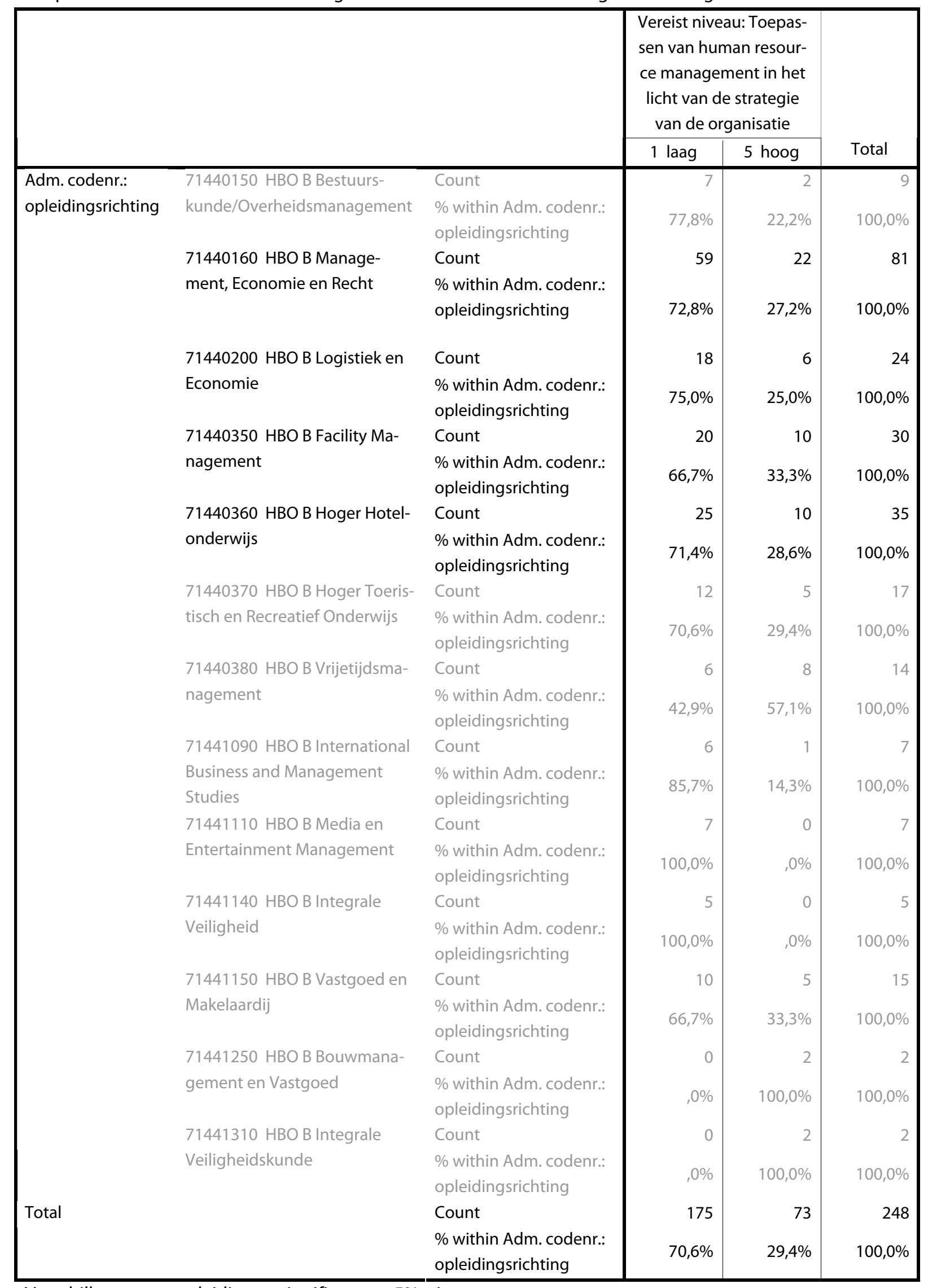

Verschillen tussen opleidingen significant op 5\%-niveau. 


\section{Procesmanagement}

Inrichten, beheersen en verbeteren van bedrijfs- of organisatieprocessen

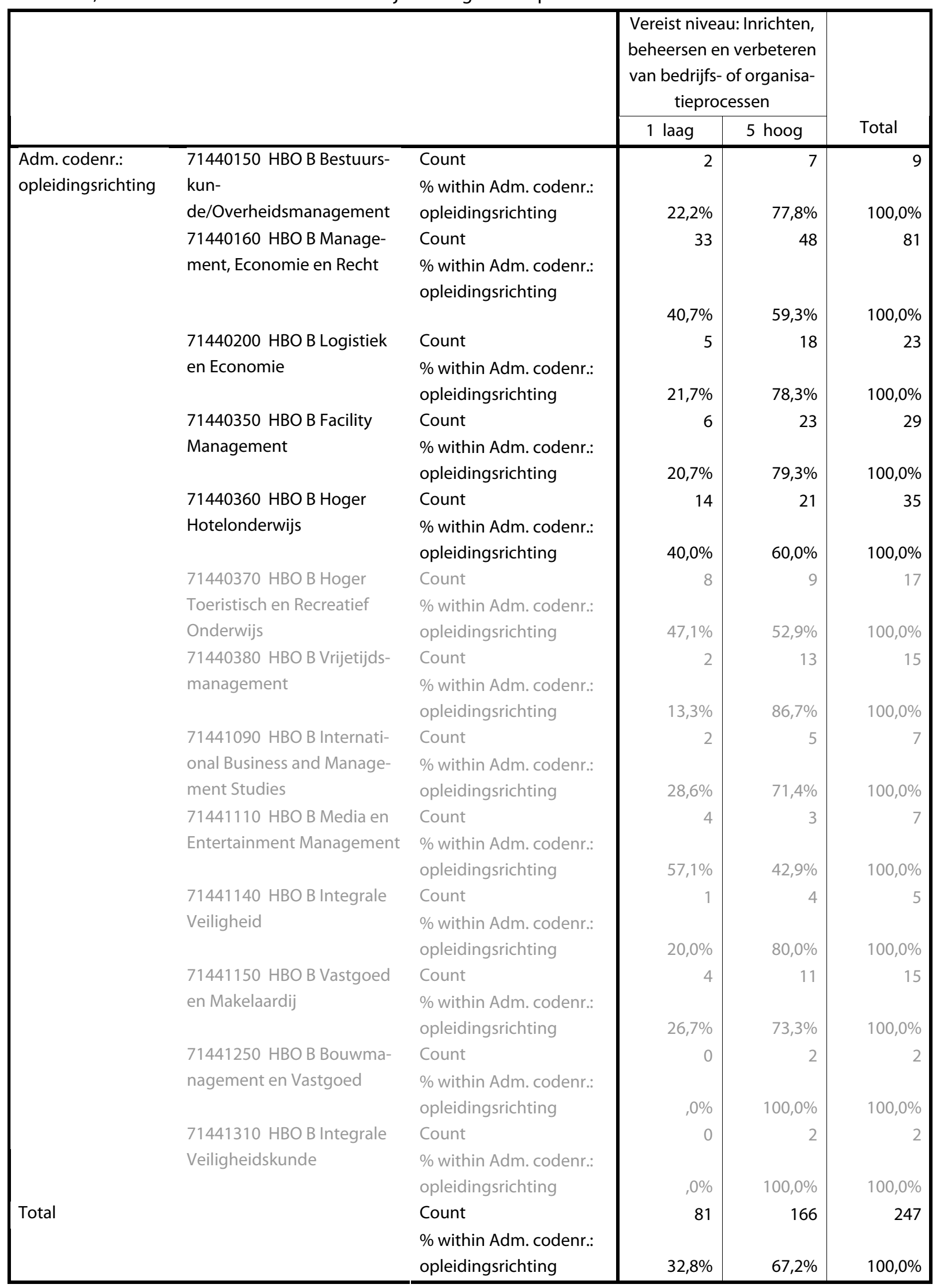




\section{Analyseren financiële en juridische aspecten en interne omgeving}

Analyseren van de financiële en juridische aspecten, interne processen en de bedrijfs- of organisatieomgeving om samenhang en wisselwerking te versterken

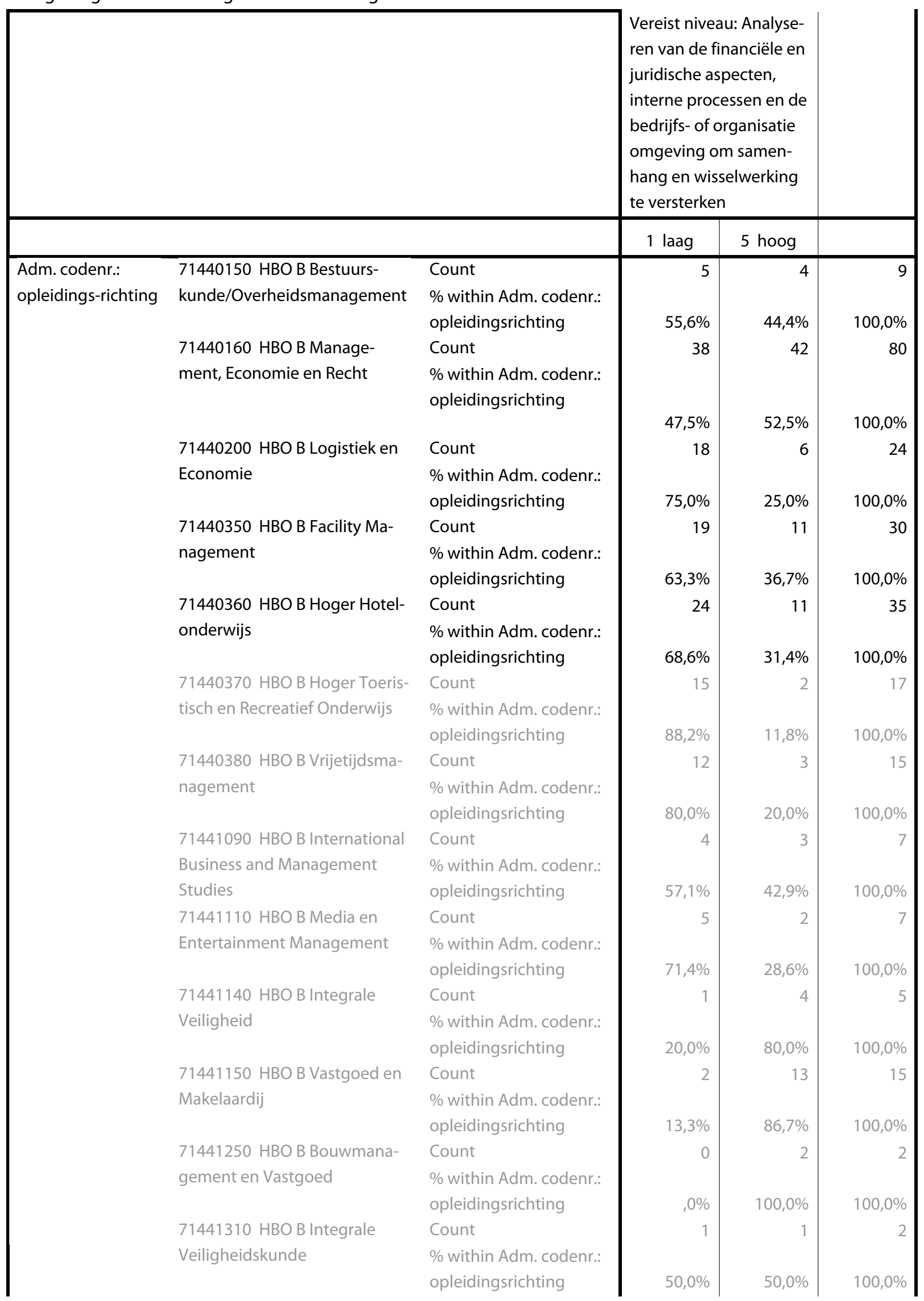




\begin{tabular}{|c|c|c|c|c|}
\hline & & \multicolumn{2}{|c|}{$\begin{array}{l}\text { Vereist niveau: Analyse- } \\
\text { ren van de financiële en } \\
\text { juridische aspecten, } \\
\text { interne processen en de } \\
\text { bedrijfs- of organisatie } \\
\text { omgeving om samen- } \\
\text { hang en wisselwerking } \\
\text { te versterken }\end{array}$} & \\
\hline \multirow[b]{2}{*}{ Total } & & 1 laag & 5 hoog & \\
\hline & $\begin{array}{l}\text { Count } \\
\% \text { within Adm. codenr.: } \\
\text { opleidingsrichting }\end{array}$ & $\begin{array}{r}144 \\
58,1 \%\end{array}$ & $\begin{array}{r}104 \\
41,9 \%\end{array}$ & $\begin{array}{r}248 \\
100,0 \%\end{array}$ \\
\hline
\end{tabular}

Verschillen tussen opleidingen significant op 5\%-niveau. 


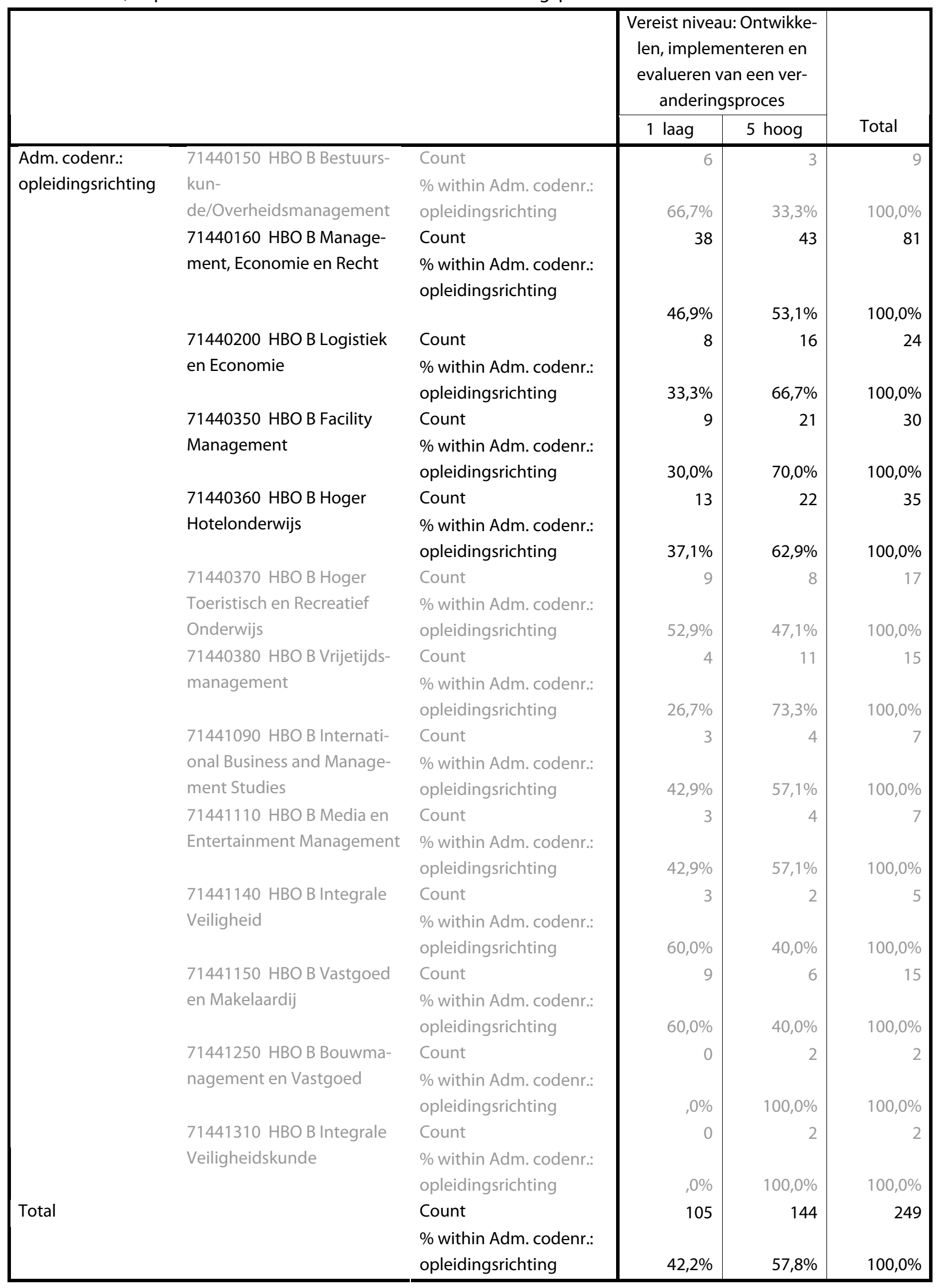




\subsubsection{Voorbereiding door hbo (Business Administration)}

\section{Analyse externe omgeving}

Ontwikkelen van een visie op veranderingen en trends in de externe omgeving en ontwikkelen van relaties, netwerken en ketens

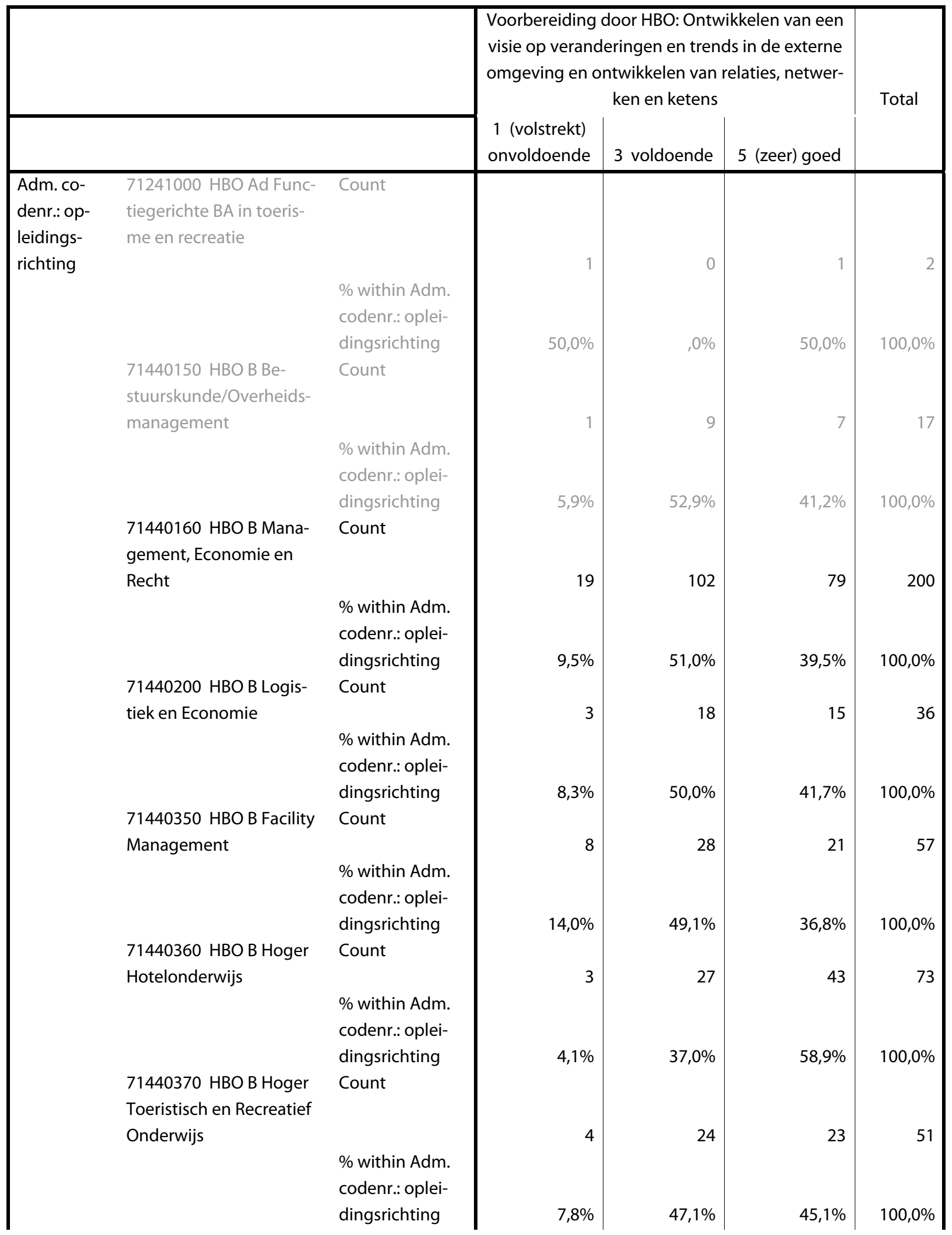




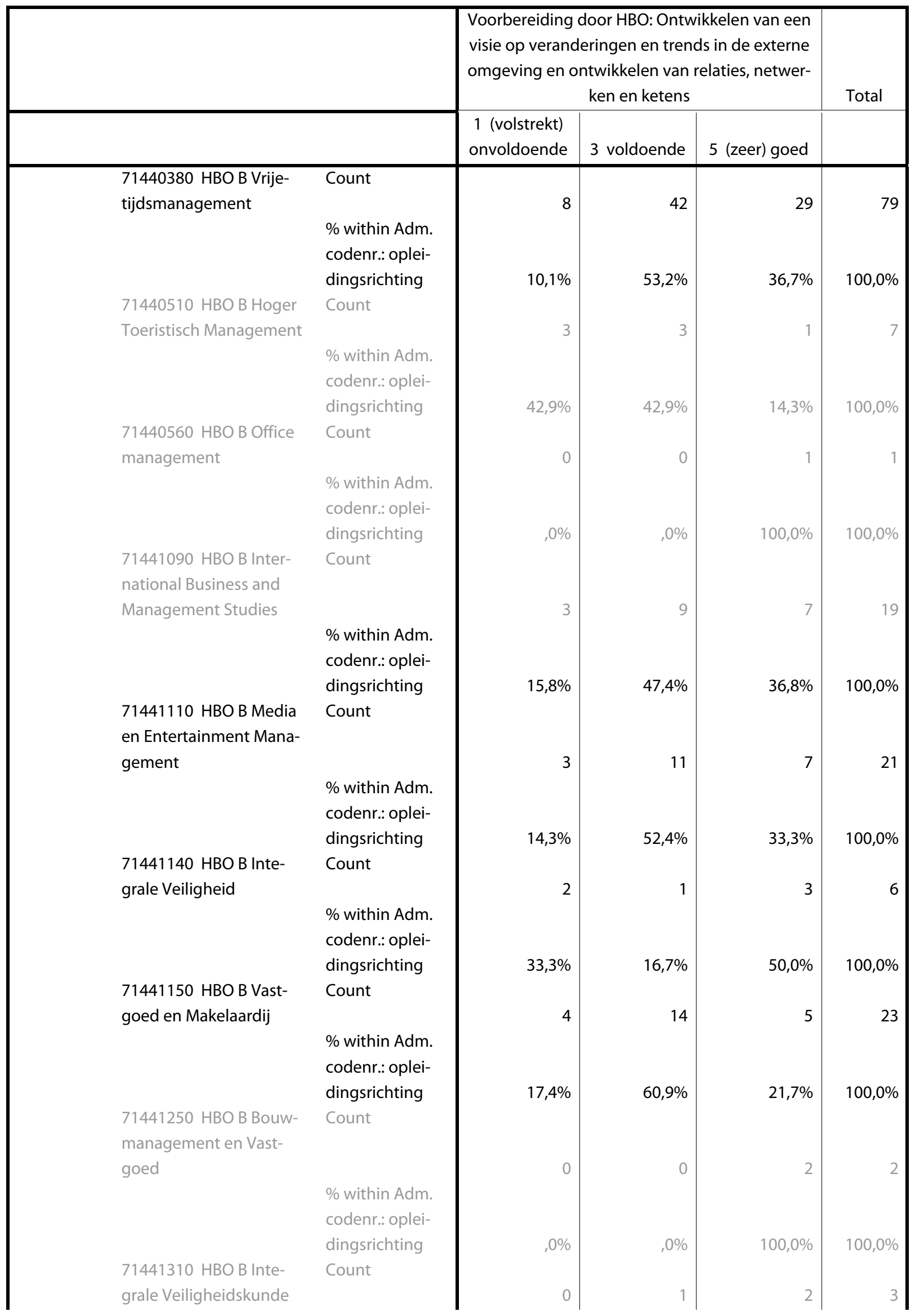




\begin{tabular}{|c|c|c|c|c|c|}
\hline & & \multicolumn{3}{|c|}{$\begin{array}{l}\text { Voorbereiding door HBO: Ontwikkelen van een } \\
\text { visie op veranderingen en trends in de externe } \\
\text { omgeving en ontwikkelen van relaties, netwer- } \\
\text { ken en ketens }\end{array}$} & \multirow[t]{2}{*}{ Total } \\
\hline & & $\begin{array}{c}1 \text { (volstrekt) } \\
\text { onvoldoende }\end{array}$ & 3 voldoende & 5 (zeer) goed & \\
\hline Total & $\begin{array}{l}\text { \% within Adm. } \\
\text { codenr.: oplei- } \\
\text { dingsrichting } \\
\text { Count } \\
\text { \% within Adm. } \\
\text { codenr.: oplei- } \\
\text { dingsrichting }\end{array}$ & $\begin{array}{r}, 0 \% \\
62 \\
\\
10,4 \%\end{array}$ & $\begin{array}{r}33,3 \% \\
289 \\
48,4 \%\end{array}$ & $\begin{array}{r}66,7 \% \\
246 \\
41,2 \%\end{array}$ & $\begin{array}{r}100,0 \% \\
597 \\
100,0 \%\end{array}$ \\
\hline
\end{tabular}




\section{Beleidsontwikkeling}

Analyseren van beleidsvraagstukken, vertalen in beleidsdoelstellingen en -alternatieven en voorbereiden van besluitvorming

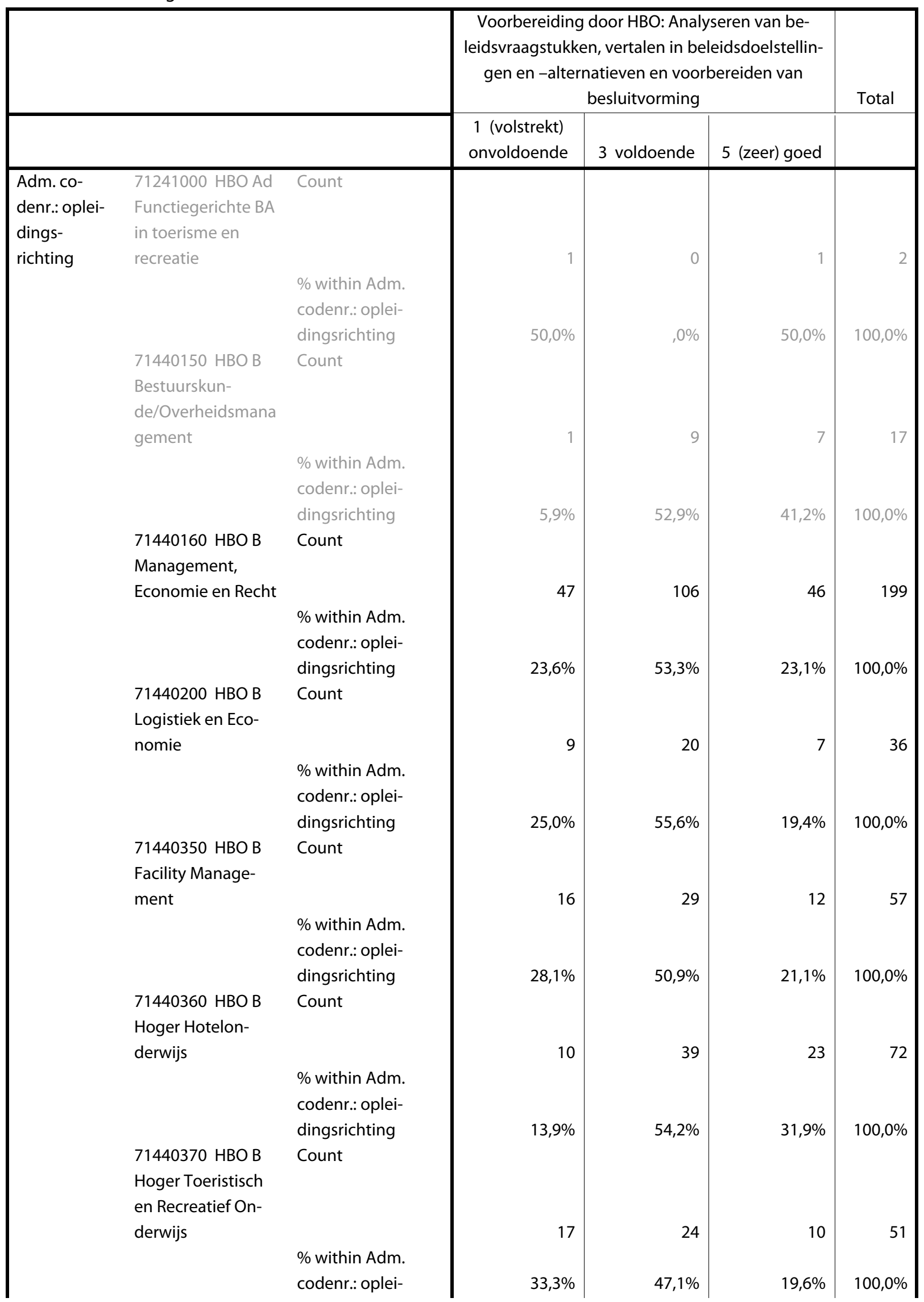




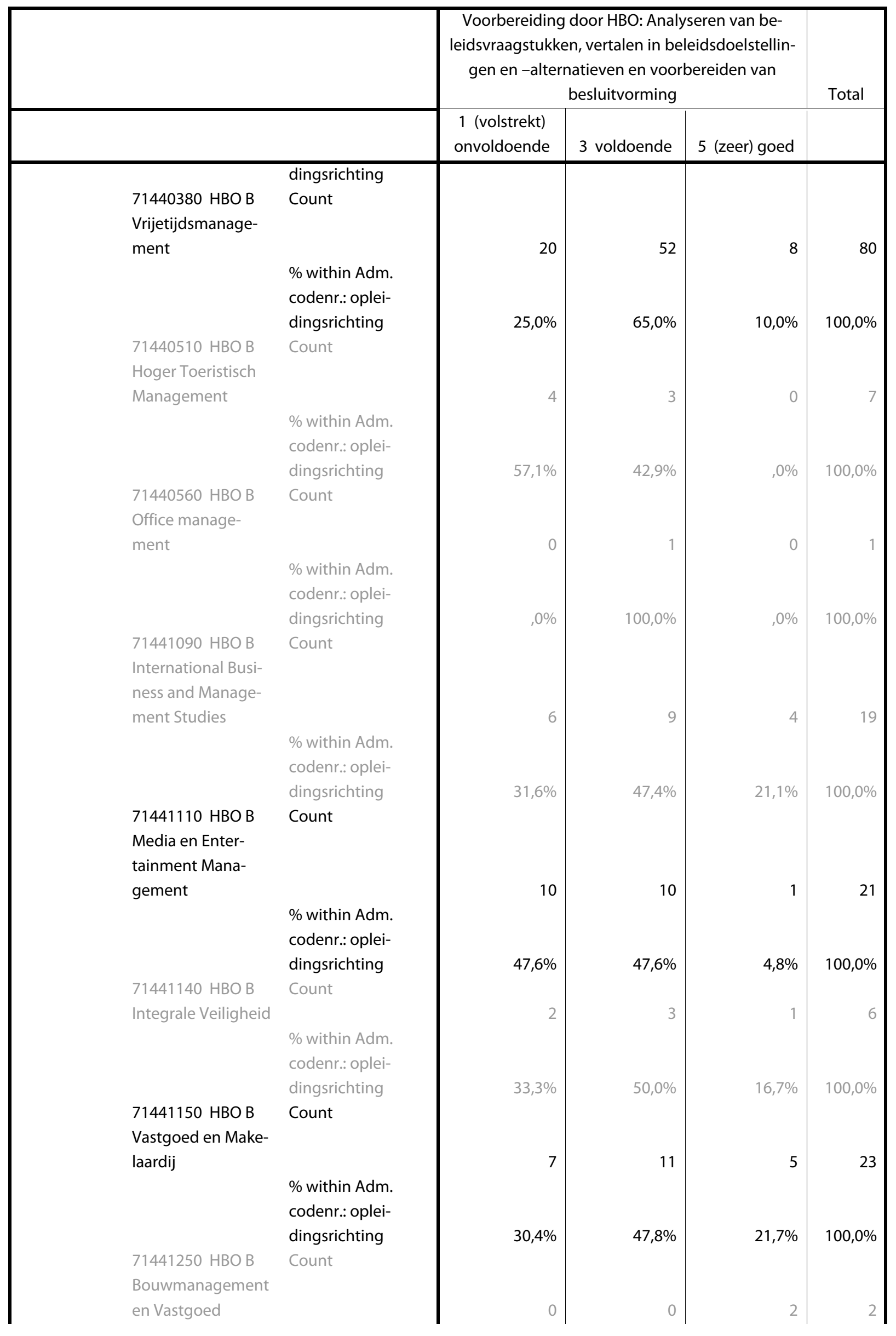




\begin{tabular}{|c|c|c|c|c|c|c|}
\hline & & & $\begin{array}{l}\text { Voorbereiding } \\
\text { leidsvraagstukke } \\
\text { gen en -alterr }\end{array}$ & $\begin{array}{l}\text { door HBO: Analy } \\
\text { n, vertalen in be } \\
\text { atieven en voor } \\
\text { besluitvorming }\end{array}$ & $\begin{array}{l}\text { eren van be- } \\
\text { eidsdoelstellin- } \\
\text { ereiden van }\end{array}$ & Total \\
\hline & & & $\begin{array}{c}1 \text { (volstrekt) } \\
\text { onvoldoende }\end{array}$ & 3 voldoende & 5 (zeer) goed & \\
\hline Total & $\begin{array}{l}71441310 \text { HBO B } \\
\text { Integrale Veilig- } \\
\text { heidskunde }\end{array}$ & $\begin{array}{l}\text { \% within Adm. } \\
\text { codenr.: oplei- } \\
\text { dingsrichting } \\
\text { Count } \\
\text { \% within Adm. } \\
\text { codenr.: oplei- } \\
\text { dingsrichting } \\
\text { Count } \\
\text { \% within Adm. } \\
\text { codenr.: oplei- } \\
\text { dingsrichting }\end{array}$ & $\begin{array}{r} \\
\\
\\
\\
0 \\
\\
\\
\\
, 0 \% \\
150 \\
\\
25,2 \%\end{array}$ & $\begin{array}{r}, 0 \% \\
0 \\
\\
\\
, 0 \% \\
316 \\
\\
53,0 \%\end{array}$ & $\begin{array}{r}100,0 \% \\
3 \\
100,0 \% \\
130 \\
21,8 \%\end{array}$ & $\begin{array}{r}100,0 \% \\
3 \\
100,0 \% \\
596 \\
100,0 \%\end{array}$ \\
\hline
\end{tabular}

Verschillen tussen opleidingen significant op 1\%-niveau. 


\section{Human resource management}

Toepassen van human resource management in het licht van de strategie van de organisatie

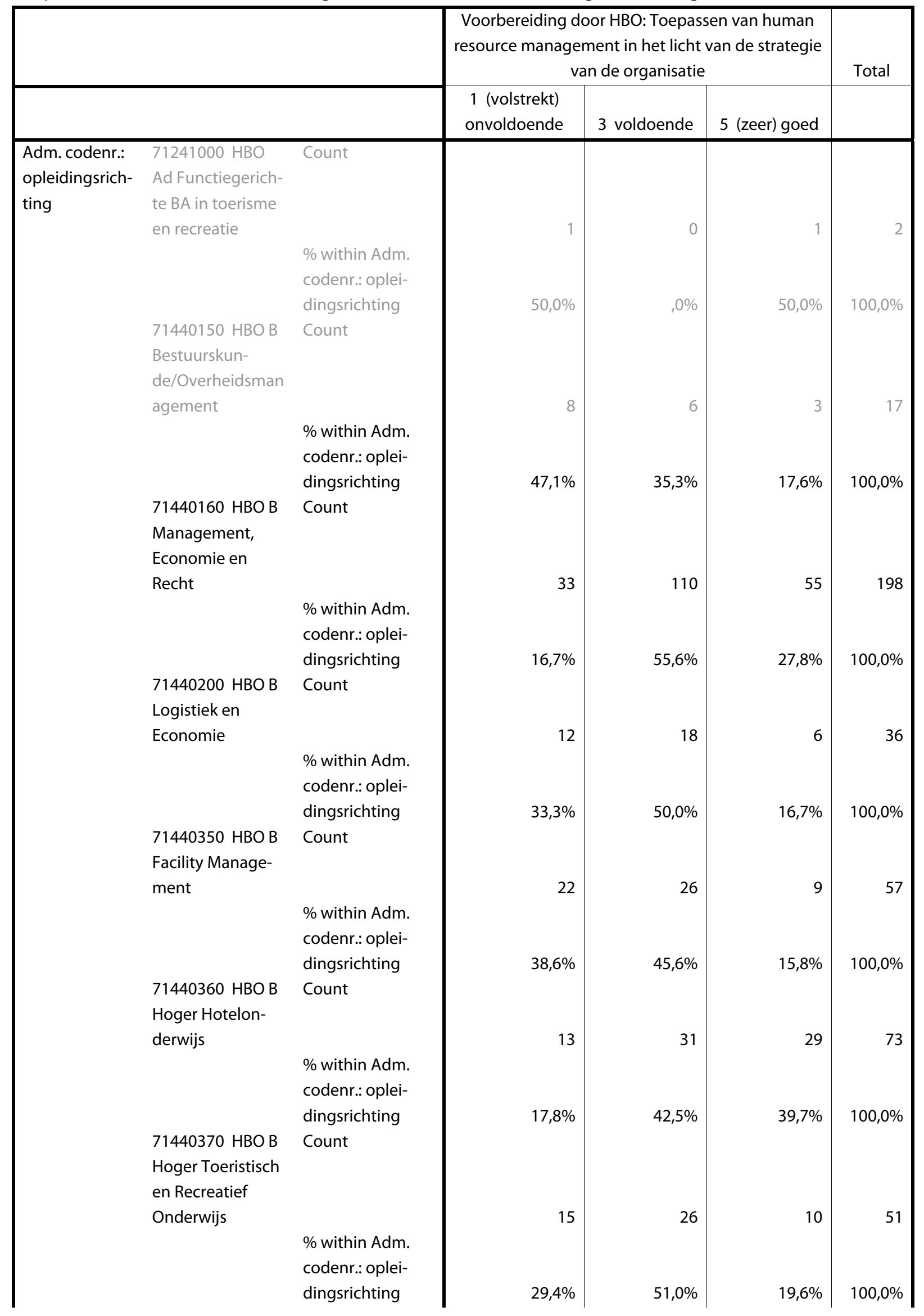




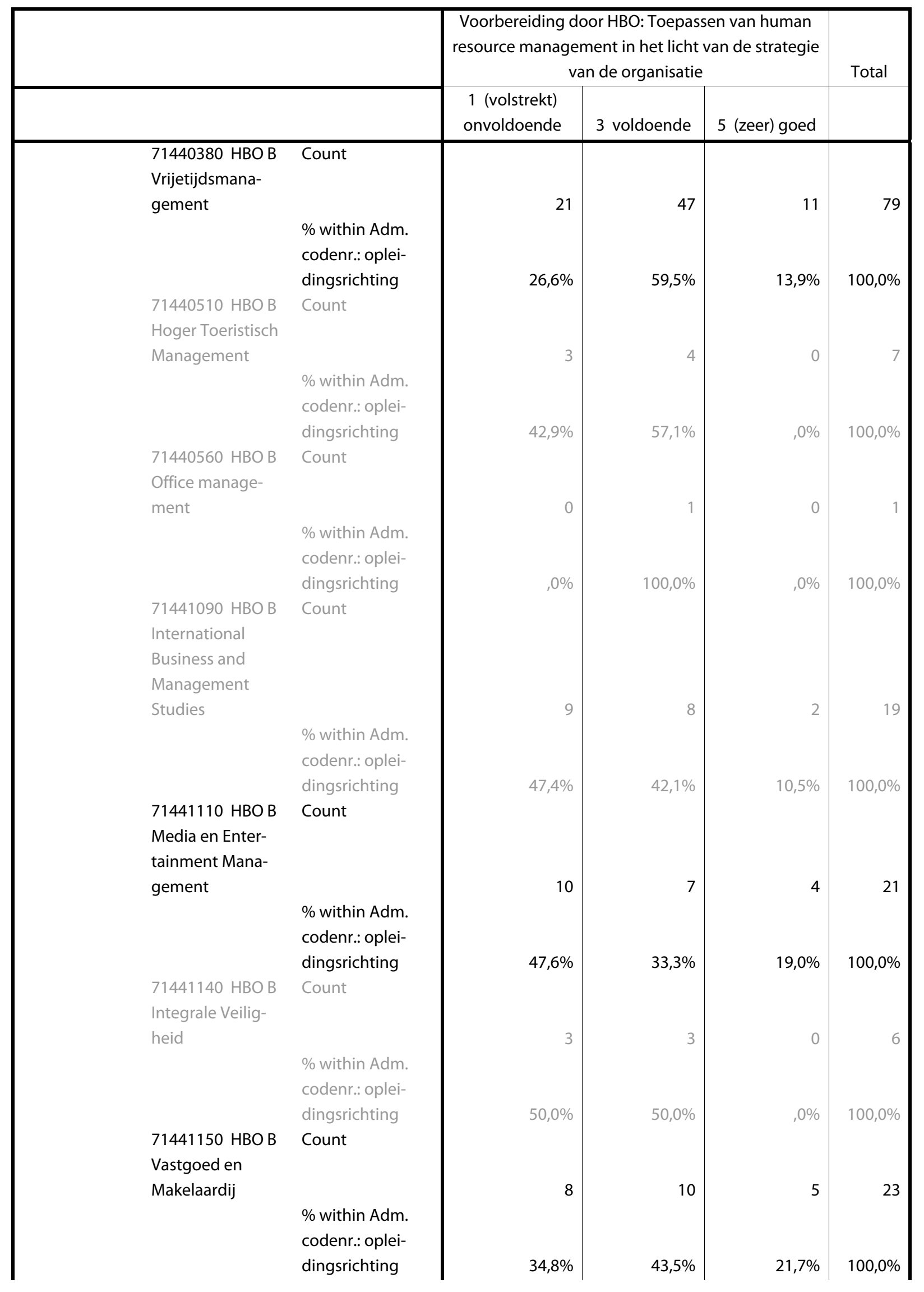




\begin{tabular}{|c|c|c|c|c|c|c|}
\hline & & & \multicolumn{3}{|c|}{$\begin{array}{l}\text { Voorbereiding door HBO: Toepassen van human } \\
\text { resource management in het licht van de strategie } \\
\text { van de organisatie }\end{array}$} & \multirow[t]{2}{*}{ Total } \\
\hline & & & $\begin{array}{l}1 \text { (volstrekt) } \\
\text { onvoldoende }\end{array}$ & 3 voldoende & 5 (zeer) goed & \\
\hline Total & $\begin{array}{l}71441250 \text { HBO B } \\
\text { Bouwmanage- } \\
\text { ment en Vast- } \\
\text { goed } \\
71441310 \text { HBO B } \\
\text { Integrale Veilig- } \\
\text { heidskunde }\end{array}$ & $\begin{array}{l}\text { Count } \\
\text { \% within Adm. } \\
\text { codenr.: oplei- } \\
\text { dingsrichting } \\
\text { Count } \\
\text { \% within Adm. } \\
\text { codenr.: oplei- } \\
\text { dingsrichting } \\
\text { Count } \\
\text { \% within Adm. } \\
\text { codenr.: oplei- } \\
\text { dingsrichting }\end{array}$ & $\begin{array}{r}0 \\
\\
\\
\\
1 \\
1 \\
\\
\\
33,3 \% \\
159 \\
26,7 \%\end{array}$ & $\begin{array}{r}0 \\
\\
\\
\\
0 \\
\\
\\
\\
, 0 \% \\
297 \\
\\
49,9 \%\end{array}$ & $\begin{array}{r}100,0 \% \\
2 \\
\\
\\
66,7 \% \\
139 \\
\\
23,4 \%\end{array}$ & $\begin{array}{r}2 \\
100,0 \% \\
3 \\
\\
100,0 \% \\
595 \\
100,0 \%\end{array}$ \\
\hline
\end{tabular}

Verschillen tussen opleidingen significant op 1\%-niveau. 


\section{Procesmanagement}

Inrichten, beheersen en verbeteren van bedrijfs- of organisatieprocessen

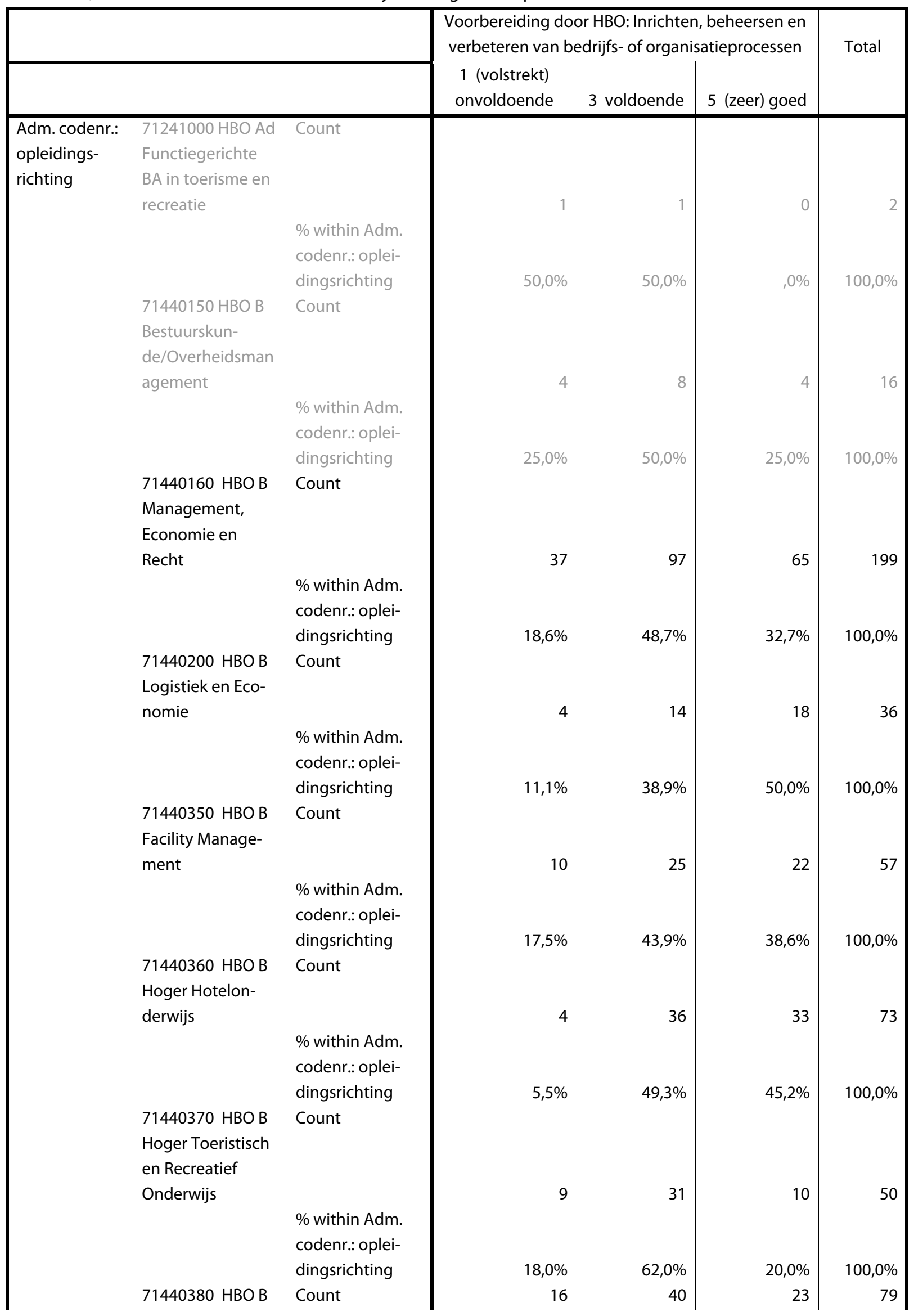




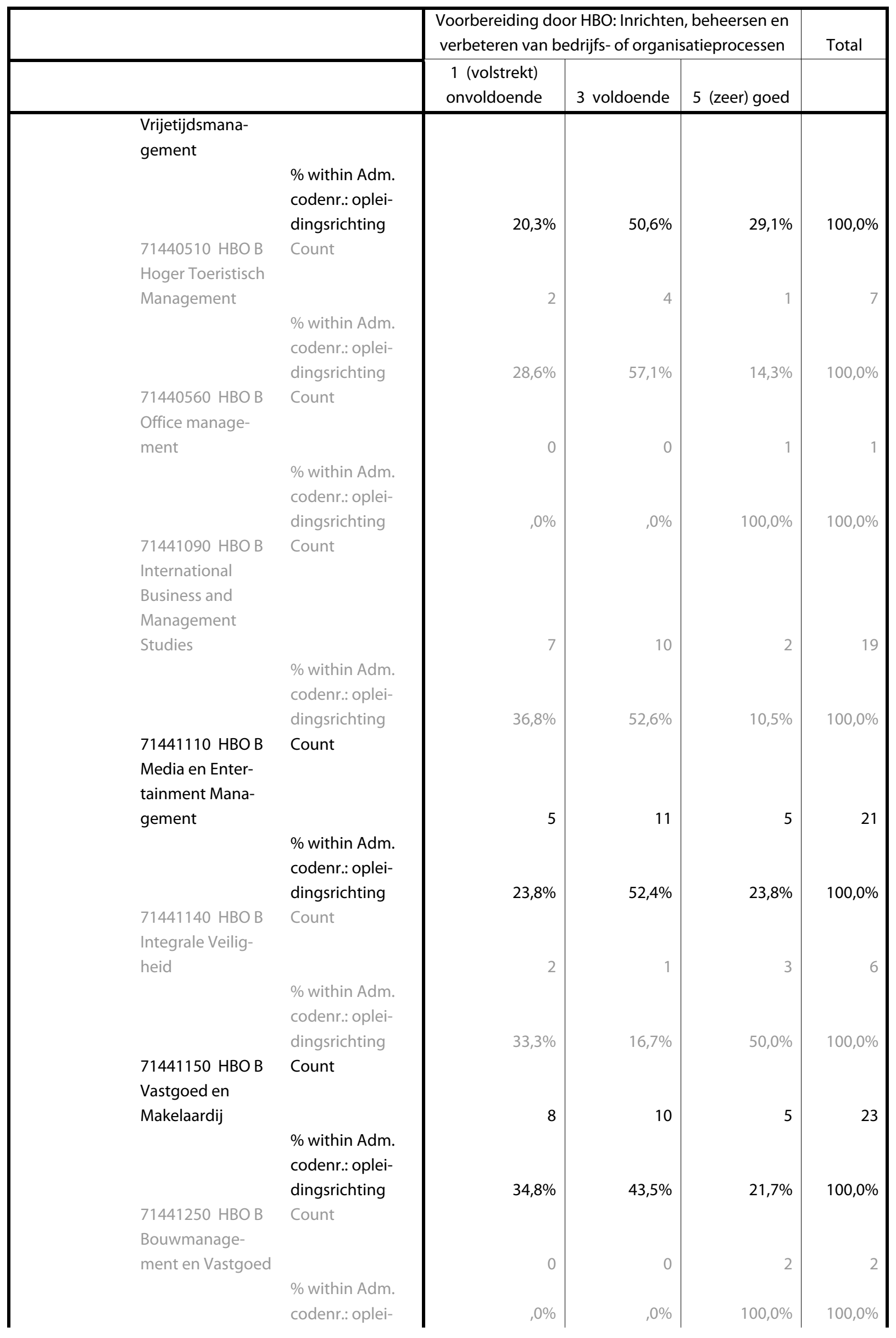




\begin{tabular}{|c|c|c|c|c|c|c|}
\hline & & & \multicolumn{3}{|c|}{$\begin{array}{l}\text { Voorbereiding door HBO: Inrichten, beheersen en } \\
\text { verbeteren van bedrijfs- of organisatieprocessen }\end{array}$} & \multirow[t]{2}{*}{ Total } \\
\hline & & & $\begin{array}{l}1 \text { (volstrekt) } \\
\text { onvoldoende }\end{array}$ & 3 voldoende & 5 (zeer) goed & \\
\hline Total & $\begin{array}{l}71441310 \text { HBO B } \\
\text { Integrale Veilig- } \\
\text { heidskunde }\end{array}$ & $\begin{array}{l}\text { dingsrichting } \\
\text { Count } \\
\text { \% within Adm. } \\
\text { codenr.: oplei- } \\
\text { dingsrichting } \\
\text { Count } \\
\text { \% within Adm. } \\
\text { codenr.: oplei- } \\
\text { dingsrichting }\end{array}$ & $\begin{array}{r}1 \\
33,3 \% \\
110 \\
18,5 \%\end{array}$ & $\begin{array}{r}33,3 \% \\
289 \\
48,7 \%\end{array}$ & $\begin{array}{r}33,3 \% \\
195 \\
32,8 \%\end{array}$ & $\begin{array}{r}100,0 \% \\
594 \\
100,0 \%\end{array}$ \\
\hline
\end{tabular}

Verschillen tussen opleidingen significant op 5\%-niveau. 


\section{Analyseren financiële en juridische aspecten en interne omgeving}

Analyseren van de financiële en juridische aspecten, interne processen en de bedrijfs- of organisatieomgeving

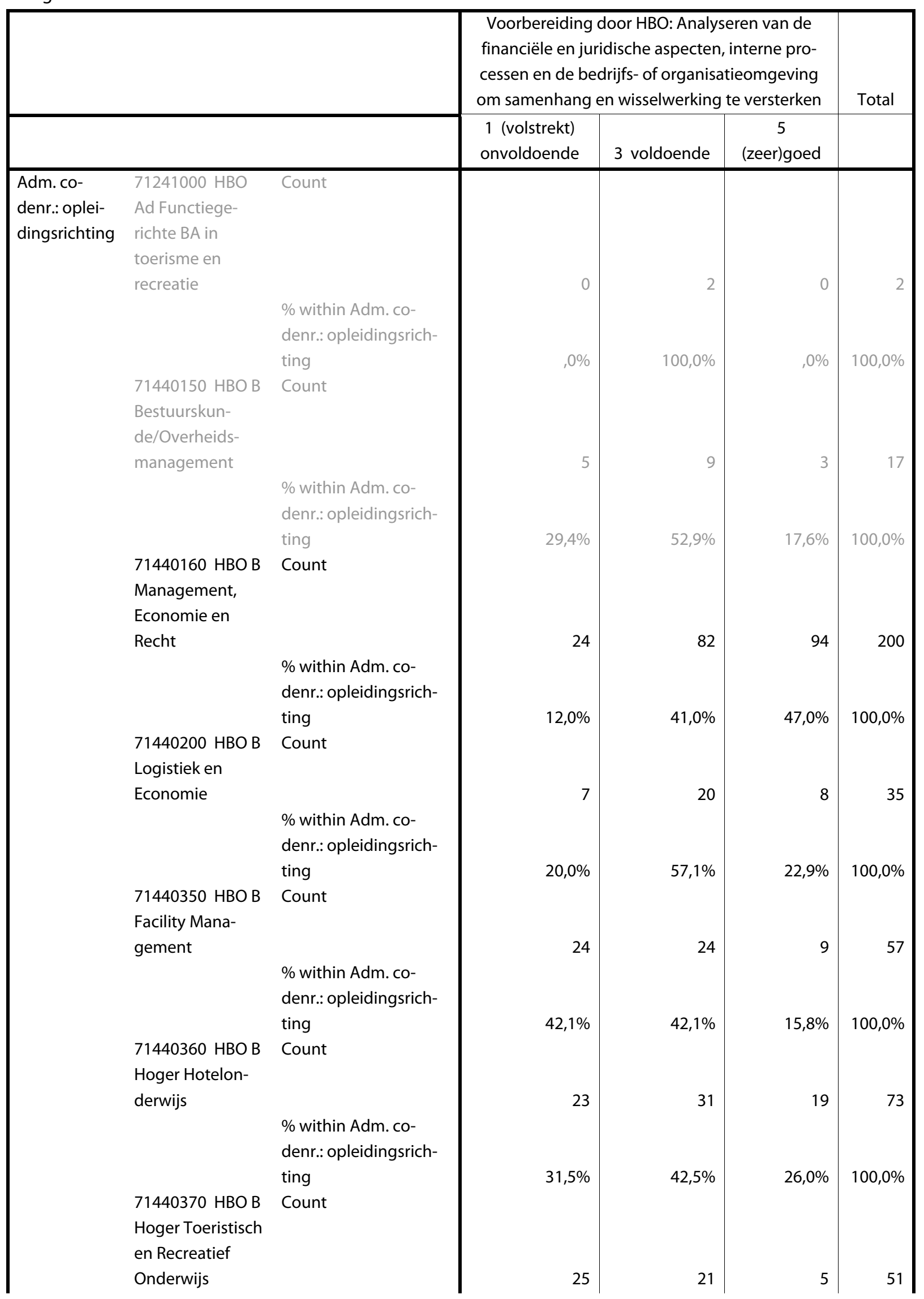




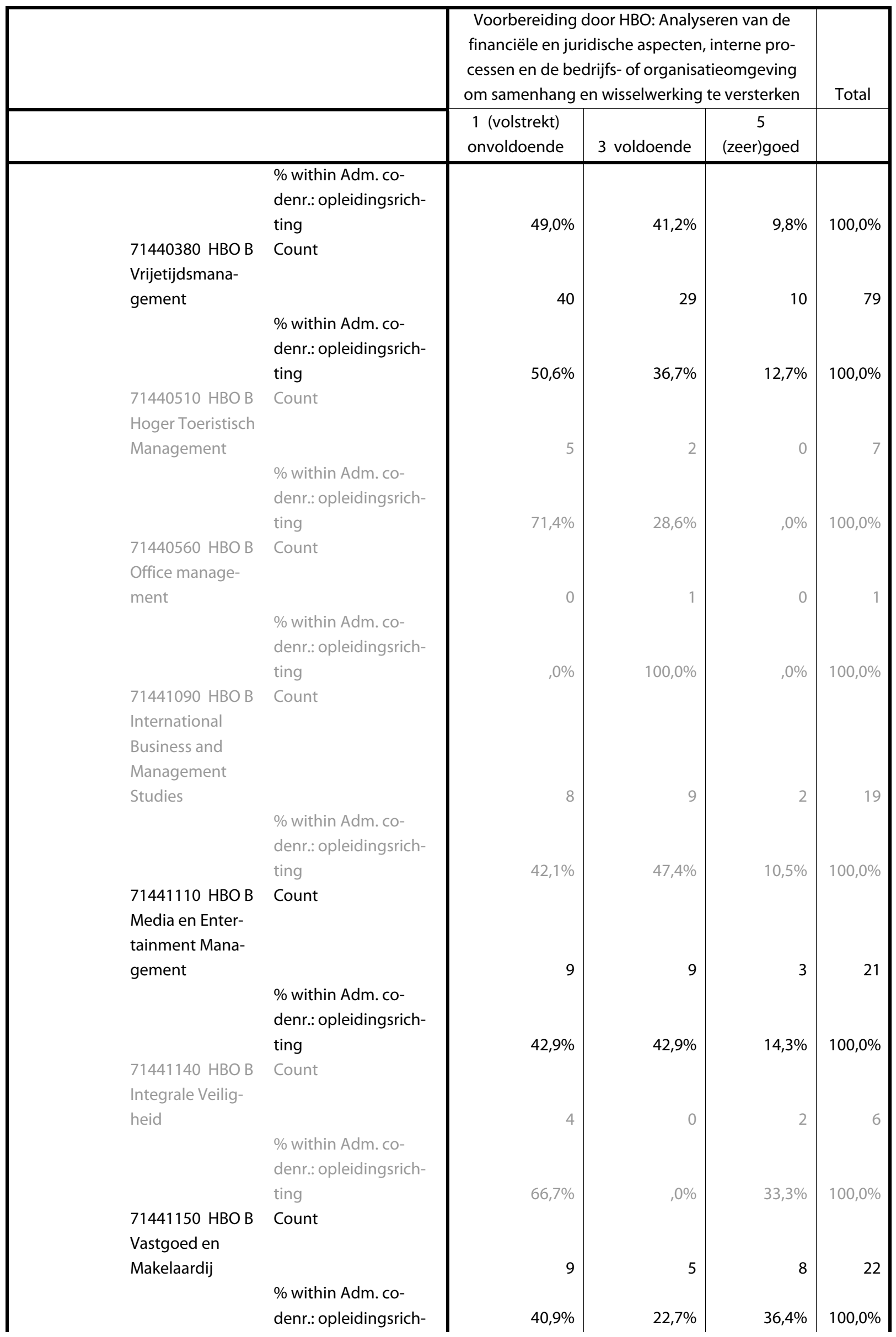




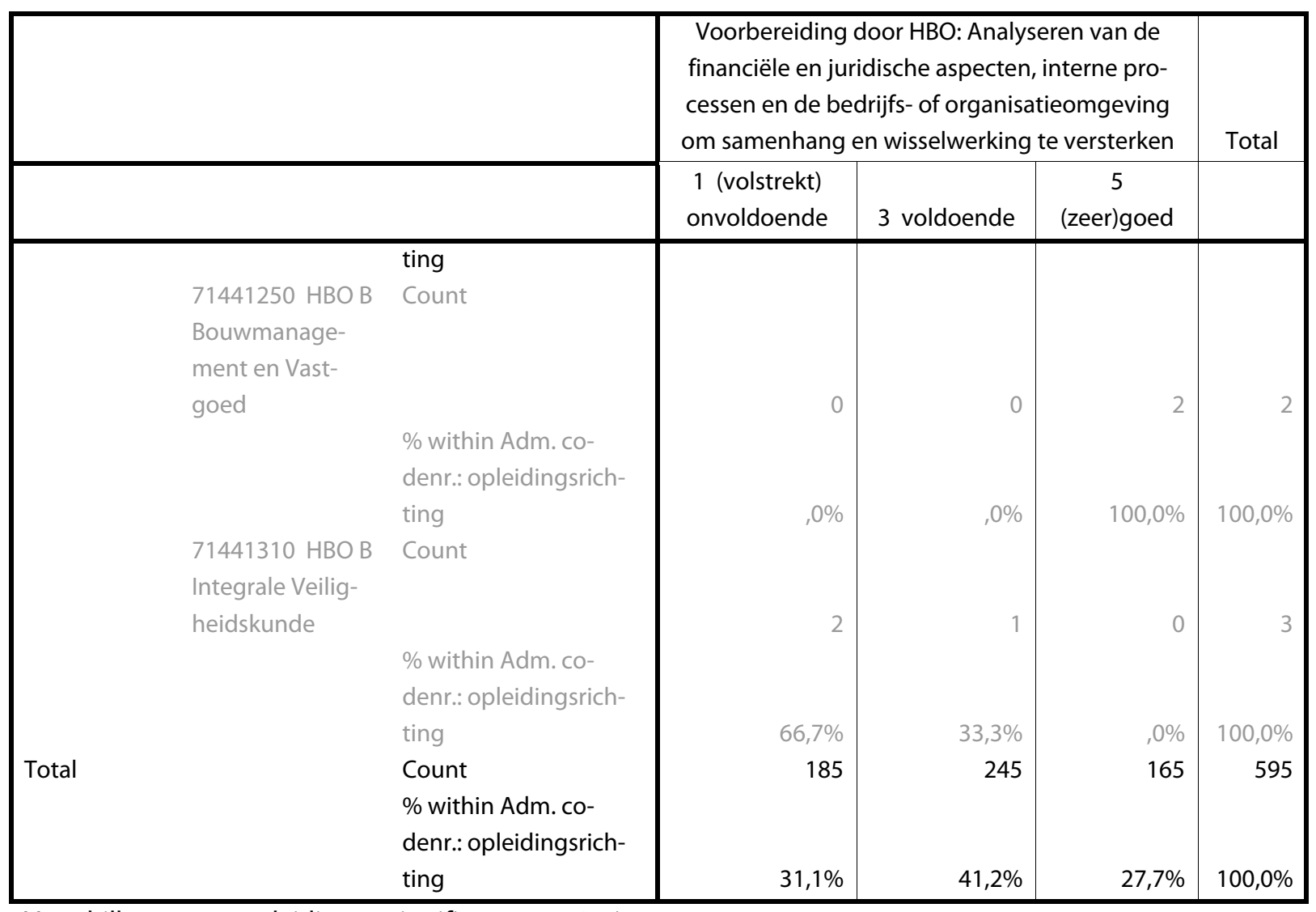

Verschillen tussen opleidingen significant op 1\%-niveau. 
Ontwikkelen, implementeren en evalueren van een veranderingsproces

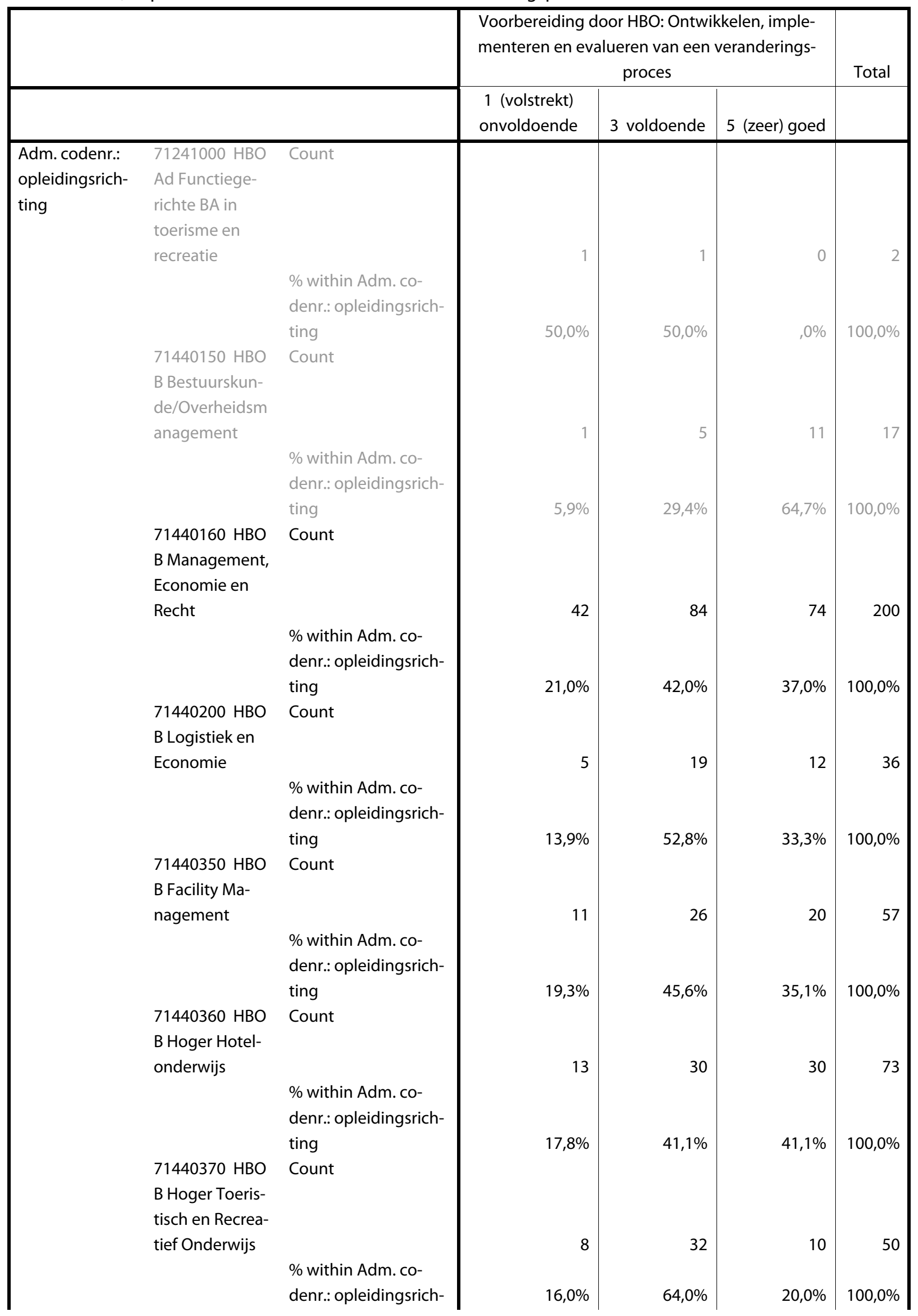




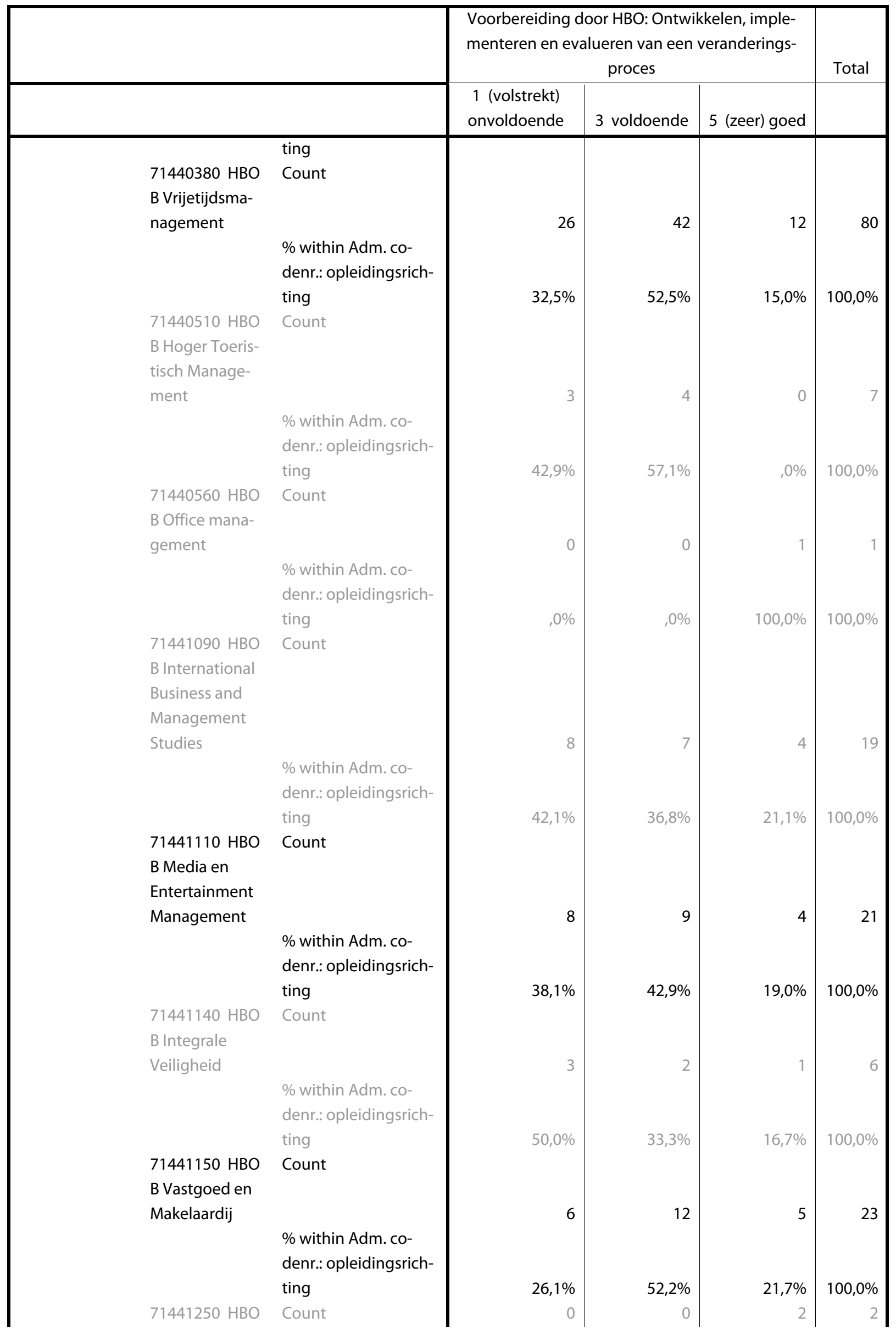




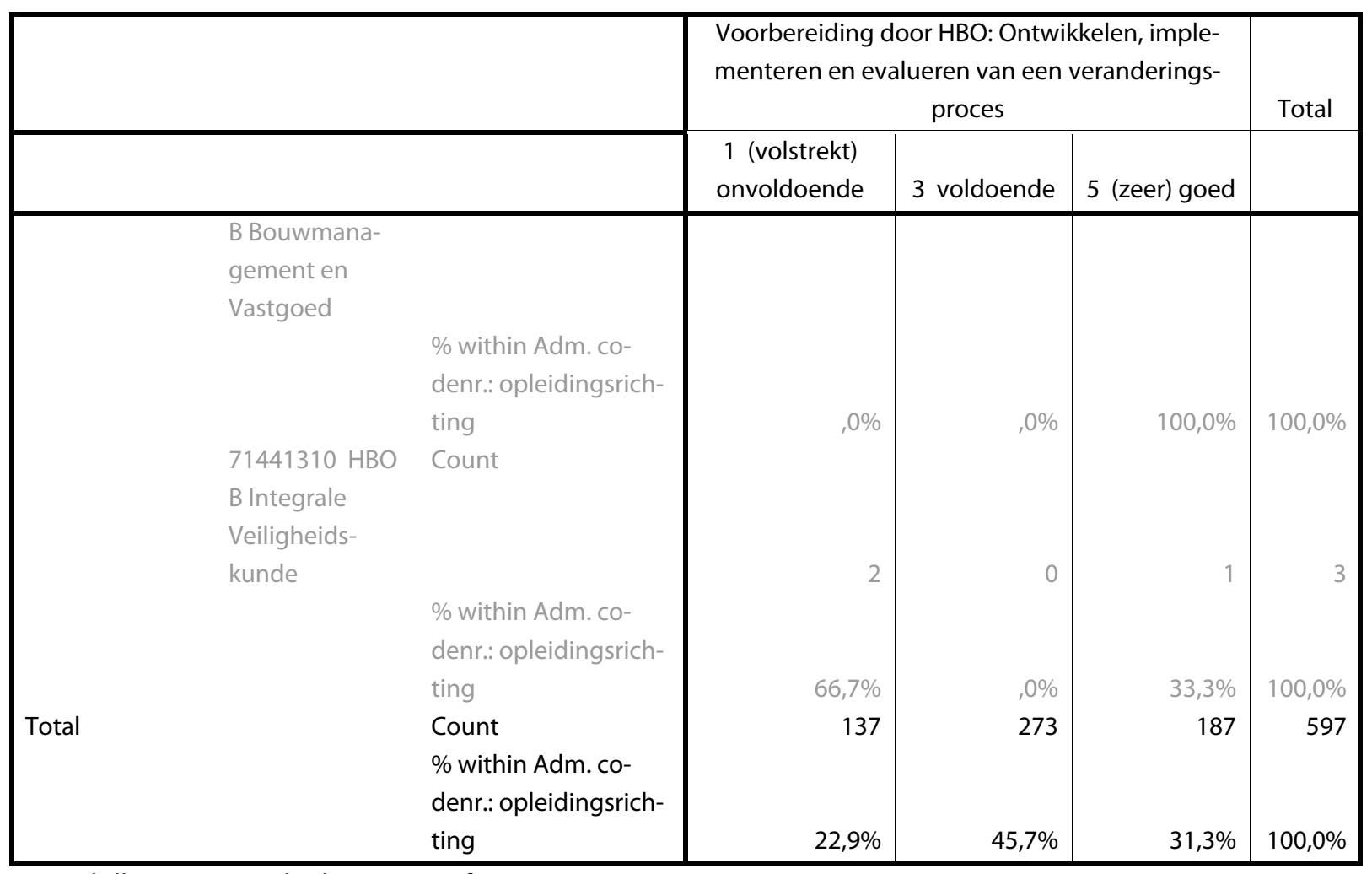

Verschillen tussen opleidingen significant op 1\%-niveau.

\subsection{Communications}

Opleidingen in de steekproef

\begin{tabular}{|c|c|c|c|c|c|}
\hline & & Frequency & Percent & Valid Percent & $\begin{array}{l}\text { Cumulative } \\
\text { Percent }\end{array}$ \\
\hline Valid & $\begin{array}{l}71440290 \text { HBO B Communicatie } \\
71440300 \text { HBO B Communicatie- } \\
\text { systemen } \\
71440310 \text { HBO B Hogere Europe- } \\
\text { se Beroepen Opleiding } \\
71440320 \text { HBO B Journalistiek en } \\
\text { Voorlichting } \\
71440330 \text { HBO B Journalistiek } \\
71441020 \text { HBO B Economisch- } \\
\text { linguïstisch } \\
\text { Total }\end{array}$ & $\begin{array}{r}27 \\
26 \\
1 \\
49 \\
\\
5 \\
283\end{array}$ & $\begin{array}{r}61,8 \\
9,5 \\
9,2 \\
, 4 \\
17,3 \\
1,8 \\
100,0\end{array}$ & $\begin{array}{r}9,2 \\
, 4 \\
17,3 \\
\\
1,8 \\
100,0\end{array}$ & $\begin{array}{l}61,8 \\
71,4 \\
80,6 \\
80,9 \\
98,2\end{array}$ \\
\hline
\end{tabular}




\subsubsection{Vereist niveau (Communications)}

\section{Onderzoeken communicatieprocessen}

Doen van onderzoek naar onderwerpen en/of communicatieprocessen [Onderzoeken]

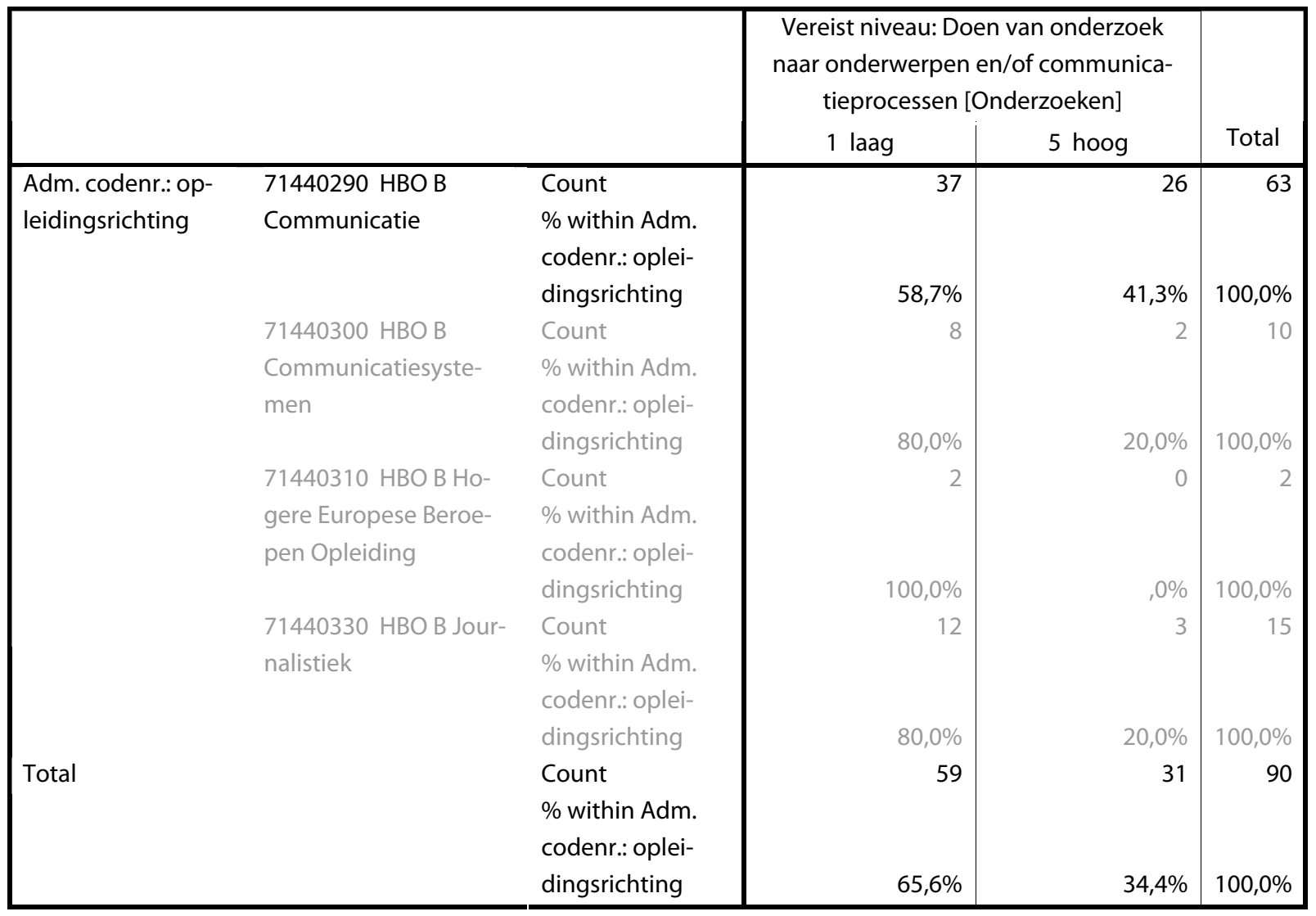




\section{Analyseren communicatieprocessen}

Analyseren van informatiebehoeften en communicatieprocessen in hun onderlinge samenhang en in de context van de internationale) omgeving [Analyseren]

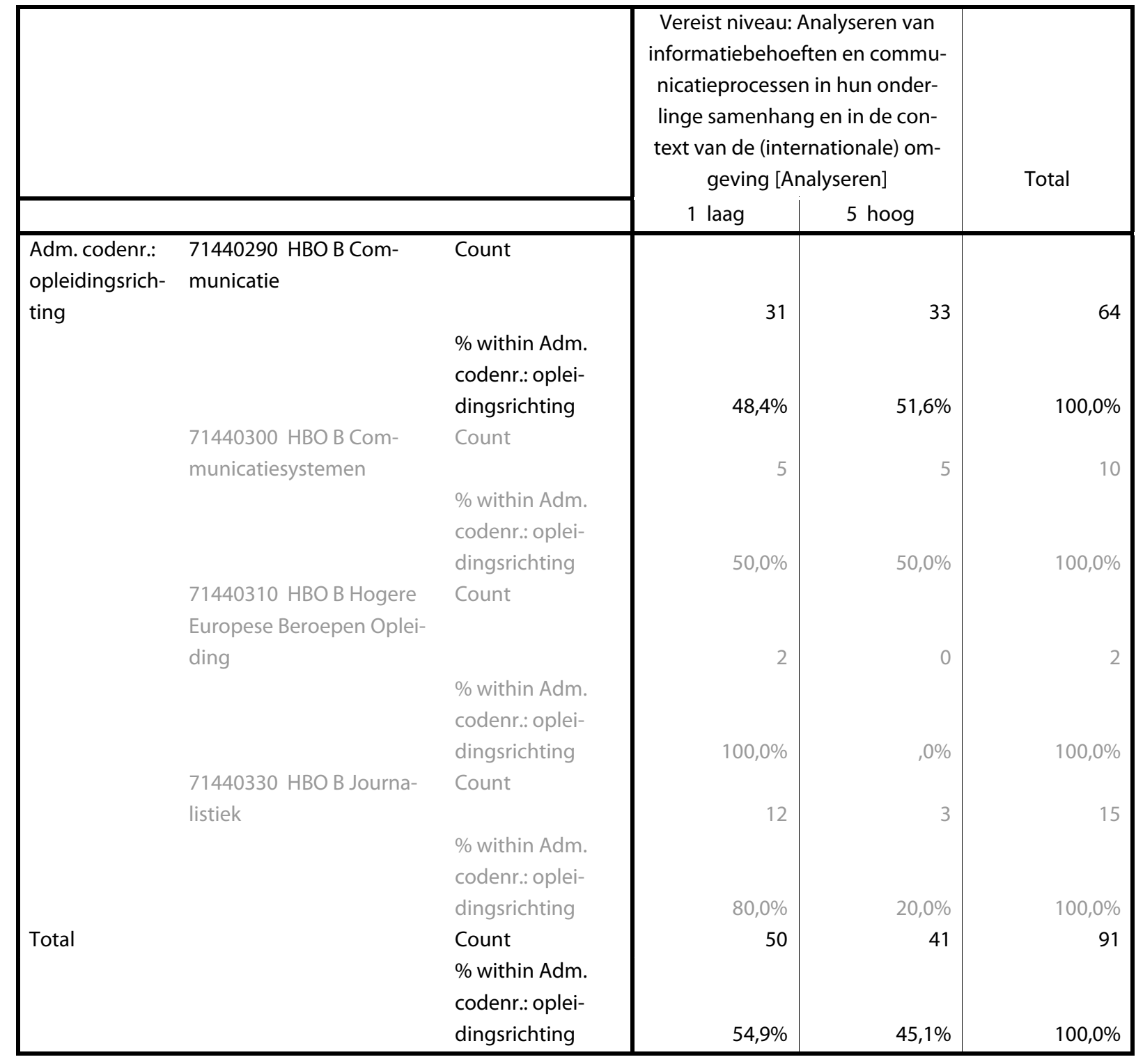




\section{Formelen en geven van advies}

Formuleren van of adviseren over de vorm en functies van een product, rekening houdend met (internationale) regels en conventies; doen hiervan in het Nederlands en/of in een of meer vreemde talen [Formuleren en Adviseren]

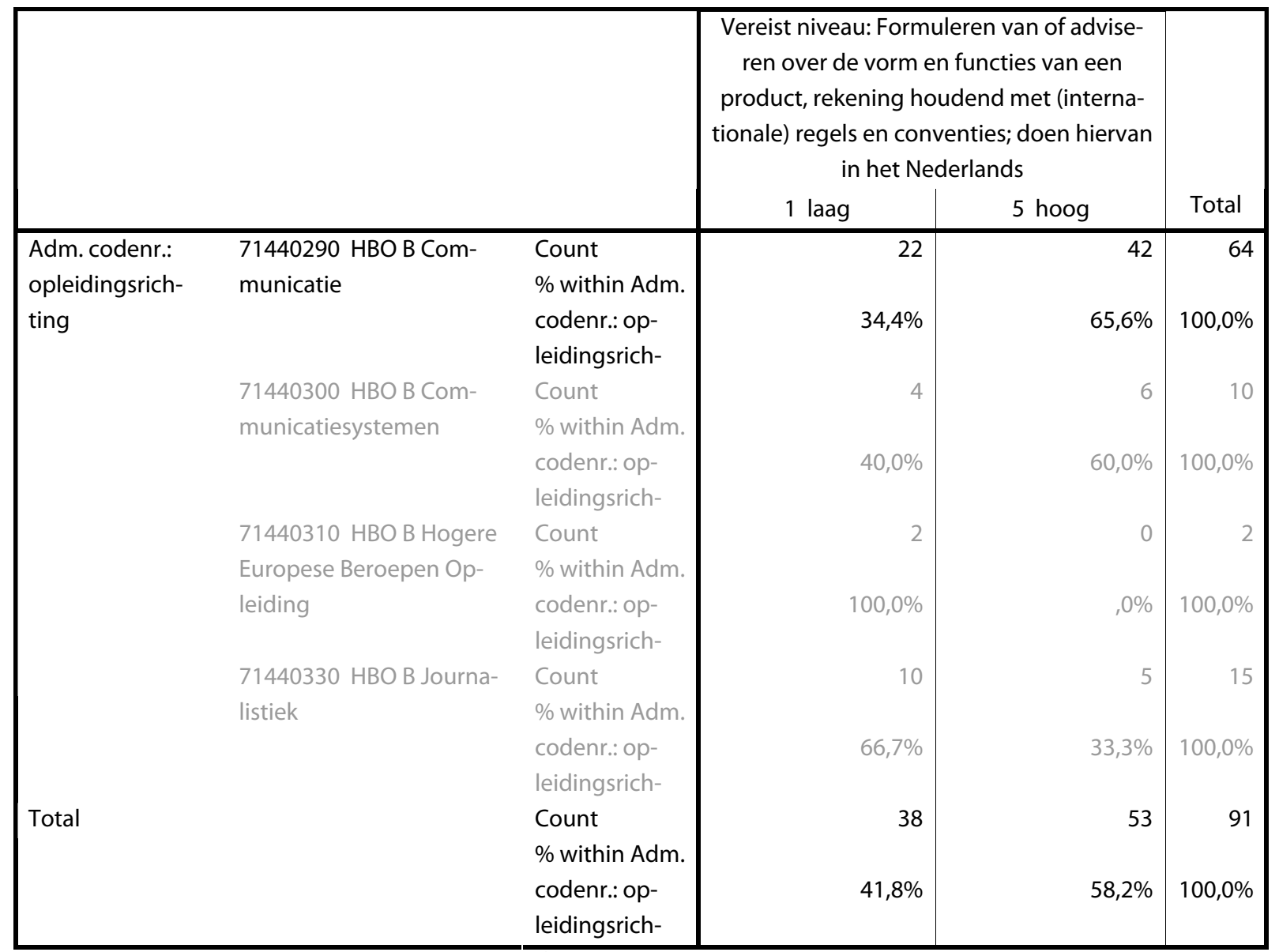

Verschillen tussen opleidingen significant op sioggniveau. 


\section{Ontwikkelen van producten en processen}

Ontwikkelen van een doelgroepgericht communicatie- en informatieproces of -product op basis van een strategisch beleidskader en/of andere gestelde kaders voor kwaliteit, doorlooptijd en budget, alsmede rekening houden met van toepassing zijnde(internationale) regels en conventies. [Ontwikkelen]

\begin{tabular}{|c|c|c|c|c|c|}
\hline & & & \multicolumn{2}{|c|}{$\begin{array}{l}\text { Vereist niveau: Ontwikkelen van een doel- } \\
\text { groepgericht communicatie- en informa- } \\
\text { tieproces of -product op basis van een } \\
\text { strategisch beleidskader en/of andere } \\
\text { gestelde kaders }\end{array}$} & \multirow[b]{2}{*}{ Total } \\
\hline & & & 1 laag & 5 hoog & \\
\hline \multirow[t]{4}{*}{$\begin{array}{l}\text { Adm. codenr.: } \\
\text { opleidingsrich- } \\
\text { ting }\end{array}$} & $\begin{array}{l}71440290 \text { HBO B Com- } \\
\text { municatie }\end{array}$ & $\begin{array}{l}\text { Count } \\
\% \text { within } \\
\text { Adm. codenr.: } \\
\text { opleidings- } \\
\text { richting }\end{array}$ & 29 & 35 & $\begin{array}{r}64 \\
100,0 \%\end{array}$ \\
\hline & $\begin{array}{l}71440300 \text { HBO B Com- } \\
\text { municatiesystemen }\end{array}$ & $\begin{array}{l}\text { Count } \\
\% \text { within } \\
\text { Adm. codenr.: } \\
\text { opleidings- } \\
\text { richting }\end{array}$ & $30,0 \%$ & $\begin{array}{r}7 \\
70,0 \%\end{array}$ & $\begin{array}{r}10 \\
100,0 \%\end{array}$ \\
\hline & $\begin{array}{l}71440310 \text { HBO B Hogere } \\
\text { Europese Beroepen Op- } \\
\text { leiding }\end{array}$ & $\begin{array}{l}\text { Count } \\
\% \text { within } \\
\text { Adm. codenr.: } \\
\text { opleidings- } \\
\text { richting }\end{array}$ & 2 & 0 & 2 \\
\hline & $\begin{array}{l}71440330 \text { HBO B Journa- } \\
\text { listiek }\end{array}$ & $\begin{array}{l}\text { Count } \\
\% \text { within } \\
\text { Adm. codenr.: } \\
\text { opleidings- } \\
\text { richting }\end{array}$ & $66,7 \%$ & 5 & 15 \\
\hline Total & & $\begin{array}{l}\text { Count } \\
\% \text { within } \\
\text { Adm. codenr.: } \\
\text { opleidings- } \\
\text { richting }\end{array}$ & $\begin{array}{r}44 \\
48,4 \%\end{array}$ & $\begin{array}{r}47 \\
51,6 \%\end{array}$ & 91 \\
\hline
\end{tabular}




\section{Realiseren van producten en processen}

Presenteren of op andere wijze onderwerpen aan een kritische toets door anderen van een communicatie/informatie product en/of communicatie/informatie processen [Realiseren]

\begin{tabular}{|c|c|c|c|c|c|}
\hline & & & \multicolumn{2}{|c|}{$\begin{array}{l}\text { Vereist niveau: Presenteren of op andere } \\
\text { wijze onderwerpen aan een kritische toets } \\
\text { door anderen van een communica- } \\
\text { tie/informatie product en/of communica- } \\
\text { tie/informatie }\end{array}$} & \multirow[t]{2}{*}{ Total } \\
\hline & & & 1 laag & 5 hoog & \\
\hline $\begin{array}{l}\text { Adm. codenr.: } \\
\text { opleidingsrich- } \\
\text { ting }\end{array}$ & $\begin{array}{l}71440290 \text { HBO B Com- } \\
\text { municatie } \\
71440300 \text { HBO B Com- } \\
\text { municatiesystemen } \\
\text { 71440310 HBO B Hogere } \\
\text { Europese Beroepen } \\
\text { Opleiding } \\
\text { 71440330 HBO B Journa- } \\
\text { listiek }\end{array}$ & $\begin{array}{l}\text { Count } \\
\text { \% within Adm. } \\
\text { codenr.: oplei- } \\
\text { dingsrichting } \\
\text { Count } \\
\text { \% within Adm. } \\
\text { codenr.: oplei- } \\
\text { dingsrichting } \\
\text { Count } \\
\text { \% within Adm. } \\
\text { codenr.: oplei- } \\
\text { dingsrichting } \\
\text { Count } \\
\text { \% within Adm. } \\
\text { codenr:: oplei- } \\
\text { dingsrichting } \\
\text { Count } \\
\text { \% within Adm. } \\
\text { codenr.: oplei- } \\
\text { dingsrichting }\end{array}$ & 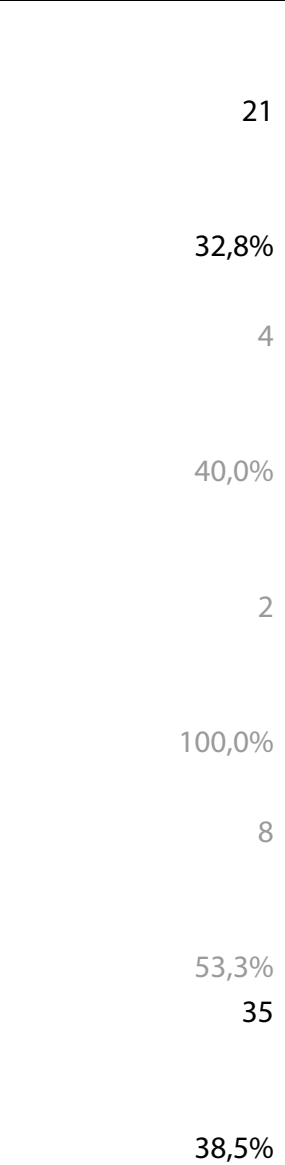 & 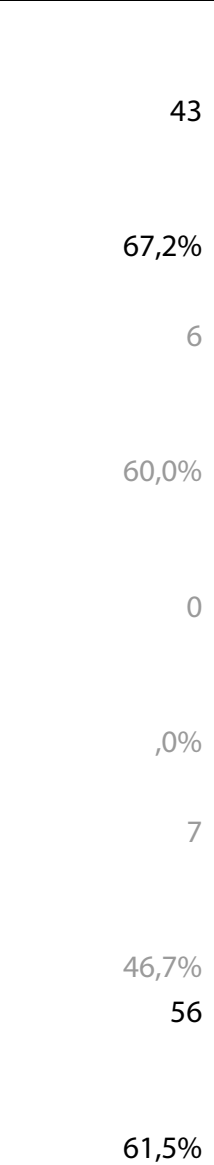 & $\begin{array}{r}100,0 \% \\
10 \\
2 \\
100,0 \% \\
\end{array}$ \\
\hline
\end{tabular}




\section{Evalueren van producten/processen}

Evalueren van communicatie/informatie producten en/of communicatie/informatie processen en voorstellen doen voor verbetering [Evalueren]

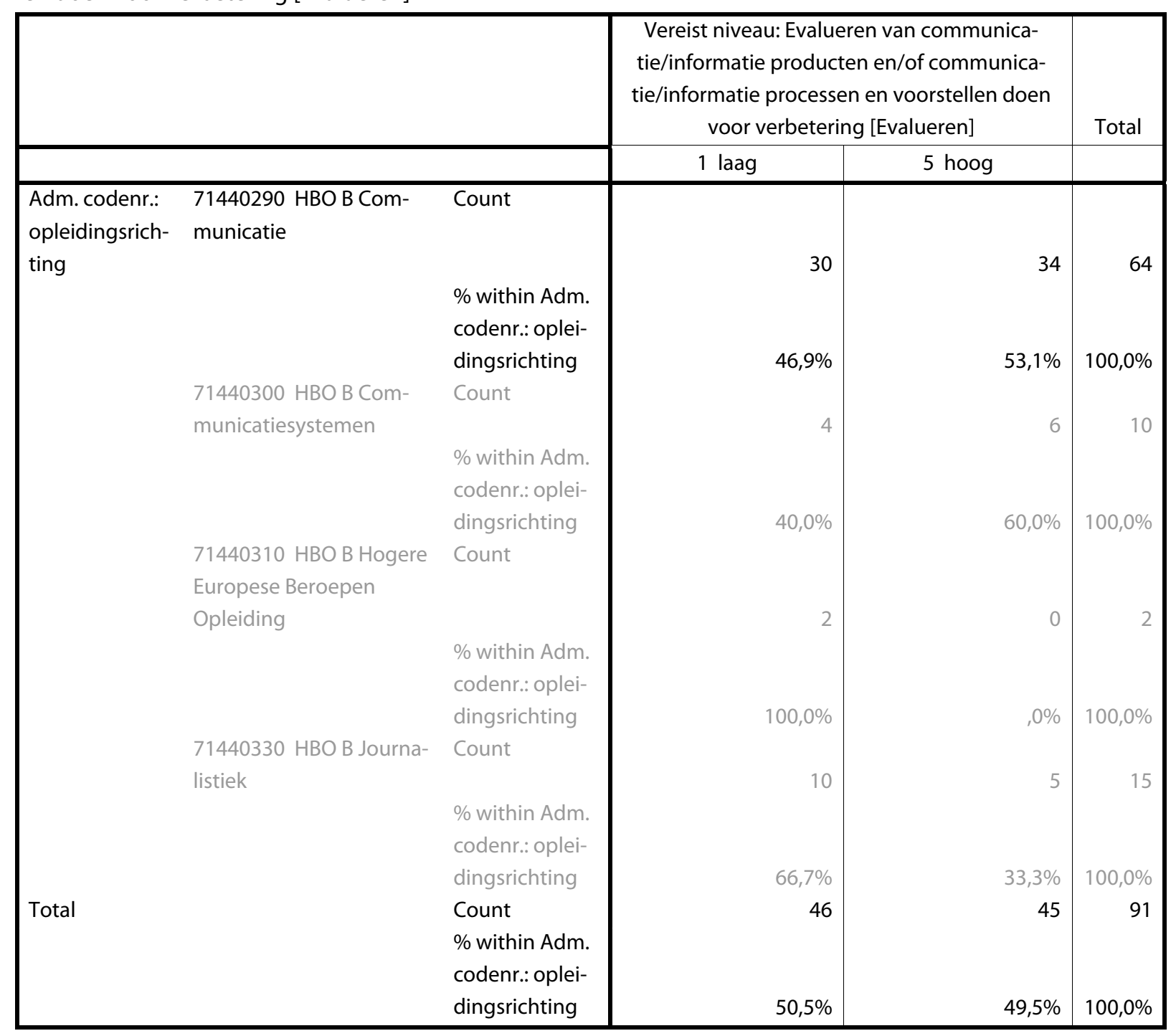




\section{Communiceren in interculturele context}

Vereist niveau: Communiceren in het Nederlands en/of in een of meer vreemde talen en toepassen van deze talen in een interculturele context in het kader van de andere domeincompetenties

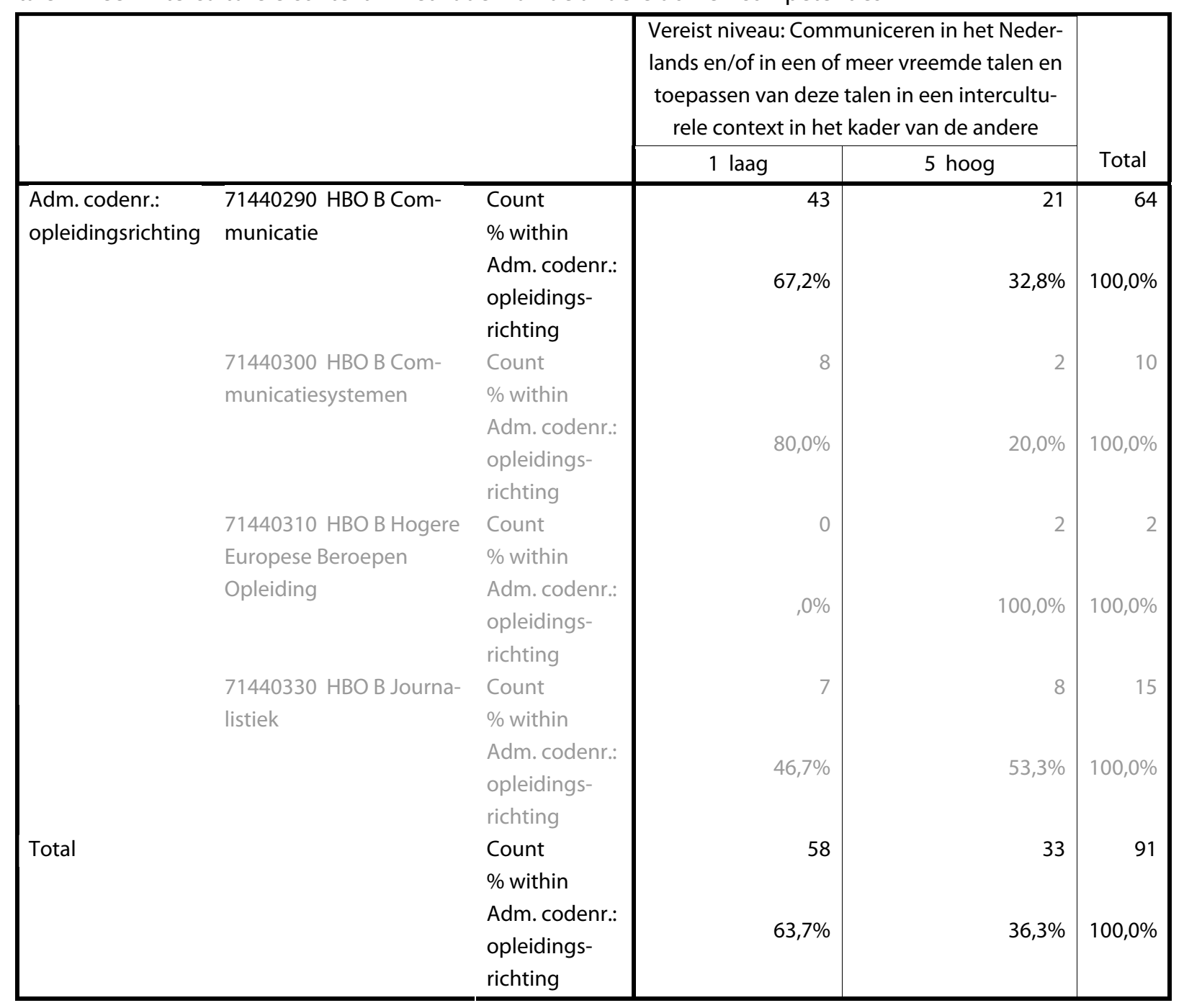




\subsubsection{Voorbereiding door hbo (Communications)}

\section{Onderzoeken communicatieprocessen}

Doen van onderzoek naar onderwerpen en/of communicatieprocessen [Onderzoeken]

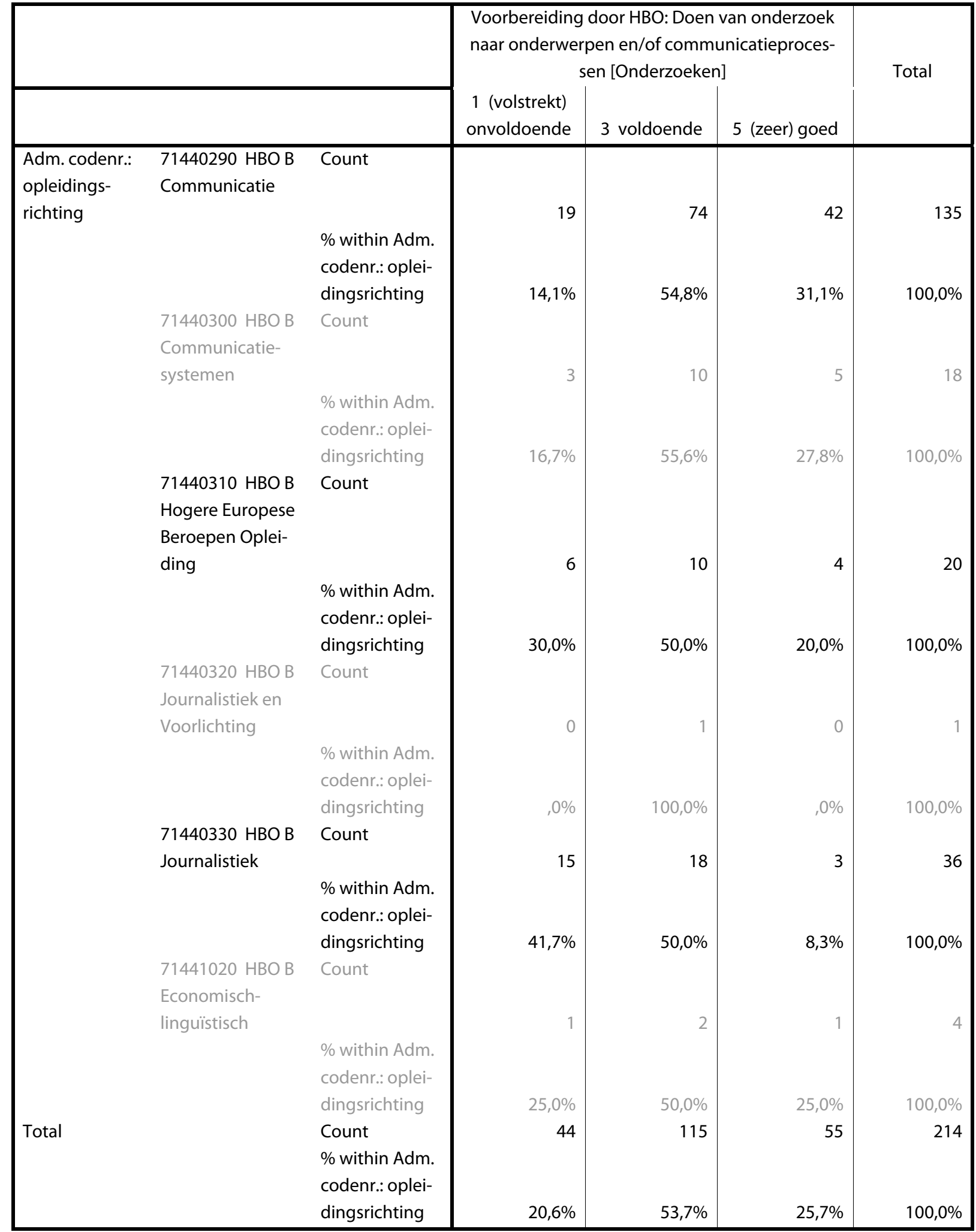

Verschillen tussen opleidingen significant op 5\%-niveau. 


\section{Analyseren communicatieprocessen}

Analyseren van informatiebehoeften en communicatieprocessen in hun onderlinge samenhang en in de context van de internationale) omgeving [Analyseren]

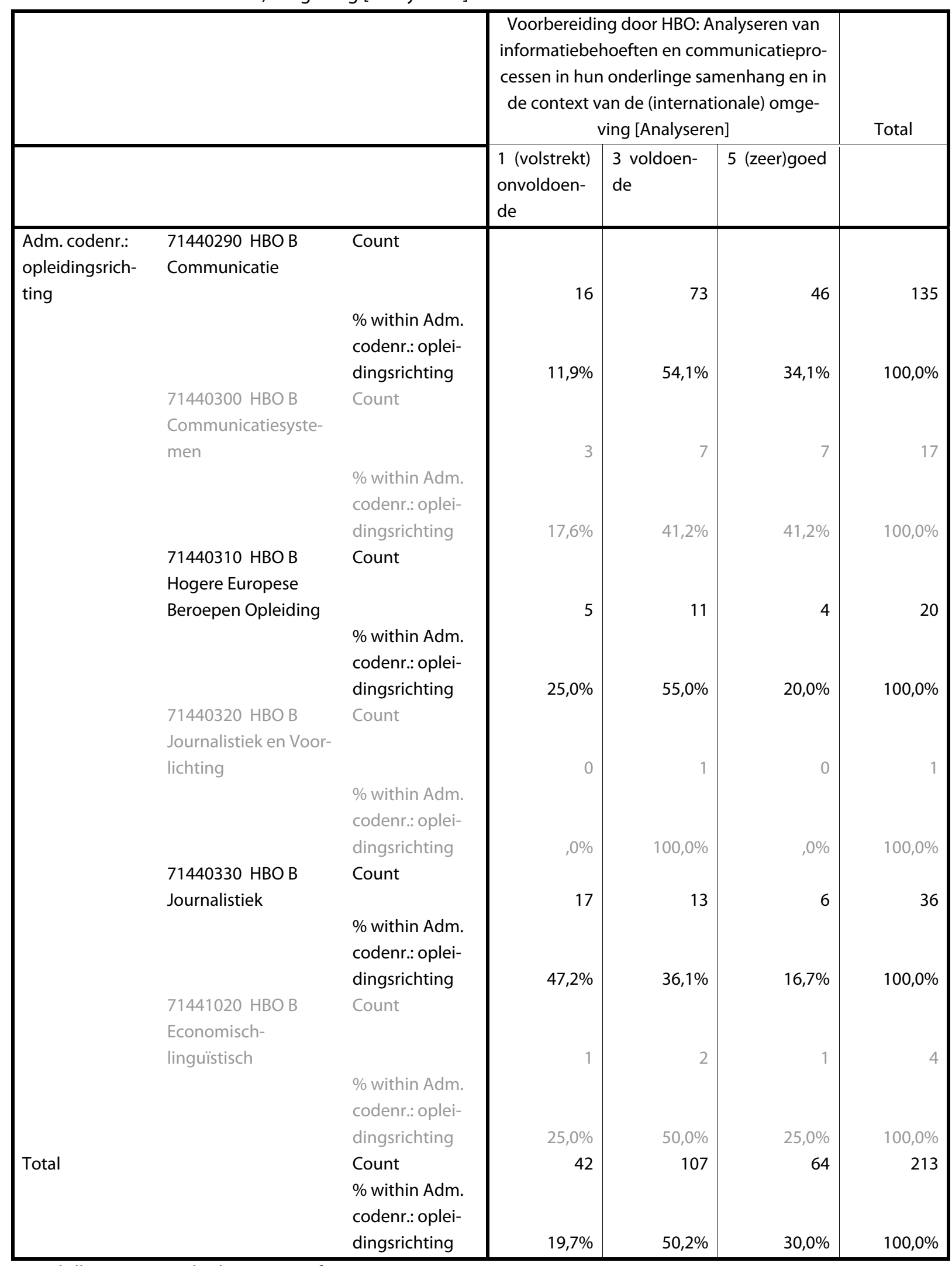

Verschillen tussen opleidingen significant op 1\%-niveau. 


\section{Formelen en geven van advies}

Formuleren van of adviseren over de vorm en functies van een product, rekening houdend met (internationale) regels en conventies; doen hiervan in het Nederlands en/of in een of meer vreemde talen [Formuleren en Adviseren]

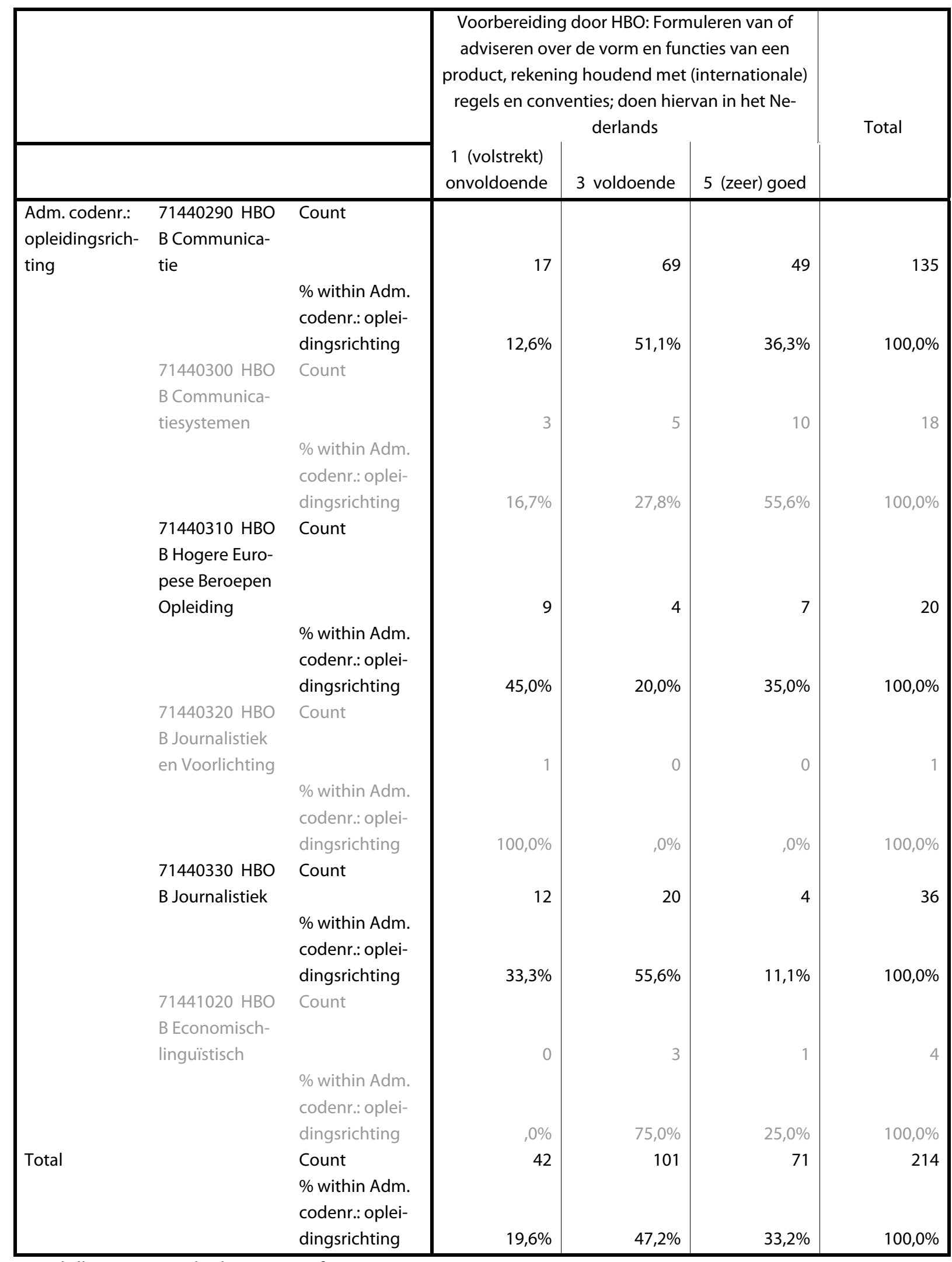

Verschillen tussen opleidingen significant op 1\%-niveau. 


\section{Ontwikkelen van producten en processen}

Ontwikkelen van een doelgroepgericht communicatie- en informatieproces of -product op basis van een strategisch beleidskader en/of andere gestelde kaders voor kwaliteit, doorlooptijd en budget, alsmede rekening houden met van toepassing zijnde(internationale) regels en conventies. [Ontwikkelen]

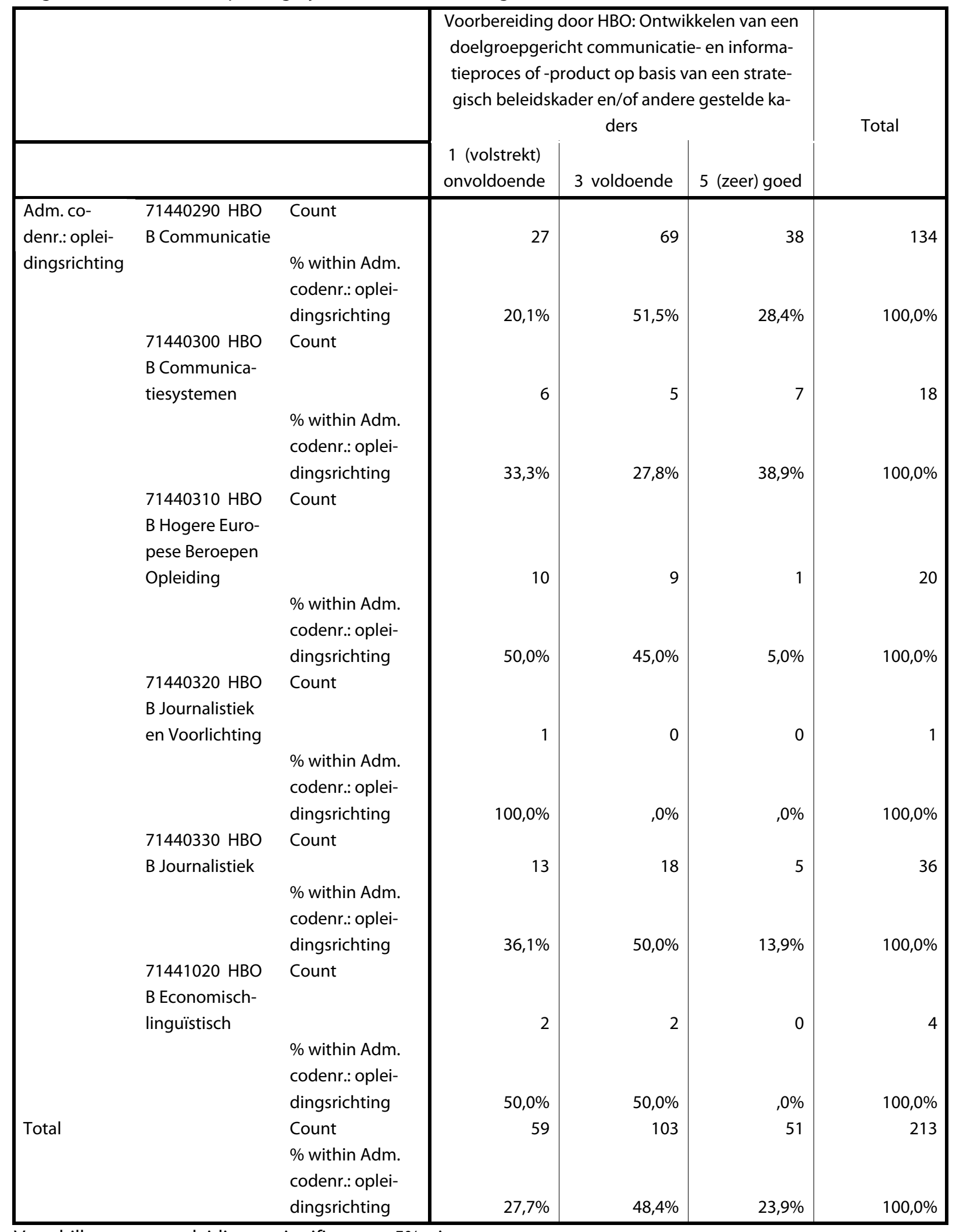

Verschillen tussen opleidingen significant op 5\%-niveau. 


\section{Realiseren van producten en processen}

Presenteren of op andere wijze onderwerpen aan een kritische toets door anderen van een communicatie/informatie product en/of communicatie/informatie processen [Realiseren]

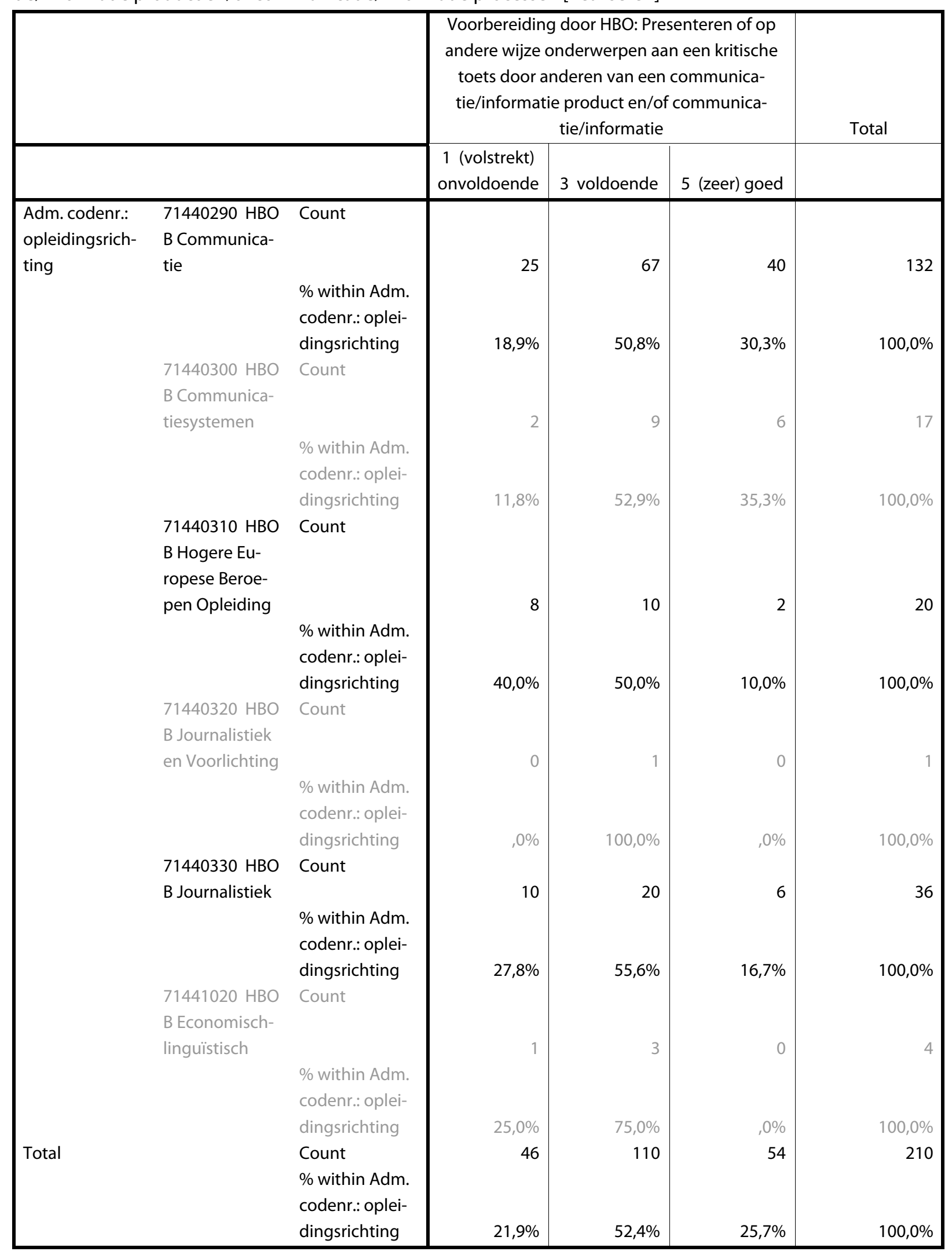




\section{Evalueren van producten/processen}

Evalueren van communicatie/informatie producten en/of communicatie/informatie processen en voorstellen doen voor verbetering [Evalueren]

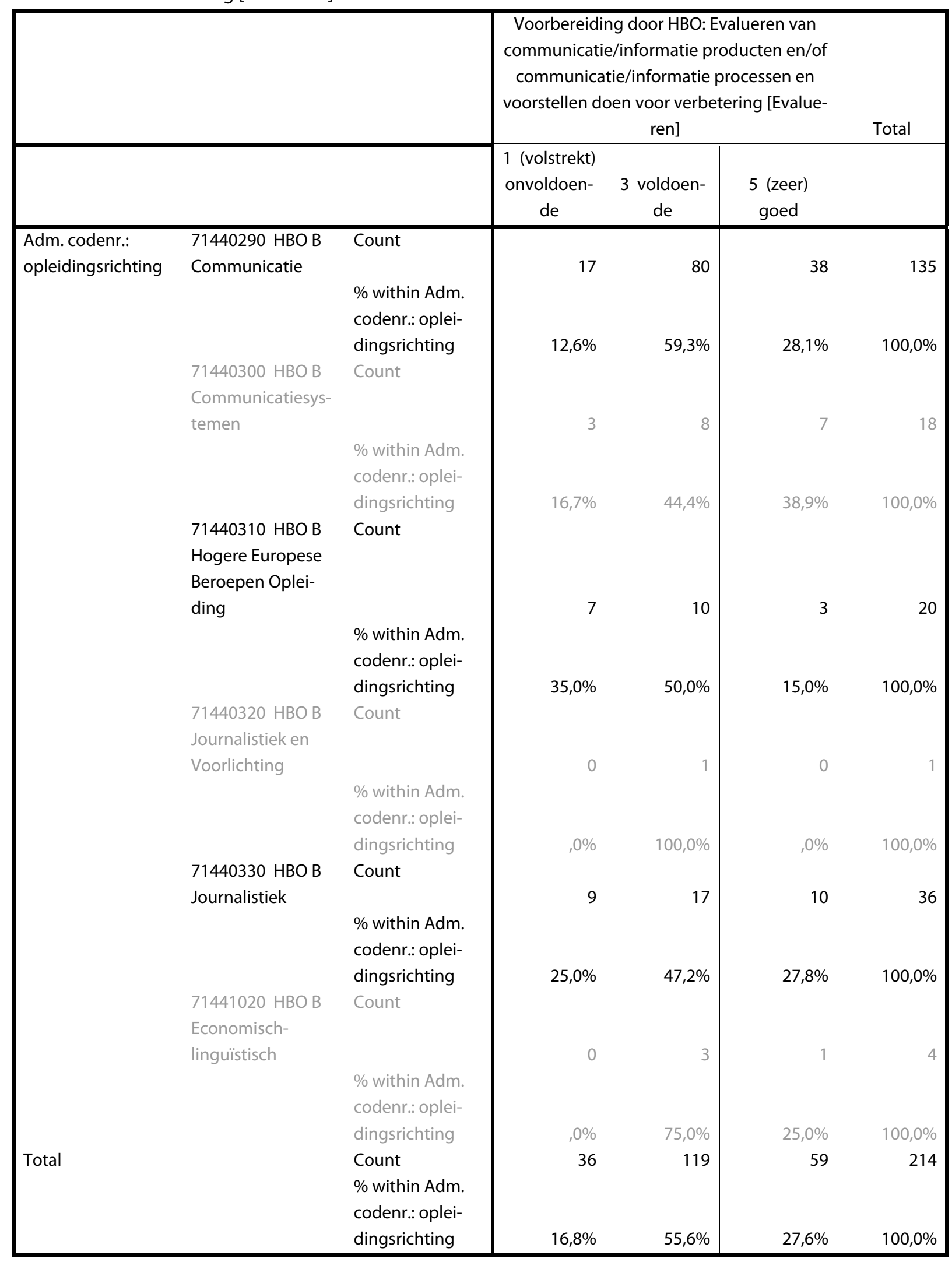




\section{Communiceren in interculturele context}

Vereist niveau: Communiceren in het Nederlands en/of in een of meer vreemde talen en toepassen van deze talen in een interculturele context in het kader van de andere domeincompetenties

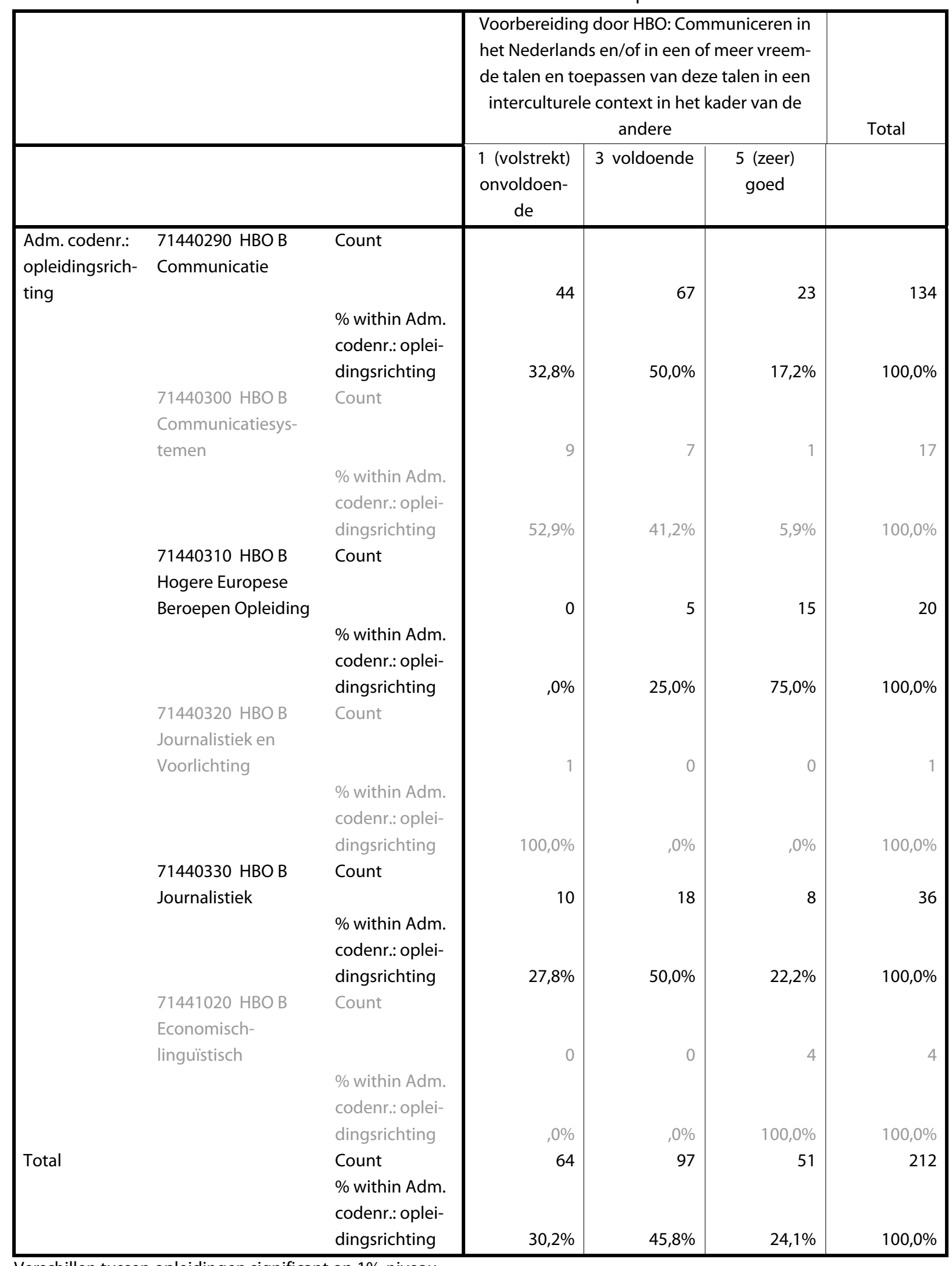

Verschillen tussen opleidingen significant op 1\%-niveau. 


\subsection{Law}

Opleidingen in de steekproef

\begin{tabular}{|c|c|c|c|c|c|}
\hline & & Frequency & Percent & Valid Percent & $\begin{array}{c}\text { Cumulative Per- } \\
\text { cent }\end{array}$ \\
\hline Valid & $\begin{array}{l}71441160 \text { HBO B Juridische } \\
\text { opleiding }\end{array}$ & 10 & 100,0 & 100,0 & 100,0 \\
\hline
\end{tabular}

Vanwege het kleine aantal in de steekproef worden in deze paragraaf geen nadere cijfers voor het domein Law gepresenteerd.

\subsection{Information and Communication Technology}

Opleidingen in de steekproef

\begin{tabular}{|c|c|c|c|c|c|}
\hline & & Frequency & Percent & Valid Percent & $\begin{array}{c}\text { Cumulative Per- } \\
\text { cent }\end{array}$ \\
\hline \multirow[t]{4}{*}{ Valid } & $\begin{array}{l}71144000 \text { HBO Kort Bedrijfskun- } \\
\text { dige informatica }\end{array}$ & 2 & 2,9 & 2,9 & 2,9 \\
\hline & $\begin{array}{l}71440140 \text { HBO B Bedrijfskundige } \\
\text { Informatica }\end{array}$ & 60 & 87,0 & 87,0 & 89,9 \\
\hline & $\begin{array}{l}71440270 \text { HBO B Informatie- } \\
\text { dienstverlening en -management }\end{array}$ & 7 & 10,1 & 10,1 & 100,0 \\
\hline & Total & 69 & 100,0 & 100,0 & \\
\hline
\end{tabular}




\subsubsection{Vereist niveau (Information and Communication Technology)}

\section{Analyseren van processen, producten en informatiestromen}

Voert een analyse uit van processen, producten en informatiestromen in hun onderlinge samenhang en de context van de omgeving. Stelt functionele specificaties op

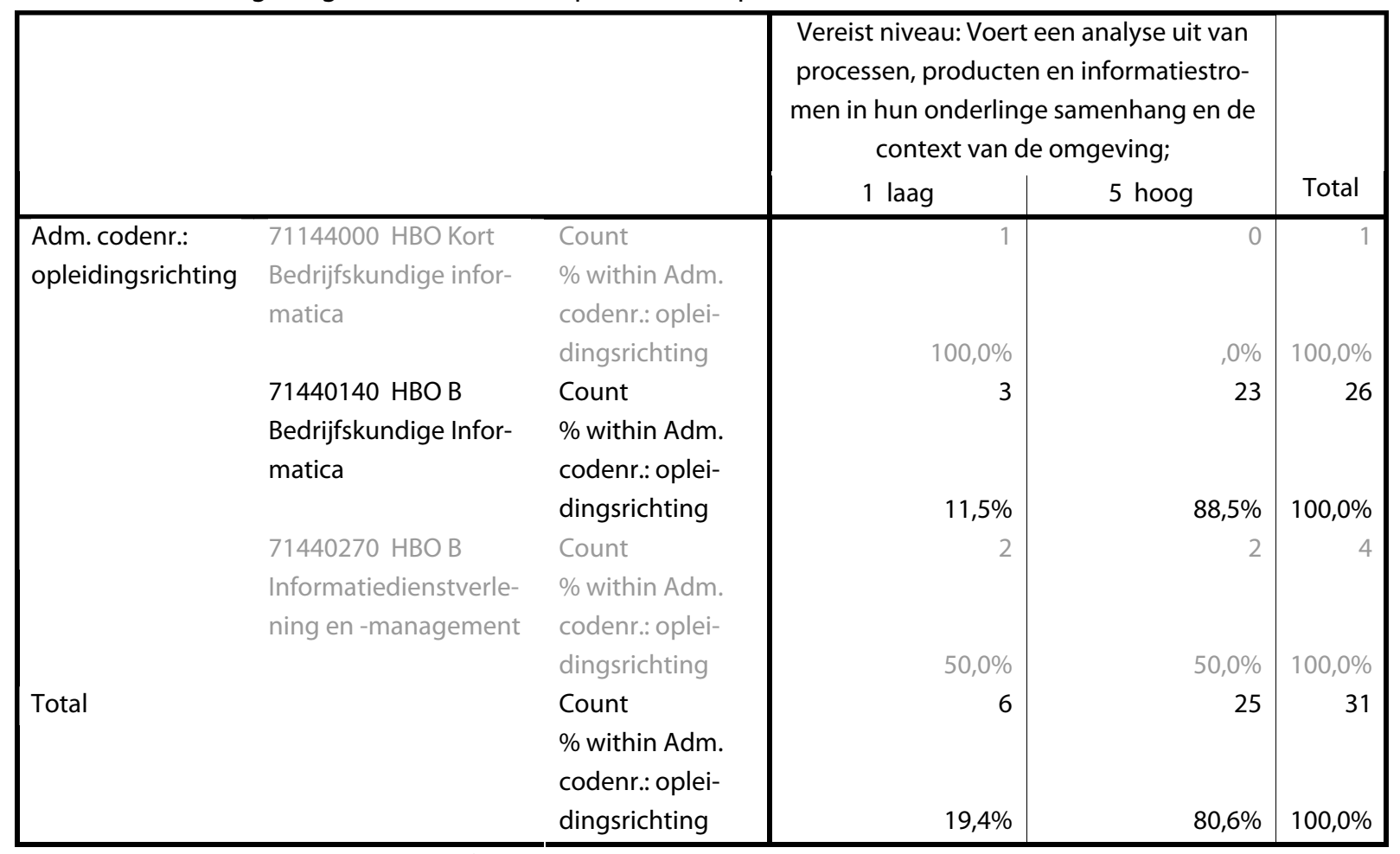

Verschillen tussen opleidingen significant op 5\%-niveau. 


\section{Adviseren m.b.t. processen, informatiestromen of ict-systemen}

Formuleert op basis van een analyse en in overleg met stakeholders een onderbouwd advies voor de herinrichting van processen en/of informatiestromen en voor een nieuw te ontwikkelen of aan te schaffen ictsysteem. Betrekt hierin financiële aspecten, tijdsaspecten, de organisatie(verandering), haalbaarheid en risico's en mogelijkheden voor outsourcing

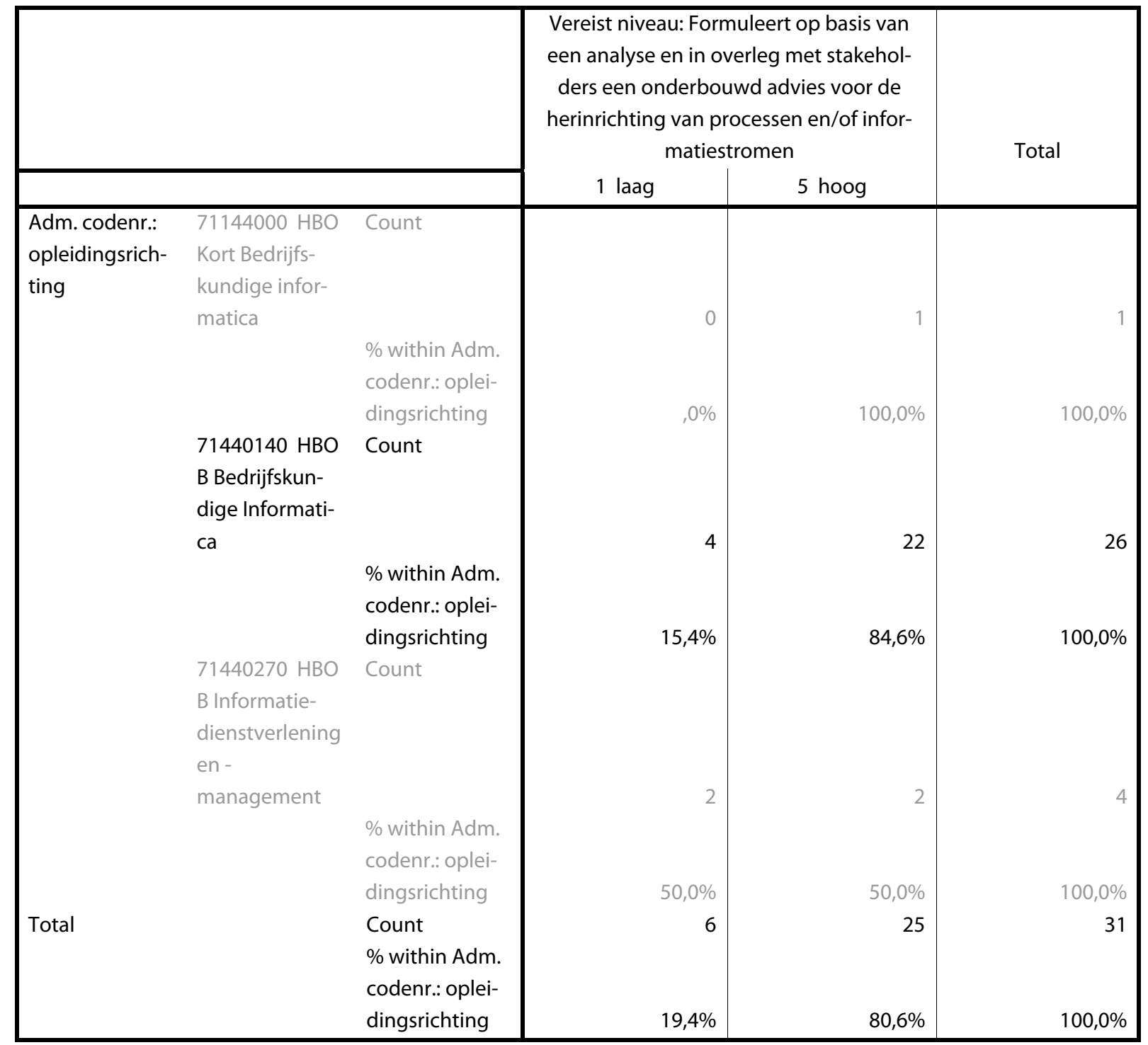




\section{Ontwerpen van ict-systemen}

Ontwerpt een ict-systeem op basis van een architectuurbeschrijving en specificaties, in samenhang met een analyse en binnen de gestelde kaders voor kwaliteit, testen, beveiliging, doorlooptijd, budget en exploitatie en beheer

\begin{tabular}{|c|c|c|c|c|c|}
\hline & & & $\begin{array}{r}\text { Vereist niveau: } \\
\text { systeem op basi } \\
\text { tuurbeschrijving } \\
\text { samenhang m } \\
\text { binnen de ges }\end{array}$ & $\begin{array}{l}\text { erpt een ict- } \\
\text { een architec- } \\
\text { ecificaties, in } \\
\text { analyse en } \\
\text { kaders voor }\end{array}$ & Total \\
\hline & & & 1 laag & 5 hoog & \\
\hline $\begin{array}{l}\text { Adm. codenr.: } \\
\text { opleidingsrich- } \\
\text { ting }\end{array}$ & $\begin{array}{l}71144000 \text { HBO } \\
\text { Kort Bedrijfskun- } \\
\text { dige informatica } \\
71440140 \text { HBO B } \\
\text { Bedrijfskundige } \\
\text { Informatica } \\
\\
\text { 71440270 HBO B } \\
\text { Informatiedienst- } \\
\text { verlening en - } \\
\text { management }\end{array}$ & $\begin{array}{l}\text { Count } \\
\text { \% within Adm. } \\
\text { codenr.: oplei- } \\
\text { dingsrichting } \\
\text { Count } \\
\text { \% within Adm. } \\
\text { codenr.: oplei- } \\
\text { dingsrichting } \\
\text { Count } \\
\text { \% within Adm. } \\
\text { codenr.: oplei- } \\
\text { dingsrichting } \\
\text { Count } \\
\text { \% within Adm. } \\
\text { codenr.: oplei- } \\
\text { dingsrichting }\end{array}$ & $\begin{array}{r}1 \\
100,0 \% \\
16 \\
61,5 \% \\
\\
3 \\
75,0 \% \\
20 \\
64,5 \%\end{array}$ & 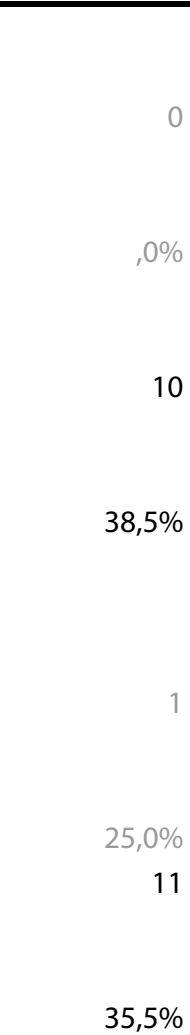 & $\begin{array}{r}1 \\
100,0 \% \\
26 \\
\\
100,0 \% \\
\\
4 \\
\\
\\
\\
\\
\\
\\
\\
\\
\\
\\
\\
100,0 \% \\
\end{array}$ \\
\hline
\end{tabular}




\section{Realiseren van ict-systemen}

Bouwt en implementeert een ict-systeem op basis van een functioneel en technisch ontwerp en binnen de gestelde kaders voor kwaliteit, testen, beveiliging, doorlooptijd, budget en exploitatie en beheer

\begin{tabular}{|c|c|c|c|c|c|}
\hline & & & \multicolumn{2}{|c|}{$\begin{array}{l}\text { Vereist niveau: Bouwt en implemen- } \\
\text { teert een ict-systeem op basis van een } \\
\text { functioneel en technisch ontwerp en } \\
\text { binnen de gestelde kaders voor kwali- } \\
\text { teit, testen, beveiliging, }\end{array}$} & \multirow[b]{2}{*}{ Total } \\
\hline & & & 1 laag & 5 hoog & \\
\hline \multirow[t]{3}{*}{$\begin{array}{l}\text { Adm. codenr:: } \\
\text { opleidingsrich- } \\
\text { ting }\end{array}$} & $\begin{array}{l}71144000 \text { HBO Kort Be- } \\
\text { drijfskundige informatica }\end{array}$ & $\begin{array}{l}\text { Count } \\
\text { \% within Adm. } \\
\text { codenr.: oplei- } \\
\text { dingsrichting } \\
\text { Count }\end{array}$ & $\begin{array}{r}0 \\
, 0 \% \\
19\end{array}$ & $\begin{array}{r}100,0 \% \\
7\end{array}$ & $\begin{array}{r}100,0 \% \\
26\end{array}$ \\
\hline & kundige Informatica & $\begin{array}{l}\% \text { within Adm. } \\
\text { codenr.: oplei- } \\
\text { dingsrichting }\end{array}$ & $73,1 \%$ & $26,9 \%$ & $100,0 \%$ \\
\hline & $\begin{array}{l}71440270 \text { HBO B Informa- } \\
\text { tiedienstverlening en - } \\
\text { management }\end{array}$ & $\begin{array}{l}\text { Count } \\
\% \text { within Adm. } \\
\text { codenr.: oplei- } \\
\text { dingsrichting }\end{array}$ & $\begin{array}{r}3 \\
75,0 \%\end{array}$ & $\begin{array}{r}1 \\
25,0 \%\end{array}$ & $\begin{array}{r}4 \\
100,0 \%\end{array}$ \\
\hline Total & & $\begin{array}{l}\text { Count } \\
\% \text { within Adm. } \\
\text { codenr.: oplei- } \\
\text { dingsrichting }\end{array}$ & $\begin{array}{r}22 \\
71,0 \%\end{array}$ & $\begin{array}{r}9 \\
29,0 \%\end{array}$ & $\begin{array}{r}31 \\
100,0 \%\end{array}$ \\
\hline
\end{tabular}




\section{Beheren van ict-systemen}

Geeft vorm aan de exploitatie en het beheer van ict-systemen. Zorgt voor invoeren, testen, integreren en inbedrijfstelling van een nieuw(e release van een) ict-systeem. Verleent diensten die zijn overeengekomen (in een Service Level Agreement) binnen de gestelde kaders voor kwaliteit en financiën. Zorgt in samenhang met ontwerp en bouw voor het onderhoud van ict-systemen

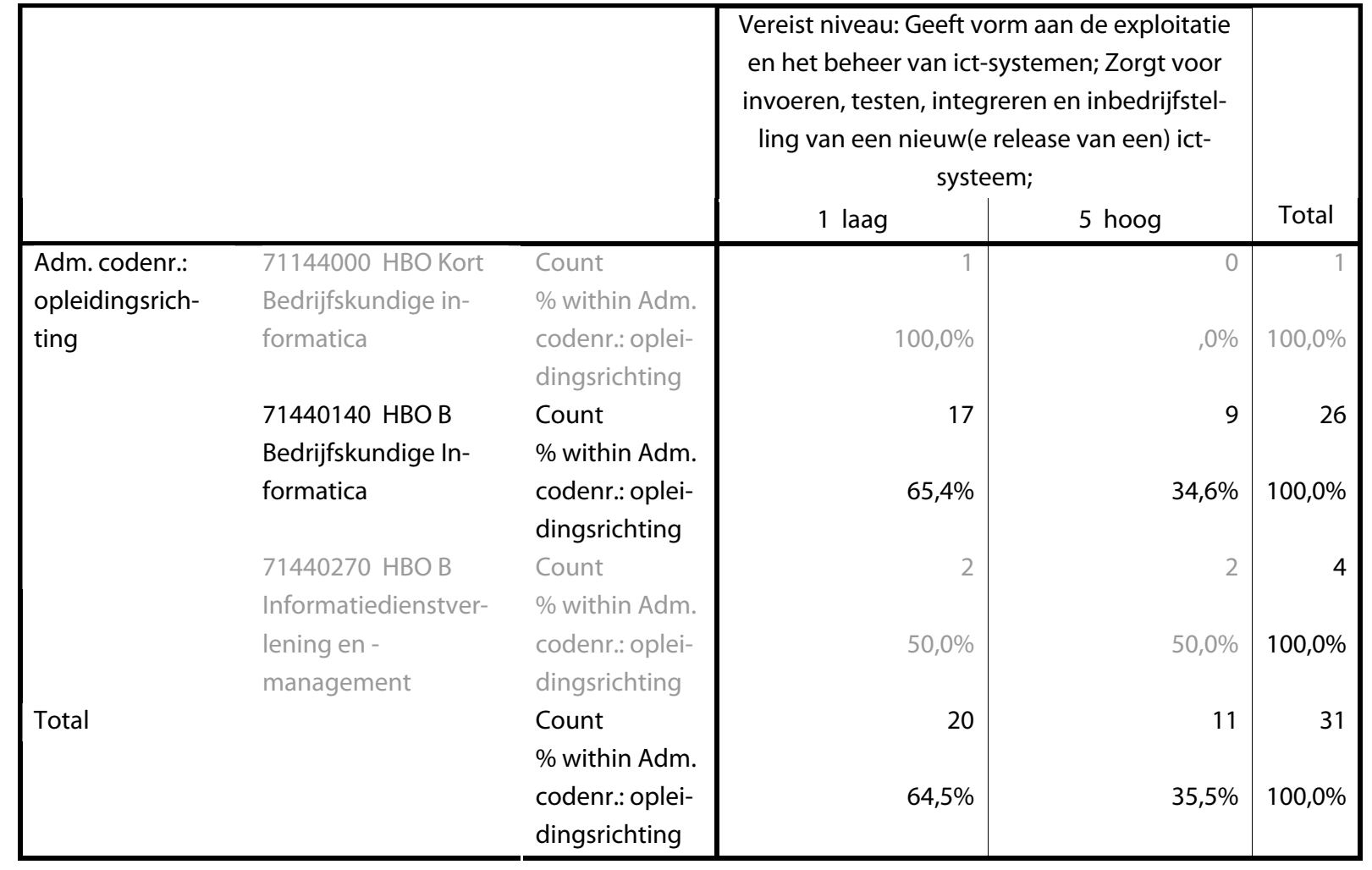




\subsubsection{Voorbereiding door hbo (Information and Communication Technolo- gy)}

\section{Analyseren van processen, producten en informatiestromen}

Voert een analyse uit van processen, producten en informatiestromen in hun onderlinge samenhang en de context van de omgeving. Stelt functionele specificaties op

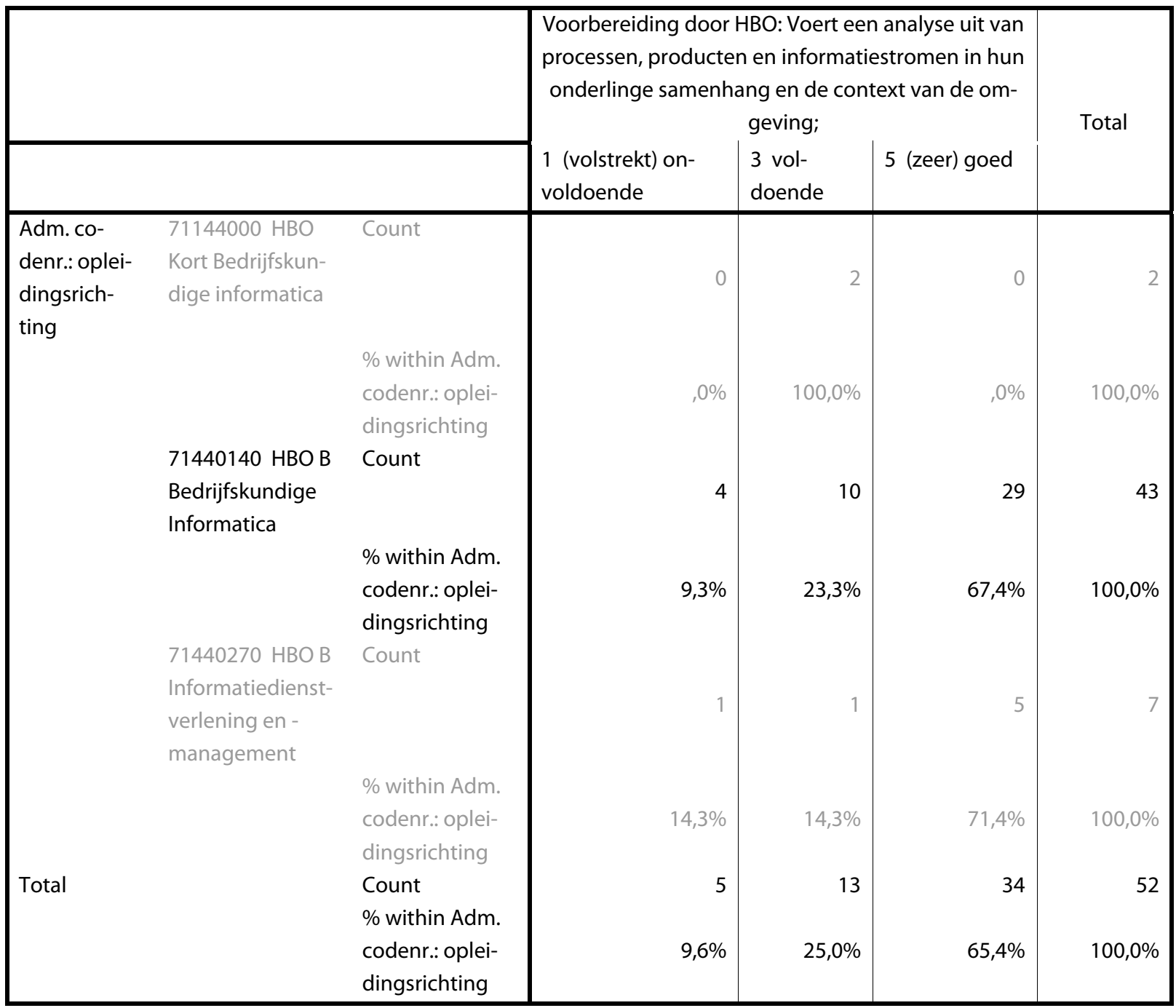


Adviseren m.b.t. processen, informatiestromen of ict-systemen

Formuleert op basis van een analyse en in overleg met stakeholders een onderbouwd advies voor de herinrichting van processen en/of informatiestromen en voor een nieuw te ontwikkelen of aan te schaffen ictsysteem. Betrekt hierin financiële aspecten, tijdsaspecten, de organisatie(verandering), haalbaarheid en risico's en mogelijkheden voor outsourcing

\begin{tabular}{|c|c|c|c|c|c|c|}
\hline & & & \multicolumn{3}{|c|}{$\begin{array}{l}\text { Voorbereiding door HBO: Formuleert op basis } \\
\text { van een analyse en in overleg met stakeholders } \\
\text { een onderbouwd advies voor de herinrichting } \\
\text { van processen en/of informatiestromen }\end{array}$} & \multirow[t]{2}{*}{ Total } \\
\hline & & & $\begin{array}{l}1 \text { (volstrekt) } \\
\text { onvoldoende }\end{array}$ & 3 voldoende & 5 (zeer)goed & \\
\hline $\begin{array}{l}\text { Adm. co- } \\
\text { denr.: oplei- } \\
\text { dingsrichting }\end{array}$ & $\begin{array}{l}71144000 \mathrm{HBO} \\
\text { Kort Bedrijfs- } \\
\text { kundige infor- } \\
\text { matica } \\
\text { 71440140 HBO } \\
\text { B Bedrijfskundi- } \\
\text { ge Informatica } \\
\text { B1440270 HBO } \\
\text { dienstverlening } \\
\text { en - } \\
\text { management }\end{array}$ & $\begin{array}{l}\text { Count } \\
\text { \% within Adm. } \\
\text { codenr.: oplei- } \\
\text { dingsrichting } \\
\text { Count } \\
\text { \% within Adm. } \\
\text { codenr.: oplei- } \\
\text { dingsrichting } \\
\text { Count } \\
\text { \% within Adm. } \\
\text { codenr.: oplei- } \\
\text { dingsrichting } \\
\text { Count } \\
\text { \% within Adm. } \\
\text { codenr.: oplei- } \\
\text { dingsrichting }\end{array}$ & $\begin{array}{r}1 \\
50,0 \% \\
4 \\
\\
9,1 \% \\
\\
\\
1 \\
14,3 \% \\
6 \\
11,3 \%\end{array}$ & $\begin{array}{r}31,8 \% \\
1 \\
1\end{array}$ & $\begin{array}{r}71,4 \% \\
32 \\
60,4 \%\end{array}$ & $\begin{array}{r}100,0 \% \\
44\end{array}$ \\
\hline
\end{tabular}




\section{Ontwerpen van ict-systemen}

Ontwerpt een ict-systeem op basis van een architectuurbeschrijving en specificaties, in samenhang met een analyse en binnen de gestelde kaders voor kwaliteit, testen, beveiliging, doorlooptijd, budget en exploitatie en beheer

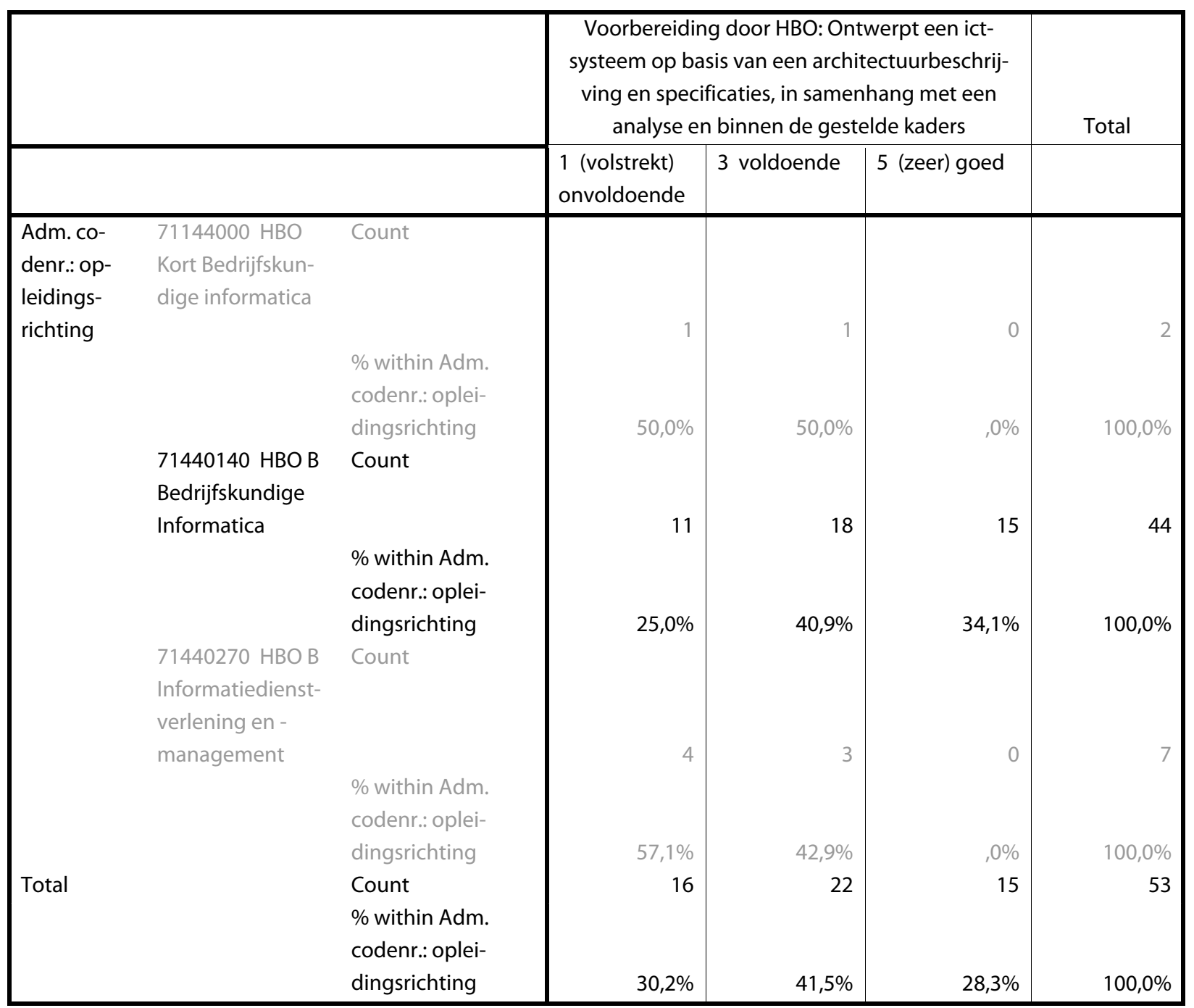




\section{Realiseren van ict-systemen}

Bouwt en implementeert een ict-systeem op basis van een functioneel en technisch ontwerp en binnen de gestelde kaders voor kwaliteit, testen, beveiliging, doorlooptijd, budget en exploitatie en beheer

\begin{tabular}{|c|c|c|c|c|c|c|}
\hline & & & \multicolumn{3}{|c|}{$\begin{array}{l}\text { Voorbereiding door HBO: Bouwt en imple- } \\
\text { menteert een ict-systeem op basis van een } \\
\text { functioneel en technisch ontwerp en bin- } \\
\text { nen de gestelde kaders voor kwaliteit, } \\
\text { testen, beveiliging, }\end{array}$} & \multirow[t]{2}{*}{ Total } \\
\hline & & & $\begin{array}{l}1 \text { (volstrekt) } \\
\text { onvoldoen- } \\
\text { de }\end{array}$ & 3 voldoende & $\begin{array}{l}5 \text { (zeer) } \\
\text { goed }\end{array}$ & \\
\hline $\begin{array}{l}\text { Adm. co- } \\
\text { denr.: oplei- } \\
\text { dingsrichting }\end{array}$ & $\begin{array}{l}71144000 \text { HBO } \\
\text { Kort Bedrijfskundi- } \\
\text { ge informatica } \\
71440140 \text { HBO B } \\
\text { Bedrijfskundige } \\
\text { Informatica } \\
\\
\text { 71440270 HBO B } \\
\text { Informatiedienst- } \\
\text { verlening en - } \\
\text { management }\end{array}$ & $\begin{array}{l}\text { Count } \\
\text { \% within Adm. } \\
\text { codenr.: oplei- } \\
\text { dingsrichting } \\
\text { Count } \\
\text { \% within Adm. } \\
\text { codenr.: oplei- } \\
\text { dingsrichting } \\
\text { Count } \\
\text { \% within Adm. } \\
\text { codenr.: oplei- } \\
\text { dingsrichting } \\
\text { Count } \\
\text { \% within Adm. } \\
\text { codenr.: oplei- } \\
\text { dingsrichting }\end{array}$ & $\begin{array}{r}1 \\
50,0 \% \\
18 \\
40,9 \% \\
\\
4 \\
47,1 \% \\
23 \\
43,4 \%\end{array}$ & $\begin{array}{r}45,5 \% \\
3 \\
\end{array}$ & $\begin{array}{r}13,6 \% \\
0 \\
\\
\\
\\
6 \\
6\end{array}$ & $\begin{array}{r}100,0 \% \\
7 \\
7\end{array}$ \\
\hline
\end{tabular}




\section{Beheren van ict-systemen}

Geeft vorm aan de exploitatie en het beheer van ict-systemen. Zorgt voor invoeren, testen, integreren en inbedrijfstelling van een nieuw(e release van een) ict-systeem. Verleent diensten die zijn overeengekomen (in een Service Level Agreement) binnen de gestelde kaders voor kwaliteit en financiën. Zorgt in samenhang met ontwerp en bouw voor het onderhoud van ict-systemen

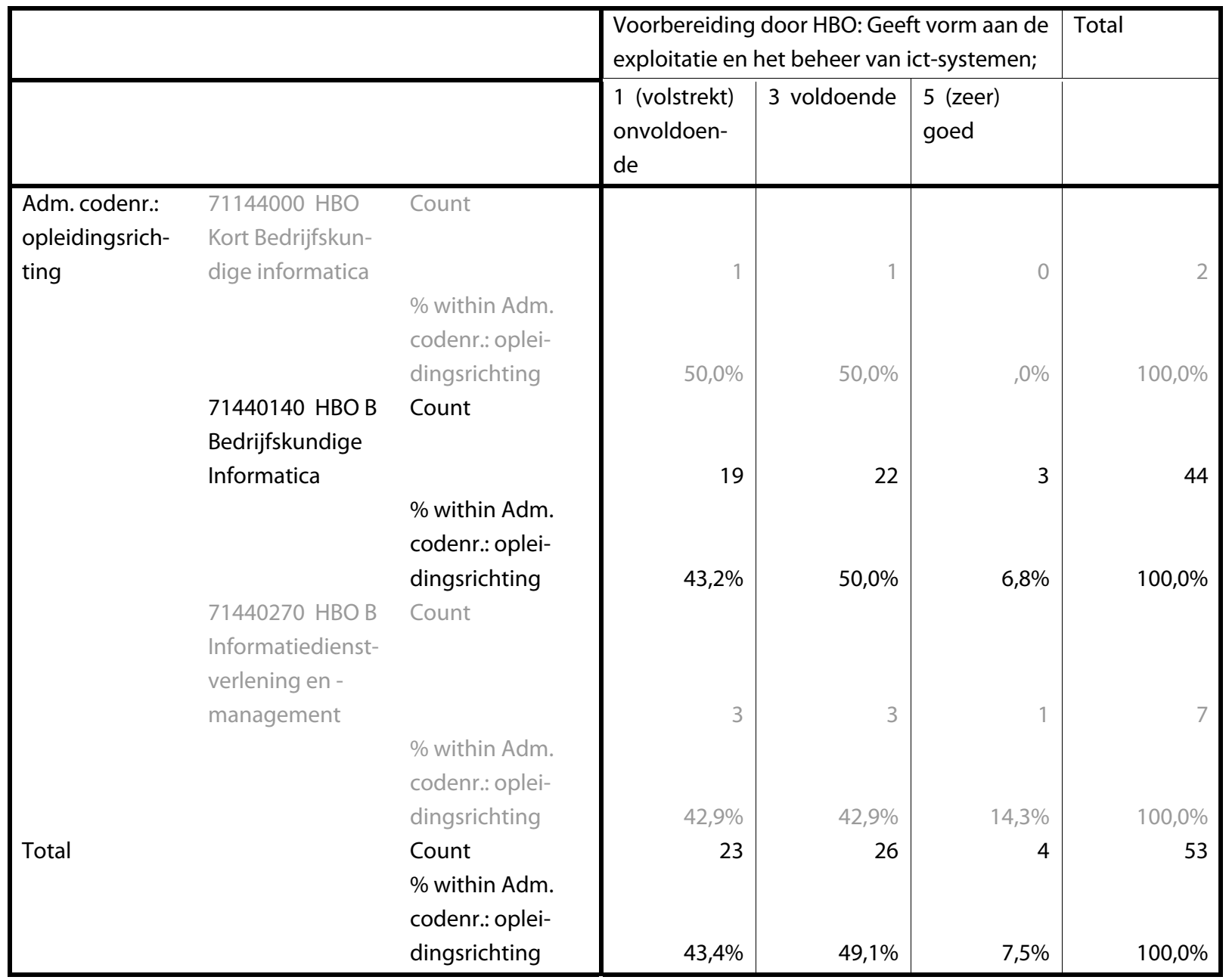

